\title{
Editor:
}

Dr. Adi Wijayanto, S.Or., S.Kom., M.Pd., AIFO. Prof. Dr. H. Akhyak, M.Ag. Santiana, S.S., M.Pd.

Dr. Sabaruddin Yunis Bangun, M.Pd

Dian Armada Pradana, S.Pd
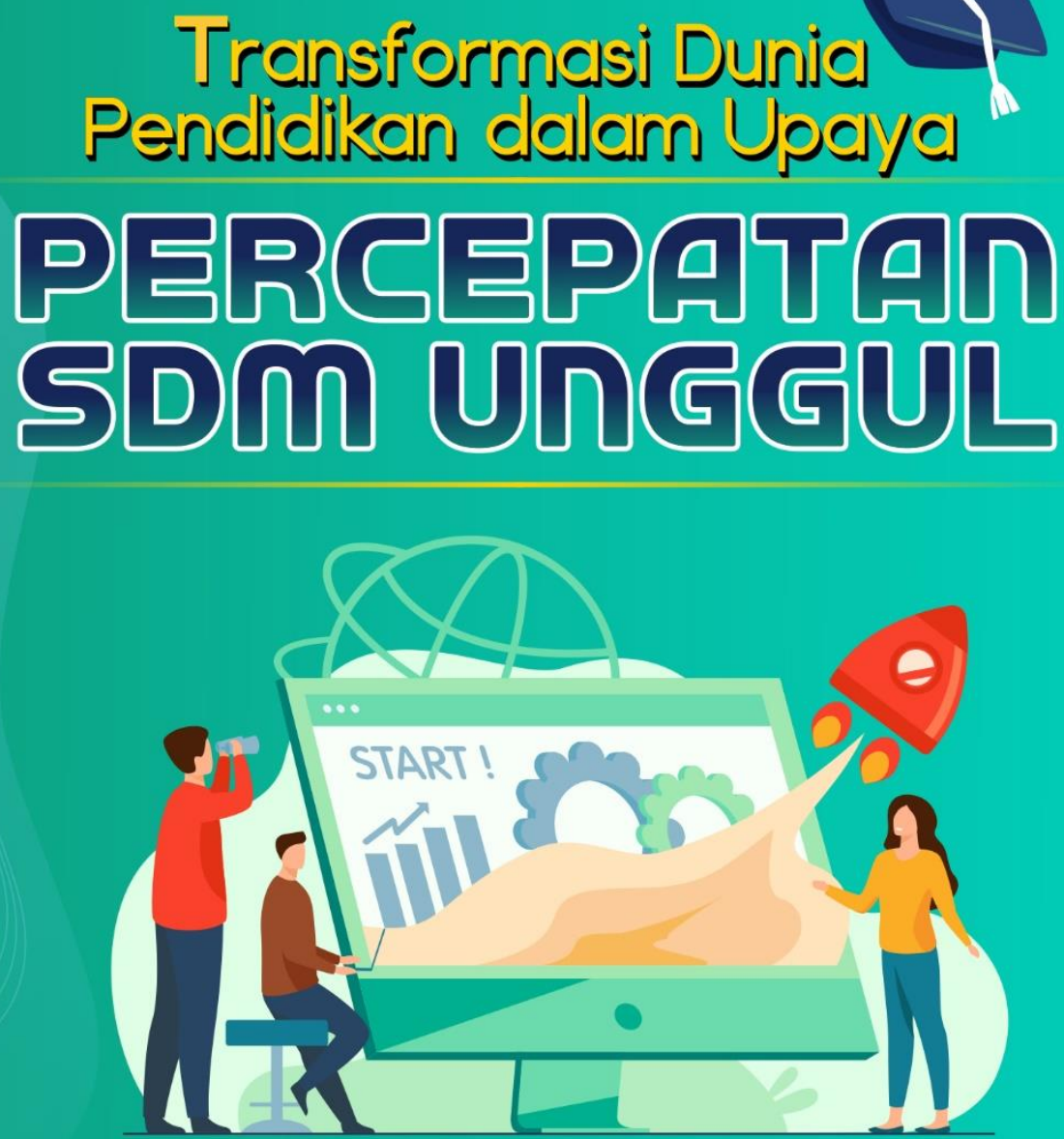

Rora Rizky Wandini | M. Rusdi Syawaludin | Maxsel Koro

Maria Angelina Fransiska Mbari | Evy Ramadina| Hermanu Iriawan Wara Sabon Dominikus | Yus Marlena | Silvi Aryanti | Jonni Siahaan Syarifuddin | Rif'iy Qomarrullah | Abdul Malik Iskandar

Tarisha Zetha Maharani | Muhammad Al Mansur | Rezza Ayatillah Velayati Joni Helandri | Khaerunnisa Tri Darmaningrum

Shinta Nurani Isatul Hasanah | Citra Resmi Nanda Putri Pratiwi |Ahmad Said Apriya Maharani Rustandi | Khalish Khairina | Supriadi | Marianus:Yufrinalis Bahagia | Ngimadudin | Filka Khairu Pratama | Welda Yulia | Syaiful Anwar 


\section{TRANSFORMASI DUNIA \\ PENDIDIKAN DALAM UPAYA PERCEPATAN SDM UNGGUL}

| Rora Rizky Wandini | M. Rusdi Syawaludin| Maxsel Koro |

|Maria Angelina Fransiska Mbari| | Evy Ramadina| |Hermanu Iriawan |Wara Sabon Dominikus| Yus Marlena|

|Silvi Aryanti| Jonni Siahaan | Syarifuddin|

|Rif'iy Qomarrullah| Abdul Malik Iskandar|

|Tarisha Zetha Maharani | Muhammad Al Mansur|

|Rezza Ayatillah Velayati | Joni Helandri |

| Khaerunnisa Tri Darmaningrum| Shinta Nurani| |Isatul Hasanah | Citra Resmi Nanda Putri Pratiwi| |Ahmad Said| Apriya Maharani Rustandi | Khalish Khairina|

|Supriadi| Marianus Yufrinalis| Bahagia | Ngimadudin|

|Filka Khairu Pratama| Welda Yulia| Syaiful Anwar|

\section{Editor:}

Dr. Adi Wijayanto, S.Or., S.Kom., M.Pd., AIFO.

Santiana, S.S., M.Pd.

Dr. Sabaruddin Yunis Bangun, M.Pd

Dian Armada Pradana, S.Pd

Kata Pengantar:

Prof. Dr. H. Akhyak, M.Ag. 


\section{TRANSFORMASI DUNIA PENDIDIKAN DALAM UPAYA PERCEPATAN SDM UNGGUL}

Copyright (C) Rora Rizky Wandini, dkk. 2021.

Hak cipta dilindungi undang-undang

All right reserved

Editor: Adi Wijayanto, dkk

Layout: Kowim Sabilillah

Desain cover: Diky M. Fauzi

v+ $167 \mathrm{hlm}$ : 14 x $21 \mathrm{~cm}$

Cetakan Pertama, September 2021

ISBN: 978-623-6364-33-8

\section{Anggota IKAPI}

Hak cipta dilindungi undang-undang. Dilarang mengutip atau

memperbanyak sebagian atau seluruh isi buku ini tanpa izin tertulis dari penerbit.

Diterbitkan oleh:

\section{Akademia Pustaka}

Perum. BMW Madani Kavling 16, Tulungagung

Telp: 081216178398

Email: redaksi.akademia.pustaka@gmail.com

Website: www.akademiapustaka.com 


\section{KATA PENGANTAR}

Alhamdulillahi Rabbilalamin kehadirat Allah SWT yang September tahun 2021 yang berjudul "Transformasi dunia Pendidikan dalam upaya percepatan SDM Unggul" dapat diselesaikan dengan sebaik-baiknya atas sumbangsih ide atau gagasan dan pemikiran dari para pakar pendidikan dan stake holder.

Tidak dapat dipungkiri bahwa COVID-19 membawa kita ke dalam era VUCA (volatility, uncertainty, complexity, ambiguity). VUCA adalah sebuah kondisi dimana terjadi perubahan cepat (Volatile) yang penuh ketidakpastian (Uncertainty), dengan segala permasalahan yang kompleks (Complexity), hingga pada akhirnya membuat semua pihak ragu mengambil keputusan (Ambiguity).

Banyak riset menunjukkan bahwa kunci bertahan hidup dalam era VUCA ini adalah memiliki sikap adaptif dan kolaboratif. Setiap lapisan sosial, mulai dari individu hingga negara, harus dapat menyesuaikan diri terhadap perubahan serta mampu melibatkan kolaborasi berbagai sektor untuk mendapatkan solusi yang pendekatan berpusat pada manusia. Salah satu kolaborasi yang memegang peranan penting dalam penanganan COVID-19 adalah antara pemerintah dengan para peneliti dan akademisi.

Karenanya, bunga rampai "Transformasi dunia Pendidikan dalam upaya percepatan SDM Unggul" yang berisi karya tulis ilmiah dari peneliti ini merupakan suatu masukan yang sangat berharga bagi negara, khususnya pemerintah. Buku ini dibagi dalam tujuh bab yang 
diantaranya membedah kebijakan COVID-19 pada ranah pendidikan

Kehadiran buku bunga rampai ini dapat menjadi salah satu inspirasi bagi akademisi dan peneliti lainnya untuk terus menyoroti dampak COVID-19 dan dinamika yang terjadi di lapangan. Semoga karya tulis ini dapat menjadi pemantik bagi para akademisi dan peneliti untuk menerbitkan publikasi yang sangat bermanfaat bagi masyarakat luas.

Tulungagung, 11 September 2021

Prof. Dr. H. Akhyak, M.Ag.

Direktur Pascasarjana UIN SATU 


\section{DAFTAR ISI}

KATA PENGANTAR

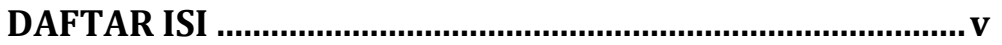

BAB I

PENINGKATAN PADA DUNIA PENDIDIKAN

MENDIAGNOSA SISWA UNTUK MENCIPTAKAN

SDM UNGGUL

Oleh Rora Rizky Wandini .3

PENTINGNYA EVALUASI PENDIDIKAN

DI ERA NEW NORMAL

Oleh M. Rusdi Syawaludin

.9

SELF-REGULATED LEARNING SEBAGAI STRATEGI

BELAJAR SISWA SD DI MASA PANDEMI COVID-19

Oleh Maxsel Koro

ASESSMENT VIRTUAL PADA PEMBELAJARAN SEKOLAH

DASAR DI MASA PANDEMI COVID-19

Oleh Maria Angelina Fransiska Mbari.

ASESMEN FORMATIF UNTUK MENGETAHUI

CAPAIAN BELAJAR MURID

Oleh Evy Ramadina.

TRANSFORMASI PENDIDIKAN TINGGI DI ERA MERDEKA BELAJAR KAMPUS MERDEKA

Oleh Hermanu Iriawan

COVID 19 DAN DISRUPSI PENDIDIKAN

Oleh Wara Sabon Dominikus 43

PRESTASI SISWA MAN 1 GROBOGAN DI MASA PANDEMI

Oleh Yus Marlena 51 
MOTIVASI BELAJAR MAHASISWA PADA

MASA PANDEMI COVID-19

Oleh Silvi Aryanti 63

BAB II

PENINGKATAN KEMAMPUAN SUMBER DAYA

COVID-19 DI ERA DIGITAL SEBAGAI JEMBATAN

MELONCAT MEWUJUDKAN KOMPETENSI

Oleh Jonni Siahaan.

MEMBANGUN SUMBER DAYA MANUSIA (SDM) UNGGUL DENGAN PENGEMBANGAN PENDIDIKAN

DI TENGAH PANDEMI COVID-19

Oleh Syarifuddin 79

OPTIMISME DAN PESIMISME MEMBANGUN SDM UNGGUL DI KONDISI PANDEMI COVID-19

Oleh Rifiy Qomarrullah 85

ADAPTASI PEMBELAJARAN TERHADAP BERGESERNYA KELAS OFFLINE KE ONLINE DI MASA PANDEMI COVID-19 Oleh Abdul Malik Iskandar. 93

SUMBER DAYA MANUSIA UNGGUL PADA SAAT PANDEMI "PENDIDIKAN DI ERA PANDEMI COVID-19"

Oleh Tarisha Zetha Maharani. 103

PERAN KELUARGA DALAM MENCIPTAKAN SDM UNGGUL DI MASA PANDEMI COVID-19

Oleh Muhammad Al Mansur. 109

HIGHLIGHTING HUMAN RESOURCES (TEACHER)

PERFORMANCE IN THE MIDST OF PANDEMIC COVID 19

Oleh Rezza Ayatillah Velayati. 
TEKNIK DICSTOM, TRIAL WEB DESIGN, DAN

ENGAGEMENT STRATEGY, SEBAGAI METODE ALTERNATIF MENINGKATKAN KEMAMPUAN MAHASISWA MENULIS TEKS SEJARAH ISLAM MENGGUNAKAN BAHASA INGGRIS

SELAMA PANDEMI COVID-19

Oleh Joni Helandri

PERAN IBU TUNGGAL DALAM MENJAGA KETAHANAN KELUARGA PADA MASA PANDEMI

Oleh Khaerunnisa Tri Darmaningrum

MEMBUMIKAN NALAR TEOLOGIS MASYARAKAT

RELIGIUS DI ERA PANDEMI

Oleh Shinta Nurani

URGENSI KEAKTIFAN SISWA DALAM MEWUJUDKAN GENERASI YANG UNGGUL DI TENGAH

PANDEMI COVID-19

Oleh Isatul Hasanah

BAB III

KEBIJAKAN DAN REGULASI SAAT PANDEMI

IMPLEMENTASI PERAN PEMERINTAH KOTA TEGAL TERHADAP KEBIJAKAN PERCEPATAN VAKSIN COVID-19

Oleh Citra Resmi Nanda Putri Pratiwi.

POLITICAL WILL UNTUK MEMBANGUN MANUSIA UNGGUL MELALUI UU CIPTA KERJA SAAT PANDEMI Oleh Ahmad Said 167

ANALISIS FENOMENA PEMBELAJARAN DARING MELALUI KEBIJAKAN PENDIDIKAN PADA MASA DARURAT PENYEBARAN CORONA VIRUS DISEASE (COVID 19) Oleh Apriya Maharani Rustandi 173 
SOLUSI MENGATASI BADAI PENGANGGURAN

DI MASA PANDEMI COVID 19

Oleh Khalish Khairina.

JURNALISME KEMANUSIAAN PADA MASA

PANDEMI COVID-19

Oleh Supriadi 189

MELAWAN STIGMA SOSIAL AKIBAT PANDEMI COVID-19

Oleh Marianus Yufrinalis.

KEBIJAKAN TETAP BEKERJA DARI RUMAH (WORK FROM HOME) DI MASA COVID- 19 DI KANTOR WILAYAH KEMENTERIAN AGAMA PROVINSI ACEH

(Implementasi Surat Edaran Kementerian Agama Nomor SE.14 Tahun 2021 Tentang Sistem Kerja Aparatur Sipil Negara (ASN) Pada masa Pandemi Covid -19 Tahun kedua)

Oleh Bahagia .203

KEMANDIRIAN PENYELENGGARA PEMILIHAN PADA MASA PANDEMI COVID-19

Oleh Ngimadudin

VAKSINASI DIBUTUHKAN \& AMAN UNTUK KELUARGA

Oleh Filka Khairu Pratama

CYBERSPACE DALAM KOMUNIKASI KESEHATAN

DI ERA PANDEMI

Oleh Welda Yulia .225

HUKUM DAN KEMANUSIAAN

DI MASA PANDEMI COVID-19

Oleh Syaiful Anwar .237 


\section{BAB I}

\section{PENINGKATAN PADA DUNIA PENDIDIKAN}

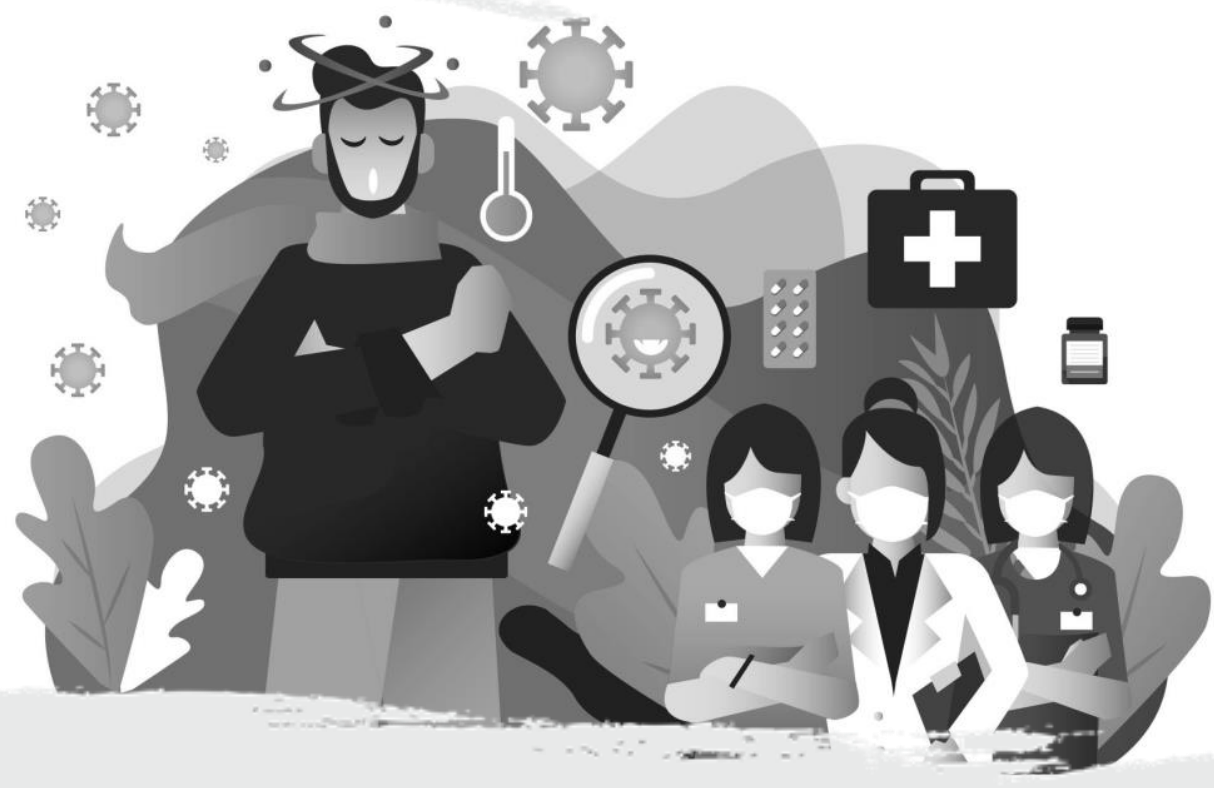




\section{MENDIAGNOSA SISWA UNTUK MENCIPTAKAN SDM UNGGUL}

\section{Rora Rizky Wandini ${ }^{1}$ \\ Universitas Islam Negeri Sumatera Utara Medan}

"Mencetak sumber daya manusia yang unggul harus memperhatikan kesiapan peserta didik sehingga perlu adanya diagnosa dalam setiap pembelajaran"

Indonesia ditahun 2020-2021 ini terus dilanda dengan ketakutakan pemaparan wabah penyakit, yang identitasnya kita kenal dengan COVID 19. Dampak dari wabah ini menyerang seluruh sektor, baik sektor ekonomi, kebudayaan, dan khususnya pada sektor pendidikan. Kebijakan pemerintah memberikan solusi untuk pendidikan dengan pengadaan pembelajaran daring. Untuk mendukung pembelajaran daring tersebut pemerintah memberikan subsidi kuota bagi para pendidik maupun peserta didik. Namun subsidi kuota tersebut dirasakan tidak terlalu cukup untuk mendukung kegiatan pembelajaran yang disajikan dengan program daring. Banyak sekolah swasta yang mengambil kebijakan sendiri dengan membuat sistem sift yaitu membagi siswa berdasarkan kuota kelas dengan masuk tatap muka menggunakan durasi waktu 2 jam

1Penulis lahir pada tanggal 25 September 1990. Penulis merupakan Dosen UIN Sumatera Utara Medan dalam bidang Pendidikan Guru Madrasah Ibtidaiyah. Penulis menyelesaikan gelar pendidikan Sarjana PGMI di IAIN Medan, gelar Magister PGMI di UIN Maulana Malik Ibrahim Malang, dan gelar Doktor Pendidikan Dasar Islam di UIN Sumatera Utara Medan. 
pembelajaran selama satu hari, dan untuk mengelabui peraturan pemerintah kebijakan penggunaan baju seragampun ditiadakan. Sekolah berani mengambil kebijakan seperti itu karena banyaknya tuntutan orang tua yang kuawalahan mengajarkan, mendampingi anaknya dalam penyelesaian tugas-tugas yang diberikan, selain itu banyaknya fenomena badut musik yang turun kejalanan yang notabene dilakukan oleh anak-anak usia sekolah dasar dan sekolah menengah pertama, serta pengamen jalanan dan pelayan-pelayan toko, cafe, serta minimarket yang diisi oleh anak-anak usia sekolah menengah atas dan bahkan mahasiswa. Keadaan yang demikian tidak bisa dibiarkan begitu saja, karena akan berbahaya untuk kondisi mental peserta didik secara khusus. Maka peran guru sangat berpengaruh untuk mengembalikan kondisi seperti ini kembali seperti semula sebelum covid melanda Indonesia. Walaupun pembelajaran dilakukan secara daring maupun dilakukan secara luring.

Untuk persiapan pembelajaran guru harus mendiagnosa setiap siswanya sebelum mengikuti pembelajaran. Pendiagnosaan tersebut bertujuan untuk mengetahui kesiapan siswa dalam mengikuti kegiatan pembelajaran, selain itu juga bertujuan untuk mengidentifikasi materi apa saja yang sudah dikuasai dan dipahami siswa. Sehingga ketika siswa sudah siap untuk belajar secara otomatis akan menerima pembelajaran dengan baik, dan siswa juga akan lebih mudah memahami materi yang diajarkan. Pendiagnosaan tersebut dapat dilakukan guru pada awal siswa masuk kedalam sekolah, atau pada awal pembelajaran, dan mungkin juga ditengah bahkan di akhir pembelajaran, serta dapat dilakukan selama satu semester, pertengahan semester atau bahkan 
perminggu. Adapun cara yang dapat dilakukan guru dalam mendiagnosa siswanya dengan memanfaatkan sebuah tes, baik tes lisan maupun tes tulisan. Pendiagnosaan siswa tersebut dinamakan penilaian diagnostik atau assesment diagnostik. Jadi penilaian/ assesment diagnostik ini memiliki pengertian yang penilaian yang dilakukan untuk mendiagnosa siswa sebelum mengikuti pembelajaran. Penilaian diagnostik ini dapat dilakukan guru dengan beberapa tahapan. Adapun tahapannya sebagai berikut:

1. Guru harus melakukan persiapan

Dalam melakukan persiapan seorang guru harus membuat list atau draft pribadi, yang difungsikan untuk memberi pengingat pada guru bahwa ia telah melakukan penilaian diagnostik, serta untuk menjaga tidak terjadi dua kali penilaian dengan materi yang sama. Dalam hal ini penulis mencontohkan list yang dapat dibuat oleh guru (lihat tabel 1.1). untuk contoh list yang dimaksud hal itu bukanlah contoh yang baku, masih dapat dikembangkan lagi sesuai dengan kebutuhan bapak ibu guru, serta sesuai dengan kondisi sekolah bapak ibu guru masing-masing. Adapun contoh listnya sebagai berikut:

Tabel 1.1 List persiapan awal:

\begin{tabular}{|l|l|}
\hline \multicolumn{1}{|c|}{ Ceklist } & \multicolumn{1}{c|}{ Keterangan } \\
\hline $\begin{array}{l}\text { Untuk kelas berapa penilaian } \\
\text { diagnostik ini dibuat }\end{array}$ & Misal: kelas 6 SD \\
\hline $\begin{array}{l}\text { Kapan waktu pelaksanaan } \\
\text { penilaian diagnostik ini dilakukan }\end{array}$ & Awal semester \\
\hline $\begin{array}{l}\text { Dalam bentuk apa penilaian } \\
\text { diagnostik ini dilakukan }\end{array}$ & Tes tulis pilihan berganda \\
\hline $\begin{array}{l}\text { Dimana Penilaian dignostik ini } \\
\text { dilakukan }\end{array}$ & $\begin{array}{l}\text { Disekolah, dirumah, atau dalam } \\
\text { jaringan }\end{array}$ \\
\hline
\end{tabular}




\begin{tabular}{|l|l|}
\hline $\begin{array}{l}\text { Mata pelajaran apa yang akan } \\
\text { dilakukan penilaian diagnostik. }\end{array}$ & Matematika \\
\hline $\begin{array}{l}\text { Materi apa yang akan dilakukan } \\
\text { penilaian diagnostik tersebut }\end{array}$ & $\begin{array}{l}\text { Giometri, pecahan senilaian dan } \\
\text { Volume }\end{array}$ \\
\hline
\end{tabular}

2. Mengidentifikasi materi yang akan dijadikan penilaian diagnostic

Setelah guru membuat list atau draf pribadi untuk memulai perlakuan dalam penilaian diagnostik ini, langkah selanjutnya yang dapat dilakukan guru yaitu melakukan identifikasi materi yang akan diangkat. Pengidentifikasian materi ini dapat dipilih melalui penelusuran kompetensi dasar (KD) yang telah ditentukan pemerintah, dan biasanya letak kompetensi dasar tersbut terletak di buku guru. Pemilihan materi ini juga memiliki aturan diantaranya dalam memilih materi dapat memilih KD di bawah semester yang berlangsung, atau KD saat semester berlangsung maupun KD sesudah semester berlangsung, atau KD sebelum pembelajaran, KD saat pembelajaran, maupun KD setelah pembelajaran. Untuk memahami pengidentifikasian materi ini dapat dilihat pada tabel berikut:

Tabel 1.2 Identifikasi materi melalui KD

\begin{tabular}{|c|c|c|}
\hline KD-1 & KD-2 & KD-3 \\
\hline $\begin{array}{l}\text { 4.2 Menyelesaikan } \\
\text { masalah yang berkaitan } \\
\text { dengan perkalian dan } \\
\text { pembagian pecahan dan } \\
\text { desimal }\end{array}$ & $\begin{array}{l}\text { 3.6 Menjelaskan dan } \\
\text { menemukan jaring- } \\
\text { jaring bangun ruang } \\
\text { sederhana (kubus } \\
\text { dan balok) }\end{array}$ & $\begin{array}{l}4.6 \text { Membuat } \\
\text { jaring-jaring } \\
\text { bangun ruang } \\
\text { sederhana } \\
\text { (kubus dan } \\
\text { balok) }\end{array}$ \\
\hline
\end{tabular}

Setelah mengidentifikasi KD hal berikutnya yang dilakukan adalah membuat soal berdasarkan KD-1, KD-2, KD-3 tersebut. Soal yang dibuat dapat berupa pilihan berganda, essai, isian, soal berpasangan dan lain-lain. Adapun klsifikasi contoh soal sebagai berikut: 
Tabel 1.3 simulasi soal yang digunakan dalam penilaian diagnostik

\begin{tabular}{|clc|}
\hline \hline NO SOAL & \multicolumn{1}{c|}{ PERTANYAAN } & BENTUK SOAL \\
\hline 1 & Siti memakan satu potong kue seperti pada gambar. Nilai pecahan dari bagian kue yang dimakan Siti adalah ..... & PJ \\
2 & Lingkarilah sendok-sendok di atas agar mendapatkan nilai pecahan $1 / 3$ & Isian \\
3 & Tuliskan urutan pecahan yang benar dari $1 / 2,1 / 3$, dan $1 / 4$ pada garis bilangan di atas & Isian \\
4 & Berapakah hasil dari $27 \times 3$ & Isian \\
5 & Sebanyak 30 siswa dibagi menjadi 5 kelompok sama banyak. Berapakah jumlah siswa dalam satu kelompok & Uraian \\
6 & Perhatikan gambar di samping! Tinggi lemari adalah ... meter & PJ \\
7 & lbu membeli wortel 1 kg dan cabai 3 ons. Berat belanjaan lbu adalah .... gram & Uraian \\
8 & Persegi adalah persegi panjang & BS \\
9 & Selisih banyak siswa yang memperoleh nilai tertinggi dan terendah adalah 2 orang & BS \\
10 & Tarik garis untuk memasangkan sudut-sudut berikut dengan jenis sudutnya & Menjodohkan \\
\hline
\end{tabular}

Dokumentasi soal tanoto foundation.

3. Mendiagnosa dan melakukan tindak lanjut

Setelah membuat identifikasi materi maka tindakan selanjutnya adalah menyebarkan soal-soal tersebut kepada siswa untuk mengetahui hasil diagnosanya dan menentukan tindakan selanjutnya. Pendiagnosaan hasil jawaban soal yang diberikan dapat dilakukan guru dengan menggunakan bantuan aplikasi microsofe exel, yaitu menggunakan skla "1" dan "0". Jika siswa berhasil menjawab soal dengan benar maka nilai yang diperolehnya adalah "1" poin dan jika siswa menjawab soal dengan salah maka siswa memperoleh poin "0". Dan setiap jawaban siswa diberi kode "P" (Paham Utuh), "PS" (Paham sebagian), "TP (Tidak paham)”. Pengkodean ini dimaksudkan untuk memberi kemudahan pada guru dalam mengidentifikasi siswa yang paham, paham sebagian dan tidak paham. Bagi siswa yang teridentifikasi dengan kode paham utuh maka guru dapat memberi tindaklanjut dengan pendalaman materi, atau siswa tersebut berhak untuk mengikuti materi selanjutnya, sedangkan siswa yang dengan kategori paham sebagian, akan mendapat pengayaan atau pengulangan materi terhadap materi yang tidak 
dipahaminya, dan bagi siswa dengan kategori tidak paham, akan mendapatkan perlakuan remedial atau dititipkan pada kelas dibawahnya. Dengan pemberlakuan pengkodean ini maka tidak ada siswa yang dirugikan. Pelayanan yang diberikan guru sesuai dengan kebutuhan siswanya. Maka tidak ada lagi lebel siswa pintar, pintar sekali, atau siswa bodoh, bodoh sekali. Semua perlakuan disesuaikan dengan kebutuhan siswa tersebut.

Setelah bapak ibu guru mengetahui tahapan penilaian diagnistik, maka bapak ibu guru juga harus tau apa prinsip dari penilaian tersebut. Karena tanpa prinsip ini bapak ibu akan sembrono dalam melakukan penilaian. Adapun prinsip penilaian diagnostik yang wajib diketahui yaitu: 1 . Valid, 2. Reliabel, 3. Adil, 4. Fleksibel, 5. Otentik, 6. Terintegrasi. Untuk lebih jelasnya dapat dilihat pada tabel berikut:

\begin{tabular}{|l|l|}
\hline Valid & $\begin{array}{l}\text { Menghasilkan informasi yang sahih mengenai } \\
\text { pencapaian dari siswa }\end{array}$ \\
\hline Reliabel & $\begin{array}{l}\text { Menghasilkan informasi yang konsisten serta } \\
\text { dapat dipercaya mengenai pencapaian siswa }\end{array}$ \\
\hline Adil & $\begin{array}{l}\text { Dilaksanakan dengan tidak merugikan } \\
\text { terhadap kondisi siswa }\end{array}$ \\
\hline Fleksibel & $\begin{array}{l}\text { Dilaksanakan sesuai dengan kondisi dan } \\
\text { kebutuhan siswa dan Satuan Pendidikan }\end{array}$ \\
\hline Otentik & $\begin{array}{l}\text { Fokus dalam capaian belajar siswa pada } \\
\text { konteks penyelesaian masalah di kehidupan } \\
\text { sehari-hari }\end{array}$ \\
\hline Adil & $\begin{array}{l}\text { Dilaksanakan sebagai bagian integral dari } \\
\text { pembelajaran, sehingga menghasilkan umpan } \\
\text { balik yang berguna untuk memperbaiki proses } \\
\text { dan hasil belajar siswa }\end{array}$ \\
\hline
\end{tabular}




\title{
PENTINGNYA EVALUASI PENDIDIKAN DI ERA NEW NORMAL
}

\author{
M. Rusdi Syawaludin, M.Si ${ }^{2}$
}

STAIN Bengkalis

"Menerapkan evaluasi dalam pendidikan di era new normal merupakan usaha guru yang harus dilaksanakan secara kontinu untuk memperbaiki dan meningkatkan kualitas pembelajaran"

Evaluasi dalam pendidikan merupakan suatu proses
untuk mengumpulkan, menginterprestasi dan menganalisa informasi agar dapat mengetahui tingkat pencapaian tujuan pembelajaran oleh siswa. Apabila sistem evaluasi dilakukan dengan baik maka dapat memberikan gambaran mengenai kualitas pembelajaran yang dilakukan sehingga dapat membantu guru untuk merencanakan strategi dan metode pembelajaran yang lebih baik.

Terutama pada era new normal ini, pembelajaran yang menarik dan sesuai dengan kebutuhan siswa sangat perlu dipersiapkan. Siswa yang mulai asik dengan dunia gadget membuat mereka lebih focus ke social media, bermain game dan sebagainya, dibandingkan dengan melihat materi

2Penulis lahir di Pekanbaru, 15 Maret 1994. Penulis merupakan Dosen STAIN Bengkalis dalam bidang ilmu Penelitian dan Evaluasi Pendidikan. Penulis menyelesaikan gelar Sarjana Ilmu Pendidikan di Universitas Islam Riau, Program Studi Pendidikan Matematika (2016), dan gelar Magister Sains diselesaikan di Universitas Riau Program Studi Matematika (2019). 
pelajaran dan mengerjakan tugas yang diberikan. Cara mengajar, pendekatan ke masing-masing siswa yang menyenangkan perlu di pertimbangkan.

Agar kualitas pendidikan tetap meningkat maka perlu dilakukan evaluasi yang benar-benar baik dan tersusun rapi, dalam melakukan evaluasi sebaiknya memperhatikan beberapa prinsip yaitu keterpaduan, keterlibatan siswa, koherensi, pedagogis dan akuntabilitas.

\section{Keterpaduan}

Materi, metode pengajaran, tujuan instruksional, serta evaluasi merupakan tiga kesatuan terpadu yang tidak dapat dipisahkan. Sehingga, perencanaan evaluasi seharusnya sudah ditetapkan pada saat menyusun perangkat pembelajaran sehingga dapat disesuaikan dengan tujuan intruksional dan materi yang ingin disajikan.

\section{Keterlibatan Siswa}

Untuk mengukur tingkat keberhasilan siswa dalam proses belajar mengajar maka siswa membutuhkan suatu evaluasi. Seorang guru harus menyediakan evaluasi untuk memenuhi kebutuhan siswa sebagai bentuk pengukuran kemajuan dalam program belajar mengajar. Seorang siswa akan merasa kecewa apabila hasil dari belajarnya tidak di evaluasi.

\section{Koherensi}

Evaluasi yang dibuat dan dilakukan haruslah berkaitan dengan materi pengajaran yang sudah dipelajari oleh siswa, dan disesuaikan dengan ranah kemampuan yang ingin di nilai.

4. Pedagogis 
Evaluasi dan hasil yang dilakukan sebaiknya digunakan sebagai alat untuk motivasi siswa dalam pembelajaran selanjutnya.

\section{Akuntabilitas}

Evaluasi dan hasil yang dilakukan dapat di gunakan sebagai laporan kepada pihak yang berkepentingan dalam pendidikan sehingga dapat di ukur sejauh mana keberhasilan belajar mengajar yang telah dilakukan.

\section{Kontinuitas}

Evaluasi dalam pendidikan tidak dilakukan hanya sekali, namun guru harus terus melakukan evaluasi ini secara berkesinambungan agar terus dapat memantau perkembangan masing-masing siswa dan pelaporannya pun dapat dipantau secara kontinu.

\section{Komprehensif}

Evaluasi yang dilakukan tidak boleh hanya berfokus pada aspek kognitif namun juga perlu memerhatikan aspek afektif yang juga berperan besar dalam proses pembelajaran.

\section{Kooperatif}

Evaluasi dilakukan harus berkoordinasi dengan segala bidang yang berkaitan, mulai dari kepala sekolah, guru mata pelajaran, wali kelas, orang tua serta petugas administrasi.

9. Objektif

Penilaian untuk hasil harus berisifar objektif, artinya segala factor yang mengandung subyektif seperti adanya hubungan internal guru dengan siswa atau merasa tidak tega maupun yang lainnya tidak boleh dimasukkan kedalam evaluasi. 


\section{Praktis}

Setiap evaluasi juga harus bersifat praktis. Artinya, kegiatan evaluasi harus dapat menghemat biaya, tenaga dan waktu. Namun harus diperhatikan agar tidak menghilangkan esensi dari evaluasi itu sendiri.

Dalam merencanakan evaluasi, seorang guru hendaknya selalu memperhatikan dan berpegang pada prinsip tersebut. Hal ini ditujukan agar guru dapat bertindak dan berusaha seobjektif mungkin dalam melakukan evaluasi. Evaluasi sebagai proses pendidikan memiliki beberapa fungsi yaitu sebagai berikut:

1. Sebagai umpan balik (feed back) untuk memperbaiki proses belajar

2. Sebagai penentu angka kemampuan/hasil dari belajar

3. Sebagai penentu metode yang baik digunakan untuk setiap siswa

4. Sebagai pengenal latar siswa yang mengalami kesulitan dalam belajar

Era pandemi telah memberikan dampak terhadap dunia pendidikan di Indonesia. Pada enam bulan masa darurat pandemi COVID-19 pembelajaran di semua level pendidikan dilaksanakan secara daring. Namun, di masa new normal ini, ada beberapa sekolah ataupun perguruan tinggi yang melaksanakan pembelajaran secara online dengan menggunakan segala aplikasi daring dan juga di selingi dengan pembelajaran tatap muka, walaupun hanya dua atau tiga hari dalam seminggu dan tetap melaksanakan protokol kesehatan yang berlaku.

Proses peralihan pembelajaran daring menuju pembelajaran tatap muka ini membuat siswa tidak bersemangat dalam mengikuti pembelajaran tatap muka 
dikarenakan mereka sudah merasa senang dengan belajar secara daring. Jika dalam pembelajaran online mereka bisa belajar sambil bermain di luar, tidur lebih lama tanpa ditegur oleh guru, namun pada saat pembelajaran tatap muka, kelas tidak dapat di tinggalkan serta anak-anak langsung diawasi oleh guru. Selain itu anak-anak juga tidak siap menerima materi yang banyak, dapat dilihat dari banyaknya yang tidak memperhatikan pembelajaran. Dalam hal ini guru harus bisa menganalisis cara belajar dan membuat metode pembelajaran yang tepat dan menyenangkan agar mereka bisa semangat kembali untuk mengikuti proses pembelajaran tatap muka.

Oleh karena itu, evaluasi dalam pendidikan merupakan komponen yang sangat penting dalam proses belajar mengajar. Ketika proses belajar mengajar dipandang sebagai proses mendidik dan langkah untuk merubah prilaku dan sikap siswa, peran evaluasi pembelajaran menjadi sangat penting.

Seorang guru harus mengetahui cara mengevaluasi yang baik, apabila guru tidak memahami evaluasi tersebut maka akan berakibat melemahnya moral seorang guru. Salah satu kenyataan yang terjadi pada era new normal ini adalah banyaknya kecurangan dengan memanipulasi nilai raport siswa, dengan tujuan agar predikat sekolah selalu berkualitas baik. Padahal guru pun tidak tahu kemampuan yang ada dalam masing-masing siswa tersebut.

Pemberian nilai yang tidak sesuai dengan kemampuan siswa berakibat pada rasa puas dan niat belajar pada siswa. Semakin tinggi rasa puas pada siswa dalam belajar maka semakin tinggi keinginan siswa untuk belajar lebih baik lagi. Namun nilai yang diberikan tidak diperoleh dari evaluasi yang baik maka semakin melemah rasa puas siswa, mereka 
beranggapan bahwa untuk mendapatkan nilai yang bagus tidak perlu lagi belajar giat dan semakin lama merekapun semakin malas untuk belajar.

Kecendrungan sekolah ingin memperoleh nama yang baik, predikat yang bagus dengan cara curang atau tidak sesuai dengan prosedur di dalam dunia pendidikan perlu diperhatikan lagi. Percuma menyandang perdikat yang bagus tapi output yang dihasilkan kurang bermutu. Lebih baik memberikan nilai apa adanya sesuai dengan kemampuan siswa, daripada memberikan nilai yang tidak sesuai dengan kemampuan siswa, karena dampak yang akan timbul dari manipulasi jauh lebih buruk.

Berdasarkan paparan diatas evaluasi pendidikan sangat penting dilakukan agar merubah pola pikir siswa dan guru, sehingga dapat menghasilkan generasi yang jauh lebih baik. Apabila evaluasi dilakukan dengan bagus secara kontiniu, tidak hanya siswa, guru dan sekolah pun akan menjadi sarana pendidikan yang menunjang kemajuan negara Indonesia di era new normal. 


\title{
SELF-REGULATED LEARNING SEBAGAI STRATEGI BELAJAR SISWA SD DI MASA PANDEMI COVID-19
}

\author{
Maxsel Koro,S.Pd.,M.Pd ${ }^{3}$ \\ Universitas Nusa Cendana Kupang
}

“Wabah pandemi covid-19 yang memberikan pengaruh besar terhadap sistem pendidikan di Indonesia menjadi problematika yang harus dipecahkan supaya pembelajaran tetap berjalan optimal melalui strategi self regulated learning"

Pandemi Covid-19 yang saat ini merambah memaksa masyarakat untuk merubah pola kehidupannya, dimana masyarakat dibatasi dalam interaksi sosialnya. Pembatasanpembatasan tersebut membawa dampak juga pada pola pembelajaran di sekolah, dimana saat ini sekolah dituntut untuk melakukan pembelajaran secara daring. Hal ini tentunya membawa berbagai masalah bagi guru dan siswa terlebih siswa yang berada di wilayah yang tidak terjaungkau listrik dan jaringan internet; selain itu kondisi ekonomi keluarga juga tambah memperburuk kondisi tersebut; dimana dalam mengakses pembelajaran daring

${ }^{3}$ Penulis lahir di Mebba, Sabu Raijua, 18 Noverber 1990. Penulis merupakan dosen Universitas Nusa Cendana Kupang program studi PGSD, penulis menyelesaikan gelar Sarjana Pendidikan program studi PGSD di Universitas Nusa Cendana (2012), dan menyelesaikan gelar Magister program studi Pendidikan Dasar di Universitas Negeri Malang (2017). 
membutuhkan perangkat elektronik yang tidak semua siswa memiliki perangkat penunjang pembelajaran daring tersebut.

Berbagai upaya yang dilakukan oleh guru khususnya pada wilayah 3T yang memiliki keterbatasan kondisikondisi di atas mulai dari pembelajaran pola shift dimana; pada hari tertentu melaksanakan pembelajaran rolling setiap kelas untuk setiap pertemuan sepuluh orang dengan protokol kesehatan yang ketetat selain itu juga sekolah mengharapkan pembelajaran dengan system jemput tugas yang mana setiap minggu sekolah membuat tugas dan juga bahan pembelajaran yang akan diambil oleh siswa secara bergiliran di sekolah. Kondisi tersebut tentunya membutuhkan strategi yang tepat dalam pelaksanaan, sehingga meskipun dengan keterbatasan-keterbatasan yang ada tidak mengurangi kualitas pembelajaran itu sendiri. Selama masa pandemi, siswa lebih banyak dituntut untuk lebih banyak belajar mandiri yang mana peran aktif dari orang tua dan keluarga menjadi tolak ukur dari keberhasilan siswa.

Zimmerman (Situmorang \& Latifah,2014) mengemukakan Self-Regulated Learning terdiri atas dua dimensi yang diklasifikasikan dalam tiga dimensi yakni kognitif, motivasi, dan metakognitif. Ketiga aspek tersebut memiliki peran dan berhubungan dalam kegiatan belajar. Komponen-komponen tersebut sangat dipengaruhi oleh tingkat kepercayaan seseorang terhadap kemampuannya akan keberhasilan. Seseorang dengan tingkat percaya diri yang tinggi akan lebih mudah dalam menemukan strategi belajar yang tepat dalam belajarnya. Zimmerman (Situmorang \& Latifah,2014) menemukan korelasi antara strategi pengaturan diri dengan prestasi akademik; dimana 
siswa yang memiliki strategi pengaturan diri dalam belajar akan memiliki lebih banyak peluang untuk berhasil dibandingkan dengan anak yang tidak memilikinya.

Strategi Self-Regulated Learning dipandang sesuai dengan kondisi pembelajaran di masa pandemi saat yang memaksa siswa belajar dari rumah. Penerapan strategi SelfRegulated Learning yang dapat dilakukan di rumah dengan bantuan orang tua dan anggota keluarga yakni dengan melakukan pengaturan pada beberapa aspek berikut:

\section{Penetapan Tujuan Belajar}

Seseorang dalam melakukan sebuah aktivitas tentunya memiliki tujuan atas tindakannya tersebut; hal ini juga terjadi pada proses belajar siswa. Melalui penetapan tujuan belajar yang jelas dan terukur maka diharapakan siswa akan memiliki motivasi dalam belajar. Penetapan tujuan belajar bagi siswa sekolah dasar tentunya tidak dapat dilakukan secara mandiri, hal ini tentunya membutuhkan peran serta orang tua dalam membimbing anak dalam mengarahkan dan menemukan tujuan belajarnya. Melalui arahan yang tepat serta bimbingan yang tepat maka akan dapat meningkatkan motivasi belajar anak di rumah.

\section{Pengaturan Waktu Belajar}

Pengaturan waktu belajar merupakan sebuah proses memanajemen waktu yang tepat dalam belajar. Siswa dalam melakukan manajemen waktu belajarnya tentunya membutuhkan bantuan dari orang dewasa yang ada didekatnya. Hal inilah yang membuat peran anggota keluarga khususnya orang tua menjadi factor penentu dalam membatu siswa melakukan manajemen waktu belajarnya. Orang tua dapat melakukan 
manajemen waktu anak dengan mempertimbangkan perkembangan anak; dimana dengan membagi waktu bermain anak dengan waktu belajarnya. Selain itu dengan membangun interaksi yang hangat antar anggota keluarga dapat membatu mewujudkan hal tersebut.

\section{Penataan Lingkungan Belajar}

Belajar merupakan proses yang membutuhkan suasana serta lingkungan yang mendukung dalam melakukan proses tersebut. Melalui penataan lingkungan belajar yang tepat baik lingkungan fisik maupun lingkungan sosial akan menciptakan pengalaman belajar yang nyaman bagi seseorang. Lingkungan belajar memiliki pengaruh terhadap motivasi belajar (Damanik,2019). Melalui motivasi belajar yang tinggi seseorang akan selalu memiliki dorongan dalam belajarnya. Penataan lingkungan belajar dalam kondisi pandemi saat ini tentunya terjadi di rumah, dimana orang tua dapat menata kamar anak atau ruangan yang nyaman bagi anak dalam belajar. Selain itu penataan lingkungan sosial juga perlu diperhatikan melalui pemberian dukungan dari setiap anggota keluarga.

Ketiga aspek di atas, dipandang dapat dilakukan oleh orang tua di rumah dengan harapan dapat membatu siswa dalam meningkatkan kualitas belajarnya di rumah, akan tetapi ketiga strategi di atas dapat tercapai jika ada kepedulian serta kesadaran baik dari orang tua maupun guru terhadap pentingnya pembentukan keterampilan siswa sebagai wujud dalam menciptakan generasi muda yang berkompeten dan mandiri. 


\section{Daftar Pustaka}

Damanik, Bahrudi. 2019. Pengaruh Fasilitas dan Lingkungan Belajar terhadap Motivasi Belajar. Jurnal Publikasi

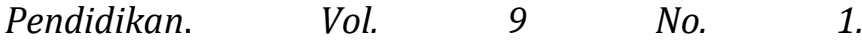
Doi:10.26858/publikan.v9i1.7739

Situmorang,Zelvina., Latifah, Melly. 2014.Pengaruh Dukungan Sosial, Konsep Diri, dan Strategi Pengaturan Diri dalam Belajar terhadap Prestasi Akademik. Jurnal Ilmu Keluarga dan Konsumen. Vol. 7 No. 3. Doi:10.24156/jikk.2014.7.3.154 


\title{
ASESSMENT VIRTUAL PADA PEMBELAJARAN SEKOLAH DASAR DI MASA PANDEMI COVID-19
}

\section{Maria Angelina Fransiska Mbari, S.Pd, M.Pd 4 \\ Universitas Nusa Nipa Indonesia}

\begin{abstract}
"Keberhasilan belajar merupakan tolak ukur kualitas pendidikan yang ada, di masa pandemi covid-19 pendidik dapat melakukan assessment virtual yang bervariatif untuk mengetahui kemampuan perkembangan peserta didik"
\end{abstract}

\begin{abstract}
A ktivitas pendidikan mengalami transformasi yang mendasar karena pandemic covid-19. Begitu juga dengan aktivitas manusia pada bidang yang lain misalnya sosial, ekonomi, agama, kesehatan mengalami perubahan yang cukup fundamental. Pandemi covid 19 telah memperngaruhi semua aspek aktivitas manusia tidak terkecuali dengan dunia pendidikan. Aktivitas pembelajaran di rumah masing-masing menggunakan berbagai televise, zoom, whatsapp dan media-media online lainnya. Aktivitas pembelajaran pada seluruh jenjang pendidikan mulai dari pendidikan dasar, pendidikan menengah, dan pendidikan tinggi terjadi di rumah. Belajar dari Rumah (BDR) adalah
\end{abstract}

${ }^{4}$ Maria Angelina Fransiska Mbari, Lahir di Jopu, Kabupaten Ende, NTT pada tanggal 1 September 1988. Penulis merupakan dosen di Universitas Nusa Nipa Indonesia. Penulis menyelesaikan gelar sarjana Pendidikan Ekonomi di Universitas Nusa Cendana Kupang dan gelar Magister Penelitian dan Evaluasi Pendidikan di Universitas Negeri Jakarta. 
kebijakan pendidikan tentang peralihan pembelajaran tatap muka di satuan pendidikan menjadi pembelajaran di rumah akibat Pandemi COVID-19. Tujuannya, memastikan pemenuhan hak peserta didik untuk mendapatkan layanan pendidikan selama darurat COVID-19, melindungi warga satuan pendidikan dari dampak buruk COVID-19, mencegah penyebaran dan penularan COVID-19 di satuan pendidikan dan memastikan pemenuhan dukungan psikososial bagi pendidik, peserta didik, dan orang tua.

Menurut Mulyasa (2013: 100) "guru harus menyadari bahwa pembelajaran memiliki sifat yang sangat kompleks karena melibatkan aspek pedagogis, psikologis, dan didaktis secara bersamaan. Oleh karena itu, pembelajaran daring bukan sekedar materi yang dipindah melalui media internet, bukan juga sekedar tugas dan soal-soal yang dikirimkan melalui aplikasi sosial media. Pembelajaran daring harus direncanakan, dilaksanakan, serta dievaluasi sama halnya dengan pembelajaran yang terjadi di kelas. Majid (2011:17) " mengatakan bahwa perencanaan dapat diartikan sebagai proses penyusunan materi pelajaran, penggunaan media pengajaran, penggunaan pendekatan dan metode pengajaran, dan penilaian dalam suatu alokasi waktu yang akan dilaksanakan pada masa tertentu untuk mencapai tujuan yang telah ditentukan".

Asessment merupakan bagian terpadu dari proses pembelajaran, memfasilitasi pembelajaran, dan menyediakan informasi yang holistik sebagai umpan balik untuk guru, peserta didik, dan orang tua, agar dapat memandu mereka dalam menentukan strategi pembelajaran selanjutnya.

Asessment dirancang dan dilakukan sesuai dengan fungsi asesment tersebut, dengan keleluasaan untuk 
menentukan teknik dan waktu pelaksanaan asesmen agar efektif mencapai tujuan pembelajaran. Hasil asessment digunakan oleh peserta didik, pendidik, tenaga kependidikan, dan orang tua sebagai bahan refleksi untuk meningkatkan mutu pembelajaran.

Berdasarkan rekomendasi alur pembelajaran di masa kenormalan baru yang di keluarkan oleh Kementrian Pendidikan dan Kebudayaan maka bentuk assessment yang dilakukan adalah assessment diagnosis, assessment formatif reflektif dan assessment sumatif. Asessment Diagnosis: Asessment yang dilakukan sebelum pembelajaran untuk mengetahui kondisi psikososial dan penguasaan pelajaran oleh peserta didik sebagai dasar bagi guru dalam melakukan penyesuaian tujuan, asessment, dan strategi pembelajaran. Asessment diagnosis disarankan dilakukan dalam bentuk sederhana, tidak berisiko dan tidak menentukan nilai akhir peserta didik. Asessment Formatif: Asessment yang dilakukan pada pertengahan pembelajaran untuk mengetahui capaian belajar peserta didik sebagai dasar dalam melakukan penyesuaian dan perbaikan pembelajaran guna memastikan pencapaian tujuan pembelajaran. Asessment formatif disarankan dilakukan dalam bentuk sederhana, tidak berisiko dan tidak menentukan nilai akhir peserta didik. Durasi alur pembelajaran dapat disesuaikan dengan bobot tujuan pembelajaran dengan prinsip semakin pendek durasi akan semakin efektif (kurang lebih 2 minggu) karena guru bisa segera mengetahui apa yang sudah dicapai dan apa yang belum tercapai untuk melakukan perbaikan pembelajaran. Asessment Sumatif: Serangkaian aktivitas yang dilakukan untuk menentukan penguasaan tujuan pembelajaran oleh peserta didik di akhir alur pembelajaran. 
Dalam pembelajaran daring, pemanfaatan sistem pengelola pembelajaran daring atau learning management system (LMS) dapat dioptimalkan untuk proses penilaian. Penilaian ranah kognitif dapat dikembangkan dengan beberapa instrumen berikut:

1. Kuis

Kuis yang dilakukan secara berkesinambungan (setiap akhir minggu) dapat berkontribusi terhadap keberhasilan asesmen sumatif. Asesmen formatif berulang akan membangun motivasi intrinsik dalam diri mahasiswa untuk terlibat lebih dalam terhadap pembelajaran dan melatih penerapan strategi belajar dengan membagi materi menjadi beberapa bagian. Penerapan strategi tersebut dapat meningkatkan retensi pengetahuan jangka panjang dan mendalam.

2. True-false item

True-false item adalah instrumen untuk mengetahui kemampuan kognitif peserta didik. Tes berupa pertanyaan sederhana dan singkat. Persoalan yang peserta didik harus pecahkan adalah kemungkinan jawaban benar (true) atau salah (false).

3. Extended matching item (EMI)

EMI tersusun dari satu tema, pilihan jawaban yang memungkinkan, dasar untuk menghubungkan, dan pertanyaan yang berarah (lead-in) serta suatu skenario. EMI digunakan untuk kemampuan mengingat saja.

4. Multiple choice question (MCQ)

MCQ merupakan metode evaluasi yang paling sering digunakan. MCQ dapat mengevaluasi Bagian pengetahuan secara cepat dan dapat digunakan untuk kelompok mahasiswa yang banyak. 
Proses pembelajaran dalam jaringan (daring) yang diterapkan di Indonesia pada masa pandemi Covid-19, menuntut para pendidik terutama guru untuk menggunakan berbagai model asesmen atau penilaian yang sesuai dan mendukung untuk diterapkan. Karena dalam kondisi yang tidak memungkinkan untuk tatap muka secara langsung kegiatan pembelajaran harus tetap dilakukan meskipun dilakukan di rumah masing-masing atau dimana saja. Adapun Dalam pembelajaran daring, pemanfaatan sistem pengelola pembelajaran daring atau learning management system (LMS) dapat dioptimalkan untuk proses penilaian. berberapa model asesmen yang dapat diterapkan dalam proses pembelajaran pada masa pandemi Covid-19 diantaranya adalah penilaian berbasis daring, penilaian portofolio, dan penilaian karakter. 


\title{
ASESMEN FORMATIF UNTUK MENGETAHUI CAPAIAN BELAJAR MURID
}

\author{
Evy Ramadina, S.Pd.I, M.Pd ${ }^{5}$ \\ UIN Sayyid Ali Rahmatullah Tulungagung
}

"Pemberlakuan pembelajaran daring bukanah alasan seorang pendidik untuk tidak melakukan pemantauan terhadap pencapaian hasil belajar murid. Tantangan inilah

yang seharusnya menjadikan semangat untuk tetap melakukan asesmen formatif"

Pembelajaran jarak jauh sudah berjalan hampir dua tahun. Kerinduan pembelajaran tatap muka dan kekhawatiran akan capaian belajar murid selama pandemi dirasakan oleh berbagai pihak. Namun, kita perlu memberikan kepercayaan pada murid bahwa mereka mampu mengikuti proses pembelajaran meskipun dilaksanakan secara daring. Ruang tatap muka atau tatap maya tentu bukan menjadi persoalan jika guru, orang tua dan lingkungan belajar memahami kebutuhan belajar murid.

Kemampuan belajar murid tidak bisa disamakan dengan banyaknya topik yang harus mereka pelajari selama

5Penulis lahir di Tulungagung, 05 Maret 1993, penulis merupakan Dosen UIN Sayyid Ali Rahmatullah Tulungagung dalam bidang manajemen pendidikan islam, penulis menyelesaikan gelar Sarjana Tadris Matematika di IAIN Tulungagung (2015), sedangkan gelar Magister Pendidikan juga diselesaikan di IAIN Tulungagung Program Manajemen Pendidikan Islam (2017). 
pembelajaran jarak jauh. Banyaknya topik yang diterima oleh murid tidak sebanding dengan kompetensi dari tujuan belajarnya. Kompetensi murid yang sedikit jauh lebih bermakna daripada banyaknya topik yang diberikan. Setiap murid tentunya memiliki capaian belajar yang berbedabeda, sehingga membutuhkan pendekatan yang berbeda pula dalam belajar. Pendidik perlu menyiapkan alat bantu yang dapat memetakan kemampuan belajar murid ini. Alat bantu ini yang nantinya kita sebut dengan asesmen. Asesmen adalah alat bantu bagi pendidik untuk memantau murid selama proses pembelajaran.

\section{Refleksi Pembelajaran di Masa Pandemi}

Pembelajaran yang semula tatap muka dipaksa berubah secara daring atau online. Perubahan ini tentu membutuhkan adaptasi dari semua yang terlibat dalam proses pendidikan. Pembelajaran daring selama masa pandemi Covid-19 ini ada beberapa tantangan yang dihadapi oleh murid, pendidik, orang tua dan pemangku kepentingan.

Adapun tantangan yang dihadapi murid dalam pembelajaran daring seperti quota internet yang tidak mencukupi untuk mendukung pembelajaran synchronous, lokasi rumah yang jaringan internetnya tidak stabil, penugasan yang belum sesuai dengan kebutuhan murid, tantangan belajar yang terlalu mudah, terlalu sulit, dan hanya memindahkan jawaban dari buku teks, serta murid kurang memahami materi yang diberikan karena kurangnya personalisasi pengalaman belajar.

Tantangan yang dihadapi orang tua antara lain ketidaksiapan mendampingi anak belajar dikarenakan tidak memahami materi pembelajaran yang sedang dibahas, tingkat pendidikan orang tua, kondisi orang tua yang 
bekerja sehingga tidak bisa mendampingi anak secara penuh, orang tua tidak memahami proses pembelajaran jarak jauh dan teknis penggunaan teknologi pembelajarannya, tidak mendapatkan umpan balik dari guru untuk perkembangan anaknya selama pembelajaran, serta orang tua belum terlibat dalam kesepakatan pembelajaran jarak jauh.

Sedangkan, tantangan yang dialami pendidik adalah beban administrasi, sarana dan prasarana yang semula tersedia disekolah perlu diadaptasi untuk memanfaatkan konteks lingkungan, pola waktu bekerja tercampur dengan aktivitas pribadi di rumah,

Tantangan tersebut sebagai bentuk refleksi semua pemangku kepentingan untuk mencari cara sehingga dapat terselesaikan demi pembelajaran yang lebih baik. Berikut rekomendasi yang dapat menjadi alternatif pilihan cara untuk menghadapi tantangan pembelajaran jarak jauh selama masa pandemi covid 19.

1. Bagi Sekolah

a. Menggerakan kolaborasi antara guru, murid, dan orang tua

b. Membangun relasi yang positif antara guru, murid, dan orang tua

c. Mengadakan sesi parenting di sekolah terkait pelibatan orang tua dalam satuan pendidikan.

2. Bagi Pendidik

a. Pendidik melakukan observasi terkait profil murid dan orang tua

b. Menyiapkan diferensiasi pembelajaran untuk murid. Penugasan yang menyediakan pilihan cara. Waktu 
pengumpulan yang tidak sama untuk semua murid dengan memperhatikan kondisi orang tua dan profil murid.

c. Melakukan penyesuaian materi ajar dan penugasan

d. Membangun kesepakatan dengan orang tua terkait penugasan murid. Orang tua perlu memahami penugasan anaknya dengan jelas, untuk mendukung pembelajaran anaknya di rumah sehingga bisa membantu murid untuk komitmen dalam proses pembelajaran jarak jauhnya.

e. Memberikan penugasan yang berkaitan dengan konteks di lingkungan sekitar murid. Menghindari tugas yang sekedar memberikan intruksi mengerjakan latihan soal di LKS (Lembar Kerja Siswa)

f. Memberikan umpan balik kepada murid atas proses belajarnya. Umpan balik ini tidak sama dengan reward. Umpan balik ini bisa berupa apresiasi, refleksi, dan mengajak untuk komitmen pada tujuan belajar.

\section{Learning Loss}

Pembelajaran jarak jauh yang berjalan hampir dua tahun ini, memunculkan keresahan apakah murid sudah benar-benar mendapatkan pengalaman belajar, apakah murid sudah belajar sesuai kebutuhannya, dan apakah pembelajaran jarak jauh sudah efektif dalam mengatasi learning loss. Istilah learning loss tidak asing lagi dalam dunia pendidikan. learning loss diartikan sebagai hilangnya kesempatan belajar murid. Terbatasnya pertemuan tatap muka mengakibatkan beberapa murid kesulitan memahami materi sehingga merasa tidak mendapatkan makna belajar. 
Kondisi ini tentu memberikan ancaman dalam dunia pendidikan. langkah langkah strategis perlu diterapkan untuk menghindari terjadinya learning loss. Langkahlangkah strategi itu diantaranya:

1. Lembaga pendidikan menyiapkan media pembelajaran yang sesuai dengan kondisi murid. Salah satu faktor penting pemilihan media pembelajaran adalah ketersediaan jaringan internet dan gawai yang dimiliki murid.

2. Pembelajaran jarak jauh dilakukan dengan sistem pembelajaran campuran. Pembelajaran campuran memadukan antara synchronous dan asynchronous. Pembelajaran synchronous memungkinkan adanya interaksi dan diskusi antara guru dan murid. Sedangkan pembelajaran asynchronous melatih kemandirian belajar murid dengan berkomitmen menyelesaikan pembelajaran tanpa kehadiran guru secara real time.

3. Melakukan asesmen formatif untuk mengetahui sejauh mana pencapaian belajar murid. Perlu ditegaskan bahwa kemampuan dan kompetensi belajar setiap murid itu berbeda-beda, oleh karena itu dibutuhkan asesmen secara berkala untuk memahami sejauh mana capaian belajar muridnya. Dengan melakukan asesmen formatif pendidik bisa mengetahui apakah murid sudah sampai pada tujuan belajar atau apakah dalam proses belajarnya murid membutuhkan pilihan cara mengatasi tantangan belajarnya, Tahap selanjutnya pendidik memetakan pemahaman murid sebagai bekal memasuki topik pembahasan selanjutnya. 


\section{Menyiapkan Asesmen Formatif}

Asesmen formatif adalah proses yang dilakukan pendidik dan murid melihat capaian belajar. Murid mendapatkan umpan balik yang berguna untuk menyesuaikan proses belajar. Tujuan dari asesmen formatif ini melihat sampai mana pemahaman murid, lalu hasil dari asesmen digunakan untuk memetakan pemahaman murid. Asesmen formatif berkaitan erat dengan pemberian umpan balik, berlangsungnya proses pembelajaran, dan memantau sejauh mana pemahaman murid. Maka, murid perlu memahami tujuan pembelajarannya terlebih dahulu sebelum proses belajar dimulai. Sehingga ketika pendidik memberikan umpan balik, murid tersebut juga mengetahui adanya keberhasilan atau kesenjangan yang terjadi antara proses pembelajarannya dan tujuan yang sudah disepakati sebelumnya. Langkah-langkah menyiapkan asesmen formatif:

1. Persiapan

Pada tahap persiapan ini pendidik membuat rencana pelaksanaan asesmen. Rencana ini memuat untuk siapa asesmen ini akan dibuat, kapan pelaksanaan asesmennya, mata pelajaran atau mata kuliah apa yang akan diujikan, dimana tempat pelaksanaannya, bagaimana cara pemberian asesmennya, serta mengidentifikasi apa saja topik prasyaratnya dan topik apa saja yang harus dipelajari pada semester itu.

2. Pelaksanakan

Asesmen formatif bisa dilaksanakan dengan beragam cara. Contohnya pembentukan kelompokkelompok kecil di kelas. Murid diminta untuk berdiskusi dengan temannya tentang topik tertentu, pendidik 
memberikan pertanyaan pemantik diskusi, ketika murid memberikan pendapatnya pendidik bisa mendokumentasikan dengan video, gambar, atau rekaman untuk bisa dilihat kembali nantinya terkait pemahaman muridnya. Contoh strategi yang kedua adalah meminta murid menuliskan pemahamannya terkait topik yang dibahas, murid diperbolehkan menuliskan secara narasi atau bentuk lain. Selain itu pendidik juga bisa memanfaatkan teknologi seperti padlet, flipgrid, atau menggunakan reaction pada aplikasi zoom untuk menanyakan pemahaman murid.

3. Tindak lanjut

Setelah mendapatkan data dari asesmen, hal yang tidak boleh dilupakan adalah pemberian umpan balik. Dari umpan balik ini murid akan memahami sejauh mana pencapaian belajarnya. 


\title{
TRANSFORMASI PENDIDIKAN TINGGI DI ERA MERDEKA BELAJAR KAMPUS MERDEKA
}

\author{
Dr. Hermanu Iriawan, SE., M.Si ${ }^{6}$ \\ Institut IImu Sosial dan Ilmu Pilitik YAPIS Biak
}

"Pendidikan berkualitas adalah syarat mutlak untuk membangun kemajuan bangsa dan Negara. Merdeka belajar kampus merdeka dapat mendorong transformasi pendidikan di Indonesia"

\begin{abstract}
A lvin Toffler (1980) melukiskan milenium ketiga sebagai domain tak dikenal, yang merupakan bentangan masa depan yang tak terpetakan. Perspektif Newtonian mengenai perubahan yang linier dan dapat diramalkan telah usang, digantikan teori kekacauan (chaos theory). Menurut teori ini kehidupan merupakan pertemuan di mana satu peristiwa dapat mengubah peristiwa-peristiwa lain secara tak terduga, bahkan dapat menghancurkan. Perubahan terjadi secara tidak linier, diskontinyu dan tak dapat diramalkan. Kehidupan bukanlah rangkaian peristiwa yang saling terkait dan susul-menyusul.
\end{abstract}

${ }^{6}$ Dr. Hermanu Iriawan, SE., M.Si lahir di Biak 06 Mei 1972. Penulis merupakan dosen PNS di Institut Ilmu Sosial dan Ilmu Politik YAPIS Biak Papua. Penulis menyelesaikan gelar sarjana jurusan Ekonomi Studi Pembangunan di Universitas Cendrawasih Jayapura Papua (1996), menyelesaikan gelar magister jurusan manajemen keunagan di Universitas Hasanuddin Makassar (2010), dan pendidikan Doktoral jurusan Ilmu Administrasi Publik Universitas Hasanuddin Makassar (2020). 
Perubahan itu abadi. Perubahan akan melahirkan peradaban baru dalam tatanan kehidupan di muka bumi dan perubahan lahir dari mimpi, cita-cita, kreativitas, inovasi, kerja nyata, kerja keras, serta kerjasama. Filsuf dan ahli fisika Albert Einstein mengatakan "Ibarat keledai, kebodohan manusia selalu terlihat dalam diri seseorang yang tak mengubah pola hidup, pola pikir, pola sikap, dan pola tindak padahal jelas sudah gagal berkali-kali.

Gejolak perubahan yang berlangsung secara cepat mengakibatkan kesementaraan menjadi sifat hakiki dari kegiatan usaha di masa depan. Dalam bukunya: Kotter (1996) menyebut empat penyebab utama yang memaksa organisasi untuk berubah. Keempat faktor tersebut adalah: perubahan teknologi, integrasi ekonomi internasional, kejenuhan pasar di negara-negara maju serta jatuhnya rezim komunis dan sosialis.

Sejarah mencatat, perubahan senantiasa terjadi melahirkan peradaban baru yang digerakkan oleh ilmu pengetahuan. Revolusi ilmu pengetahuan sejak abad ke-16 yang ditandainya dengan Revolusi Industri 'pertama' atau Revolusi 1.0 pada akhir abad ke-18 di Inggris Raya. Terjadi perubahan proses manufaktur dari tenaga manusia ke mesin.

Ilmu pengetahuan yang berbuah 'teknologi' itu pulalah yang mengantar generasi kita hari ini masuk ke era Revolusi Industri 4.0 yang membawa perubahan besar dalam ekosistem dan tatanan kehidupan masyarakat. Revolusi Industri 4.0 merupakan posisi strategis dunia Pendidikan, terutama perguruan tinggi sebagai pusat riset sekaligus tempat para agen perubahan masa depan bangsa dan negara. 
Dengan konteks inilah, Presiden Jokowi mengambil keputusan 'mengejutkan' menjadikan Nadiem Anwar Makarim toko muda pada kabinet Indonesia Maju sebagai Menteri Pendidikan dan Kebudayaan. Hal ini bernilai sejarah tinggi memilih dan mengangkat 'Menteri Milenial' sebagai konduktor yang memimpin orkestra transformasi negeri ini. Negeri ini harus memiliki loncatan-loncatan perubahan yang signifikan, bertrasformasi agar tidak tersapu badai Revolusi Industri 4.0.

Kemudian penggabungan Kementerian Pendidikan dan Kebudayaan dengan Riset dan Teknologi memberikan pemahaman mengapa Presiden Jokowi kemudian melakukan peleburan. Alasannya riset dan perguruan tinggi adalah 'jalan paling cepat' sekaligus 'paling dekat' dengan dunia nyata yakni dunia kerja yang semakin kompleks dan kompetitif.

Perjalanan panjang sejak tahun 2019 adapun program favorit Menteri Pendidikan, Kebudayaan, Riset dan Teknlogi yang begitu cepat popular dalam dunia Pendidikan yaitu Merdeka Belajar Kampus Merdeka dengan empat kebijakan pokok. Tiga dari empat kebijakan itu menarik untuk dibahas secara mendalam mengenai kesiapan perguruan tinggi swasta dalam menghadapi perubahan tersebut.

Pertama, kebebasan pembukaan studi baru bagi Perguruan Tinggi berakreditasi A dan B agar terbuka peluang bagi lulusan untuk masuk dunia kerja yang nyata dan berkembangan dalam msyarakat. Kedua, Sistem akreditasi perguruan tinggi dalam proses akreditasi bersifat otomatis.bagi perguruan tinggi dan program studi yang layak naik peringkat.

Ketiga, hak kebebasan mahasiswa mengambil prodi lain selama 3 semester di luar program studi. Yang selama 
ini mahasiswa tidak memiliki banyak fleksibilitas untuk mengambil kelas diluar program studi. Dengan arah kebijakan target utama Mas Menteri ingin mengubah kuliah S1 sebagai dunia baru yang berkolaborasi dengan berbagai pihak seperti industri/perusahaan atau organisasi lainnya sehinggah secara bergotong royong mempersiapkan mahasiswa masuk ke dunia nyata dan dunia kerja. Paradigma baru menegaskan Pendidikan tinggi itu tanggungjawab nyata semua pihak.

Adapun manfaat yang dapat diperoleh dalam perubahan kebijakan sebagai penyelenggara Pendidikan Tinggi Swasta, Menciptakan lulusan/mahasiswa bebas belajar menggambil prodi lain dalam kampus atau luar kampus. Jadi mahasiswa tidak lagi terpenjarakan dengan mata kuliah dalam prodi. Tesis dasar Mas Nadim bahwa nyaris tidak ada profesi di dunia zaman ini yang hanya terpaku pada satu disiplin ilmu, yang ada kombinasi/kolaborasi dari beberapa disiplin ilmu.

Dalam tatanan perubahan inisiatif untuk melakukan perubahan dengan berbagai upaya sistematik, Perguruan Tinggi Swasta dituntut untuk melakukan transformasi secara menyeluruh dengan menciptakan ekosistem kampus transformatif berbasis budaya digital. Transformasi menyeluruh meliputi aspek internal kampus diantaranya tata kelola perguruan tinggi, digitalisasi manajemen pelayanan akademik kemahasiswaan, sistem perkuliahan dalam jaringan, sistem evaluasi Pendidikan dan lainnya.

Transformasi Pendidikan di Indonesia sudah saatnya berorientasi pada penciptaan generasi muda yang memiliki karakteristik berikut:

1. Memiliki sifat keyakinan, kemandirian, indivudualisme, dan optimism 
2. Selalu berusaha untuk berprestasi dan memiliki inisiatif

3. Pekerja keras dan memiliki ketekunan

4. Memiliki tingkah laku sebagai pemimpin dan suka terhadap kritik dan saran yang membangun

5. Memiliki perspektif yang berorientasi pada masa depan

Untuk mencetak generasi muda yang berkualifikasi seperti kriteria diatas, maka jalan Merdeka Belajar Kampus Merdeka merupakan jalan menuju kesana. Kuliah di lapangan atau dunia nyata selama 3 semester adalah periode yang cukup memadai bagi mahasiswa untuk mengasah kemampuan berfikir kritis dan kreatif, bersikap adaptif, bekerja keras dan bertanggungjawab.

George dan Jones (2002) menyebutkan sejumlah faktor lingkungan eksternal yang mendorong perubahan, yakni kekuatan kompetisi, kekuatan ekonomi, kekuatan politik, kekuatan globalisasi, kekuatan sosial-demografik, dan kekuatan etikal.

Ada delapan kesalahan yang sering dilakukan yang menyebabkan organisasi mengalami kegagalan dalam melakukan perubahan besar yang diharapkan sebagaimana Kotter (1996):

1. Membiarkan rasa puas diri yang berlebihan. Organisasi membiarkan para karyawan berada dalam zona nyaman terus menerus.

2. Gagal membentuk tim pengarah perubahan yang kuat. Perubahan didelegasikan terlalu jauh.

3. Menganggap remeh kekuatan suatu visi. Organisasi tidak percaya kekuatan suatu visi, sehingga tidak 
cukup meluangkan waktu untuk membuat visi yang jelas. Visi hanya dianggap sekedar suatu pernyataan. Sekedar formalitas.

4. Visi tidak dikomunikasikan dengan baik.

5. Membiarkan rintangan yang menghadang pencapaian visi. Struktur organisasi, uraian jabatan, sistem penilaian prestasi serta mekanisme kenaikan gaji/bonus seringkali menjadi habitat yang buruk untuk hidupnya visi baru.

6. Gagal mendapatkan kemenangan jangka pendek. Perubahan mendasar memerlukan waktu panjang. Dalam menjalaninya perlu dibuat sasaran-sasaran antara yang memungkinkan para personil merasa mencapai suatu keberhasilan dan berhak merayakannya sebagai kemenangan. Tanpa kemenangan jangka pendek, para karyawan akan frustasi dan gagal mencapai perubahan besar.

7. Terlalu cepat menyatakan kemenangan akhir. Suatu perubahan yang telah dicapai umumnya masih labil. Mudah sekali untuk kembali ke keadaan semula. Jika kemenangan akhir dinyatakan terlalu dini dan hasil perubahan tidak dijaga dengan baik, kembalinya perubahan yang telah terjadi ke kondisi semula sangat mungkin terjadi.

8. Gagal membakukan perubahan ke dalam budaya perusahaan. Budaya perusahaan diyakini sebagai kumpulan perilaku-perilaku yang ditunjukkan oleh para karyawan dalam kegiatan sehari-hari. Jika perubahan tidak dapat diabadikan ke dalam perilaku karyawan dalam kegiatan sehari-hari, maka 
lambat laun perubahan yang telah dicapai akan memudar.

\section{Daftar Pustaka}

George, Jenifer M., and Jones Gareth R., 2002, Organizational Behavior, 3rd edition, Prentice Hall International Incorporation, New Jersey.

Kotter, John, P., dan Heskett, James, L., 2008. Corporate Culture and Performance. Kindle Edition. , 1992, Corporate Culture and Performance, The Free Press, New York.

Kotter, J..P., 1996, Leading Change, Boston, MA, Havard Business Schooll Press.

Toffler, Alvin, 1980. The Third Wave, Bantam Books.

Albert Einstein, 2000, Freeman (Pengantar), Alice Calaprice

(Editor), The Expanded Quotable Einstein, edisi 2, Princeton University Press.

Peraturan Perundang-undangan:

Permendikbud Nomor 3 Tahun 2020 tentang Standar Nasional Pendidikan Tinggi

Permendikbud Nomor 5 Tahun 2020 Tentang Akreditasi Program Studi dan Perguruan Tinggi

Permendikbud Nomor 7 tentang Pendirian, Perubahan, Pembubaran Perguruan Tinggi Negeri dan Pendirian, Perubahan, dan Pencabutan Izin Perguruan Tinggi Swasta. 


\title{
COVID 19 DAN DISRUPSI PENDIDIKAN
}

\author{
Dr. Wara Sabon Dominikus, M.Sc ${ }^{7}$ \\ Universitas Nusa Cendana
}

"Apa korelasi covid 19 dengan disrupsi pendidikan? Tentunya perubahan besar-besaran yang terjadi ini disebabkan oleh adanya inovasi mengubah sistem pendidikan yang lebih baru karena upaya adaptasi dengan suatu keadaan"

\section{Covid 19 dan Dampaknya}

$\mathrm{V}$ irus Corona yang lebih dikenal dengan Covid 19 sedang memporak porandakan berbagai segi kehidupan manusia juga kehidupan berbangsa dan bernegara. Vaksin sudah ditemukan dan akan terus dikembangkan. Obatnya pun masih terus dalam proses penemuan walaupun telah muncul berbagai klaim dari para ilmuwan dari berbagai Negara akan penemuan obat untuk virus Corona ini. Merebaknya virus corona di berbagai Negara membuat kelabakan berbagai pihak baik para medis, pemerintah, maupun masyarakat bahkan telah merengut banyak korban jiwa.

Banyak masyarakat yang harus kehilangan pekerjaan yang pada akhirnya turut memengaruhi aspek kehidupan lainnya. Pemutusan Hubungan Kerja (PHK) semakin meningkat dari waktu ke waktu. Daya beli masyarakat menurun, pasar sepi, dagangan tidak laku. Kemampuan

${ }^{7}$ Penulis adalah dosen Pendidikan Matematika di Universitas Nusa 
membiayai pendidikan tentu bermasalah juga. Moda transportasi pada sepi penumpang. Sebaliknya meningkatnya layanan paket pesanan makanan dan kebutuhan lainnya melalui GoJek. Pandemi Covid 19 telah menjadi masalah global dan membuat perubahan hidup yang tidak terbayangkan sebelumnya. Pandemi Covid 19 telah memutarbalikkan berbagai fakta kehidupan. Slogan bersatu kita teguh bercerai kita runtuh sepertinya tidak cocok lagi di masa pandemic covid 19 ini. Bersatu secara fisik (berkumpul bersama) dalam kerumunan tidak diperbolehkan karena berpotensi terjadinya penularan virus corona. Dengan berdiam di rumah masing-masing akan memutus mata rantai penyebaran covid 19. Mudik lebaran yang sudah menjadi budaya untuk moment berkumpulnya keluarga pun dilarang pemerintah demi keselamatan keluarga. Tidak mudik sangat membantu untuk memperkecil jumlah orang yang dapat menjadi pembawa covid 19 bagi orang lain atau daerah lain.

Di sisi lain covid 19 telah membangkitkan kembali kemanusiaan warga masyarakat. Semangat solidaritas masyarakat pun bermunculan dan dilakukan seperti yang dipublikasikan di media massa. . Penggalangan dana solidaritas covid 19 dilakukan oleh berbagai kalangan masyarakat baik secara lembaga maupun perorangan. Ada Bantuan paket-paket sembako, masker, Alat Pelindung Diri (APD) yang diserahkan ke masyarakat yang terdampak oleh covid 19. Spontanitas masyarakat untuk membangun posko-posko Covid 19 di tiap desa dan lingkungan RT dan RW. Empati kepada para tenaga medis diekspresikan dalam berbagai bentuk, ada lagu, ada puisi, ada slogan, ada bantuan material dan sentuhan psikologis yang menguatkan dan meneguhkan para tenaga medis. Kondisi ini 
menggambarkan bahwa covid 19 telah mendisrupsi kehidupan dan berdampak positif dan negatif sekaligus.

\section{Aneka Disrupsi}

Disrupsi sudah terjadi sejak ditemukan Teori Disrupsi oleh Christensen pada tahun 1980. Baginya disrupsi merupakan sebuah inovasi. Inovasi yang akan menggantikan seluruh system dan cara lama dengan system dan cara-cara baru. Disruption menggantikan teknologi lama yang serba fisik dengan teknologi digital yang menghasilkan sesuatu yang benar-benar baru dan lebih efisien, dan juga lebih bermanfaat (Kasali, 2017). Sejak 1980 telah terjadi kurang lebih 20 episode kejutan (disrupsi) yang disebabkan oleh Teknologi (khususnya IT), Teori manajemen (metode baru pengelolaan SDM, kepemimpinan, produksi dan bisnis), Peristiwa ekonomi ( peran negara, Bank sentral), Daya saing global, dan geopolitik (ketegangan antar wilayah). Bagi siapa saja yang tidak mampu beradaptasi dengan perubahan yang terjadi akan semakin cepat tergusur dan membuat usaha atau layanan mati. Chistensen (dalam Kasali, 2017) menegasakan bahwa disrupsi menggantikan pasar lama, industry, dan teknologi, dan menghasilkan suatu kebaruan yang lebih efisien dan menyeluruh. Disrupsi juga bersifat destruktif dan kreatif. Disrupsi juga sebuah inovasi yang akan menggantikan seluruh system lama dengan cara -cara baru.

Beberapa contoh berikut kiranya memberikan gambaran tentang disrupsi kehidupan manusia dewasa ini. ALibaba.com, e-commerce asal China, telah mendisrupsi dunia dengan mempermudah pencarian dan transaksi dari pemasok-pemasok dari berbagai Negara Asia dan China, yang membuat importer Amerika senang karena mudah dan relatif murah serta accessible. Bukalapak, model bisnis 
yang mempertemukan para pelaku UMKM Indonesia yang kesulitan memasarkan produknya dengan para konsumen yang mencari barang-barang murah. Model bisnis baru ini tak terlihat dan tidak disadari oleh para pelaku bisnis lama (incumbent).. GoJek mampu melayani berbagai kebutuhan calon penumpang. Pengemudi datang dari berbagai wilayah dan memiliki ratusan ribu armada. Saat ini GoJek juga melayani pesanan makanan, jasa pembersih rumah, jasa pijat, dll (Kasali, 2019). GoJek dengan mottonya: An Ojek for Every Need, telah mendisrupsi pangkalan dan jasa ojek konvensional. Dengan teknologi atau applikasinya GoJek telah mereduksi jumlah pangkalan ojek yang kita jumpai di tikungan-tikungan jalan atau persimpangan jalan masuk ke perkampungan. Perkembangan teknologi yang sangat pesat berkontribusi besar pada berbagai perubahan di berbagai bidang yang sudah tentu berdampak positif tapi juga berdampak negatif. Di satu sisi membuka lapangan kerja baru tapi di lain sisi membuat kehilangan pekerjaan demi alasan efisiensi.

\section{Disrupsi Pendidikan}

Dunia pendidikan pun telah terdisrupsi dari waktu ke waktu. Inovasi pembelajaran, model pembelajaran dan teori belajar pun telah dikembangkan dan dihasilkan. Pembelajaran yang berpusat pada guru (Teacher center learning) diganti dengan pembelajaran yang berpusat pada siswa (student center learning). Guru tidak lagi menjadi satu-satunya sumber belajar yang dari padanya para peserta didik memperoleh pengetahuan baru. Siswa lebih kreatif dalam proses belajar membentuk dan menemukan pengetahuan baru paling tidak menemukan kembali apa yang telah ditemukan sebelumnya (reinvention). 
Pembelajaran daring atau pembelajaran online telah lama diperkenalkan namun belum banyak dimanfaatkan dalam dunia pendidikan karena berbagai alasan. Rusman mengemukakan bahwa paling tidak ada tiga alasan mengapa pembelajaran tatap muka masih dibutuhkan dalam kegiatan pembelajaran (Rusman, 2012) antara lain: pertama, diperlukan tatap muka untuk menjelaskan maskud dan mekanisme belajar yang akan dilewati bersama secara langsung dengan siswa. Kedua, perlunya memahamkan siswa dan memberikan pengalaman belajar melalui kerja kelompok dan kolaboratif pada siswa. Ketiga, perlunya melatih siswa untuk memanfaatkan computer dan sarana IT lainnya sebagai media komunikasi berbasis web.

Pembelajaran online atau elearning yang selama ini diabaikan oleh para pendidik, kini dipaksa untuk digunakan karena tidak ada pilihan lain yang lebih efektif demi mendukung membantu memutus mata rantai penyebaran virus corona. Ada dampak positif covid 19 bagi para pendidik untuk mendisrupsi diri dalam meningkatkan pemahaman dan kemampuan serta keterampilan menggunakan elearning. Para pendidik dipaksa untuk memaksa dirinya masuk terlibat langsung dalam dunia pembelajaran online.

Disrupsi dalam dunia pendidikan menuntut guru, siswa, dan orangtua serta pemangku kepentingan pendidikan untuk turut mendisrupsi diri. Butuh mental untuk mau berubah. Butuh niat untuk berubah untuk menjawabi perubahan yang terjadi dalam dunia pendidikan. Ada 3 kelompok orang dalam menyikapi perubahan atau disrupsi pendidikan. Pertama, kelompok yang tidak mau berubah. Kelompok ini sudah nyaman dengan apa yang sudah dimilikinya selama ini. Tidak mau berpindah ke 
pembelajaran online dengan berbagai alasan seperti ketiadaan pulsa data dan jaringan internet, tidak ada smartphone dan penolakan lainnya. Kedua, kelompok yang ikut mau berubah. Tapi ketika menemui hambatan mereka akan menanggapinya dengan cara seperti saya sudah berusaha tetapi jaringan tidak bisa, hasilnya tidak baik, buang-buang waktu saja. Mereka sudah bisa mengatasi hambatan mental pada awalnya tetapi ketika menghadapi hambatan fisik mereka tidak sanggup. Ketiga, kelompok yang sadar akan pentingnya berubah. Merek siap dan mampu mengatasi hambatan mental dan mau berubah demi kemajuan. Ketika menemuai hambatan fisik mereka siap berlatih secara konsisten dan disiplin sehingga lambat laun apa yang dirasa sulit jadi mudah, dulunya bimbang jadi yakin. Akhirnya akan menyukai dan menggunakan pembelajaran online seterusnya. Bagi mereka badai covid 19 berlalu, pembelajaran online pilihannya.

Disrupsi dalam dunia pendidikan, terutama di era pandemic covid 19, menjadi daya dorong bahkan daya paksa untuk memasuki budaya digital. Digitalisasi pendidikan secara khusus digitalisasi pembelajaran berkembang pesat seiring perkembangan teknologi. Patut diingat bahwa budaya digital akan melahirkan banyak kontradiksi yang menegangkan, penuh ketidak pastian bahkan rentan konflik baik pada level makro maupun pada level mikro (Sugiharto, 2019). Beberapa kontradiksi diantaranya: pertama, Integratif sekaligus fragmentatif. Teknologi digital seolah mengoneksikan manusia sejagat raya. Namun isi komunikasi yang berhamburan tanpa kendali berpotensi memecah-belah dan timbul polarisasi dalam masyarakat. Kedua, Kaya informasi tapi melahirkan kedangkalan berpikir. Informasi datang dan pergi begitu 
cepat dari segala arah. Kaya pengetahuan dan luas wawasan, terbuka bagi siapapun yang mencarinya, terbuka untuk diakses oleh siapa pun dan dari manapun serta kapanpun. Namun kenyataan pola piker dan pola hubungan cenderung reaktif, emosional, dangkal, dan tidak reflektif. Ketiga, Melimpahnya kreativitas tapi kehilangan arah. Kreativitas terbuka luas dan melahirkan banyak hal baru tapi sekaligus menimbulkan banyak disrupsi yang tak terkendali. Akibatnya, prioritas nilai terus-menerus berubah, yang sesungguhnya berharga dalam hidup menjadi semakin kabur.

\section{Daftar Pusataka}

Cahyadi, H. 2017. Paideia: Mendidik Negarawan Menurut Platon, Yogyakarta: PT. Kanisius

Kasali, R. 2017. Disruption, Jakarta: PT. Gramedia Pustaka Utama

Kasali, R. 2019. \#MO, Sebuah Dunia Baru Yang Membuat Banyak Orang Gagal Paham, Jakarta: Mizan

Rusman. 2013. Model-Model Pembelajaran:Mengembangkan Profesionalisme Guru, Jakarta: PT Raja Grafindo Persada

Sugiharto, B. 2019. Kebudayaan dan Kondisi Post-Tradisi, Yogyakarta: PT Kanisius 


\title{
PRESTASI SISWA MAN 1 GROBOGAN \\ DI MASA PANDEMI
}

\author{
Yus Marlena, S.Pd 8 \\ Madrasah Aliyah Negeri 1 Grobogan
}

"Pandemi covid-19 bukan ajang untuk melemahkan akademi melainkan semangat untuk meraih prestasi"

emenjak Virus Covid 19 merebak diseluruh dunia, semua
Negara di dunia menerapkan lockdown dalam rangka memutus rantai penyebaran Virus Covid 19 tak terkecuali dengan Indonesia. Korban Virus 19 telah merenggut ribuan jiwa, Indonesia termasuk Negara yang tertinggi tingkat penularan virus Covid 19 dengan tingkat kematian yang tinggi. Di kutip dari kompasiana beyond blogging bahwasannya hingga tanggal 3 Juli 2021, total pasien Covid19 berjumlah kurang lebih 2,26 juta jiwa, dinyatakan sembuh berjumlah kurang lebih 1,92 juta jiwa dan jumlah yang meninggal adalah lebih dari 60.000 jiwa. Akibat meledaknya jumlah pasien Covid tersebut, maka pemerintah mengambil langkah untuk memberlakukan PPKM darurat yang dilaksanakan dari tanggal 3 Juli sampai dengan tanggal 20 Juli 2021 dan masih diperpanjang terus hingga kini. Dampak dari adanya PPKM yang ditetapkan oleh pemerintah mengharuskan semua pelajar dari jenjang TK, SD, SLTP, SLTA maupun Mahasiswa semua harus belajar

8Penulis lahir di Pati, 2 Juli 1974, penulis merupakan guru di MAN 1 Grobogan. Penulis menyelesaikan gelar sarjana di UNNES (1998). 
secara daring dari rumah, sehingga semua aktivitas pembelajaran yang semula dapat dilakukan dengan tatap muka menjadi terhenti karena harus digantikan secara daring, peserta didik yang semula dapat berdiskusi dengan sesama teman, bertukar fikiran, melakukan aktivitas penyaluran bakat dan minat melalui kegiatan ekstra kurikuler secara langsung, baik dalam ekstra kepramukaan, baris berbaris, karya ilmiah remaja, PMR, dan lain sebagainya, kini hanya dapat dilakukan secara daring.

Siswa MAN 1 Grobogan sebagai salah satu peserta didik di satuan pendidikan setara SMA yang juga terkena dampak PPKM, harus mengikuti program pembelajaran daring yang sebagaimana telah digulirkan oleh menteri pendidikan, meskipun demikian, tidak menyurutkan semangat berprestasi para siswa, sehingga hampir dua tahun dua tahun terhitung sejak maret 2019 hingga kini siswa MAN 1 Grobogan terus mengukir prestasi baik prestasi akademik maupun prestasi non akademik, baik di tingkat kabupaten, propinsi, maupun tingkat nasional bahkan tingkat ASIA di bawah kepemimpinan Bapak Drs.H.Suprapto,M.Pd., siswa siswi MAN 1 Grobogan berani bersaing dengan para siswa yang lain dari berbagai penjuru daerah maupun Negara Asia. Adapun prestasi yang berahasil di siswa MAN 1 grobogan selama pandemic diantaranya:

Perolehan Juara Lomba Oleh Siswa Man 1 Grobogan

Tahun Pelajaran 2019/2020-2020/2021 Di Masa Pandemi

\begin{tabular}{|l|l|l|l|l|l|l|c|}
\hline $\begin{array}{c}\text { N } \\
\mathbf{0}\end{array}$ & NAMA & $\begin{array}{c}\text { KEL } \\
\text { AS }\end{array}$ & $\begin{array}{c}\text { JUAR } \\
\text { A }\end{array}$ & KEGIATAN & $\begin{array}{c}\text { PANITI } \\
\text { A }\end{array}$ & LEVEL & $\begin{array}{c}\text { Wak } \\
\text { tu }\end{array}$ \\
\hline 1 & Tim & & Juara & LCTP & Logara & Prop & 11,1 \\
& Pramuka & & 3 & & $\begin{array}{l}\text { wa Uin } \\
\text { Walisin } \\
\text { go }\end{array}$ & & 2 Juli \\
& & & & & & & \\
& & & & & & & \\
& & & & & & & \\
\hline
\end{tabular}




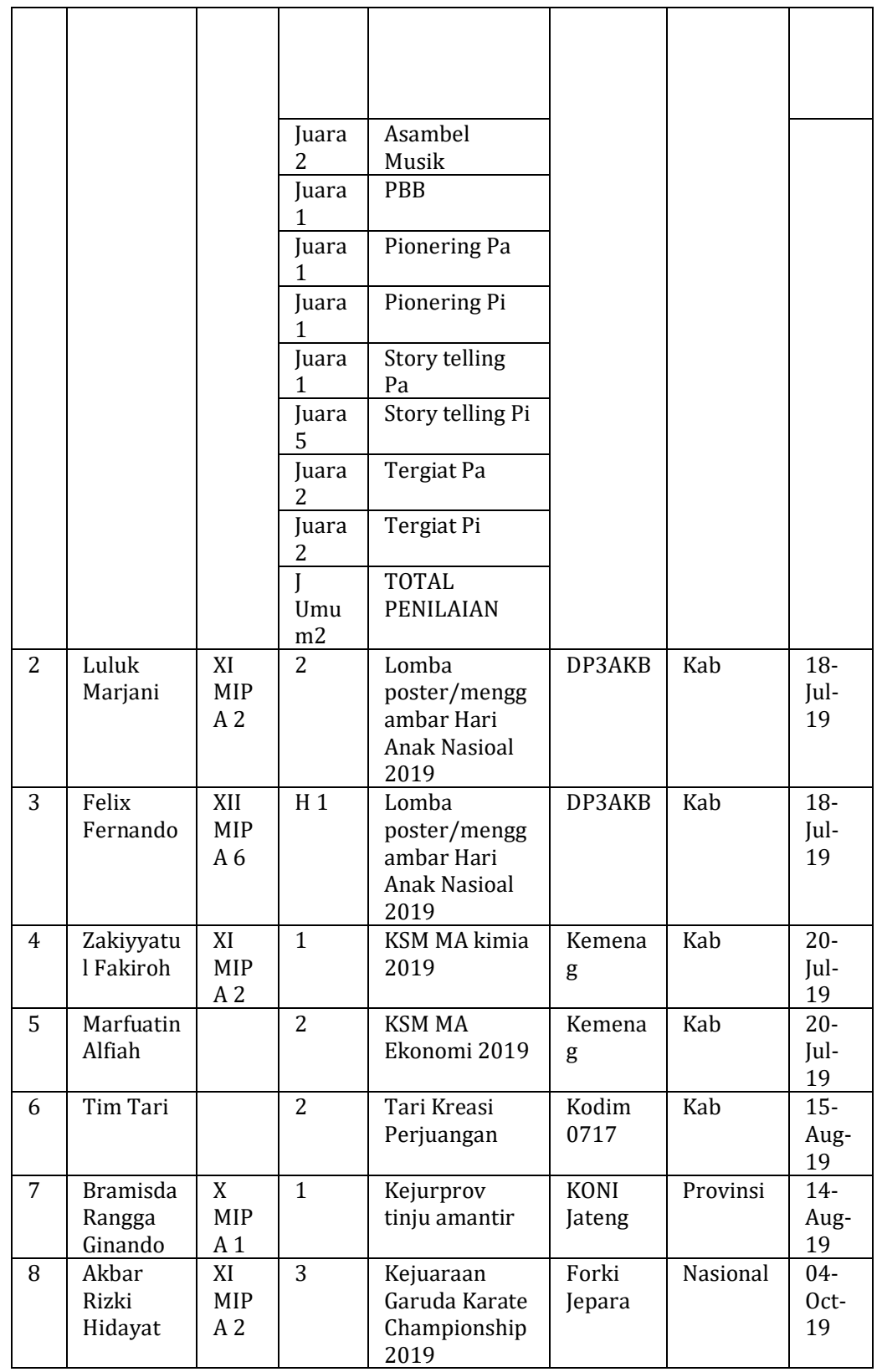




\begin{tabular}{|c|c|c|c|c|c|c|c|}
\hline 9 & $\begin{array}{l}\text { Haris } \\
\text { Rizki } \\
\text { Erlangga } \\
\end{array}$ & $\begin{array}{l}\text { XI } \\
\text { MIP } \\
\text { A } 2 \\
\end{array}$ & 1 & Pencak Silat & $\begin{array}{l}\text { IPSI } \\
\text { Semara } \\
\text { ng }\end{array}$ & Jateng & $\begin{array}{l}13- \\
\text { Oct- } \\
19\end{array}$ \\
\hline $\begin{array}{l}1 \\
0\end{array}$ & $\begin{array}{l}\text { Pramuka } \\
\mathrm{Pi}\end{array}$ & & 1 & Vlog PW & $\begin{array}{l}\text { Kwarca } \\
\text { b }\end{array}$ & Kab & $\begin{array}{l}20- \\
\text { Oct- } \\
19\end{array}$ \\
\hline $\begin{array}{l}1 \\
1\end{array}$ & $\begin{array}{l}\text { Pramuka } \\
\text { PA }\end{array}$ & & 1 & LCTP Pramuka & Kwaran & Kec & $\begin{array}{l}21- \\
\text { Oct- } \\
19 \\
\end{array}$ \\
\hline $\begin{array}{l}1 \\
2\end{array}$ & $\begin{array}{l}\text { Pramuka } \\
\text { pi }\end{array}$ & & 2 & LCTP Pramuka & Kwaran & $\mathrm{Kec}$ & $\begin{array}{l}21- \\
\text { Oct- } \\
19 \\
\end{array}$ \\
\hline \multirow[t]{3}{*}{$\begin{array}{l}1 \\
3\end{array}$} & \multirow[t]{3}{*}{ Kopbara } & & $\begin{array}{l}\text { Hrp } \\
\text { Ut } 3\end{array}$ & $\begin{array}{l}\text { Katagori } \\
\text { SMA/SMK/SM } \\
\text { A }\end{array}$ & SMA N 6 & Jateng & $\begin{array}{l}20- \\
\text { Oct- } \\
19\end{array}$ \\
\hline & & & 3 & $\begin{array}{l}\text { Variasi } \\
\text { formasi BB }\end{array}$ & SMA N 6 & Jateng & $\begin{array}{l}20- \\
\text { Oct- } \\
19\end{array}$ \\
\hline & & & 1 & $\begin{array}{l}\text { Kategori } \\
\text { SMA/MA }\end{array}$ & SMA N 6 & Jateng & $\begin{array}{l}20- \\
\text { Oct- } \\
19 \\
\end{array}$ \\
\hline \multirow[t]{4}{*}{$\begin{array}{l}1 \\
4\end{array}$} & $\begin{array}{l}\text { Pramuka } \\
\mathrm{Pa}\end{array}$ & & 1 & LCTP Pramuka & $\begin{array}{l}\text { Kwarca } \\
\text { b }\end{array}$ & Kab & $\begin{array}{l}27- \\
\text { Oct- } \\
19\end{array}$ \\
\hline & $\begin{array}{l}\text { Febriyan } \\
\text { Wahyu } \\
\text { Putra } \\
\text { Ananda }\end{array}$ & $\begin{array}{l}\text { XI } \\
\text { MIP } \\
\text { A } 2\end{array}$ & & & & & \\
\hline & $\begin{array}{l}\text { Muhamm } \\
\text { ad } \\
\text { Setyawan }\end{array}$ & $\begin{array}{l}\mathrm{Xi} \\
\mathrm{MPA} \\
6 \\
\end{array}$ & & & & & \\
\hline & $\begin{array}{l}\text { Ahmas } \\
\text { Makruf }\end{array}$ & $\begin{array}{l}\text { XII } \\
\text { MIP } \\
\text { A 2 } \\
\end{array}$ & & & & & \\
\hline \multirow[t]{4}{*}{$\begin{array}{l}1 \\
5\end{array}$} & $\begin{array}{l}\text { Tria } \\
\text { Mir'atul } \\
\text { Mukarom } \\
\text { ah } \\
\end{array}$ & & 3 & $\begin{array}{l}\text { Lomba Cipta } \\
\text { inovasi TTG }\end{array}$ & $\begin{array}{l}\text { Disperm } \\
\text { as }\end{array}$ & $\mathrm{Kab}$ & $\begin{array}{l}30- \\
\text { Oct- } \\
19\end{array}$ \\
\hline & $\begin{array}{l}\text { Aliya } \\
\text { Mufida } \\
\text { Isnaini } \\
\end{array}$ & & & $\begin{array}{l}\text { alat pengupas } \\
\text { kuwaci }\end{array}$ & & & \\
\hline & $\begin{array}{l}\text { Diyas } \\
\text { Rizki } \\
\text { Dewansh } \\
\text { ah } \\
\end{array}$ & & & & & & \\
\hline & $\begin{array}{l}\text { Aqila } \\
\text { Maiquina }\end{array}$ & & & & & & \\
\hline $\begin{array}{l}1 \\
6\end{array}$ & $\begin{array}{l}\text { Wulan } \\
\text { Pebianti }\end{array}$ & & Hrp 3 & $\begin{array}{l}\text { Lomba Cipta } \\
\text { onovasi TTG }\end{array}$ & $\begin{array}{l}\text { Disperm } \\
\text { as }\end{array}$ & Kab & $\begin{array}{l}30- \\
\text { Oct- } \\
19 \\
\end{array}$ \\
\hline
\end{tabular}




\begin{tabular}{|c|c|c|c|c|c|c|c|}
\hline & $\begin{array}{l}\text { Vinorika } \\
\text { Bunga W }\end{array}$ & & & $\begin{array}{l}\text { alat pembersih } \\
\text { air }\end{array}$ & & & \\
\hline & $\begin{array}{l}\text { Alif Nurul } \\
\text { Musthofa }\end{array}$ & & & & & & \\
\hline $\begin{array}{l}1 \\
7\end{array}$ & $\begin{array}{l}\text { Nur } \\
\text { Sofiandi }\end{array}$ & $\begin{array}{l}\text { X } \\
\text { MIP } \\
\text { A } 5\end{array}$ & 3 & $\begin{array}{l}\text { Taekwondo } \\
\text { UNS }\end{array}$ & $\begin{array}{l}\text { UKM } \\
\text { Taekwo } \\
\text { ndo } \\
\text { UNS }\end{array}$ & Prov & $\begin{array}{l}02- \\
\text { Nov- } \\
19\end{array}$ \\
\hline $\begin{array}{l}1 \\
8\end{array}$ & $\begin{array}{l}\text { Rizki } \\
\text { Hermawa } \\
\mathrm{n}\end{array}$ & $\begin{array}{l}\text { XI } \\
\text { MIP } \\
\text { A } 1 \\
\end{array}$ & 1 & TIMO & TIMO & Nasional & $\begin{array}{l}05- \\
\text { Oct- } \\
19 \\
\end{array}$ \\
\hline $\begin{array}{l}1 \\
9\end{array}$ & $\begin{array}{l}\text { Pusparan } \\
\text { i Putri } \\
\text { Kinasih } \\
\end{array}$ & $\begin{array}{l}\text { XI } \\
\text { MIP } \\
\text { A } 2 \\
\end{array}$ & 1 & TIMO & TIMO & Nasional & $\begin{array}{l}05- \\
\text { Oct- } \\
19 \\
\end{array}$ \\
\hline $\begin{array}{l}2 \\
0\end{array}$ & $\begin{array}{l}\text { Umi } \\
\text { Windasar } \\
\mathrm{i}\end{array}$ & $\begin{array}{l}\text { XI } \\
\text { MIP } \\
\text { A } 2 \\
\end{array}$ & 2 & TIMO & TIMO & Nasional & $\begin{array}{l}05- \\
\text { Oct- } \\
19 \\
\end{array}$ \\
\hline $\begin{array}{l}2 \\
1\end{array}$ & $\begin{array}{l}\text { Widya Tri } \\
\text { Susanti }\end{array}$ & $\begin{array}{l}\text { XI } \\
\text { MIP } \\
\text { A } 2 \\
\end{array}$ & 2 & TIMO & TIMO & Nasional & $\begin{array}{l}05- \\
\text { Oct- } \\
19\end{array}$ \\
\hline $\begin{array}{l}2 \\
2\end{array}$ & $\begin{array}{l}\text { Fedhila } \\
\text { Fieldhath } \\
\text { ama }\end{array}$ & $\begin{array}{l}\text { X } \\
\text { MIP } \\
\text { A } 2 \\
\end{array}$ & 2 & TIMO & TIMO & Nasional & $\begin{array}{l}05- \\
\text { Oct- } \\
19 \\
\end{array}$ \\
\hline $\begin{array}{l}2 \\
3\end{array}$ & $\begin{array}{l}\text { Anjani } \\
\text { Pramesti }\end{array}$ & $\begin{array}{l}\text { X } \\
\text { MIP } \\
\text { A } 6 \\
\end{array}$ & 3 & TIMO & TIMO & Nasional & $\begin{array}{l}05- \\
\text { Oct- } \\
19 \\
\end{array}$ \\
\hline $\begin{array}{l}2 \\
4\end{array}$ & $\begin{array}{l}\text { Feby } \\
\text { Nurmalia } \\
\text { Hidayat }\end{array}$ & $\begin{array}{l}\text { XI } \\
\text { MIP } \\
\text { A 1 } \\
\end{array}$ & 1 & $\begin{array}{l}\text { Taekwondo } \\
\text { Koni Kudus } 2 \\
\text { kelas U52 Pi }\end{array}$ & $\begin{array}{l}\text { Koni } \\
\text { Kudus }\end{array}$ & $\begin{array}{l}\text { Kareside } \\
\text { nan }\end{array}$ & $\begin{array}{l}10- \\
\text { Nov- } \\
19 \\
\end{array}$ \\
\hline $\begin{array}{l}2 \\
5\end{array}$ & $\begin{array}{l}\text { Aura } \\
\text { Veranisya } \\
\text { h Sudarto } \\
\end{array}$ & $\begin{array}{l}\text { XI } \\
\text { MIP } \\
\text { A } 1 \\
\end{array}$ & 2 & $\begin{array}{l}\text { Taekwondo } \\
\text { Koni Kudus } 2 \\
\text { kelas U46 Pi }\end{array}$ & $\begin{array}{l}\text { Koni } \\
\text { Kudus }\end{array}$ & $\begin{array}{l}\text { Kareside } \\
\text { nan }\end{array}$ & $\begin{array}{l}10- \\
\text { Nov- } \\
19 \\
\end{array}$ \\
\hline $\begin{array}{l}2 \\
6\end{array}$ & $\begin{array}{l}\text { Maulida } \\
\text { Kholifatu } \\
\text { s } \\
\text { Zuhriyah }\end{array}$ & $\begin{array}{l}\text { XI } \\
\text { MIP } \\
\text { A } 1\end{array}$ & 2 & $\begin{array}{l}\text { Taekwondo } \\
\text { Koni Kudus } 2 \\
\text { kelas U49 Pi }\end{array}$ & $\begin{array}{l}\text { Koni } \\
\text { Kudus }\end{array}$ & $\begin{array}{l}\text { Kareside } \\
\text { nan }\end{array}$ & $\begin{array}{l}10- \\
\text { Nov- } \\
19\end{array}$ \\
\hline $\begin{array}{l}2 \\
7\end{array}$ & $\begin{array}{l}\text { Pramuka } \\
\mathrm{Pa}\end{array}$ & & 2 & LCTP Pramuka & Binwil & $\begin{array}{l}\text { Kareside } \\
\text { nan }\end{array}$ & $\begin{array}{l}17- \\
\text { Nov- } \\
19 \\
\end{array}$ \\
\hline $\begin{array}{l}2 \\
8\end{array}$ & $\begin{array}{l}\text { Upik } \\
\text { Catur } \\
\text { Hidayat } \\
\end{array}$ & $\begin{array}{l}\text { XI } \\
\text { MIP } \\
\text { A } 1 \\
\end{array}$ & 1 & $\begin{array}{l}\text { Kejurkab } \\
\text { Tenis Meja }\end{array}$ & $\begin{array}{l}\text { PTSMSI } \\
\text { Cabang } \\
\text { Grob }\end{array}$ & Kab & $\begin{array}{l}07- \\
\text { Dec- } \\
19 \\
\end{array}$ \\
\hline $\begin{array}{l}2 \\
9\end{array}$ & $\begin{array}{l}\text { Nurul } \\
\text { Hidayat }\end{array}$ & $\begin{array}{l}\text { XII } \\
\text { IPS } 2\end{array}$ & 1 & $\begin{array}{l}\text { Kejurkab } \\
\text { Tenis Meja }\end{array}$ & $\begin{array}{l}\text { PTSMSI } \\
\text { Cabang } \\
\text { Grob }\end{array}$ & Kab & $\begin{array}{l}07- \\
\text { Dec- } \\
19\end{array}$ \\
\hline
\end{tabular}




\begin{tabular}{|c|c|c|c|c|c|c|c|}
\hline \multicolumn{8}{|c|}{ Semester Gasal } \\
\hline $\begin{array}{l}\mathbf{N} \\
\mathbf{O}\end{array}$ & NAMA & $\begin{array}{l}\text { KEL } \\
\text { AS }\end{array}$ & $\begin{array}{l}\text { JUAR } \\
\text { A }\end{array}$ & KEGIATAN & $\begin{array}{l}\text { PANITI } \\
\text { A }\end{array}$ & LEVEL & $\begin{array}{l}\text { Wak } \\
\text { tu }\end{array}$ \\
\hline 1 & $\begin{array}{l}\text { Enggar } \\
\text { Putri } \\
\text { Pramesti }\end{array}$ & X IIK & 2 & $\begin{array}{l}\text { POPDA cabang } \\
\text { Bola Voli Pasir } \\
2020\end{array}$ & Dispora & $\begin{array}{l}\text { Kabupat } \\
\text { en }\end{array}$ & $\begin{array}{l}28- \\
\text { Jan- } \\
20\end{array}$ \\
\hline 2 & $\begin{array}{l}\text { Artiani } \\
\text { Ariana } \\
\text { Dewi }\end{array}$ & $\begin{array}{l}\text { X } \\
\text { MIP } \\
\text { A } 4 \\
\end{array}$ & 2 & $\begin{array}{l}\text { POPDA cabang } \\
\text { Bola Voli Pasir } \\
2020\end{array}$ & Dispora & $\begin{array}{l}\text { Kabupat } \\
\text { en }\end{array}$ & $\begin{array}{l}28- \\
\text { Jan- } \\
20 \\
\end{array}$ \\
\hline 3 & $\begin{array}{l}\text { AKBAR } \\
\text { RIZQI } \\
\text { HIDAYAT } \\
\end{array}$ & $\begin{array}{l}\text { XI } \\
\text { MIP } \\
\text { A 2 } \\
\end{array}$ & 2 & $\begin{array}{l}\text { POPDA cabang } \\
\text { Karate Putra } \\
2020 \\
\end{array}$ & Dispora & $\begin{array}{l}\text { Kabupat } \\
\text { en }\end{array}$ & $\begin{array}{l}28- \\
\text { Jan- } \\
20 \\
\end{array}$ \\
\hline 4 & $\begin{array}{l}\text { Wulan } \\
\text { Pebrianti }\end{array}$ & $\begin{array}{l}\text { X IIS } \\
1\end{array}$ & 1 & $\begin{array}{l}\text { POPDA cabang } \\
\text { Karate Putri } \\
2020\end{array}$ & Dispora & $\begin{array}{l}\text { Kabupat } \\
\text { en }\end{array}$ & $\begin{array}{l}28- \\
\text { Jan- } \\
20\end{array}$ \\
\hline 5 & $\begin{array}{l}\text { Nur } \\
\text { Sofiandi }\end{array}$ & $\begin{array}{l}\text { X } \\
\text { MIP } \\
\text { A } 5\end{array}$ & 1 & $\begin{array}{l}\text { POPDA cabang } \\
\text { Taekwondo } \\
\text { Putra Under } \\
53\end{array}$ & Dispora & $\begin{array}{l}\text { Kabupat } \\
\text { en }\end{array}$ & $\begin{array}{l}01- \\
\text { Feb- } \\
20\end{array}$ \\
\hline 6 & $\begin{array}{l}\text { AURA } \\
\text { VERANIS } \\
\text { YAH } \\
\text { SUDART } \\
0\end{array}$ & $\begin{array}{l}\text { XI } \\
\text { MIP } \\
\text { A } 1\end{array}$ & 3 & $\begin{array}{l}\text { POPDA cabang } \\
\text { Taekwondo } \\
\text { Putri Under } 46\end{array}$ & Dispora & $\begin{array}{l}\text { Kabupat } \\
\text { en }\end{array}$ & $\begin{array}{l}01- \\
\text { Feb- } \\
20\end{array}$ \\
\hline 7 & $\begin{array}{l}\text { MAULIDA } \\
\text { KHOLIFA } \\
\text { TUS } \\
\text { ZUHRIYA } \\
\mathrm{H}\end{array}$ & $\begin{array}{l}\text { XI } \\
\text { MIP } \\
\text { A } 1\end{array}$ & 3 & $\begin{array}{l}\text { POPDA cabang } \\
\text { Taekwondo } \\
\text { Putri Under } 48\end{array}$ & Dispora & $\begin{array}{l}\text { Kabupat } \\
\text { en }\end{array}$ & $\begin{array}{l}\text { 01- } \\
\text { Feb- } \\
20\end{array}$ \\
\hline 8 & $\begin{array}{l}\text { NASWA } \\
\text { UZDAH } \\
\text { ALFIYAN } \\
\text { A }\end{array}$ & $\begin{array}{l}\text { XI } \\
\text { MIP } \\
\text { A } 1\end{array}$ & 3 & $\begin{array}{l}\text { POPDA cabang } \\
\text { Taekwondo } \\
\text { Putri Under } 49\end{array}$ & Dispora & $\begin{array}{l}\text { Kabupat } \\
\text { en }\end{array}$ & $\begin{array}{l}01- \\
\text { Feb- } \\
20\end{array}$ \\
\hline 9 & $\begin{array}{l}\text { FEBY } \\
\text { NURMALI } \\
\text { A } \\
\text { HIDAYAT }\end{array}$ & $\begin{array}{l}\text { XI } \\
\text { MIP } \\
\text { A } 1\end{array}$ & 2 & $\begin{array}{l}\text { POPDA cabang } \\
\text { Taekwondo } \\
\text { Putri Under } 52\end{array}$ & Dispora & $\begin{array}{l}\text { Kabupat } \\
\text { en }\end{array}$ & $\begin{array}{l}01- \\
\text { Feb- } \\
20\end{array}$ \\
\hline $\begin{array}{l}1 \\
0\end{array}$ & $\begin{array}{l}\text { UPIK } \\
\text { CATUR } \\
\text { NURUL } \\
\text { HIDAYAH }\end{array}$ & $\begin{array}{l}\text { XI } \\
\text { MIP } \\
\text { A } 1\end{array}$ & 1 & $\begin{array}{l}\text { POPDA cabang } \\
\text { Tenis Meja } \\
\text { Putri }\end{array}$ & Dispora & $\begin{array}{l}\text { Kabupat } \\
\text { en }\end{array}$ & $\begin{array}{l}01- \\
\text { Feb- } \\
20\end{array}$ \\
\hline $\begin{array}{l}1 \\
1\end{array}$ & $\begin{array}{l}\text { RISKI } \\
\text { HARIS } \\
\text { ERLANGG } \\
\text { A }\end{array}$ & $\begin{array}{l}\text { XI } \\
\text { MIP } \\
\text { A } 2\end{array}$ & 2 & $\begin{array}{l}\text { POPDA cabang } \\
\text { pecak silat } \\
\text { kelas C Putra }\end{array}$ & Dispora & $\begin{array}{l}\text { Kabupat } \\
\text { en }\end{array}$ & $\begin{array}{l}02- \\
\text { Feb- } \\
20\end{array}$ \\
\hline $\begin{array}{l}1 \\
2\end{array}$ & $\begin{array}{l}\text { RAFIF } \\
\text { NUR } \\
\text { HIDAYAH } \\
\end{array}$ & $\begin{array}{l}\text { XI } \\
\text { MIP } \\
\text { A 1 } \\
\end{array}$ & 2 & $\begin{array}{l}\text { POPDA cabang } \\
\text { pecak silat } \\
\text { kelas E Putra }\end{array}$ & Dispora & $\begin{array}{l}\text { Kabupat } \\
\text { en }\end{array}$ & $\begin{array}{l}\text { 02- } \\
\text { Feb- } \\
20 \\
\end{array}$ \\
\hline
\end{tabular}


Prestasi Siswa Man 1 Grobogan Di Masa Pandemi Th.Pelajaran 2020/2021

\begin{tabular}{|c|c|c|c|c|c|c|c|c|c|}
\hline $\begin{array}{l}\mathbf{N} \\
\mathbf{o}\end{array}$ & $\begin{array}{l}\text { Nama } \\
\text { Siswa }\end{array}$ & $\begin{array}{l}\text { Kep } \\
\text { eser } \\
\text { Taa } \\
\text { n }\end{array}$ & $\begin{array}{l}\text { Kel } \\
\text { as }\end{array}$ & $\begin{array}{l}\text { Nama } \\
\text { Komp } \\
\text { etisi }\end{array}$ & $\begin{array}{l}\text { Med } \\
\text { ali/ } \\
\text { Juar } \\
\text { a }\end{array}$ & $\begin{array}{l}\text { Ting } \\
\text { kat }\end{array}$ & $\begin{array}{l}\text { Pen } \\
\text { ye } \\
\text { leng } \\
\text { gara }\end{array}$ & $\begin{array}{l}\text { Wa } \\
\text { ktu }\end{array}$ & $\begin{array}{l}\text { Moda } \\
\text { Pelaks } \\
\text { anaan }\end{array}$ \\
\hline 1 & $\begin{array}{l}\text { Hanan } \\
\text { Naufal } \\
\text { Indratma }\end{array}$ & $\begin{array}{l}\text { Indi } \\
\text { vidu }\end{array}$ & $\begin{array}{l}11 \\
\text { MI } \\
\text { PA }\end{array}$ & GMC & $\begin{array}{l}\text { Peru } \\
\text { nggu }\end{array}$ & $\begin{array}{l}\text { Nasio } \\
\text { nal }\end{array}$ & $\begin{array}{l}\text { GENI } \\
0\end{array}$ & $\begin{array}{l}\text { 06- } \\
\text { Jan- } \\
21\end{array}$ & Daring \\
\hline 2 & $\begin{array}{l}\text { Hanan } \\
\text { Naufal } \\
\text { Indratma }\end{array}$ & $\begin{array}{l}\text { Indi } \\
\text { vidu }\end{array}$ & $\begin{array}{l}11 \\
\text { MI } \\
\text { PA }\end{array}$ & $\begin{array}{l}\text { Sains } \\
\text { colled } \\
\text { gee }\end{array}$ & $\begin{array}{l}\text { Pera } \\
\mathrm{k}\end{array}$ & $\begin{array}{l}\text { Nasio } \\
\text { nal }\end{array}$ & $\begin{array}{l}\text { Colle } \\
\text { dge }\end{array}$ & $\begin{array}{l}24- \\
\text { Jan- } \\
21\end{array}$ & Daring \\
\hline 3 & $\begin{array}{l}\text { Dwi ilma } \\
\text { Nuraziza } \\
\text { h }\end{array}$ & $\begin{array}{l}\text { Indi } \\
\text { vidu }\end{array}$ & $\begin{array}{l}10 \\
\text { MI } \\
\text { PA }\end{array}$ & $\begin{array}{l}\text { only } \\
2021\end{array}$ & $\begin{array}{l}\text { Peru } \\
\text { nggu }\end{array}$ & $\begin{array}{l}\text { Nasio } \\
\text { nal }\end{array}$ & POSI & $\begin{array}{l}06- \\
\text { Feb } \\
-21\end{array}$ & Daring \\
\hline 4 & $\begin{array}{l}\text { Dina laily } \\
\text { safitri }\end{array}$ & $\begin{array}{l}\text { Indi } \\
\text { vidu }\end{array}$ & $\begin{array}{l}10 \\
\text { MI } \\
\text { PA }\end{array}$ & $\begin{array}{l}\text { KSI } \\
2021\end{array}$ & $\begin{array}{l}\text { Pera } \\
\mathrm{k}\end{array}$ & $\begin{array}{l}\text { Nasio } \\
\text { nal }\end{array}$ & POSI & $\begin{array}{l}07- \\
\text { Feb } \\
-21\end{array}$ & Daring \\
\hline 5 & $\begin{array}{l}\text { Nila } \\
\text { Puspita } \\
\text { Ariyani }\end{array}$ & $\begin{array}{l}\text { Indi } \\
\text { vidu }\end{array}$ & $\begin{array}{l}10 \\
\text { MI } \\
\text { PA }\end{array}$ & $\begin{array}{l}\text { KSI } \\
2021\end{array}$ & $\begin{array}{l}\text { Peru } \\
\text { nggu }\end{array}$ & $\begin{array}{l}\text { Nasio } \\
\text { nal }\end{array}$ & POSI & $\begin{array}{l}07- \\
\text { Feb } \\
-21\end{array}$ & Daring \\
\hline 6 & $\begin{array}{l}\text { Dini suci } \\
\text { pratiwi }\end{array}$ & $\begin{array}{l}\text { Indi } \\
\text { vidu }\end{array}$ & $\begin{array}{l}10 \\
\mathrm{MI} \\
\mathrm{PA}\end{array}$ & $\begin{array}{l}\text { KSI } \\
2021\end{array}$ & $\begin{array}{l}\text { Peru } \\
\text { nggu }\end{array}$ & $\begin{array}{l}\text { Nasio } \\
\text { nal }\end{array}$ & POSI & $\begin{array}{l}07- \\
\text { Feb } \\
-21\end{array}$ & Daring \\
\hline 7 & $\begin{array}{l}\text { Jannatul } \\
\text { Aulya } \\
\text { Rahmaw } \\
\text { ati }\end{array}$ & $\begin{array}{l}\text { Indi } \\
\text { vidu }\end{array}$ & $\begin{array}{l}10 \\
\mathrm{MI} \\
\mathrm{PA}\end{array}$ & $\begin{array}{l}\text { KSI } \\
2021\end{array}$ & $\begin{array}{l}\text { Peru } \\
\text { nggu }\end{array}$ & $\begin{array}{l}\text { Nasio } \\
\text { nal }\end{array}$ & POSI & $\begin{array}{l}07- \\
\text { Feb } \\
-21\end{array}$ & Daring \\
\hline 8 & $\begin{array}{l}\text { MIRA } \\
\text { DWI } \\
\text { INDAH } \\
\text { AINI }\end{array}$ & $\begin{array}{l}\text { Indi } \\
\text { vidu }\end{array}$ & $\begin{array}{l}10 \\
\text { MI } \\
\text { PA }\end{array}$ & $\begin{array}{l}\text { KSI } \\
2021\end{array}$ & $\begin{array}{l}\text { Pera } \\
\mathrm{k}\end{array}$ & $\begin{array}{l}\text { Nasio } \\
\text { nal }\end{array}$ & POSI & $\begin{array}{l}07- \\
\text { Feb } \\
-21\end{array}$ & Daring \\
\hline 9 & $\begin{array}{l}\text { REVA } \\
\text { AMAND } \\
\text { A }\end{array}$ & $\begin{array}{l}\text { Indi } \\
\text { vidu }\end{array}$ & $\begin{array}{l}10 \\
\text { MI } \\
\text { PA }\end{array}$ & $\begin{array}{l}\text { FPOK } \\
\text { KSI }\end{array}$ & $\begin{array}{l}\text { Pera } \\
\mathrm{k}\end{array}$ & $\begin{array}{l}\text { Nasio } \\
\text { nal }\end{array}$ & $\begin{array}{l}\text { FOK } \\
\text { SI }\end{array}$ & $\begin{array}{l}14- \\
\text { Feb } \\
-21\end{array}$ & Daring \\
\hline $\begin{array}{l}1 \\
0\end{array}$ & $\begin{array}{l}\text { Hanan } \\
\text { Naufal } \\
\text { Indratma }\end{array}$ & $\begin{array}{l}\text { Indi } \\
\text { vidu }\end{array}$ & $\begin{array}{l}11 \\
\text { MI } \\
\text { PA }\end{array}$ & $\begin{array}{l}\text { OMN } \\
2021\end{array}$ & $\begin{array}{l}\text { Ema } \\
s\end{array}$ & $\begin{array}{l}\text { Nasio } \\
\text { nal }\end{array}$ & $\begin{array}{l}\text { FOT } \\
\text { ON }\end{array}$ & $\begin{array}{l}14- \\
\text { Feb } \\
-21\end{array}$ & Daring \\
\hline $\begin{array}{l}1 \\
1\end{array}$ & $\begin{array}{l}\text { Atsbit } \\
\text { Naila } \\
\text { salsabila }\end{array}$ & $\begin{array}{l}\text { Indi } \\
\text { vidu }\end{array}$ & $\begin{array}{l}10 \\
\text { MI } \\
\text { PA }\end{array}$ & $\begin{array}{l}\text { FPOK } \\
\text { KSI }\end{array}$ & $\begin{array}{l}\text { Pera } \\
\mathrm{k}\end{array}$ & $\begin{array}{l}\text { Nasio } \\
\text { nal }\end{array}$ & $\begin{array}{l}\text { FOK } \\
\text { SI }\end{array}$ & $\begin{array}{c}14- \\
\text { Feb } \\
-21\end{array}$ & Daring \\
\hline $\begin{array}{l}1 \\
2\end{array}$ & $\begin{array}{l}\text { Hanan } \\
\text { Naufal }\end{array}$ & $\begin{array}{l}\text { Indi } \\
\text { vidu }\end{array}$ & $\begin{array}{l}11 \\
\text { MI }\end{array}$ & $\begin{array}{l}\text { KSI } \\
2021\end{array}$ & $\begin{array}{l}\text { Pera } \\
\mathrm{k}\end{array}$ & $\begin{array}{l}\text { Nasio } \\
\text { nal }\end{array}$ & POSI & $\begin{array}{l}24- \\
\text { Feb }\end{array}$ & Daring \\
\hline
\end{tabular}




\begin{tabular}{|c|c|c|c|c|c|c|c|c|c|}
\hline & Indratma & & PA & & & & & -21 & \\
\hline $\begin{array}{l}1 \\
3\end{array}$ & $\begin{array}{l}\text { Dini suci } \\
\text { pratiwi }\end{array}$ & $\begin{array}{l}\text { Indi } \\
\text { vidu }\end{array}$ & $\begin{array}{l}10 \\
\text { MI } \\
\text { PA } \\
6\end{array}$ & $\begin{array}{l}\text { KSI } \\
2021 \\
\text { BIOLO } \\
\text { GI }\end{array}$ & $\begin{array}{l}\text { Pera } \\
\mathrm{k}\end{array}$ & $\begin{array}{l}\text { Nasio } \\
\text { nal }\end{array}$ & POSI & $\begin{array}{l}21- \\
\text { Feb } \\
-21\end{array}$ & Daring \\
\hline $\begin{array}{l}1 \\
4\end{array}$ & $\begin{array}{l}\text { Atsbit } \\
\text { Naila } \\
\text { salsabila }\end{array}$ & $\begin{array}{l}\text { Indi } \\
\text { vidu }\end{array}$ & $\begin{array}{l}10 \\
\text { MI } \\
\text { PA }\end{array}$ & $\begin{array}{l}\text { KSI } \\
2021 \\
\text { MTK }\end{array}$ & $\begin{array}{l}\text { Peru } \\
\text { nggu }\end{array}$ & $\begin{array}{l}\text { Nasio } \\
\text { nal }\end{array}$ & POSI & $\begin{array}{l}21- \\
\text { Feb } \\
-21\end{array}$ & Daring \\
\hline $\begin{array}{l}1 \\
5\end{array}$ & $\begin{array}{l}\text { Maulidat } \\
\text { uzzahro }\end{array}$ & $\begin{array}{l}\text { Indi } \\
\text { vidu }\end{array}$ & $\begin{array}{l}11 \\
\text { MI } \\
\text { PA } \\
2\end{array}$ & $\begin{array}{l}\text { Sainst } \\
\text { ek }\end{array}$ & $\begin{array}{l}\text { Peru } \\
\text { nggu }\end{array}$ & $\begin{array}{l}\text { Nasio } \\
\text { nal }\end{array}$ & POSI & $\begin{array}{l}21- \\
\text { Feb } \\
-21\end{array}$ & Daring \\
\hline $\begin{array}{l}1 \\
6\end{array}$ & $\begin{array}{l}\text { Dini suci } \\
\text { pratiwi }\end{array}$ & $\begin{array}{l}\text { Indi } \\
\text { vidu }\end{array}$ & $\begin{array}{l}10 \\
\text { MI } \\
\text { PA } \\
6\end{array}$ & $\begin{array}{l}\text { Sainst } \\
\text { ek }\end{array}$ & $\begin{array}{l}\text { Pera } \\
\mathrm{k}\end{array}$ & $\begin{array}{l}\text { Nasio } \\
\text { nal }\end{array}$ & POSI & $\begin{array}{l}21- \\
\text { Feb } \\
-21\end{array}$ & Daring \\
\hline $\begin{array}{l}1 \\
4\end{array}$ & $\begin{array}{l}\text { Hanum } \\
\text { salsabila }\end{array}$ & $\begin{array}{l}\text { Indi } \\
\text { vidu }\end{array}$ & $\begin{array}{l}10 \\
\text { MI } \\
\text { PA }\end{array}$ & $\begin{array}{l}\text { Sainst } \\
\text { ek }\end{array}$ & $\begin{array}{l}\text { Peru } \\
\text { nggu }\end{array}$ & $\begin{array}{l}\text { Nasio } \\
\text { nal }\end{array}$ & POSI & $\begin{array}{l}21- \\
\text { Feb } \\
-21\end{array}$ & Daring \\
\hline $\begin{array}{l}1 \\
5\end{array}$ & $\begin{array}{l}\text { Galuh } \\
\text { salwa }\end{array}$ & $\begin{array}{l}\text { Indi } \\
\text { vidu }\end{array}$ & $\begin{array}{l}11 \\
\text { MI } \\
\text { PA } \\
2\end{array}$ & $\begin{array}{l}\text { Sainst } \\
\text { ek }\end{array}$ & $\begin{array}{l}\text { Peru } \\
\text { nggu }\end{array}$ & $\begin{array}{l}\text { Nasio } \\
\text { nal }\end{array}$ & POSI & $\begin{array}{l}21- \\
\text { Feb } \\
-21\end{array}$ & Daring \\
\hline $\begin{array}{l}1 \\
6\end{array}$ & $\begin{array}{l}\text { Abilia } \\
\text { dwi } \\
\text { ananta }\end{array}$ & $\begin{array}{l}\text { Indi } \\
\text { vidu }\end{array}$ & $\begin{array}{l}10 \\
\text { MI } \\
\text { PA } \\
6\end{array}$ & $\begin{array}{l}\text { Sainst } \\
\text { ek }\end{array}$ & $\begin{array}{l}\text { Pera } \\
\mathrm{k}\end{array}$ & $\begin{array}{l}\text { Nasio } \\
\text { nal }\end{array}$ & POSI & $\begin{array}{l}21- \\
\text { Feb } \\
-21\end{array}$ & Daring \\
\hline $\begin{array}{l}1 \\
7\end{array}$ & $\begin{array}{l}\text { Dini suci } \\
\text { pratiwi }\end{array}$ & $\begin{array}{l}\text { Indi } \\
\text { vidu }\end{array}$ & $\begin{array}{l}10 \\
\text { MI } \\
\text { PA } \\
6\end{array}$ & $\begin{array}{l}\text { Posi } \\
\text { Got } \\
\text { Talent }\end{array}$ & $\begin{array}{l}\text { Pera } \\
\mathrm{k}\end{array}$ & $\begin{array}{l}\text { Nasio } \\
\text { nal }\end{array}$ & POSI & $\begin{array}{l}21- \\
\text { Feb } \\
-21\end{array}$ & Daring \\
\hline $\begin{array}{l}1 \\
8\end{array}$ & $\begin{array}{l}\text { Atsbit } \\
\text { Naila } \\
\text { salsabila }\end{array}$ & $\begin{array}{l}\text { Indi } \\
\text { vidu }\end{array}$ & $\begin{array}{l}10 \\
\mathrm{MI} \\
\mathrm{PA}\end{array}$ & $\begin{array}{l}\text { Posi } \\
\text { Got } \\
\text { Talent }\end{array}$ & $\begin{array}{l}\text { Peru } \\
\text { nggu }\end{array}$ & $\begin{array}{l}\text { Nasio } \\
\text { nal }\end{array}$ & POSI & $\begin{array}{l}21- \\
\text { Feb } \\
-21\end{array}$ & Daring \\
\hline $\begin{array}{l}1 \\
9\end{array}$ & $\begin{array}{l}\text { Hanif } \\
\text { Fikri } \\
\text { Irfansya } \\
\text { h }\end{array}$ & Tim & $\begin{array}{l}10 \\
\text { MI } \\
\text { PA } \\
2 \\
\end{array}$ & $\begin{array}{l}\text { ROBO } \\
\text { TIK }\end{array}$ & $\begin{array}{l}\text { Bron } \\
\text { ze } \\
\text { Med } \\
\text { al } \\
\end{array}$ & $\begin{array}{l}\text { Nasio } \\
\text { nal }\end{array}$ & $\begin{array}{l}\text { KRO } \\
\mathrm{N}\end{array}$ & $\begin{array}{l}14- \\
\mathrm{Ma} \\
\mathrm{r}- \\
21 \\
\end{array}$ & Daring \\
\hline $\begin{array}{l}2 \\
0\end{array}$ & $\begin{array}{l}\text { Nilam } \\
\text { DwiA'ida } \\
\text { h F. }\end{array}$ & Tim & $\begin{array}{l}10 \\
\text { MI } \\
\text { PA } \\
2 \\
\end{array}$ & $\begin{array}{l}\text { ROBO } \\
\text { TIK }\end{array}$ & $\begin{array}{l}\text { Bron } \\
\text { ze } \\
\text { Med } \\
\text { al } \\
\end{array}$ & $\begin{array}{l}\text { Nasio } \\
\text { nal }\end{array}$ & $\begin{array}{l}\text { KRO } \\
\mathrm{N}\end{array}$ & $\begin{array}{l}14- \\
\mathrm{Ma} \\
\mathrm{r}- \\
21 \\
\end{array}$ & Daring \\
\hline 2 & Puput & Tim & 10 & ROBO & Bron & Nasio & KRO & $14-$ & Daring \\
\hline
\end{tabular}




\begin{tabular}{|c|c|c|c|c|c|c|c|c|c|}
\hline 1 & Agustin & & $\begin{array}{l}\mathrm{Mi} \\
\text { pa } \\
5\end{array}$ & TIK & $\begin{array}{l}\text { ze } \\
\text { Med } \\
\text { al }\end{array}$ & nal & $\mathrm{N}$ & $\begin{array}{l}\text { Ma } \\
\text { r- } \\
21\end{array}$ & \\
\hline $\begin{array}{l}2 \\
2\end{array}$ & $\begin{array}{l}\text { Maulidat } \\
\text { uzzahro }\end{array}$ & $\begin{array}{l}\text { Indi } \\
\text { vidu }\end{array}$ & $\begin{array}{l}11 \\
\mathrm{MI} \\
\mathrm{PA} \\
2\end{array}$ & $\begin{array}{l}\text { Sainst } \\
\text { ek }\end{array}$ & $\begin{array}{l}\text { Pera } \\
\mathrm{k}\end{array}$ & $\begin{array}{l}\text { Nasio } \\
\text { nal }\end{array}$ & $\begin{array}{l}\text { MOC } \\
2\end{array}$ & $\begin{array}{l}28- \\
\text { Ma } \\
\text { r- } \\
21\end{array}$ & Daring \\
\hline $\begin{array}{l}2 \\
3\end{array}$ & $\begin{array}{l}\text { Aqila } \\
\text { Malquina }\end{array}$ & $\begin{array}{l}\text { Indi } \\
\text { vidu }\end{array}$ & $\begin{array}{l}11 \\
\text { MI } \\
\text { PA } \\
2\end{array}$ & $\begin{array}{l}\text { Sainst } \\
\text { ek }\end{array}$ & $\begin{array}{l}\text { Hora } \\
\text { ble } \\
\text { Ment } \\
\text { ion }\end{array}$ & $\begin{array}{l}\text { Nasio } \\
\text { nal }\end{array}$ & $\begin{array}{l}\text { MOC } \\
2\end{array}$ & $\begin{array}{l}28- \\
\text { Ma } \\
\text { r- } \\
21\end{array}$ & Daring \\
\hline $\begin{array}{l}2 \\
4 \\
\end{array}$ & $\begin{array}{l}\text { TIM } \\
\text { KOPBAR } \\
\text { A } \\
\end{array}$ & Tim & $\begin{array}{l}X \\
\text { dan } \\
1 X \\
\end{array}$ & $\begin{array}{l}\text { Prokla } \\
\text { mator } \\
\text { jawa } \\
\text { open } \\
\end{array}$ & $\begin{array}{l}\text { Uta } \\
\text { ma Ii }\end{array}$ & Jawa & $\begin{array}{l}\text { SMA } \\
1 \\
\text { Blita } \\
\mathrm{r} \\
\end{array}$ & $\begin{array}{l}11- \\
\text { Apr } \\
-21\end{array}$ & Daring \\
\hline $\begin{array}{l}2 \\
5\end{array}$ & $\begin{array}{l}\text { Aqila } \\
\text { Malquina }\end{array}$ & $\begin{array}{l}\text { Indi } \\
\text { vidu }\end{array}$ & $\begin{array}{l}11 \\
\text { MI } \\
\text { PA } \\
2\end{array}$ & $\begin{array}{l}\text { Hardik } \\
\text { nas } \\
\text { Post } \\
\text { Biologi }\end{array}$ & $\begin{array}{l}\text { Bron } \\
\text { ze } \\
\text { Med } \\
\text { al }\end{array}$ & $\begin{array}{l}\text { Nasio } \\
\text { nal }\end{array}$ & POSI & $\begin{array}{l}09- \\
\text { Ma } \\
\text { y- } \\
21\end{array}$ & Daring \\
\hline $\begin{array}{l}2 \\
6 \\
\end{array}$ & $\begin{array}{l}\text { M.Muhsi } \\
\mathrm{n} \\
\text { Alfayyad } \\
\text { h }\end{array}$ & $\begin{array}{l}\text { Indi } \\
\text { vidu }\end{array}$ & $\begin{array}{l}11 \\
\text { MI } \\
\text { PA } \\
2 \\
\end{array}$ & $\begin{array}{l}\text { Hardik } \\
\text { nas } \\
\text { Post } \\
\text { Biologi } \\
\end{array}$ & $\begin{array}{l}\text { Bron } \\
\text { ze } \\
\text { Med } \\
\text { al } \\
\end{array}$ & $\begin{array}{l}\text { Nasio } \\
\text { nal }\end{array}$ & POSI & $\begin{array}{l}09- \\
\mathrm{Ma} \\
\mathrm{y}^{-} \\
21 \\
\end{array}$ & Daring \\
\hline $\begin{array}{l}2 \\
7\end{array}$ & $\begin{array}{l}\text { Nilam } \\
\text { dwi } \\
\text { A'idah } \\
\text { Faridah }\end{array}$ & $\begin{array}{l}\text { Indi } \\
\text { vidu }\end{array}$ & $\begin{array}{l}11 \\
\text { MI } \\
\text { PA } \\
2\end{array}$ & $\begin{array}{l}\text { Hardik } \\
\text { nas } \\
\text { Post } \\
\text { Biologi }\end{array}$ & $\begin{array}{l}\text { Bron } \\
\text { ze } \\
\text { Med } \\
\text { al }\end{array}$ & $\begin{array}{l}\text { Nasio } \\
\text { nal }\end{array}$ & POSI & $\begin{array}{l}09- \\
\text { Ma } \\
\text { y- } \\
21\end{array}$ & Daring \\
\hline $\begin{array}{l}2 \\
8\end{array}$ & $\begin{array}{l}\text { Hanan } \\
\text { Naufal } \\
\text { Indratma }\end{array}$ & $\begin{array}{l}\text { Indi } \\
\text { vidu }\end{array}$ & $\begin{array}{l}1 \\
\text { MI } \\
\text { PA } \\
2\end{array}$ & $\begin{array}{l}\text { KMS } \\
16\end{array}$ & $\begin{array}{l}\text { Cred } \\
\text { it } \\
\text { Kela } \\
\text { s2 }\end{array}$ & $\begin{array}{l}\text { Nasio } \\
\text { nal }\end{array}$ & KPM & $\begin{array}{l}04- \\
\text { Jun } \\
-21\end{array}$ & Daring \\
\hline $\begin{array}{l}2 \\
9\end{array}$ & $\begin{array}{l}\text { Fedhila } \\
\text { fieldhata } \\
\text { ma }\end{array}$ & $\begin{array}{l}\text { Indi } \\
\text { vidu }\end{array}$ & $\begin{array}{l}11 \\
\text { MI } \\
\text { PA } \\
2\end{array}$ & IKMC & $\begin{array}{l}\text { Hora } \\
\text { ble } \\
\text { Ment } \\
\text { ion }\end{array}$ & $\begin{array}{l}\text { Nasio } \\
\text { nal }\end{array}$ & KPM & $\begin{array}{l}06- \\
\text { Ma } \\
\text { y- } \\
21\end{array}$ & Daring \\
\hline $\begin{array}{l}3 \\
0\end{array}$ & $\begin{array}{l}\text { Fedhila } \\
\text { fieldhata } \\
\text { ma }\end{array}$ & $\begin{array}{l}\text { Indi } \\
\text { vidu }\end{array}$ & $\begin{array}{l}11 \\
\text { MI } \\
\text { PA } \\
2 \\
\end{array}$ & IKMC & $\begin{array}{l}\text { Hora } \\
\text { ble } \\
\text { Ment } \\
\text { ion }\end{array}$ & $\begin{array}{l}\text { Nasio } \\
\text { nal }\end{array}$ & KPM & $\begin{array}{l}27- \\
\mathrm{Ma} \\
\mathrm{r}- \\
21\end{array}$ & Daring \\
\hline $\begin{array}{l}3 \\
1 \\
\end{array}$ & $\begin{array}{l}\text { M.Muhsi } \\
\mathrm{n} \\
\text { Alfayyad } \\
\mathrm{h}\end{array}$ & $\begin{array}{l}\text { Indi } \\
\text { vidu }\end{array}$ & $\begin{array}{l}11 \\
\text { MI } \\
\text { PA } \\
2 \\
\end{array}$ & PPSM & $\begin{array}{l}\text { Peru } \\
\text { nggu }\end{array}$ & $\begin{array}{l}\text { Nasio } \\
\text { nal }\end{array}$ & KSIH & $\begin{array}{l}26- \\
\text { Apr } \\
-21\end{array}$ & Daring \\
\hline 3 & Dhila & Indi & 11 & Pramu & 3 & Kabu & Kwa & $23-$ & Datang \\
\hline
\end{tabular}




\begin{tabular}{|c|c|c|c|c|c|c|c|c|c|}
\hline 2 & $\begin{array}{l}\text { Amelia } \\
\text { Rahma }\end{array}$ & vidu & $\begin{array}{l}\text { MI } \\
\text { PA } \\
2\end{array}$ & $\begin{array}{l}\text { ka } \\
\text { Garud } \\
\text { a }\end{array}$ & & paten & rcab & $\begin{array}{l}\text { Jun } \\
-21\end{array}$ & Lokasi \\
\hline $\begin{array}{l}3 \\
3\end{array}$ & $\begin{array}{l}\text { Syafiatul } \\
\text { Adhimah }\end{array}$ & $\begin{array}{l}\text { Indi } \\
\text { vidu }\end{array}$ & $\begin{array}{l}11 \\
\text { MI } \\
\text { PA } \\
1\end{array}$ & KSM-O & $\begin{array}{l}\text { Silve } \\
r \\
\text { MED } \\
\text { AL }\end{array}$ & $\begin{array}{l}\text { Nasio } \\
\text { nal }\end{array}$ & POSI & $\begin{array}{l}20- \\
\text { Jun } \\
-21\end{array}$ & Daring \\
\hline $\begin{array}{l}3 \\
4\end{array}$ & $\begin{array}{l}\text { Dwi ilma } \\
\text { NurAziza } \\
\text { h }\end{array}$ & $\begin{array}{l}\text { Indi } \\
\text { vidu }\end{array}$ & $\begin{array}{l}10 \\
\text { MI } \\
\text { PA } \\
3\end{array}$ & KSM-O & $\begin{array}{l}\text { Bron } \\
\text { ze } \\
\text { Med } \\
\text { al }\end{array}$ & $\begin{array}{l}\text { Nasio } \\
\text { nal }\end{array}$ & POSI & $\begin{array}{l}20- \\
\text { Jun } \\
-21\end{array}$ & Daring \\
\hline $\begin{array}{l}3 \\
5 \\
\end{array}$ & $\begin{array}{l}\text { Dini suci } \\
\text { pratiwi }\end{array}$ & $\begin{array}{l}\text { Indi } \\
\text { vidu }\end{array}$ & $\begin{array}{l}10 \\
\text { MI } \\
\text { PA } \\
6 \\
\end{array}$ & KSM-O & $\begin{array}{l}\text { Bron } \\
\text { ze } \\
\text { Med } \\
\text { al } \\
\end{array}$ & $\begin{array}{l}\text { Nasio } \\
\text { nal }\end{array}$ & POSI & $\begin{array}{l}20- \\
\text { Jun } \\
-21\end{array}$ & Daring \\
\hline $\begin{array}{l}3 \\
6\end{array}$ & $\begin{array}{l}\text { Hanan } \\
\text { Naufal } \\
\text { Indratma }\end{array}$ & $\begin{array}{l}\text { Indi } \\
\text { vidu }\end{array}$ & $\begin{array}{l}11 \\
\text { MI } \\
\text { PA } \\
2\end{array}$ & $\begin{array}{l}\text { KSN } \\
\text { Kabup } \\
\text { aten }\end{array}$ & 1 & $\begin{array}{l}\text { Kabu } \\
\text { paten }\end{array}$ & KSN & $\begin{array}{l}3-4 \\
\text { juni } \\
202 \\
1\end{array}$ & Daring \\
\hline $\begin{array}{l}3 \\
7\end{array}$ & $\begin{array}{l}\text { Hanan } \\
\text { Naufal } \\
\text { Indratma }\end{array}$ & $\begin{array}{l}\text { Indi } \\
\text { vidu }\end{array}$ & $\begin{array}{l}11 \\
\text { MI } \\
\text { PA } \\
2\end{array}$ & KSMO & 1 & $\begin{array}{l}\text { Propi } \\
\text { nsi }\end{array}$ & POSI & $\begin{array}{l}20- \\
\text { Jun } \\
-21\end{array}$ & Daring \\
\hline $\begin{array}{l}3 \\
8\end{array}$ & $\begin{array}{l}\text { Dhila } \\
\text { Amelia } \\
\text { Rahma }\end{array}$ & $\begin{array}{l}\text { Indi } \\
\text { vidu }\end{array}$ & $\begin{array}{l}11 \\
\text { MI } \\
\text { PA } \\
2\end{array}$ & $\begin{array}{l}\text { Pramu } \\
\text { ka } \\
\text { Garud } \\
\text { a }\end{array}$ & 3 & $\begin{array}{l}\text { Kabu } \\
\text { paten }\end{array}$ & $\begin{array}{l}\text { kwar } \\
\text { cab }\end{array}$ & $\begin{array}{l}23- \\
\text { Jun } \\
-21\end{array}$ & $\begin{array}{l}\text { Datang } \\
\text { Keloka } \\
\text { si }\end{array}$ \\
\hline $\begin{array}{l}3 \\
9\end{array}$ & $\begin{array}{l}\text { Emi } \\
\text { kumalas } \\
\text { ari }\end{array}$ & $\begin{array}{l}\text { Indi } \\
\text { vidu }\end{array}$ & $\begin{array}{l}11 \\
\text { IPS } \\
2\end{array}$ & NSO & $\begin{array}{l}\text { Peru } \\
\text { nggu }\end{array}$ & $\begin{array}{l}\text { Nasio } \\
\text { nal }\end{array}$ & ISN & $\begin{array}{l}27- \\
\text { Jun } \\
-21\end{array}$ & Daring \\
\hline $\begin{array}{l}4 \\
0\end{array}$ & Ernawati & $\begin{array}{l}\text { Indi } \\
\text { vidu }\end{array}$ & $\begin{array}{l}11 \\
\text { IPS } \\
4\end{array}$ & NSO & $\begin{array}{l}\text { Peru } \\
\text { nggu }\end{array}$ & $\begin{array}{l}\text { Nasio } \\
\text { nal }\end{array}$ & ISN & $\begin{array}{l}27- \\
\text { Jun } \\
-21\end{array}$ & Daring \\
\hline $\begin{array}{l}5 \\
0\end{array}$ & $\begin{array}{l}\text { Aqila } \\
\text { Malquina }\end{array}$ & $\begin{array}{l}\text { Indi } \\
\text { vidu }\end{array}$ & $\begin{array}{l}12 \\
\text { Ipa } \\
2\end{array}$ & ios & $\begin{array}{l}\text { Peru } \\
\text { nggu }\end{array}$ & $\begin{array}{l}\text { Nasio } \\
\text { nal }\end{array}$ & posi & $\begin{array}{l}27- \\
\text { Jun } \\
-21\end{array}$ & Daring \\
\hline
\end{tabular}

Berdasarkan data perolehan prestasi siswa MAN 1 Grobogan sebagaimana telah ditorehkan diatas, maka tidak ada alasan bagi pelajar lain di daerah lain baik di tingkat SD $<$ SLTP, SLTA maupun perguruan tinggi untuk tetap mencetak prestasi agar tetap semangat dan termotivasi meski pembelajaran secara daring. Untuk dapat 
mewujudkan prestasi meski di masa pandemic, berikut ini penulis rangkumkan tulisan dari Sekretaris Jenderal Ikatan Alumni (IKA) Institut Teknologi Sepuluh Nopember (ITS) Surabaya, Thonthowi Djauhari beberapa tips jitu agar tetap berprestasi selama pembelajaran online tetap dilakukan antara lain:

1. Maksimalkan piranti pendukung Ada berbagai tantangan saat mengikuti kegiatan belajar di rumah masing-masing. Termasuk sarana dan prasarana untuk mengikuti pembelajaran online. pendukung. sebisa mungkin pihak sekolah membantu mereka dalam menyediakan fasilitas yang memadai apabila memiliki keterbatasan piranti. Salah satunya dengan bekerjasama dengan berbagai pihak untuk memberikan bantuan kepada pelajar yang membutuhkan. Hal ini bertujuan agar mereka tetap bisa mengikuti kegiatan belajar mengajar secara online. "Jika semua pelajar atau mahasiswa memiliki fasilitas memadai, dapat dipastikan mereka bisa melakukan kegiatan belajar mengajar.

2. Meningkatkan soft skill Keahlian seseorang tidak bisa hanya dilihat dari kemampuan mereka dalam memahami pelajaran atau dari sisi akademik saja. Namun, mereka juga harus dibekali dengan kemampuan soft skill yang baik. Ini diperlukan agar bisa berkarya setelah lulus nanti. Terlebih soft skill sangat dibutuhkan ketika memasuki dunia kerja. Meskipun berada di situasi pandemi, soft skill tetap bisa diasah dengan mengikuti kegiatan sekolah meskipun hanya melalui daring. "Dengan tetap berorganisasi, maka bisa mengasah kemampuan 
mengutarakan ide dengan baik, memimpin dan dipimpin serta bekerja dalam tim.

3. Berdiskusi untuk menambah wawasan Selain belajar dari guru materi pembelajaran bisa ditambah dengan melakukan diskusi. Bisa dengan teman sekelas, video yang bisa menjadi bahan diskusi untuk menambah wawasan.

4. Mempelajari cara berprestasi seseorang Salah satu cara yang mudah untuk tetap berprestasi adalah dengan mendapatkan inspirasi dari orang-orang yang berprestasi. Hal ini bisa dilakukan dengan cara membaca buku biografi orang - orang sukses atau menonton perjalanan karier seseorang.

5. Jangan takut gagal karena kegagalan adalah hal yang biasa bagi seseorang yang melakukan suatu pekerjaan. Lebih baik melakukan sesuatu meski harus mengalami kegagalan terlebih dahulu. "Dari kegagalan itu, bisa belajar apa penyebab kegagalannya. Sehingga kita tidak akan mengulangi kegagalan tersebut. Jika hal tersebut konsisten dilakukan saat menjalani pembelajaran online, baik pelajar maupun mahasiswa tetap bisa meraih prestasi di masa pandemi seperti saat ini.

Yang terpenting dalam hidup ini adalah teruslah berprestasi dan berlomba dalam kebaikan sebagaimana dianjurkan dalam sebuah hadist "Fastabiqul Khoirot" (Kompas.com) 


\title{
MOTIVASI BELAJAR MAHASISWA PADA MASA PANDEMI COVID-19
}

\author{
Silvi Aryanti, M.Pd ${ }^{9}$ \\ Universitas Sriwijaya
}

"Mulai memberikan dorongan terhadap diri, memanfaatkan apa yang dimiliki, melakukan apa yang dikuasai adalah kunci untuk membakar semangat belajar di masa pandemi"

\section{Pendahuluan}

Wabah covid-19 telah masuk pada tahun kedua yang dilanda oleh masyarakat di seluruh dunia begitu juga dengan negara Indonesia. Adanya wabah covid-19 memberikan dampak khususnya pada dunia pendidikan. Pendidikan yang dilakukan secara daring di Indonesia sudah dilaksanakan surat edaran Nomor 4 tahun 2020 oleh Menteri Pendidikan dan Kebudayaan Republik Indonesia tentang proses belajar yang dilakukan rumah masingmasing. Argaheni (2020) sejak 16 maret 2020 kegiatan belajar dilakukan dari rumah dan tidak diwajibkan untuk datang ke sekolah.

${ }^{9}$ Penulis lahir di Palembang, 21 Juli 1991, penulis merupakan Dosen Program Studi Pendidikan Jasmani, Kesehatan, dan Rekreasi Fakultas Keguruan dan Ilmu Pendidikan Universitas Sriwijaya, penulis menyelesaikan gelar Sarjana Pendidikan Prodi Penjaskes di FKIP Universitas Sriwijaya (2012), dan menyelesaikan gelar magister di Universitas Negeri Yogyakarta Ilmu Keolahragaan Konsentrasi Pendidikan Olahraga (2015). 
Semua jenjang pendidikan baik sekolah dasar, sekolah menengah pertama, sekolah menengah atas, dan juga perguruan tinggi. Perkuliahan secara daring dilakukan pada Perguruan tinggi. Hal ini bertujuan untuk menekan bertambahnya yang terkena covid-19 juga dikarenakan mahasiswa berasal dari berbagai provinsi. Sahu (2020) Persoalan multidimensi yang dihadapi dunia dengan adanya pandemi Covid-19, sehingga muncul permasalahan khususnya dalam bidang pendidikan yakni kualitas belajar pada peserta didik menurun.

Perkuliahan yang dilakukan oleh mahasiswa selama pandemi covid-19 berkaitan dengan motivasi belajar. Uno (2016) motivasi belajar dibagi menjadi dua faktor yaitu faktor intrinsik dan faktor ekstrinsik. Faktor instrinsik yaitu hasrat dan keinginan untuk berhasil, dorongan kebutuhan belajar, kegiatan belajar yang menarik dan lingkungan belajar yang kondusif. Faktor ekstrinsik yaitu penghargaan, kegiatan belajar yang menarik dan lingkungan belajar yang kondusif. Nasrah \& Muafiah (2020) dengan motivasi belajar yang tinggi, maka dapat membuat mahasiswa hasil belajar yang baik diperoleh. Hasil penelitian Fitriyani, Fauzi, \& Sari (2020) didapatkan motivasi belajar yaitu sangat baik pada mahasiswa semester 6 program studi pendidikan guru sekolah dasar di Universitas Kuningan. Hal ini berdasarkan skor presentase motivasi yaitu 80,27 \%. Oleh sebab itu, motivasi belajar baik intrinsik maupun ekstrinsik pada masa pandemi covid-19 sangatlah penting untuk mencapai hasil tujuan pembelajaran.

\section{Pembahasan}

Keberhasilan dalam pembelajaran daring didukung dengan motivasi belajar sehingga perlu dipertimbangkan motivasi belajar di lingkungan belajar yang pemanfaatan 
teknologi (Harandi, 2015). Motivasi belajar merupakan dorongan yang dapat membuat seseorang tertarik untuk mengikuti pembelajaran. Hal ini membuat seseorang akan terus mengikuti belajar. Motivasi yang rendah dapat berpengaruh terhadap keberhasilan dalam belajar sehingga prestasi belajar menurun.

Pembelajaran yang dilakukan daring memiliki pengaruh positif khususnya motivasi belajar mahasiswa selama masa Pandemi Covid-19 (Sur, Hasanah \& Mustofa, 2020). Hasil penelitian diperoleh tingkat minat belajar ikut dalam perkuliahan daring pada mahasiswa pendidikan ekonomi Universitas Ekasakti yaitu 62,87\% termasuk pada kategori cukup baik (Gumanti \& Teza, 2021). Hasil wawancara memperoleh mahasiswa termotivasi untuk perkuliahan secara daring diikuti. Hal ini dikarenakan adanya dukungan orangtua dan perhatian agar kuota internet terpenuhi (Rosa, 2020).

Berdasarkan hasil penelitian yang relevan dapat dilihat bahwa mahasiswa termotivasi dalam mengikuti pembelajaran selama masa pandemi covid 19. Hal ini dikarenakan adanya dukungan dari orang tua yang menyediakan kuota internet. Walaupun belajar dilakukan dirumah, membuat mahasiswa termotivasi agar tidak bermalas-malasan dan tetap semangat dengan tugas yang diberikan oleh dosen.

\section{Penutup}

Faktor yang dapat mendukung pembelajaran yaitu dengan adanya motivasi belajar dari mahasiswa. Walaupun pembelajaran dilakukan secara daring, tidak mengubah motivasi belajar. Motivasi belajar dapat dipengaruhi juga dengan situasi dan kondisi. 


\section{Daftar Pustaka}

Argaheni, N. B. (2020) 'Sistematik Review: Dampak Perkuliahan Daring Saat Pandemi COVID-19 Terhadap Mahasiswa Indonesia', PLACENTUM: Jurnal Ilmiah Kesehatan dan Aplikasinya, 8(2), p. 99. doi: 10.20961/placentum.v8i2.43008.

Fitriyani, Y., Fauzi, I., \& Sari, M. Z. (2020). Motivasi belajar mahasiswa pada pembelajaran daring selama pandemik covid-19.Jurnal Kependidikan: Jurnal Hasil Penelitian dan Kajian Kepustakaan di Bidang Pendidikan, Pengajaran dan Pembelajaran, 6(2), 165-175.

Gumanti, D., \& Teza, S. D. (2021). Analisis Tingkat Minat Belajar Mahasiswa Pendidikan Ekonomi dalam Perkuliahan Daring Masa Pandemi Covid 19. Edukatif: Jurnal Ilmu Pendidikan,3(4), 16381646.

Harandi, S R. (2015). Effect of e-learning on students' motivation. Procedia-social and behavioral science, 181(01). 423-430.

Nasrah, N., \& Muafiah, A. M. A. (2020). Analisis Motivasi Belajar Dan Hasil Belajar Daring Mahasiswa Pada Masa Pandemik Covid-19.JRPD OUrnal Riset Pendidikan Dasar), 3(2), 207-213.

Rosa, N. N. (2020). Hubungan Dukungan Sosial Terhadap Motivasi Belajar Daring Mahasiswa Pada Masa Pandemi Covid-19. TANJAK: Journal of Education and Teaching, 1(2), 147-153.

Sahu, P. (2020). Closure of Universities Due to Coronavirus Disease 2019 (COVID-19): Impact on Education and Mental Health of Students and Academic Staff. Cureus, 2019(April).

https://doi.org/10.7759/cureus.7541.

Sur, W. A. A., Hasanah, M., \& Mustofa, M. R. (2020). Analisis Motivasi Belajar Mahasiswa dengan Sistem 
Pembelajaran Daring Selama Masa Pandemi Covid19. Jurnal Equation: Teori dan Penelitian Pendidikan Matematika, 3(2), 157-171.

Surat Edaran Kemendikbud No. 4 Tahun 2020. Pelaksanaan KebijakanPendidikan dalam Masa Darurat Penyebaran Corona Viru Disease Covid 19. Diakses pada $\quad 30 \quad$ Mei 2020 dari https://pusdiklat.kemdikbud.go.id/suratedaranmendikbud-no-4-tahun-2020-tentangpelaksanaan-kebijakan-pendidikandalam-masadarurat-penyebaran-corona-virus-disease-covid-19/.

Uno, H. B. (2016). Teori motivasi dan pengukurannya analisis di bidang pendidikan. Jakarta: Bumi Aksara. 


\section{BAB II \\ PENINGKATAN KEMAMPUAN SUMBER DAYA}

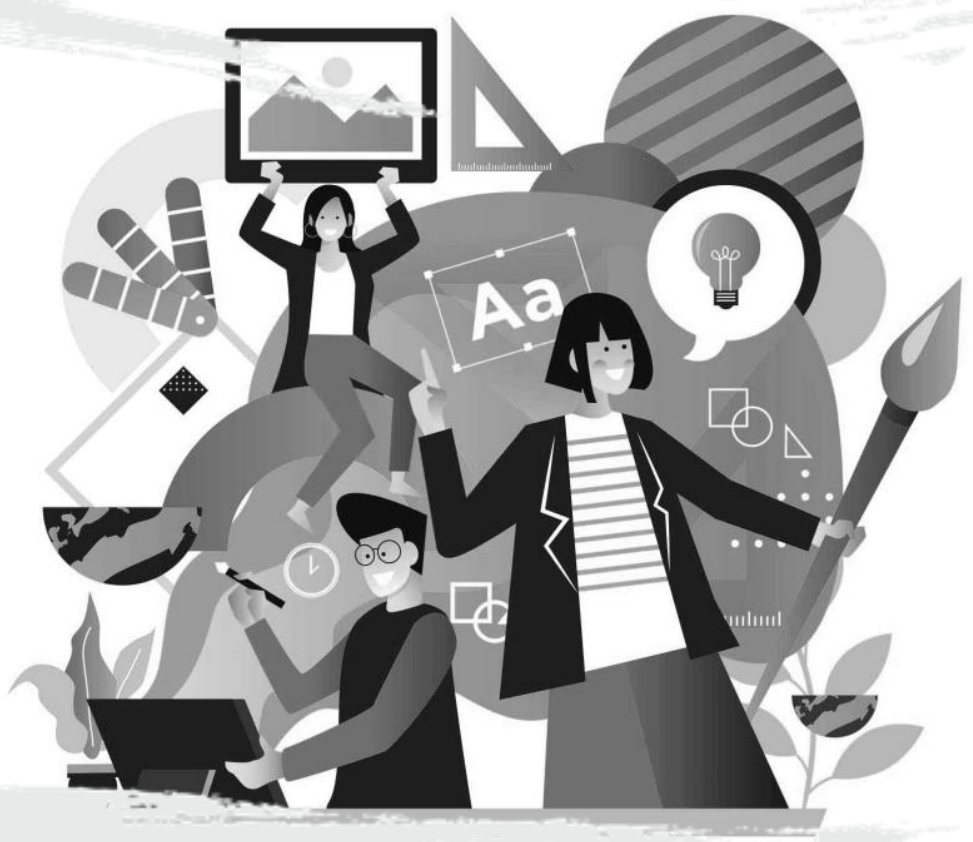




\title{
COVID-19 DI ERA DIGITAL SEBAGAI JEMBATAN MELONCAT MEWUJUDKAN KOMPETENSI
}

\author{
Prof. Dr. Jonni Siahaan.,M.Kes.,AIF0 ${ }^{10}$ \\ Universitas Cenderawasih Papua
}

\begin{abstract}
"Pemanfaatan perkembangan teknologi digital memudahkan manusia dalam mewujudkan serta meningkatkan kompetensi di masa covid-19"
\end{abstract}

$\mathrm{D}$ unia masih terus dihebohkan dengan bermutasinya virus covid-19 ke varian Delta dan ke varian Lamda. Mutasinya varian Corona ini mengajak setiap insan manusia terus patuh dan tidak boleh kendor mematuhi protokol kesehatan dan terus berupaya menjaga kesehatan dan kebugaran tubuh agar imunitas tubuh tetap tinggi. Pandemi covid-19 dalam waktu lama tentu secara perlahan mengubah peradapan manusia dalam bersikap dan berperilaku setiap hari. Covid secara sadar telah mengubah cara bersosial masyarakat seperti selalu jaga jarak saat sedang berdiri, duduk, berjalan, berlari/jogging, belajar, berlatih mengejar prestasi olahraga, mengikuti pelatihan,

10Penulis lahir di Martubung (Medan) 13 Nopember 1965. Penulis merupakan Guru Besar Ilmu Pendidikan Olahraga di Universitas Cenderawasih Papua. Saat ini menjabat sebagai Sekretaris Dewan Pakar Pengurus Pusat ISORI (Ikatan Sarjana Olahraga Indonesia) 2021-2025. Sebagai wakil ketua Sport Science di PB PRSI (2021-2025). Penulis menyelesaikan gelar sarjana Pendidikan Kepelatihan FPOK di IKIP Medan (1990). Program magister Gizi Masyarakat di Unair Surabaya, dan doktor di Pascasarna UNNES Semarang (2008). 
penataran, dan lain-lain, bukan berarti berjarak karena saling membenci tetapi untuk menjaga kesehatan bersama.

Hidup harmoni tetapi tetap jaga jarak dan patuh prokes ketika sedang berada dalam suatu kegiatan atau perjumpaan menjadi perilaku model baru sebagai oleh-oleh dari pandemi covid-19. Virus corona memang ada di sekitar hidup manusia. Olehkarenanya harus bijak mensikapinya, bagaimana caranya agar hidup tetap eksis. Pemerintah dan masyarakat dengan perannya masing-masing, saling mendukung mengatasi virus corona ini.

Pemerintah RI bersama gugus covid-19 nasional dan daerah berusaha mengatasi virus corona baik dengan cara mempercepat vaksin gratis bagi seluruh penduduk di Indonesia termasuk menerapkan regulasi PPKM (permberlakuan pembatasan kegiatan masyarakat) dengan berbagai level. Kerjasama yang baik, Pemerintah dan masyarakat akan mempercepat terbebasnya Indonesia dari virus corona. Hidup dalam kondisi normal dan bebas virus corona sangat dinanti-nantikan.

Kabar gembira secara nasional dan daerah terus menurun penderita virus corona di akhir bulan Agustus 2021. Kabar ini bukan berarti setiap insan boleh bebas sebebasnya lepas prokes dan boleh menjalani kehidupannya tanpa patuh pada Protokol kesehatan. Penulis menyarankan agar sikap dan perilaku yang baik untuk kesehatan harus terus dipertahankan, misalnya selalu pakai masker ketika berada di luar rumah, dalam transportasi umum, di pasar tradisional dan modren, di MalMal atau di tempat keramaian. Selain itu berusaha untuk makan bergizi, pikiran/psikis yang sehat, tubuh sehat dan bugar terus terjaga dengan rutin berolahraga baik pagi atau 
sore hari, 30-60 menit jogging dan/atau berjalan sebanyak 10.000 langkah setara $6 \mathrm{Km} /$ hari/3x seminggu.

Berolahraga secara teratur dengan durasi yang cukup membuat tubuh menjadi sehat dan bugar hingga memiliki tingkat kebugaran jasmani. Mensana incorpore sano ungkapan dalam Bahasa Latin yang artinya dalam tubuh yang sehat terdapat jiwa yang sehat/kuat. Tubuh yang sehat dan bugar wajib dimiliki seseorang agar dapat bekerja dalam waktu yang relatif lama tanpa harus mengalami kelelahan yang berarti. Kondisi fisik seperti ini diperlukan menghadapi virus corona.

Pandemi covid-19 mengingatkan setiap insan agar terus berupaya memiliki tubuh sehat, bugar dan menguasai digital dan memanfaatkannya untuk menguasai suatu kompetensi dan dengan jiwa yang kuat dapat menjalani hidup penuh rintangan akibat virus corona. Kondisi inilah disebut tangguh menghadapi pergumulan hidup dan tumbuh menjadi sumber daya manusia (SDM) tangguh. sebagaimana tema HUT RI ke-76 Tahun 2021 yakni "Indonesia Tangguh dan Indonesia Tumbuh".

Perang terhadap virus covid-19 harus terus dilakukan dengan memanfaatkan digital secara optimal. Kecanggihan digital di tengah covid harus dapat dijadikan sebagai peluang mewujudkan sesuatu yang baru. Digital akan memudahkan memiliki sesuatu yang baru karena sumber materi ajarnya mudah diakses baik melalui Laptop, Handphone dan lainnya, kapan dan dimanapun bisa yang penting ada jaringan internet. Media belajar seperti elearning, konten You Tube sebagai produk digital banyak digunakan manusia sebagai sumber belajar sehingga sangat mungkin seseorang memiliki suatu kompetensi yang berlevel tinggi. 
Pemerintah RI terus berupaya agar seluruh rakyat Indonesia dapat menjalani hidupnya secara normal. Segala daya upaya dilakukan seperti memberlakukan PPKM ber level 1-4, memberi vaksin gratis, menjaga harga sembako stabil dan lain-lain. Ada relasi yang kuat antara tingginya jumlah masyarakat yang sudah vaksin dengan berkurangnya jumlah penderita covid-19. Memang tidak ada yang bisa menjamin bahwa setelah mendapat vaksin tidak akan terkena covid-19 lagi, terbukti masih ada saja yang terkena virus corona, tetapi peluang sembuhnya lebih besar.

Hidup bersahabat dengan virus covid-19 sepertinya sudah tidak bisa terelakkan lagi. Roda kehidupan harus terus berjalan, digital terus semakin canggih sistem kerjanya, kompetensi manusia juga tentu harus semakin canggih. Kecanggihan digital ini tentu akan berpengaruh pada pekerjaan manusia yang sudah lama di tekuni secara profesional, sangat mungkin harus ditinggalkan karena sudah ada produk yang baru lebih murah, efisien dan praktis. Pemikiran inilah yang menginspirasi penulis menorehkan pemikiran, bagaimana setiap insan dapat bertahan hidup di tengah pandemi covid, dan bagaimana digitalisasi dapat mewujudkan impian yang tersaji serba cepat dan canggih. Kecepatan sistem kerja digital yang sangat canggih inilah yang melandasi penulis bahwa setiap insan di era digital sangat mungkin dapat melakukan percepatan peningkatan suatu kompetensi.

Virus covid-19 bersanding dengan digitalisasi ibarat dua sisi mata uang yang tidak dapat dipisahkan saat ini. Hal ini memberi arti bahwa setiap individu harus dapat bersahabat dengan virus corona dengan tetap patuh pada prokes covid-19, tetap menjaga tubuh agar tetap sehat dan 
bugar, mengkonsumsi makanan bergizi, istirahat yang cukup dan pikiran jangan stress meskipun dihadapkan pada berbagai permasalahan hidup. Dalam kondisi normal pun ada banyak masalah dalam hidup apalagi di tengah pandemi covid-19 dimana salah satu problema terbesarnya adalah kesulitan dalam ekonomi keluarga. Fakta ini menuntut suatu kompetensi agar mampu mengelola segala sumber daya yang ada, dan mengaturnya dengan baik setiap hari.

Manusia secara tidak langsung diminta untuk memiliki kompetensi yang mumpuni agar dapat bertahan hidup dan mindset bahwa virus corona harus dianggap sebagai penyakit virus biasa seperti flu/ pilek, batuk dan lain-lain. Sebagaimana Negara Singapore sudah mengubah mindsetnya bahwa covid-19 sudah dianggap seperti flu biasa, dan siap hidup berdampingan dengan virus corona. Singapore mempersiapkan rakyatnya untuk menghadapi covid-19 sebagai partner dalam hidup sehari-hari. Dengan demikian rakyatnya dapat bekerja normal, berpergian dan berbelanja tanpa karantina. Bagaimana dengan Indonesia, diperlukan suatu kajian yang kuat dan mendasar, karena kharakter sosial budaya rakyat Indonesia tidak sama dengan Singapore.

Pandemi covid-19 harus diatasi secara bersama-sama dengan kharakter budaya Indonesia selain wajib ikut vaksin gratis dari Pemerintah RI, walaupun ada larangan berkumpul bukan berarti tidak boleh beraktivitas, tetapi sebaliknya aktivitas fisik tetap dilaksanakan secara teratur agar tubuh tetap terjaga sehat dan bugar seperti jalan, jogging, lari di area terbuka luas yang udaranya sejuk, atau berolahraga di rumah yang posisinya terbuka dengan kondisi luar agar dapat menghirup udara bebas yang segar agar imunitas tubuh tetap terjaga tinggi. 
Aktivitas fisik bersifat perorangan atau kelompok kecil wajib boleh dilakukan agar jasmani tetap bugar dan sehat. Kondisi tubuh seperti ini justru sangat baik sebagai penangkal masuknya virus corona. Selain aktivitas fisik yang berkaitan dengan olah gerak, juga dilakukan berbagai kegiatan yang mengarah pada penguasaan suatu keterampilan (skill), agar berbagai keahlian dapat dipelajari secara mandiri dengan mudah.

Digital terbukti membuat sumber belajar menjadi tidak terbatas, sehingga membuat seseorang dapat menguasai suatu kompetensi, syaratnya adalah motivasi yang tinggi untuk mau belajar setiap waktu. Apabila seseorang memiliki suatu kompetensi dapat dipastikan akan mampu mandiri dalam bekerja untuk dirinya dan berharap akan mampu menciptakan lapangan pekerjaan untuk orang lain. Menguasai kompetensi hingga mumpuni di era digital relatif menjadi mudah karena mudahnya mendapatkan sumber ilmu pengetahuan, keterampilan dan kharakter sebagai domain menciptakan suatu kompetensi.

Secara estimologi kompetensi diartikan sebagai suatu kemampuan dan/atau keterampilan (skill) yang dimiliki seseorang meliputi aspek pengetahuan, keterampilan, dan sikap (perilaku). Aspek ini tentu sangat berguna bagi kehidupan. Kemudian Undang-Undang Republik Indonesia Nomor 20 Tahun 2003 Tentang Sistem Pendidikan Nasional Pasal 35 (ayat1) menyatakan bahwa kompetensi mencakup sikap, pengetahuan dan keterampilan sesuai standar. Undang-Undang RI Nomor 3 Tahun 2005 Tentang Sistem Keolahragaan Nasional menyatakan bahwa kompetensi adalah kemampuan minimal yang dimiliki tenaga keolahragaan yang mencakup sikap, pengetahuan dan keterampilan dalam bidang keolahragaan. 
Berdasarkan penjelasan diatas dapat disimpulkan bahwa kompetensi adalah kemampuan minimal yang dimiliki seseorang mencakup domain pengetahuan, keterampilan dan sikap. Ketiga domain inilah yang menjadi indikator utama untuk mengukur sejauhmana seseorang menguasai kompetensinya. Domain ini dapat dikuasai baik secara mandiri maupun dalam suatu komunitas misalnya mengikuti pelatihan, penataran, workshop, seminar, webinar, materi ajar berupa media e-learning dan konten You Tube, dan media sosial lainnya. Artinya digital akan memampukan seseorang sampai pada standar kompetensi.

Apabila standar kompetensi dicontohkan dalam bidang keolahragaan sebagaimana diungkapkan dalam UU RI No.3/2005 Tentang Sistem Keolahragaan Nasional (SKN) bahwa kompetensi adalah kemampuan minimal mencakup pengetahuan, sikap dan keterampilan. Yang diperoleh melalui pendidikan, kelayakan fisik dan psikis, penataran/pelatihan. Kompetensi harus diuji kebenarannya untuk mengukur sejauhmana kemampuan minimal seseorang sesuai dengan persyaratannya.

Perkembangan Industri 4.0 di era digital menuntut tercapainya standar kompetensi yang ditandai dengan pemberian sertifikat kompetensi yang merupakan pengakuan terhadap keahlian yang dimiliki dalam melakukan suatu pekerjaan. Untuk memperoleh sertifikatnya sangat tidak mudah olehkarena ada sejumlah persyaratan yang harus dipenuhi. Olehsebab itu kemajuan digital dapat mempercepat seseorang memenuhi persyaratan tersebut. Belajar dan berlatih secara mandiri dipandu materi ajar produk digital seperti media e-learning, konten You Tube dapat membuat seseorang menjadi lebih cepat mencapai keahliannya. 
Fakta inilah yang mendasari pemikiran penulis bahwa digital yang sistem kerjanya canggih dapat dijadikan sebagai jembatan meloncat untuk mewujudkan suatu kompetensi yang berjenjang tentunya menuju jenjang yang sangat tinggi. Semakin tinggi tingkat kompetensi seseorang maka semakin mahal harganya seseorang dalam dunia kerja. Olehkarena itu tidak selamanya musibah seperti pandemi covid-19 menghancurkan kehidupan manusia. Justru eksistensi manusia berubah semakin canggih dan muncul hal-hal baru diluar dugaan dan nalar berpikir manusia secara normal.

Kemajuan digital harus disikapi sebagai peluang untuk mengembangkan kompetensi menjadi lebih bermanfaat bagi diri sendiri, keluarga, masyarakat dan negara. Kontribusi sebagai generasi milineal menjadi nyata dalam mengisi Kemerdekaan RI ke-76 Tahun 2021. Generasi milineal harus cepat tanggap melihat kemajuan digital. Bila tidak maka cepat/lambat akan terlindas dengan kemajuan zaman. Revolusi industri 4.0 terus berpacu menjadi 5.0 dan seterusnya, maka sangat tidak heran jika suatu saat tenaga kerja manusia akan digantikan dengan robot yang dikendalikan digital. Jika sudah demikian, manusia tanpa memiliki kompetensi tidak akan mudah mendapat tempat yang layak untuk bekerja di dunia ini. 


\title{
MEMBANGUN SUMBER DAYA MANUSIA \\ (SDM) UNGGUL DENGAN \\ PENGEMBANGAN PENDIDIKAN \\ DI TENGAH PANDEMI COVID-19
}

\author{
Dr. Syarifuddin, S.Pd., M.Pd 11 \\ Universitas Sriwijaya
}

"Meningkatkan akses mutu pendidikan yang tinggi guna menciptakan sumber daya manusia yang unggul, kreatif, dan inovatif harus dilakukan terobosan perubahan sistem yang relevan dengan situasi di tengah pandemi covid 19"

Corona Virus Disease 2019 (Covid-19) merupakan
penyakit menular yang disebabkan oleh SARS Cov-2. Penyakit ini pertama kali dilaporkan di Wuhan, Provinsi Hubei, Cina. Covid-19 telah menginfeksi lebih dari empat juta orang diseluruh dunia (Wikipedia, 2021). Sejalan dengan kondisi tersebut, WHO telah menetapkan Covid-19 sebagai pandemic global, sehingga secara resmi WHO menetapkan dua pandemic global sekaligus yaitu HIV/AIDS dan Covid-19. Pandemic Covid-19 memberikan dampak yang signifikan terhadap lapisan masyarakat, salah satunya dalam bidang pendidikan. Pada masa pandemic Covid-19

11Penulis lahir di Lahat 30 November 1984, penulis merupakan Dosen Universitas Sriwijaya dalam bidang Teknologi Pendidikan, penulis menyelesaikan gelar Sarjana Pendidikan Sejarah di Universitas Sriwijaya (2006), gelar Magister Teknologi Pendidikan di Universitas Sriwijaya (2010), dan akhirnya Doktor Teknologi Pendidikan diselesaikan di Universitas Negeri Jakarta (2018). 
sangat memerlukan planning yang berbeda dan efektif, melalui pendidikan diharapkan dapat membentuk sumber daya manusia unggul yang berkualitas dan berintegritas. Melalui sumber daya manusia yang berkualitas dan berintegritas baik secara fisik maupun mental akan memberikan dampak positif dalam pembangunan nasional.

Sumber daya manusia yang berkualitas dan berintegritas dapat tercapai dengan memperhatikan beberapa faktor, salah satunya yaitu melalui pendidikan. Melalui pendidikan, maka diperlukan penataan terhadap sistem pendidikan menyeluruh dengan mengedepankan asas relevansi pendidikan terhadap kebutuhan masyarakat dan dunia kerja. Sesuai dengan pernyataan dari Jenderal Kemenristekdikti Ainun Na'im dalam diskusi media forum merdeka barat (FMB) 9 bertajuk membangun sumber daya manusia menyosong Era Industri 4.0: memastikan infrastruktur teknologi informasi dan komunikasi, industry manufaktur, SDM Riset, dan skema dukungan anggaran, mengatakan bahwa "demi membangun sumber daya manusia Indonesia unggul, kreatif, dan inovatif dalam menyosong era revolusi industry 4.0, kementrian riset, teknologi, dan pendidikan tinggi senantiasa meningkatkan akses mutu pendidikan tinggi bagi putra-putri Indonesia. Pendidikan jarak jauh dan pembelajaran secara daring $(e-$ learning) merupakan terobosan baru kemenristeksikti dalam meningkatkan akses pendidikan tinggi yang bermutu ke seluruh wilayah Indonesia (News Akurat, 2019)." Sehingga dapat dianalisis bahwa pembangunan infrastruktur teknologi dan komunikasi menjadi peran vital dalam mengupayakan pembangunan SDM Indonesia yang unggul dan mampu bersaing ditingkat global dalam era revolusi industry 4.0. 
Pembangunan sumber daya manusia yang berkualitas dan berintegritas dapat dibangun melalui pengembangan pendidikan yang sesuai dengan kurikulum 2013, salah satu tujuan kurikulum 2013 yakni mengembangkan pendidikan dapat dilakukan dengan menanamkan nilai karakter bangsa yang berlandaskan pada nilai-nilai Pancasila. Pengembangan karakter individu seseorang hanya dapat dilakukan didalam lingkungan sosial dan budaya yang bersangkutan. Hal ini menjelaskan bahwa pengembangan karakter bangsa dapat dilakukan dalam suatu proses pendidikan yang tidak melepaskan peserta didik dari lingkungan sosial, budaya masyarakat, dan budaya bangsa. Sekolah sebagai Tripusat pendidikan ikut berperan penting dalam mengembangkan segala potensi yang dimiliki peserta didik. Pengembangan potensi peserta didik dapat dilakukan melalui media atau sumber belajar dalam proses pembelajaran. Proses pembelajaran ini dapat membantu peserta didik dalam membangun perilaku sosial yang saling menghargai dan menghormati perbedaan yang ada, hal ini dapat dibangun melalui pendidikan pembelajaran sejarah.

Pembelajaran sejarah menurut Susanto (2014:62) adalah kegiatan membangun perilaku sosial, perilaku sosial ini dapat berupa saling menghargai adanya perbedaan dan saling menghormati agar dapat hidup berdampingan pada suasana multikulturalisme. Pernyataan tersebut juga didukung oleh teori menurut Ali dalam Hidayat (2017:95) bahwa pembelajaran sejarah adalah pembelajaran yang terjadi dan fokus pada peserta didik dalam belajar dan memahami materi sejarah untuk membangkitkan semangat nasionalisme, kebangsaan, dan cinta tanah air peserta didik. Peristiwa sejarah yang terjadi dimasa lampau memiliki nilai kearifan yang dapat dijadikan sebagai ilmu pengetahuan 
dalam meningkatkan kecerdasan dan membentuk karakter peserta didik. Pembelajaran sejarah dengan memanfaatkan media dan sumber belajar sejarah adalah cara yang paling efektif bagi pendidik untuk memperkenalkan peristiwa sejarah kepada peserta didik.

Belajar dengam memanfaatkan media dan sumber belajar sangat berguna bagi pendidik untuk memperkenalkan peristiwa sejarah dalam proses pembelajaran, dan memudahkan peserta didik untuk memahami pelajaran sejarah. Pemanfaatan media dan sumber belajar dalam kegiatan pembelajaran sejarah telah mengalami perubahan yang cukup signifikan. Hal tersebut dapat dilihat perubahanannya saat ini. Pada saat sebelum pandemic Covid-19 menyerang bangsa Indonesia, pendidik dan peserta didik secara bebas memanfaatkan media dan sumber belajar. Namun saat ini, dengan adanya pandemic Covid-19 segala aktivitas pembelajaran harus mengalami keterbatasan dan perubahan. Seperti, pendidik dan peserta didik sudah jarang berkunjung secara langsung dalam memanfaatkan perpustakaan, museum, dan situs bersejarah, melainkan semuanya sudah tersedia secara Online di Internet. Keterbatasan tersebut disebabkan adanya Darurat Kesehatan Nasional akibat Pandemic Covid 19 , yang membuat pendidik dan peserta didik melakukan proses pembelajaran sejarah dilakukan dari rumah (Daring) atas kebijakan pemerintah.

\section{Daftar Pustaka}

Akurat news. https://akuratnews.com/wujudkan pendidikan dan kesehatan untuk sdm berkualitas. Diakses pada 22 Agustus 2021. Pukul 12.38 WIB. 
Hidayat, B. 2017. Pengenalan Ruang Sejarah (History Room) Sebagai Media Pembelajaran Sejarah Bagi Pendidik di Kota Metro. Jurnal HISTORIA Vol.5 No.1 Tahun 2017.

Susanto, H. 2014. Seputar Pembelajaran Sejarah, Isu Gagasan, dan Strategi Pembelajaran. Yogyakarta: Aswaja Pressindo.

Wikipedia.com https://www.google.com/ jumlah korban pandemi covid 19 diseluruh dunia. Diakses pada 22 Agustus 2021. Pukul 10.15 WIB. 


\title{
OPTIMISME DAN PESIMISME MEMBANGUN SDM UNGGUL DI KONDISI PANDEMI COVID-19
}

\author{
Dr. Rif'iy Qomarrullah.,S.Pd.,M.Or ${ }^{12}$ \\ Universitas Cenderawasih Papua
}

"Manusia memiliki dua pemikiran yang saling berseberangan, dimana salah satu diantaranya yang lebih dominan akan mempengaruhi pembentukan sumber dayanya"

$\mathrm{M}$ embangun sumber daya manusia yang unggul adalah menjadi kaharusan bagi setiap bangsa di era perkembangan revolusi Industri 4.0 dimana teknologi digital sangat berperan dalam membangun peradapan baru dengan dunia kerja yang baru, berbeda dengan sebelumnya. Artinya segala pekerjaan yang sudah dikuasai secara profesional, bisa saja ditinggalkan karena sudah ada yang baru lebih praktis, murah meriah, mudah diakses dan berdaya guna tinggi bagi kelangsungan hidup manusia.

Kemajuan sistem kerja digital yang sangat canggih secara sadar memaksa manusia harus mampu beradaftasi jika tidak mau tertinggal bahkan terlindas. Teknologi digital

12Penulis Dr. Rif'iy Qomarullah.,S.Pd.,M.Or. Lahir di Jepara 1 Januari 1986. Penulis merupakan dosen di Universitas Cendrawasih Papua. Penulis menyelessaikan gelar sarjana Pendidikan Jasmani Kesehatan dan Rekreasi di Universitas Negeri Surabaya/Unesa (2011). Gelar magister Ilmu Keolahragaan/IKOR di Universitas Negeri Semarang/UNNES (2013). Dan gelar doktor Pendidikan Olahraga di Universitas Negeri Semarang/UNNES (2020). 
sudah merambat keseluruh profesi manusia dan bahkan mampu menggantikan sebagian pekerjaan manusia. Artinya kesempatan kerja manusia semakin berkurang karena sudah digantikan dengan teknologi digital, seperti memanfaatkan robotik yang dikendalikan digital mengerjakan pekerjaan profesioanl yang sudah lama ditekuni manusia.

Era digital ini tidak boleh dianggap sesuatu yang biasa saja atau permasalahan sosial yang biasa. Kesiapan sumber daya manusia (SDM) agar bisa bersanding dengan canggihnya sistem kerja digital yang canggih, sudah harus disikapi dengan mempersiapkan diri dengan keahliannya yang teruji atau tersertifikasi kompetensinya. Hal inilah yang mendasari Pemerintah RI bersama Kementerian Pendidikan Kebudayaan Riset dan Teknologi mewajibkan institusi Pendidikan tinggi di Indonesia mendisain kurikulum bermitra dengan dunia kerja sehingga setiap alumni perguruan tinggi wajib memiliki surat keterangan pendamping ijazah (SKPI) sebagai bukti bahwa alumni telah menjadi SDM handal atau unggul, siap kerja dan siap berkompetisi dalam era digitalisasi.

Untuk mendapatkan SDM unggul tentulah tidak mudah meskipun dengan bantuan digital dapat mempercepat terciptanya suatu kompetensi yang teruji keahliannya dan layak dikategorikan sebagai SDM unggul. Fakta di masyarakat bahwa digital membuat proses belajar anak didik di sekolah bahkan mahasiswa di perguruan tinggi terganggu untuk mewujudkan target belajar yang tinggi sesuai dengan tuntutan kurikulum. Tentu kondisi seperti ini berbanding terbalik, apabila dengan bantuan digital sangat diharapkan tercipta SDM unggul. Kondisi inilah yang mendasari pemikiran penulis bahwa saat ini muncul 
pandangan manusia bahwa telah bercampur aduk antara optimis dan pesimis dalam membangun SDM unggul di kondisi pandemi covid-19 dimana digital mendominasi semua pekerjaan.

Pandemi covid-19 dianggap sebagai penghalang (barrier) untuk mewujudkan SDM unggul meskipun digital telah menembus pikiran manusia tanpa batas dan sumber belajar yang sangat variatif untuk meningkatkan pengetahuan, keterampilan dan sikap (perilaku/kharakter) dengan mudah diperoleh dengan mengaksesnya di Handphone dan/atau Laptop, kapan dan dimana saja dapat digunakan untuk belajar dan berlatih materi ajar/latihan guna mengejar suatu keterampilan atau kompetensi yang diinginkan. Apabila materi tersebut dipelajari berulangulang dalam waktu yang relatif lama, maka sangat mungkin seseorang dapat dengan cepat memilki kompetensi.

Memiliki kompetensi yang tinggi selain ijazah dari lembaga pendidikan formal, layak disebut sebagai SDM unggul. Penguasaan materi yang teruji melalui suatu instrumen yang valid dan akuntabel secara independen sebagai syarat untuk mengukur kompetensi seseorang sebagai indikator SDM unggul. Untuk layak seseorang disebut unggul tentu selain memiliki pengetahuan, keterampilan dan kharakter yang terkait bidang yang ditekuni, dapat membuktikannya dalam dunia kerja yang sesungguhnya bukan simulasi.

Secara harfiah kompetensi diartikan sebagai kemampuan untuk melaksanakan pekerjaan yang dilandasi oleh pengetahuan, keterampilan dan sikap. Sinonim kompetensi yaitu keterampilan, kapabilitas, kapasitas, keahlian, ilmu pengetahuan dan lain-lain. Kompetensi seseorang yang tinggi eratkaitannya dengan tingkatan 
berpikirnya. Taxonomi Bloom mengemukakan bahwa tingkatan berpikir manusia adalah pengetahuan (knowledge), pemahaman (comprehension), penerapan (application), penguraian (analysis), sistesis (synthesis) dan evaluasi (evaluation).

Taxonomi Bloom versi Kreathwohl pada ranah kognitif terdiri dari 6 level yaitu; mengingat (remembering), memahami (understanding), menerapkan (applying), mengurai (analysis), menilai (evaluating) dan mencipta (creating). Level kognitif dan tingkatan berpikir seseorang dapat dijadikan sebagai dasar untuk mengukur tingkat penguasaan suatu keterampilan, yang selanjutnya dapat digunakan sebagai indikator memiliki suatu kompetensi. Sedangkan ranah afektif meliputi perilaku/sikap mendasarinya pada aspek perasaan dan emosi, seperti motivasi/minat, apresiasi, cara beradaftasi (penyesuaian diri). Sedangkan ranah psikomotor meliputi perilaku yang fokus atau menekankan pada aspek keterampilan motorik.

Prinsipnya penguasaan ranah pengetahuan, sikap dan keterampilan sampai pada level yang tinggi dan link dengan kebutuhan dunia kerja yang sesungguhnya, dapat dijadikan sebagai syarat menjadi SDM unggul. Untuk mewujudkan ketiga ranah tersebut di tengah kondisi pandemi covid-19 tentu menjadi pertanyaan besar, olehkarena tidak semua elemen pada ketiga ranah tersebut dapat dikuasai dengan digital. Inilah yang muncul dalam pemikiran banyak orang sehingga muncul pikiran optimis dan pesimis. Mungkinkah selama era pandemi covid-19 dapat menciptakan sumber daya manusia unggul dalam berbagai bidang. Pemikiran optimis dan pesimis sangat wajar terdapat dalam intuisi para generasi milineal. 
Optimisme dapat diartikan sebagai sebuah ungkapan pikiran yang sehat dan sangat baik untuk bangkit dari ketertinggalan atau dari ketidakmungkinan. Optimis merupakan sikap berpikir positif yang ditunjukkan seseorang ketika sedang menghadapi berbagai problema kehidupan. Hidup manusia berdampingan dengan masalah, rintangan dan tantangan. Olehkarena itu memiliki sikap optimis harus terus dipupuk. Jika tidak demikian maka sikap optimis hilang dan digantikan dengan sikap pesimis. Hidup harus selalu optimis agar dapat menjalani kehidupan dengan pikiran yang sehat dan secara optimal dapat menggunakan potensi yang dimilikinya.

Memiliki pemikiran yang selalu optimis sesungguhnya menjadi bekal mental (psikis) yang kuat untuk memperoleh tubuh sehat dan bugar. Memiliki kebugaran jasmani yang tinggi dapat menjadi bekal yang kuat untuk mendorong seseorang belajar sungguh-sungguh akan sesuatu hal yang menjadi kompetensinya. Kondisi ini sebagai bekal untuk mewujudkan keberhasilan masa depan. Pikiran optimis yang kuat, akan mampu membentuk motivasi instrinsik untuk fokus pada pekerjaan yang sudah ditekuni cukup lama bahkna mungkin sudah bertahun-tahun. Dalam konteks ini tentu peluang menjadi SDM unggul sangat besar.

Pemikiran pesimis sebaliknya dapat menghancurkan segala sesuatu yang sedang atau yang sudah dikerjakan. Pesimisme secara harfiah diartikan sebagai paham segala sesuatu. Kata pesimis berasal dari bahasa latin yang disebut pessimus yang artinya adalah buruk. Berpikir pesimis akan melihat hidup selalu berisi dengan kejahatan, meskipun faktanya selalu ada kebaikan dan kejahatan yang bercampur aduk dalam hati dan pikirannya. Setiap insan yang bersikap 
tidak mempunyai harapan (pesimis) akan muncul rasa kuatir, rugi, celaka bahkan mudah putus harapan.

Setiap manusia selalu saja memiliki dua sisi yang berbeda seperti pikiran yang optimis dan pesimis dalam mensikapi setiap fakta atau fenomena yang ada disekitarnya. Dalam kondisi ini mana yang dominan dalam hati dan pikirannya. Bila pikiran optimis lebih dominan dibandingkan pesimis maka segala yang direncanakan besar kemungkinan dapat diwujudkan. Sebaliknya bila pikiran pesimis lebih dominan maka segala rencana bias saja dibubarkan, atau ditinggalkannya dan cenderung menjadi seseorang yang tidak memiliki pengharapan di dunia.

Pandemi covid-19 ada disekitar hidup manusia saat ini. Vaksin sebagai salah satu upaya agar memiliki kekebalan tubuh atau imunitas yang tinggi menghadapi virus corona tersebut. Dalam konteks ini ada saja masyarakat yang berpikir pesimis akan mujarabnya vaksin menangkal virus corona, tetapi ada juga yang optimis bahwa vaksin membuatnya lebih percaya diri dan berani menjalankan roda kehidupannya setiap hari. Bagi masyarakat yang pesimis, penulis menyakini masih banyak yang tidak mau vaksin dan pesimis yang berlebihan membuatnya vaksin tidak terlalu perlu untuk diperoleh, cukup dengan mematuhi prokes covid-19 dengan baik tanpa kendor.

Virus Covid-19 masih ada di muka bumi ini, termasuk di Indonesia, dan kehidupan harus berjalan sebagaimana mestinya. Olehkarena itu pikiran pesimis harus lebih dominan dalam hati dan pikiran manusia terlebih lagi dalam membangun sumber daya manusia unggul. Secara umum masyarakat masih pesmis atau ragu pikirannya apakah mungkin hanya dengan bantuan digital dapat meningkatkan kualitas atau keterampilannya. Selama ini diketahui bahwa 
proses belajar tatap muka saja masih sulit untuk memperoleh SDM unggul, apalagi di era pandemi dimana tatap muka dilarang untuk sementara waktu guna mencegah penyebaran virus corona.

Salah satu wujud penampilan yang dapat dijadikan sebagai parameter SDM unggul adalah kemampuan unjuk kerja (action) secara mandiri. Pengetahuan yang dimiliki sebagai penunjang. Memang disadari bahwa suatu keahlian tidak akan optimal dikuasai apabila tidak memiliki cukup pengetahuan.. Misalnya untuk menguasai suatu keterampilan/keahlian setidaknya ada tiga tahap yang harus dilalui yaitu tahap kognitif yaitu menguasai keterampilan motorik secara teori, dimana kisi-kisi yang menjadi indikatornya dapat diketahui secara benar. Pengetahuannya tentang gerak yang akan ditampilkan relatif cukup.

Selanjutnya tahap psikomotor yaitu mampu mempraktekkan pengetahuannya secara teori dalam wujud penampilan gerak yang tentunya dilaksanakan secara bertahap dimulai dari gerak yang mudah berlanjut ke yang relatif sulit. Pengulangan akan keterampilan yang sudah dipelajari harus terus dilakukan hingga benar-benar sesuai dengan teorinya. Setelah sampai tahap ini, maka seterusnya adalah tahap otomatisasi, dimana keterampilan geraknya sudah sampai pada tingkat mahir. Untuk sampai pada tahap mahir dibutuhkan repetisi berkali-kali hingga keterampilan gerak tersebut secara reflex sudah dapat ditampilkan.

Pandemi covid-19 yang bersamaan dengan kemajuan teknologi digital dapat mewujudkan SDM unggul, oleh karena segala pengetahuan, keterampilan dan kharakter gerak dapat dipelajari dari media e-learning atau konten You Tube, merupakan produk digital. Masalahnya 
dibutuhkan kesabaran yang tinggi olehkarena yang mengerjakan diri sendiri termasuk yang memberi feedback pada setiap proses belajar atau latihan yang terjadi. Hal inilah yang mendasari pemikiran penulis bahwa sekalipun pandemi covid-19 tetapi dengan adanya kemajuan digitalisasi, keinginan untuk mencetak SDM unggul masih sangat mungkin akan terwujud.

Mencetak Sumber daya manusia unggul di Indonesia menjadi keharusan guna menghadapi persaingan ketat yang tidak terlihat lawan tandingnya. Pikiran disrupsi di era digital menuntut tersedianya SDM unggul pada semua bidang pekerjaan. Oleh sebab itu gunakanlah kemajuan digital ini untuk mempercepat terbangunnya SDM unggul. Generasi milineal yang unggul lah yang dapat menciptakan lapangan pekerjaan bukan semata-mata sebagai pencari kerja. Jangan tanyakan apa yang diberikan negara padamu tetapi tanyakan apa yang generasi milinel berikan kepada negara dan bangsa untuk kemajuan Indonesia dan persiapan menuju Indonesia emas tahun 2045. 


\title{
ADAPTASI PEMBELAJARAN TERHADAP BERGESERNYA KELAS OFFLINE KE ONLINE DI MASA PANDEMI COVID-19
}

\author{
Dr. Abdul Malik Iskandar, S.Ag, M.Si ${ }^{13}$ \\ Universitas Megarezky
}

\begin{abstract}
"Peralihan model pembelajaran offline ke dalam online di masa pandemi memerlukan penyesuaian bagi stakeholder pendidikan, apakah inovasi ini sudah teruji efektif? semoga wabah covid-19 segera berlalu"
\end{abstract}

\section{Pendahuluan}

Wantaman pandemi Covid-19 di jagad semesta ini telah merubah segalanya. Tatanan sosial kehidupan manusia seolah tunduk pada hukum yang ditetapkan oleh sang raja, Covid-19. Itulah realitas sosial hari ini, walaupun Covid-19 telah berulang tahun yang ke-1, khususnya di Indonesia kondisinya belum terprediksi kapan berakhirnya. Kasus positif harian nasional masih menyentuh angka fantastis, puluhan ribu. Dan belum terkendali, kebiajakan-kebijakan pemerintah dalam pembatasan kegiatan sosial masyarakat belum memperlihatkan angka-angka signifikaan perubahan

\footnotetext{
13Dr. Abdul Malik Iskandar, S.Ag, M.Si, lahir di Kampiri, Desa Cipta, 14 Oktober 1969 , penulis merupakan Dosen Universitas Megarezky (UNIMERZ) dan dosen Luar Biasa Universitas Alauddin Makassar UINAM Makassar . Penulis menyelesaikan gelar sarjana Tadris Pendidikan Bahasa Inggris di UIN Alauddin Makassar (1996), gelar Magister Ilmu Komunikasi di UNHAS (2009), gelar Doktor Sosiologi di UNM ( 2015), dan Beasiswa Sandwich like (short course) dikti (2012) di Northern Illinois University-Dekalb City-USA.
} 
penurunan jumlah kasus positif, dan kematian. Covid-19 menjelma menjadi sosok yang sangat menakutkan penghuni bumi ini, khususnya manusia.

Ada sebab ada akibat. Covid - 19 telah menciptkan dampak sangat luas dan masif ke berbagai bidang kehidupan. Selain di bidang kesehatan sebagai keadaan yang paling utama, dampak-dampak yang paling dahsyat antara lain pada sektor transportasi, ekonomi, politik, sosial budaya, keagamaan, tak terkecuali bidang pendidikan. Covid-19 muncul sebagai sebuah keadaan yang super tibatiba yang melahirkan perubahan sosial . Oleh Soemardjan mendefiniskan perubahan sosial adalah segala perubahan padA lembaga kemasyarakatan di dalam masyarakat , yang memengaruhi sistem sosialnya, termasuk di dalamnya nilai-nilai, sikap-sikap, dan pola perilaku di antara kelompok dalam masyarakat (Setiadi \& Kolip, 2011 : 610). Dan dari perubahan inilah diperlukan adaptasi atau penyesesuian diri maupun kelompok dan lembaga.

Dampak di bidang pendidikan, pemerintah pusat melalui Kemendikbud mengeluarkan keputusan meniadakan seluruh pembelajaran tatap muka langsung atau luar jaringan diganti dengan pembelajaran daring atau dalam jaringan atau popular pembelajaran on line yang sudah berlangsung dua tahun . Pada pemerintah wilayah dan kabupaten/kota masing-masing mengeluarkan panduan penyelenggaraan pendidikan dan pembelajaran pada jenjang dan satuan pendidikan untuk mengawasi kebijakan dari pusat. Mulai dari SD sampai pada Perguruan Tinggi.

Adaptasi dalam pembelajaran sebuah keniscayaan bahkan tanpa ada sekalipun kondisi yang memaksa seperti bencana alam dan bencana sosial kemanusiaan adaptasi 
tetap diperlukan untuk menghindari pada titik kejenuhan. Ketidaksiapan menghadapi kondisi-kondisi darurat dapat mengakibatkan dalam pembelajaran akan memunculkan emosi-emosi negatif oleh peserta didik dan guru . Emosi negatif tersebut diakibatkan oleh banyak faktor, misalnya faktor kelelahan, hal baru, kesulitan belajar, fasiltas belajar tak medukung, jaringan tak cukup. Kondisi negatif seperti ini harus dapat dilaksanakan penyesuaian diri.

\section{Adaptasi Proses Pembelajaran}

Tak mungkin pelaut dapat menghindari ombak. Pelau hanya bisa beradaptasi dengan ombak. Manusia berada dalam kondisi seperti ini, kita sedang berada dalam posisi ambivalen, berada di antara dua arah yang bertentangan, yaitu ingin tetap aktif kerja tetapi takut sakit, covid terus mengintai. Laksana benci tapi rindu, diperlukan adaptasi atau penyesuaian diri.

Adaptasi diartikan sebagai sebuah penyesuaian diri dengan kebutuhan atau tuntutan baru. Atau dapat pula berarti usaha mencari keseimbangan untuk kembali ke suatu keadaan normal. Adaptasi sebagai proses sosial yang di dalamnya ada orang dan golongan atau lembaga kebudayaan mengalami perubahan-perubahan, sehingga mereka menyesuaikan dengan keadaan sekitarnya (yang tadinya asing), lambat laun menjadi bagian yang menyatu dengan masyarakat tersebut, ( Iskandar, A Malik 2021: 7). Adaptasi adalah proses yang menyebabkan organisme memperoleh kecocokan yang menguntungkan dengan lingkungan yang ada, dan hasil dan proses tersebut adalah karakteristik organisme yang menyebabkan cocok dengan perangkat kondisi tertentu tempat organisme-organisme itu biasanya berbeda. Selain itu, adaptasi juga dapat diartikan sebagai proses mengatasi halangan-halangan dari 
lingkungan , memanfaatkan sumber-sumber terbatas untuk kepentingan lingkungan dan sistem, penyesuaian dari kelompok maupun pribadi terhadap lingkungan dan proses untuk menyesuaikan dengan situasi yang berubah (Soekanto, 1990).

Sanderson (1995) mendefinisikan adaptasi sebagai sifat sosial yang muncul akibat adanya kebutuhan tujuan, dan hasrat para individu. Hal ini menggerakan manusia untuk menciptakan teknologi dan cara-cara yang digunakan untuk menyerap sumber daya alam yang dibutuhkannya (leo \& Ika, 2002). Adapatasi sosial diperlukan karena terjadinya perubahan sosial pula. Oleh Soemarjan mendefinisikan perubahan sosial sebagai perubahan pada lembaga-lembaga kemasyarakatan di dalam suatu masyarakat, yang memengaruhi sistem sosialnya , termasuk di dalamnya nila-nilai, sikap-sikap , dan pola-pola perilaku di antara kelompok-kelompok dalam masyarakat (Setiadi \& Kolip, 2011 : 610)

Selanjutnya, apa itu pembelajaran ? pembelajaran secara umum didefinisikan adalah proses interaksi peserta didik dengan pendidik dan sumber belajar pada suatu lingkunagan belajar. Gagne (1977) pembelajaran adalah seperangkat peristiwa-peristiwa eksternal yang dirancang untuk mendukung proses internal. Lebih lanjut Gagne mengatakan bahwa teorinya akan lebih lengkap dengan mengatakan bahwa pembelajaran dimaksudkan untuk menghasilkan hasil belajar, situasi eksternal harus dirancang sedemikian rupa untuk mengaktifkan, mendukung, dan mempertahankan proses internal untuk mendukung peristiwa-peristiwa belajar.

Adapatasi pembelajaran adalah sebuah proses belajar mengajar yang disesuaikan dengan situasi sosial yang 
sedang terjadi dalam lingkungan pendidikan yang sebabkan oleh keadaan tertentu yang bersifat memaksa seperti terjadinya bencana alam, konflik sosial, peperangan, wabah penyakit menular yang berkepanjangan. Realitas sosial yang sedang dihadapi dalam dunia pendidikan saat ini adalah terjadinya pandemi Covid-19. Dan inilah yang memerlukan adaptasi baru dalam pendidikan dan proses yang mesti ditemukan dan mahir diimplementasikan. Salah satu adaptasi dalam dunia pendidikan adalah On line Course pembelajaran lewat dunia maya ini, yang diperkirakan oleh banyak pakar pendidikan sebagai simbol masa depan pendidikan Indonesia dan dunia.

\section{Bergesernya Kelas Offline Ke Online}

Ruang kelasa konvensional terdiri dari beberapa elemen atau unsur yang saling berkaitan, tergantung dan mempengaruhi, yakni guru, murid dan manajemen sekolah (Damsar, 2011). Proses bergesernya ruang kelas konvensional ke virtual atau on line leraning menegaskan bahwa proses pembelajaran dapat terjadi kapan dan di mana saja. Dan lebih menegaskan pula bahwa proses belajar mengajar tidak selalu berada ruang kelas mewah , nyaman dan berfasiltas lengkap. Sudah sekian lama pendidik dan peserta didik terlibat sangat lama dalam pendidikan konvensional.

Tak mudah meninggalkan kebiasaan lama. Begitu juga pendidik dan peserta didik tak mudah meninggalkan kebiasaan kelas konvensioanl yang sudah dianut sangat lama. dan dianggap ampuh dalam mencapai tujuan pembelajaran karena dapat berinteraksi langsung, mengamati langsung, saling menyapa dan bersentuhan. Banyak guru sulit bergerak ke on line karena masih terus ingin menggunakan cara-cara lama yang jauh dari di zaman 
siswa sesungguhnya berada yaitu dunia teknologi. Kebiasaan lama seperti mengandalkan teks book dan gagap penggunaan teknologi, guru tidak bisa computer alias TBC, serta guru nifas atau nihil penggunaan fasilitas. Guru tidak lain adalah sosok yang dapat menghilangkan hambatan belajar peserta didik (Alamsyah, 2021).

Zaman itu tiba, dan tak bisa ditolak. Dialah pandemi Covid 19, dia ibarat "Juggernaut" seperti sebuah situasi yang mengerikan, melindas siapa saja yang dilewati, tak ada ampun, termasuk dalam pendidikan. Hanya proses pendidikan satu-satu cara menciptakan Sumber daya manusia unggul dengan cara apaun dan situasi apapun. Pendidikan dan manusia ibarat dua kata kembar tak terpisahkan satu sama lain. Pendidikan maju karena manusianya, manusia maju karena pendidikannya.

Petuah bijak mengatakan setiap zaman ada pemimpinnya dan setiap pemimpin ada zamannya. Begitulah zaman dan pemimpinya berevolusi. Setiap pemimpin memiliki khas kepemimpinanan sesuai keinginan zamanya. Tak terkecuali kepemimpinan dan zaman dalam sektor pendidikan. Ki Hhadjar Dewantara selaku mendikbud memimpin pendidikan sesuai keadaan miliu pendidikan waktu. Begitu juga Bapak Nadiem Anwar Makarim selaku Mendikbud memimpin pendidikan sesuai keinginan dan kebutuhan zamannya.

Ki Hadjar Dewantara memilih perjuangannya mengkritik keras dan terang-terangan pemerintah Belanda atas ketidakadilannya pada rakyat Indonesia. Ki Hadjar Dewantara sangat menyadari bahwa demagogi (hasutannya) yang dialamatkan kepada kebijakan pemerintah Hindia belanda tidak menutup kemungkinan nyawa dan penjara jadi taruhannya. Tapi urat nadi 
ketakutannya telah tercabut atas kegigihannya memperjuangkan kesetaraan rakayat mengenyam pendidikan. Singaktnya, Bapak Ki Hadjar Dewantara telah meletakkan blut print pendidikan yang bertinta emas di zamannya.

Sedangkan di bawah komando Mendikbud bapak yang mulia, bapak Menteri, Nadiem Anwar Makarim, salah satu menteri oleh bapak Presiden RI disebut Menteri millennial. Yang saat tengah berjuang menghadapi ganasnya pandemi covid 19 yang tak kunjung surut . Dan di saat sama seluruh insan pendidikan tanah air masih menanti, menaruh harapan dan lompatan besar, ketuk palu sang menteri demi kemajuan pendidikan bumi pertiwi Indonesia . Metode lama tak dapat diandalkan mengawal proses pembelajaran saat ini. Kebijakan pembelajaran on line akan mengulangi segregasi (pemisahan) peserta didik antara orang kaya dan miskin, pedesaan dan perkotaan.

Kejenuhan yang dialami oleh peserta belajar dalam pembelajaran daring dapat menimbulkan emosi-emosi negatif. Emosi-emosi negatif dapat dipicu oleh perilaku guru, seperti guru mengajar seolah-olah dalam suasana konvensional, memberi tugas terlalu banyak, kurangnya sentuhan hubungan sosial guru. Sementara kesulitan belajar yang dirasakan siswa selama Pembelajaran jarak jauh (PJJ), antara lain kesulitan menjawab soal, kesulitan memahami materi, kurang konsentrasi, kurang konsentrasi, dan materi yang kurang jelas. Siswa juga mengeluhkan guru yang memberikan banyak tugas serta tidak mengembangkan pembelajaran yang menyenangkan dan koloboratif yang mendorong siswa dapat merasakan interaksi bersama. Hasil survei yang kondisi sosial emosional siswa ini dilakukan oleh Gerakan Sekolah Menengah (GSM) dengan responden 
1.599 siswa SD, SMP dan SMA/SMK . Survei digelar pada awal April 2021 untuk mengevaluasi pendidikan di masa depan.

\section{Kesimpulan}

Adaptasi pembelajaran terhadap bergesernya kelas off line ke on line dalam peningkatan sumber daya unggul bukan hanya sekedar memindahkan ruang kelas, metode , gaya pembelajaran tapi yang paling penting dan utama adalah adaptasi atau penyesuaian mental, perilaku, pola pikir, serta sikap. Dengan demikian hambatan belajar dan mengajar yang dialami pendidik dan peserta didik seperti kejenuhan, kebosanan dan emosi negatif lain dapat teratasi sebab realitas sosial dalam pendidikan dan pembelajaran on line hari ini adalah sebuah keciscayaan.

\section{Daftar Pustaka}

Anonim, 2021. Siswa Perlu Sentuhan Emosi, Jakarta: Edisi Kompas Jumat/6/82021

Alamsyah, 2021. Belajar dan Pembelajaran serta Pengembangan Kurikulum, Seminar Nasional Prodi Penjas FKIP Univ. Megarezky.

Damsar. 2012. Pengantar Sosiologi Pendidikan. Jakarta: Prenada Media

Iskandar, A Malik, 2021. Praktik Sosial Pengemis Perkotaa, Yogyakarta : Bintang Surya Madani

Iskandar, A Malik, 2020. Dua Mendikbud berbeda Zaman : Ki Hadjar Dewantara VS Nadiem Anwar Makarim , Makassar : Opini Tribun Timur.

Setiadi, M. Elly \& Kolip , Usman, 2010. PENGANTAR SOSIOLOGI Pemahaman Fakta dan Gejala Permasalahan Sosial: Teori, Aplikasi \& 
Pemecahannya. Rawamangun, Jakarta: Kencana Prenada Media Group. 


\title{
SUMBER DAYA MANUSIA UNGGUL PADA \\ SAAT PANDEMI \\ “PENDIDIKAN DI ERA PANDEMI COVID-19"
}

\author{
Tarisha Zetha Maharani ${ }^{14}$ \\ Universitas PGRI Semarang
}

"Pembelajaran dalam jaringan tentunya memiliki beberapa keunggulan. Bagaimana implementasi pendidikan di era pandemi covid-19?

Dam era pandemi ini, dimana Kerja keras para guru selama ini sungguh patut diapresiasi. Di tengah pembatasan sosial akibat wabah covid-19, mereka tetap semangat mengejar dan mengajar ilmu pengetahuan. Hampir tidak ada yang menyangka, wajah pendidikan akan berubah drastis akibat pandemi Covid-19.

Sedangkan, konsep sekolah di rumah (home-schooling) tidak pernah menjadi arus utama dalam wacana pendidikan nasional. Meski makin populer, penerapan pembelajaran online (online learning) selama ini juga terbatas pada Universitas PGRI Semarang, program kuliah bagi karyawan di sejumlah universitas dan kursus-kursus tambahan (online courses).

Tapi, kebijakan physical distancing untuk memutus penyebaran wabah, memaksa perubahan dari pendidikan formal di bangku sekolah menjadi belajar dari rumah,

14Tarisha Zetha Maharani, Fakultas Ilmu Pendidikan Universitas PGRI Semarang 
dengan sistem online. Sistem pendidikan online tentu tidak mudah. Di samping disiplin pribadi untuk belajar secara mandiri, ada fasilitas dan sumber daya yang mesti disediakan.

Mencermati kondisi yang sampai saat ini belum juga ada kepastian kapan masa pandemi akan berakhir, yang sudah berlangsung 18 bulan sejak medio Maret 2020, tentu diperlukan langkah-langkah strategis terkait pelaksanaan pembelajaran di masa transisi pandemi ini. Langkah ini dipandang sangat penting karena jika tidak ada persiapan matang sejak awal, maka dimungkinkan akan terjadi loss generation atau bahkan education death (kepunahan pendidikan). Dalam arti pendidikan sebagai sebuah proses yang membersamai pembelajaran tidak hadir secara nyata (induktik) atau bahkan punah sama sekali.

Dengan sistem pembelajaran jarak jauh , kemungkinan akan timbul beberapa masalah-masalah dalam berlangsungnya proses pembelajaran. Tentunya peserta didik maupun tenaga pendidik dari semua kalangan diharuskan memiliki akses jaringan internet yang baik. Namun, banyak daerah-daerah yang memiliki akses internet kurang baik atau tidak lancar sehingga menjadi salah satu kendala berlangsungnya kegiatan belajar mengajar dengan baik.

Selain itu, tidak sedikit peserta didik yang tidak mendapatkan hasil pembelajaran secara maksimal. Baik dari materi pelajaran maupun penugasan-penugasan yang diberikan oleh tenaga pendidik selama pandemi Covid-19 ini berlangsung. 


\section{Unggul}

Pembelajaran online (daring) memang unggul dalam feasibility waktu dan tempat, bisa dari mana saja dan kapan saja. Namun demikian bukan berarti tanpa kelemahan, misalnya : cepat lelah, capek, kurang induktif, kurang kontekstual, tidak bisa utuh, interaksi semu dan terutama sulit untuk menjangkau implementasi PPK (Penguatan, Pendidikan Karakter) bagi pembelajar.

Dengan sistem pembelajaran jarak jauh, peserta didik tidak diharuskan atau diwajibkan untuk datang ke sekolah maupun kampus untuk melaksanakan pembelajaran. Banyak sarana yang pada akhirnya diterapkan oleh tenaga pendidik untuk melaksanakan kegiatan belajar mengajar secara jarak jauh. Sarana pembelajaran jarak jauh tersebut tidak dapat dihindari dari perkembangan teknologi informasi dan komunikasi.

Di masa adaptasi kebiasaan baru masa Covid-19 ini, hemat saya dapat dijadikan momentum untuk kebangkitan pendidikan kita sekiranya seluruh pemangku kepentingan pendidikan di negeri ini saling bergotong-royong. Menanggalkan egoisme sektoral antarkementerian.

Diterbitkannya SKB 4 Menteri : Menteri Pendidikan dan Kebudayaan, Menteri Agama (Menang) Menteri Kesehatan (Menkes) dan Menteri Dalam Negeri (Mendagri) tentang penduan Penyelegaraan Pembelajaran Semester Genap Tahun Ajaran dan Tahun Akademik 2021/2022 perlu diterjemahkan secara bijak oleh banyak pihak, khususnya penyelenggara lembaga pendidikan dan pembelajar, baik siswa sekolah dasar, menengah maupun mahasiswa di perguruan tinggi. 
Tugas mencerdaskan dan membuat bangsa ini berkarakter itu bukan hanya Kementerian Pendidikan dan Kebuyaaan, apalagi di masa Covid-19. Tentu, masalah koneksi internet semestinya menjadi domain Kementerian Komunikasi dan Informasi, lalu masalah kesehatan jelas berada di koordinasi Kementerian Kesehatan. Sekiranya kementerian kementerian saling bahu-membahu mempersiapkan infrastrukturnya maka tidak ada yang mustahil membangun kualitas intelektualitas peserta didik yang tetap sehat di masa adaptasi kebiasaan baru era Covid19.

Praktik pendidikan di era digital memerlukan inovasi dan kreasi yang terus-menerus sehingga guru maupun anak didik tidak mudah mengalami kejenuhan dan kebosanan. Pun jangan dimaknai pembelajaran daring sekadar memberikan sekian soal kepada murid untuk menjawabnya. Kalau ini yang terjadi maka pembelajaran yang membebaskan dan berkarakter akan berhenti di slogan tanpa pernah diketahui spirit di dalamnya. Oleh karena itu belajar sesungguhnya tidak pernah berhenti sejak dari dalam kandungan hingga ke liang lahat.

Namun, di samping beberapa kendala yang muncul terdapat beberapa hikmah yang dapat diperoleh dari pandemi Covid-19 tanpa kita sadari. Dengan sistem pembelajaran yang dilaksanakan secara jarak jauh, di mana peserta didik banyak melakukan kegiatan di rumah sehingga dapat mempermudah para orang tua untuk memonitoring anak-anaknya.

Selain itu, dari sisi kreativitas baik dari tenaga pendidik maupun peserta didik dalam sistem pembelajaran jarak jauh dituntut untuk berlaku kreatif. Sebagai contoh tidak sedikit tenaga pendidik membuat materi pembelajaran yang 
disajikan dalam bentuk video-video pembelajaran. Selain itu, tidak jarang pula pesera didik yang mendapatkan penugasan pembuatan video pembelajaran yang menarik.

Pada dasarnya pandemi Covid-19 memberikan dampak-dampak yang dapat melemahkan aktivitas manusia pada umumnya. Tidak dapat dipungkiri pada awalnya banyak masyarakat yang beranggapan bahwa masa pandemi Covid-19 adalah masa yang menyulitkan umat manusia. Tanpa kita sadari banyak sisi-sisi positif yang dapat kita petik dari pandemi Covid-19 yang sedang melanda dunia hingga hari ini.

Dampak yang dirasakan memang sangat nyata dan dapat dirasakan oleh setiap orang. Namun, masyarakat tidak bisa menjadikan pandemi Covid-19 sebagai sebab untuk tidak melaksanakan kegiatan terutama dalam bidang pendidikan.

Kita sangat berharap Pandemi Covid 19 bisa segera berakhir, sehingga sekolah bisa dimulai lagi. Dan seluruh peserta didik dan juga pendidik, bisa melakukan pembelajaran secara wajar yaitu secara tatap muka. Karena ikatan antara Peserta didik dengan Pendidik tidak bisa digantikan dengan teknologi pembelajaran virtual.

\section{Daftar Pustaka}

I Wayan Eka Santika. (2020). Pendidikan Karakter pada Pembelajaran Daring. Indonesian Values and Character Education Journal, 3(1). 


\title{
PERAN KELUARGA DALAM MENCIPTAKAN SDM UNGGUL DI MASA PANDEMI COVID-19
}

\author{
Muhammad Al Mansur, S.Sy., M.I.S ${ }^{15}$ \\ STAIN Bengkalis
}

\begin{abstract}
"Revolusi pendidikan di masa pandemi covid-19 sangat bergantung pada peran keluarga dan lingkungan sekitar untuk menciptakan sumber daya manusia yang unggul"
\end{abstract}

Gudah lewat satu tahun setengah, wabah virus covid-19 $\mathcal{S}_{\text {ini melanda seluruh dunia tanpa terkecuali di Negara }}$ Kesatuan Republik Indonesia ini, namun roda sistem pemerintahan normal belum bisa dilaksanakan kembali akibat perkembangan wabah covid-19 ini semakin tinggi. Terutama pada bulan juli 2021 kemaren, kasus positif covid-19 mengalami pelonjakan yang sangat drastis, pada tanggal 15 Juli 2021 kasus yang terkonfirmasi posisitf covid19 mencapai statistic level tertinggi dengan jumlah 56.757 kasus positif.

Terhitung mulai maret tahun 2020 kemaren, hingga saat ini menurut data yang dihimpun oleh Badan Nasional Penanggulangan Bencana (BNPB) dan dilansir oleh covid19.go.id pada 22/08/2021, jumlah keseluruhan kasus

15Muhammad Al Mansur, S.Sy., M.I.S. Lahir di Bengkalis, 10 Mei 1991 Penulis merupakan Dosen STAIN Bengkalis dalam bidang Hukum Keluarga Islam (Ahwal Syakhshiyyah). Penulis menyelesaikan gelar Sarjana Syari'ah di Fakultas Syariah dan Hukum, Universitas Islam Negeri (UIN) Syarif Hidayatullah Jakarta (2013) dan gelar Master Of Islamic Studies diselesaikan di Jabatan Syari'ah, Fakulti pengajian Islam, Universiti Kebangsaan Malaysia (2017). 
Covid-19 mencapai 3,979.456 kasus. Jumlah ini didapat setelah adanya penambahan kasus hari ini berjumlah 12.408 kasus positif covid-19. Disebabkan adanya pelonjakan inilah, sistem pendidikan dan pengajaran di Indonesia kembali dilaksanakan secara Daring (dalam jaringan) walaupun di awal tahun 2021 pemerintah sempat membolehkan sistem pendidikan dan pengajaran menggunakan tatap muka untuk wilayah zona hijau.

Seiring dengan pelonjakan penyebaran covid-19 akhirakhir ini, membuat pemerintah kembali melalukan sistem pendidikan dan pengajaran dalam jaringan. Hal ini juga yang menjadi keluhan bagi para orang tua dan keluarga karena mereka harus mengurusi, mengajar dan mendidik anaknya masing-masing di rumah dengan bimbingan guru anaknya masing-masing. Bagi anak-anak yang memiliki orang tua yang berpendidikan serta tanggung jawab yang tinggi, mereka dengan berbagai macam cara memberikan dan mengajari anak-anaknya masing-masing di rumah sehingga anak-anak tetap mendapatkan pendidikan yang baik sehingga menjadi unggul.

Namun, terdapat di sebagian wilayah terpencil, termasuk yang berada di pedalamn dan pinggiran pantai, terdapat orang tua dan keluarga yang kurang berpendidikan (dahulunya tidak mengenyam masa pendidikan sekolah) sehingga mereka tidak ambil peduli terhadap pendidikan dan pengajaran terhadap anak-anak mereka terutama di saat masa pandemic covid-19 ini. Apalagi mereka yang juga dihantam dengan masalah perekonomian, sehingga mereka harus lebih giat pergi menjaring ikan di lautan daripada focus di rumah mendidik dan mengajari anak-anak mereka. Hal ini pula yang membuat banyak anak-anak yang tidak mahu melanjutkan pendidikan dan ikut membantu ayahnya 
pergi ke laut untuk menjaring ikan dan menambah penghasilan uang.

Dengan adanya berbagai persoalan ini, perlu untuk penulis mencari cara dan solusi dalam menangani masalah ini. Salah satunya adalah melihat kembali peran orangtua dan keluarga dalam menciptakan SDM unggul pada masa pandemic covid-19 ini. Banyak sekali penelitian yang dilakukan dikalangan guru dan akademisi pendidikan terkait dengan peran orang tua dalam pembelajaran di masa daring, diantaranya adalah di jenjang pendidikan taman kanak-kanak (TK), peran orang tua dalam belajar daring adalah Pertama, mendampingi peserta didik dalam setiap proses pembelajaran, Kedua, memfasilitasi peserta didik dalam melalukan seluruh kegiatan pembelajaran dan ketiga, adalah memotivasi peserta didik agar mereka tetap merasa senang dan gembira menyelesaikan pembelajaran dengan baik. (Nurhasanah R, 2020).

Hasil penelitian (Riana Denik Ratiwi \& Woro Sumarni, 2020) terdapat beberapa peran orang tua dalam pembelajaran daring yaitu: 1. Mendapingi, 2. Menjalin Komunikasi, 3. Mengawasi, 4. Mendorong atau Memberi Motivasi dan, 5. Mengarahkan. Hasil dari peneliatian tersebut adalah bahwansya proses pembelajaran daring telah menghambat perkembangan kognitif anak-anak, mereka sulit menguasai materi, tidak efektif seperti di sekolah, anak-anak merasa bosan belajar di rumah, dan keterbatasan jaringan dalam melaksanakan pebelajaran daring.

Keluarga merupakan asas pembentukan yang utama terhadap karakter anak. Lingkungan yang pertama dikenal oleh anak adalah keluarga sehingga tumbuh ekesistensi kediriannya. Dalam hal pembentukan karakter anak, 
keluarga juga merupakan unsur yang memberi kontribusi utama dan dominan terhadap kepribadian dan kecerdasan, baik emosional maupun spiritual. Pola interaksi anak juga sangat dipengaruhi oleh peran keluarga (Rohmat, 2010) sehingga dalam hal pendidikan dan pengajaran terhadap anak juga bukan hanya tugas seorang ayah, atau hanysa seorang ibu, namun harus dilakukan oleh keseluruhan anggota keluarga sehingga berhasil menciptakan SDM unggul terutama pada masa pendemi covid-19 ini.

Menurut (Puspitawati, 2012), keluarga merupakan unit social terkecil dalam masyarakat dan merupakan landasan dari semua institusi. Keluarga merupakan unsur/kelompok yang terdiri dari dua orang atau lebih yang terikat dengan hubungan dan interaksi interpersonal, hubungan perkawinan, hubungan darah dan adopsi. Dengan ikatan keluarga, seluruh anggota keluarga diharuskan tinggal bersama-sama di dalam satu rumah. Kemudian, kepala keluarga biasanya selalu ditujukan kepada suami atau seorang ayah, hal ini sesuai dengan UU No. 1 tahun 19974 tentang Perkawinan. Kemudian seluruh anggota keluarga memainkan peran dan terlibat dalam kesatuan komunikasi dan interaksi baik itu sebagai istri dan suami, anak dan orang tua, maupun anak dan saudara/adik beradik. (Amorisa Wiratri, 2018)

Di masa sekarang ini, keluarga menjadi tolak ukur terhadap keberhasilan regenerasi yang diciptakan. Keluarga menjadi patokan terhadap keberhasilan anak-anak di masa mendatang. Keluarga menjadi landasan utama menciptakan sumber daya unggul di masa sekarang dan yang akan datang. Adapun SDM unggul yang dimaksud adalah sumber daya manusia yang berkualitas di semua bidang keahlian dan profesi. Dengan harapan, generasi unggul ini akan 
menjadi pemenang dalam kompetisi antara bangsa di masa pandemic ini dan di masa mendatang, menang menjadi bangsa yang unggul dalam bidang kualitas dan kuantitas seluruh produk, baik dari segi ekonomi, budaya dan ilmu pengetahuan teknologi. Dengan kata lain, keunggulan ini tidak hanya tetrumpu kepada kekayaan alam, melainkan kepada keunggulan sumber daya manusia yaitu orangorang yang menjadi tenaga yang terdidik sehingga mampu menjawab dengan sangat cepat seluruh tantangantantangan yang dihadapi. Dan tentunya yang menjadi tujuan utama adalah menghasilkan SDM yang dapat memacu pembangunan bangsa lebih cepat. (Dhikrul Hakim, TT)

Di masa pandemic Covid ini, kita semua dituntut lebih extra dalam menciptakan generasi unggul. Hal ini disebabkan adanya sistem sistem pembelajaran dalam jaringan (Online) sehingga antara guru dan murid serta orang tua dan keluarga harus saling bekerja keras demi tercapainya amanat kurikulum. Terutama pihak keluarga harus lebih fokus dalam melaksanakan proses pembelajaran dalam jaringan ini. Adapun peran keluarga dalam menciptakan SDM unggul di masa pandemic covid ini adalah sebagai berikut:

Pertama, Peran keluarga dalam meningkatkan kemampuan akademis anak-anak. Baik itu keterampilan, sikap, mental dan kepribadian lainnya. Dalam proses meningkatkan kemampuan ini, suami dan istri harus saling bekerja sama dalam melaksanakan proses ini. Dimulai dari mendisiplinkan anak-anak terhadap waktu belajar mereka, kemudian melakukan pengawasan yang ketat dalam proses pembelajaran online sehingga mereka mampu memahami materi dan kurikulum yang diberikan. Orang tua tidak boleh menganggap remeh terhadap pembelajaran online karena 
bisa mengakibatkan kemunduran yang fatal terhadap anakanak. Jikaperlu apabila sang ayah atau sang ibu tidak bisa memberikan pemahaman kepada anak tentang pelajaran tersebut, maka orangtua harus mencari solusi lain dengan mendatangkan guru atau tenaga pakar ke rumah agar sang anak bisa menguasai materi belajarnya.

Kedua, Orang tua harus berusaha meningkatkan mutu anak-anaknya dengan cara mendampingi anak-anaknya untuk meningkatkan pengetahuan, keterampilan, dan keahlian sesuai dengan kualifikasi yang dipilih di semua jenjang pendidikan dengan pemahaman materi yang bebrobot fan mendalam, baik pada jenjang sekolah menengah pertama sampai sekolah menengah atas dan perguruan tinggi. Sehingga anak-anak tersebut menguasai seluruh pengetahuan, keterampilan dan keahlian sesuai dengan kebutuhan pasar atau lapangan pekerjaan. Diantara contoh keahlian yang dibutuhkan di dunia internasional adalah penguasaan bahasa asing, seperti bahasa Inggris dan lainnya, kemudian keterampilan dalam menggunakan teknologi modern, dan kemudian penguasaan ilmu-ilmu lainnya. Lagi-lagi orang tua dan keluarga harus bekerja sama dan lebih ekstra dalam meningkatkan kemahiran sesuai dengan kecakapan, minat dan bakatnya masingmasing.

Ketiga, Selain dari dimensi pendidikan, orang tua juga optimal dalam mengawasi, mendampingi serta mengarahkan pertumbuhan kreativitasnya. Sehingga anakanak tersebeut tidak mengalami stagnan dalam berinovasi dan berkreatifitas. Banyak sarana dan prasarana di rumah yang bisa digunakan untuk meningkatkan kreatifitasnya seperti penggunaan barang elektronik maupun yang lainnya. Kemudian komunikasi yang baik harus tetap terjaga 
antara orang tua dan anak sehingga anak-anak tumbuh secara sempurna dengan kerangka berfikir yang baik tanpa ada kejanggalan, ajak anak-anak kita untuk selalu berfikir dan memunculkan ide-ide mereka masing-masing. Kemudian libatkan mereka dalam pengambilan keputusan sehingga hal ini berpengaruh terhadap mental dan kepercayaan dirinya. Orang tua harus menjadi pendengar yang baik, harus mengajarkan tenang dan jujur, aktif komunikasi dua arah, tidak mengghujani pertanyaan betubi dan terkahir selalu memberikan motivasi kepada anak. Wallahu a'lam

\section{Daftar Pustaka}

Hakim, Dzikrul,. Makna Strategis Pendidikan Unggul Menyongsong Pasar Tunggal Asean 2015. Paper Literatur review. https://media.neliti.com/media/publications/1702 77-ID-makna-strategi-pendidikan-unggulmenyong.pdf

Nurhasanah R, 2020. Peran Orang Tua Dalam Pembelajaran Daring Di Masa Pandemi Covid19 Pada kelompok B.5 TK Kemala Bhayangkari Bone. Jurnal Educhild, Vol. 2 No. 2 Desember 2020.

Ratiwi, Riana Denik., Sumarni, Woro., Peran Orang Tua Dalam Pendampingan Pembelajaran Daring Terhadap Perkembangan Kognitif. Paper Seminar Nasional Pascasarjana UNNES 2020. ISSN: 2686 6404

Rohmat,. Keluarga dan Pola Pengasuhan Anak. Jurnal Studi Gender dan Anak YINYANG Vol. 5 No.1 Jan-Jun 2010 pp.35-46. ISSN: 1907-2791

Puspitawati, H. (2012). Gender dan Keluarga: Konsep dan Realita di Indonesia. Bogor: PT. IPB Press. 
Wiratri, Amorisa,. Menilik Ulang Arti Keluarga Pada Masyarakat Indonesia (Revisiting The Concept of Family In Indonesian Society). Jurnal Kependudukan Indonesia. Vol.13 No. 1 Juni 2018 e-ISSN: 2502-8537 


\title{
HIGHLIGHTING HUMAN RESOURCES \\ (TEACHER) PERFORMANCE IN THE MIDST OF \\ PANDEMIC COVID 19
}

\author{
Rezza Ayatillah Velayati, S.Pd 16 \\ SMAN 2 Probolinggo
}

"The change in learning methods from offline to online certainly has an impact on students, teachers must improve their performance to compensate for the spread of covid 19"

Education is one of the most essential aspects of a
person's life. Education becomes a community necessity as the times progress. Education is primarily a purposeful and planned effort to create the learning environment and learning process so that learners actively develop their potential for spiritual, religious, self-control, personality, and intelligence. Teacher is a crucial thing and the most important part in formal education because teacher act as role models for students and even become their parents in school. Education's implementation performance was positively decided by their preparation. Teacher need to prepare their students by participating in teaching and learning activities. There are several strategies that a teacher may use to improve the quality of education as well.

16Penulis lahir di kabupaten Lumajang, 07 Juli 1993, penulis merupakan GTT di SMA Negeri 2 Probolinggo sebagai guru Bahasa Inggris, penulis menyelesaikan gelar Sarjana Pendidikan Bahasa Inggris di Universitas Muhammadiyah Malang (2016). 
Meanwhile, in early 2020, the world was scared by the corona virus (COVID-19), which attacks the human respiratory system which causes a crisis. The corona virus started in Wuhan, China. In March 2, 2020, this was the first time the corona virus entered Indonesia. Corona virus' infection spread quickly, and the frequency of COVID-19 cases in Indonesia is also increasing quickly. Nowadays, health is the most important thing for human's life. The government has a policy that one of them is to prohibit activities outside the house such as schools, shopping centres, tourist areas, highways, and others. All activities that were previously done outside the house turned into inside the house, including working at home and school becomes online learning using online applications. Through letter No. 32020 on COVID-19 Prevention, followed by a Minister of Health's Letter No. HK.02.01/MENKES/199/2020 on March 12, 2020, and the Secretary General's Kemendikbud No. 36603/A.A5/OT/2020 on March 15, 2020. Based on the letter, the Minister of Education and Culture made that decision on prevention efforts and the spread of COVID-19.

All face-to-face learning activities both school and college are closed until an undetermined time of limit and changed to distance learning using pre-existing online applications. Teachers are also affected by this pandemic, which requires them to teach from home in other words not to attend school.

There are 4 serious problems that are very destructive with online teaching and learning activities for students and even the teacher. The first one is the limitation of facilities such as mobile phones or mobile phones, which are essential to support teaching and learning activities or 
receiving materials via online. Second, the signal or network by itself. Learning activities will be affected if both students and teachers receive a good signal. Then, teacher's technical skill. Teachers are expected to understand how to provide material via online because teaching and learning activities will be disrupted if teachers do not have technological skills. Last, it takes a time. Sometimes in cases, achieving students' needs in the form of materials or learning materials takes no time to access, which is quite different from face-to-face learning. Moreover, Kompasiana summarized into a chart that some of the difficulties that exist in online learning make students less interested in online learning.

Figure 1: Students have a low interest in learning. Students think online learning is monotonous and only provides a lot of assignment.

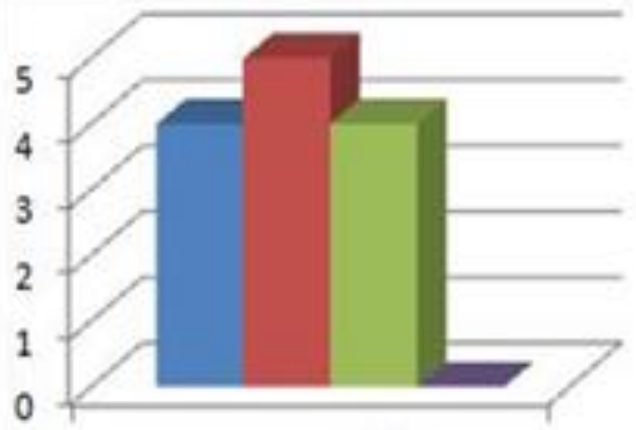

I rendah sekali

wrendah

sedang

를 tinggi

minat siswa dalam

pembelajaran daring di

sekolah

Kumparan.com conducted an open survey to the majority of schools in the Jabodetabek area, questioning about teacher performance during the pandemic, in response to students' declining motivation in studying during the pandemic. 
Table 1. Teacher Performance

\begin{tabular}{clll}
\hline No & Seaktif apakah guru saat Pembelajaran Jarak Jauh & Jawaban \\
\hline $\mathbf{1}$ & $\begin{array}{l}\text { Sangat Aktif (menjelaskan materi melalui } \\
\text { presentasi PPT dan mengadakan sesi tanya jawab) }\end{array}$ & $34,5 \%$ \\
\hline $\mathbf{2}$ & $\begin{array}{l}\text { Cukup aktif dengan hanya menerangkan materi } \\
\text { saja. }\end{array}$ & $44,1 \%$ \\
\hline $\mathbf{3}$ & $\begin{array}{l}\text { Kurang Aktif, hanya sekedar memberikan materi } \\
\text { tanpa menjelaskannya }\end{array}$ & $21,4 \%$ \\
\hline
\end{tabular}

According to the table above, online learning is quite understandable by most students. However, we cannot make decisions based on one point of view. Teachers face a difficult situation because they are being prosecuted to maintain their professionalism in the face of all changes to the education system even in this pandemic.

Many teachers work hard to keep their professionalism while working from home. Teachers will not stay quiet after understanding that their performance in the current pandemic is worsening. In addition to the professional demands of a sense of belonging, the responsibility to the nation's next generation requires the teacher to continue to improve their performance in the following ways:

1. Lesson Planning and Teaching Material

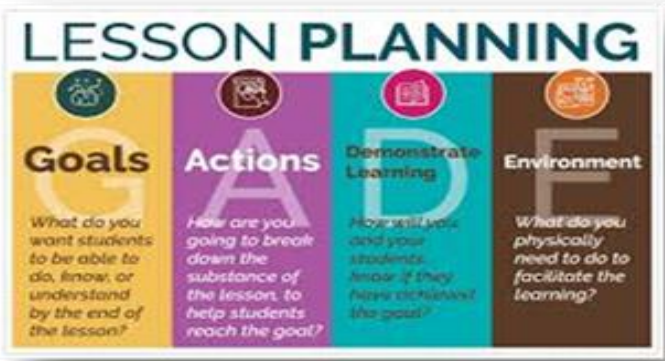

Picture 1: Lesson Plan 
Although students study at home, each teacher ensures that a learning plan and teaching materials are already in place in order to improve the quality of the learning process. Of course, the learning plan and teaching materials are adapted to the current conditions.

2. Mentoring and Evaluation

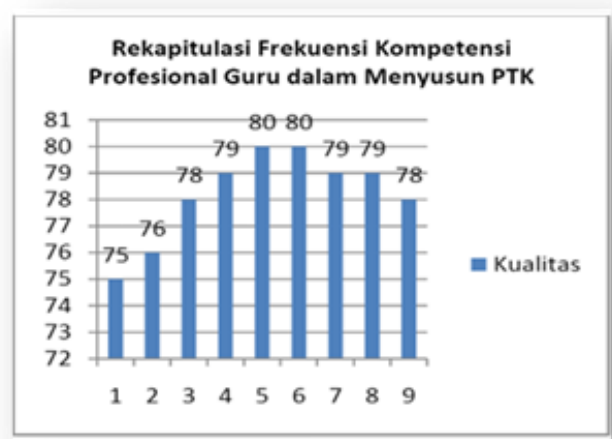

Figure 2: Teacher evaluation recapitulation data

Following the plan for the implementation of learning and teaching materials, and finally the evaluation is carried out to identify what needs to be improved and in order to improve the quality of learning in the future especially in the midst of Pandemic Covid-19.

Based on the arguments and facts presented above, it is possible to conclude that teacher performance during the pandemic is less than optimal. Each person has their own problem. Learning is regarded as less effective. This is due to various of problems, including most of the teachers who still do not understand what to do to use modern technology applications, and otherwise distance, that is a big problem 
in learning during this pandemic due to a lack of interaction between teachers and students.

This indicates that teachers have made various efforts to establish communication and interaction with online systems during this pandemic, but this takes effort because teachers are also required to provide objective assessments of student learning achievement due to various problems in the processes.

\section{Daftar Pustaka}

Usman, M. Uzer. 2010. Menjadi Guru Profesional. Bandung: PT. Remaja Rosda Karya. Fattah, Nanang. 2003. Landasan Kependidikan. Bandung: PT Remaja Rodaskarya.

Sarah Busyra \& Lutfiah Sani. 2020. "Kinerja Mengajar dengan Sistem Work From Home (WFH) pada Guru di SMK Purnawarman Purwakarta" Jurnal Pendidikan Islam / Volume 3 No. 012020

Priansa, D. J. (2018). Kinerja dan Profesionalisme Guru. Bandung: CV Alfabeta

Haryati, S. (2020). Kepuasan Belajar Siswa Di Masa Pandemi Covid-19 Ditinjau Dari Kompetensi Profesional Guru Dan Fasilitas Belajar (Doctoral dissertation, Universitas Pancasakti Tegal).

Kompasiana. 2020. Pembelajaran daring efektif? .https://www.kompasiana.com/arditasyalwa/5e7b a8d6097f36116506b8a2/ pembelajarandaringefektif. diakses pada 20 Agustus 2021

Kumparan. 2021. Pembelajaran Jarak Jauh efektif atau tidak?. https://kumparan.com/artanti-zahraadisa/pembelajaran-jarak-jauh-efektif-atau-tidak1uzmY60tFla/full. Diakses pada 20 Agustus 2021 
Burd, B. \& Buchanan, L. (2004), Teaching the teachers: teaching and learning online. Reference Services Review, 32 (4): 404-412. https://doi.org/10.1108/ 00907320410569761

Chakraborty, M. \& Muyia Nafukho, F. (2014). Strengthening student engagement: what do students want in online courses?. European Journal of Training and Development, 38(9), 782-802. https://doi.org/10.1108/ EJTD-11-2013-0123

Deshwal, P., Trivedi, A., \& Himanshi, H. L. N. (2017). Online learning experience scale validation and its impact on learners' satisfaction. Procedia computer science, 112, 2455-2462.

Doi:

https://doi.org/10.1016/i.procs.2017.08.178

Kurniawati, Nia. 2021. Implementasi Merdeka Belajar dimasa Pandemi Covid 19: Peluang dan Tantangan. Fakultas Keguruan dan Ilmu Pendidikan Universitas Lampung. 


\title{
TEKNIK DICSTOM, TRIAL WEB DESIGN, DAN ENGAGEMENT STRATEGY, SEBAGAI METODE ALTERNATIF MENINGKATKAN KEMAMPUAN MAHASISWA MENULIS TEKS SEJARAH ISLAM MENGGUNAKAN BAHASA INGGRIS SELAMA PANDEMI COVID-19
}

\author{
Joni Helandri, M.Pd 17 \\ STAI Bumi Silampari
}

"Keterampilan literasi sepatutnya ditekankan kepada mahasiswa untuk mengasah kemampuan berbahasa. Melalui

berbagai alternatif metode yang bervariasi dapat memecahkan problematika yang menjadi boomerang selama pandemi covid-19”

\begin{abstract}
$\mathrm{M}$ enulis bahasa inggris dalam konteks akademik untuk mahasiswa menjadi kesulitan tersendiri. Banyak faktor yang melatarbelakangi kesulitan yang ada tersebut antara lain adalah mengharuskan mahasiswa untuk memanfaatkan sumber luar dan mengadopsi gaya dan genre wacana akademik yang ada. Selain itu mahasiswa juga diharuskan untuk melakukan penelitian, meringkas, memparafrase, mengutip sumber, serta memenuhi harapan pembaca untuk memilih kata, dan menerapkan pola tata bahasa. bahwa ciriciri genre tulisan yang kurang personal dan lebih formal.
\end{abstract}

17Penulis menyelesaikan gelar sarjana di IKIP Mataram, majoring in English Education, gelar magister di Universitas Sriwijaya, dan gelar doctor di Universitas Bengkulu. 
Tardy dan Courtney (2008:73) mengatakan bahwa keterampilan literasi akademik dapat menimbulkan tantangan saat pertama kali diperkenalkan. Dalam melakukan penelitian, mahasiswa harus belajar mencari dan mengevaluasi kredibilitas dan realibilitas sumber tulisan serta mengembangkan keterampilan literasi informasi yang ada.

Fenomena yang terjadi di beberapa perguruan tinggi pada masa pendemi tentu akan menjadi tantangan tersendiri. Penulis melakukan wawancara terhadap mahasiswa semester tiga jurusan Pendidikan Agama Islam (PAI) di tempat penulis mengajar, untuk mencari penyebab kenapa kemampuan dalam menulis teks Sejarah Islam ke dalam Bahasa Inggris menurun.

Penulis menemukan jawaban yang hampir sama yaitu karena kurangnya pertemuan dan perkuliahan. Fakta menunjukkan bahwa ketika mahasiswa ditugaskan untuk menulis teks Sejarah Islam dalam bahasa inggris melalui pembelajaran dalam jaringan menggunakan platform Zoom meeting, mahasiswa mengalami kesulitan untuk menulis, mereka membutuhkan banyak waktu untuk mengerjakannya, dan berusaha keras untuk menyelesaikannya. Kesulitan-kesulitan tersebut muncul karena beberapa alasan:

1. Mahasiswa tidak dibiasakan dengan baik untuk berlatih menulis secara langsung atau offline. Artinya eksposur tulisan tidak mencukupi, hanya dibatasi beberapa jam per minggu melalui zoom. Hal ini sejalan dengan apa yang dikatakan Huda (1996:150) bahwa pengajaran bahasa Inggris di perguruan tinggi berbeda dengan pengajaran di sekolah menengah dalam banyak hal: status, jumlah 
jam, tujuan pengajaran, metode pengajaran, dan bahan ajar,

2. Mahasiswa tidak menguasai tata bahasa, artinya mereka tidak tahu banyak tentang struktur kalimat, pola kalimat, tenses, dan klausa,

3. Mahasiswa tidak memiliki kosakata, konvensi kata dan tesaurus yang cukup, terutama kata-kata yang berhubungan dengan istilah Islam,

4. Mahasiswa masih gagal melatih keterampilan menulis, sebagai proses penemuan makna yang berharga. Artinya proses penulisan tidak dilakukan secara serius, ini adalah pergeseran paradigma; dari proses ke produk. Idealnya, proses dimulai dari pemilihan topik, ide pendukung, dan kesimpulan. Ini juga mencakup apakah sebuah teks mengandung koherensi, kohesi, kesatuan, dan kelengkapan, dan

5. Mahasiswa terjebak untuk mengubah dari menulis teks pribadi menjadi menulis teks sejarah akademik formal dalam bahasa Inggris. Para siswa tidak banyak diekspos untuk menggunakan bahasa Islam dan mereka gagal untuk mengintegrasikan kata-kata umum ke dalam materi pelajaran khusus di lapangan. Dengan kata lain, siswa tidak mampu mendalami bahasa Inggris ke dalam Studi Islam khusus atau English for Specific Purposes (ESP). Sejalan dengan ide ini, Lytovchenko (2009:24) menyatakan bahwa ESP membutuhkan penguasaan terminologi yang sangat khusus dan kemampuan untuk menjelaskan proses formal saat siswa mempersiapkan kompetensi tingkat tinggi yang harus mereka tunjukkan dalam karir yang mereka pilih. Terakhir, Darwis (2013:1) menyatakan bahwa 
ESP juga merancang Lembaga Islam untuk memenuhi pandangan keislaman bagi mahasiswa untuk mengetahui lebih dalam tentang syariat Islam, dan

6. Pada masa pandemi mahasiswa kesulitan untuk mendapatkan sentuhan teknologi, seperti seperti zoom meeting, grup whatsapp, dan google meet. Oleh karena itu, banyak dari mereka yang tidak dapat mengikuti pelajaran secara teratur, dan akurat. Tampaknya Pandemi Covid 19 menjadi tantangan besar bagi mereka. Senada dengan apa yang dikatakan Daniel (2020) bahwa Pandemi COVID 19 merupakan tantangan besar bagi sistem pendidikan, mahasiswa, guru, atau dosen harus siap menerima perubahan tersebut.

\section{Teknik Dicstom, Trial Web Design, Dan Engagement Strategy}

Berdasarkan masalah dan kesulitan mahasiswa tersebut, diperlukan metode alternatif yang tepat guna dalam peningkatan kemampuan menulis teks sejarah islam dalam bahasa inggris pada masa pandemi ini. Setidaknya ada tiga tehnik alternatif yang dapat direkomendasikan yaitu teknik dicstom, tehnik trial web design, serta tehnik engagement strategy.

Menurut Harmer (2006:13) Dictogloss dan Maps digabungkan menjadi "Dicstom", merupakan tehnik melalui menyebutkan karangan kemudian dituliskan kembali dalam bentuk peta berfikir. Selain itu, Rico (2000:82) mengatakan bahwa tehnik Trial Web Shift adalah tehnik yang menggambarkan pergerakan dari bentuk tak tentu ke fokus. Tehnik yang mengujicoba melalui jaringan yang bercabang (jaringan lala-laba) atau seperti clustering / 
pengelompokkan sehingga membuat arah yang jelas. Terakhir, Beach dan Marshal (1991:137) menyatakan bahwa strategi Engagement adalah strategi yang melibatkan mahasiswa dengan teks ketika mereka mengartikulasikan reaksi emosional atau tingkat keterlibatan dengan teks. Dengan memberikan beberapa pertanyaan terkait teks sebagai panduan, siswa dapat mengeksplorasi imajinasi dan ide mereka tentang apa yang akan ditulis. Misalnya menugaskan mahasiswa menuliskan di media sosial seperti facebook, instagram dan media lainnya.

Sebenarnya sudah banyak penelitian yang terkait dengan penelitian peneliti tersebut. Pertama, Bunyamin, mahasiswa Program Pascasarjana Universitas Sriwijaya melakukan penelitian pada tahun 2009 dengan tesis berjudul "Efektivitas Penggunaan Teknik Discstom Dalam Pembelajaran Menulis Narasi Pada Siswa Kelas XI MAN 2 Palembang. Hasil penelitiannya menunjukkan bahwa ada perbedaan yang signifikan antara prestasi menulis siswa, diketahui bahwa nilai rata-rata pada pre-test adalah 40,1 dan menjadi 82,2 pada post-test. Berdasarkan temuan, penggunaan teknik Dicstom efektif dalam mengajar menulis pada siswa kelas XI MAN 2 Palembang.

Kedua, penelitian yang dilakukan oleh Ana Fitri Sri Hayati pada tahun 2004, judul skripsinya adalah "Uji Coba Teknik Web Shifting Dalam Pembelajaran Menulis Pada Siswa Kelas X SMA Negeri Sumber Harta Tahun Pelajaran 2014/2015" Skripsi Hayati mengungkapkan ada perbedaan skor antara skor rata-rata sebelum dan sesudah siswa diberikan perlakuan. Nilai rata-rata pre-test adalah 63,21 dan nilai rata-rata post-test adalah 71,42. Kesimpulannya, efektif menggunakan teknik Trial Web Shifting dalam 
Pembelajaran Menulis pada Siswa Kelas X SMA Negeri Sumber Harta Tahun Pelajaran 2014/2015.

Penulis telah melakukan ketiga alternatif tehnik menulis teks sejarah islam menggunakan bahasa inggris selama pandemi covid-19 oleh mahasiswa yang penulis ajarkan dan hasilnya terjadi peningkatan kemampuan mahasiswa dalam menulis. Tehnik juga dapat dilakukan mix tehnik atau penggabungan tehnik yang digunakan sehingga hasil yang diperoleh lebih maksimal.

\section{Daftar Pustaka}

Beach, R., \& Marshall, J.D.(1991). Teaching Literature in the Secondary School. New York, NY: Harcourt Brace Jovanovich, Inc.

Bunyamin (2009).The Effectiveness of Using Dicstom Technique to Teach Narrative Writing to the Eleventh grade Students of MAN 2 Palembang.

Daniel, J. (2020). Education and COVID 19 Pandemic Era. Prospect Journal Number 49 (1), 91-96. Online: http.link.springer,com. Accessed on August 10, 2021.

Darwis, D. (2013). English for Islamic Studies. Handbook for IAIN for Islamic Research on Teaching. Jakarta: PT Raja Grafindo Persada.

Harmer, R. (2006). An Experiment with Dictogloss, MET Journal (online) 10 (3) Retrieved on May 23, 2017, from http://www.dictogloss-adaptation\%pdf.

Hayati, F. S. A. (2014) Using Trial Web Shifting Technique in Teaching Writing to the Tenth Grade Students of SMA Negeri Sumber Harta. An Unpublished Undergraduate Thesis. Lubuklinggau: STKIP-PGRI Lubuklinggau 
Huda, N. (1996). Language Learning and Teaching. Issues and Trends. Malang: Universitas Negeri Malang Publisher.

Lytovchenko, L. (2009). How to Make Upper;Level University English Classes More Interactive. English Teaching Forum, 47 (2):24-29

Novriyani, A. (2007). Using Engagement Strategy to Teach Writing to the Eleventh Grade Students of SMA Xaverius 1 Palembang. An Unpublished Undergraduate Thesis, Inderalaya: Sriwijaya University Palembang Press.

Tardy, C.M., \& Courney, J. (2008). Assignement and Activities in Teaching Academic Writing in Teaching Academic Writing. English Teaching Forum. 48 (2): 12-20. 


\title{
PERAN IBU TUNGGAL DALAM MENJAGA KETAHANAN KELUARGA PADA MASA PANDEMI
}

\author{
Khaerunnisa Tri Darmaningrum, M.Pd ${ }^{18}$ \\ IAIN Pekalongan
}

\begin{abstract}
"Peran ganda atau ibu tunggal kerap menjadi perkara yang berat untuk dilakukan, tetapi kehidupan harus tetap berjalan"
\end{abstract}

Pandemi covid-19 yang hingga saat ini masih menguasai kehidupan masyarakat dunia begitu pula di Indonesia. Hal ini menjadi tantangan tersendiri bagi perputaran perekonomian di Negara kita khusunya bagi keluarga menengah kebawah yang mengalami dampaknya secara langsung. Awal mula munculnya virus ini menjadikan banyak warga merasa was-was dan takut untuk keluar rumah karena takut tertular virus ini, hingga diberlakukannya peraturan pemerintah dengan adanya PSBB atau Pembatasan Sosial Berskala Besar. Dilakukannya pembatasan sosial menjadikan warga yang ingin keluar rumah harus mematuhi protokol kesehatan dengan menggunakan masker dan menjaga jarak antar satu dengan

18Penulis lahir di Pekalongan, 30 Juni 1988, penulis merupakan Dosen IAIN Pekalongan dalam bidang pemberdayaan masyarakat pada Fakultas Ushuluddin, Adab dan Dakwah. Penulis menyelesaikan gelar Sarjana Pendidikan Ilmu Pengetahuan Sosial di UIN Malang (2010), sedangkan gelar Magister Pendidikan Ilmu Pengetahuan Sosial diselesaikan di Universitas Negeri Semarang (2013). 
lainnya. Selain itu, warga juga mulai banyak diedukasi untuk melakukan cuci tangan menggunakan sabun atau dikenal dengan istilah Gerakan CTPS (cuci tangan pakai sabun). Penerapan protokol kesehatan secara ketat juga diberlakukan ketika kita berada dalam lingkungan keluarga. Hal ini tentu dimaksudkan agar tidak adanya penularan yang terjadi pada lingkungan keluarga.

Sebagaimana diketahui, penularan virus covid-19 ini sangat mudah hanya dengan terkena droplet dari orang yang sudah membawa virus ini. Pemerintah terus menerus menghimbau agar tidak ada cluster-cluster baru dalam penyebaran virus covid-19 dengan berbagai upaya. Sudah lebih dari satu tahun pandemi ini masih berada di bumi Indonesia dengan jumlah korban tertular baik hidup maupun meninggal semakin bertambah, hingga menjadikan pemerintah mencari upaya lain untuk pencegahan secara masif dan diberlakukanlah PPKM atau Pemberlakuan Pembatasan Kegiatan Masyarakat yang dimulai sejak awal tahun 2021 hingga saat ini memasuki level 4. Yang mana dengan adanya PPKM ini menjadikan ruang gerak masyarakat secara umun menjadi semakin terbatas. Sebagaimana artikel yang ada pada merdeka.com menjelaskan tentang dampak PPKM terhadap perekonomi sangat besar. Menurut direktur riset center of reform on economis (core) Piter Abdullah dalam merdeka.com menyatakan adanya konsekuensi yang harus dibayar jika penerapan PPKM diperpanjang lagi (Putra, 2021).

Upaya-upaya yang dilakukan pemerintah untuk mencegah penyebaran virus covid-19 selain dengan mengedukasi masyarakat dengan penerapan protokol kesehatan, juga dilakukan dengan merubah pola kehidupan secara umum di masyarakat dari berbagai bidang. Bidang 
Pendidikan yang sebelumnya dilakukan dengan pembelajaran secara langsung atau luring (luar jaringan), kemudian mulai dialihkan dengan pembelajaran online atau daring (dalam jaringan). Diawal tersebarnya virus ini, seluruh sekolah bahkan universitas melakukan pembelajaran jarak jauh. Semua pembelajaran, tugas dan sebagainya dilakukan secara online.

Tidak hanya pada bidang Pendidikan, pandemi ini juga memberikan dampak pada bidang pekerjaan baik sektor formal maupun informal. Di lingkungan pekerjaan formal sudah diterapkan dengan bekerja dari rumah atau Work From Home (WFH). Akan tetapi tidak begitu pada bidang informal, yang mana banyak yang mengalami PHK karena dampak pandemi ini. Dan masih banyak lagi dampak yang disebabkan dengan adanya pandemi ini dari berbagai sektor. Pandemi juga menimbulkan banyak konflik internal dalam keluarga. Munculnya konflik internal dipicu dari hilangnya pekerjaan dan sebagainya hingga muncul tren banyaknya perceraian yang ada di Indonesia. Perceraian yang terjadi akibat pandemi ini menjadikan berubahnya peran masing-masing anggota keluarga.

Peran individu dalam keluarga sudah mendapatkan takarannya masing-masing, baik peran sebagai orang tua dari sisi ayah atau ibu begitu pula peran individu sebagai seorang anak. Dalam kamus besar Bahasa Indonesia, keluarga diartikan sebagai satu kesatuan kekerabatan yang terdiri dari bapak, ibu dan anak-anaknya (Departemen Pendidikan dan Kebudayaan, 1966. Sedangkan dalam pandangan psikologi, keluarga merupakan perjanjian dua orang untuk hidup dan komitmen bersama berlandaskan adanya rasa cinta dan kasih sayang guna saling 
mempengaruhi walaupun dalam keragaman karena saling terkait dalam ikatan sedarah.

Begitu pula dalam kehidupan bermasyarakat, keluarga dikategorikan sebagai unit terkecil dalam struktur masyarakat yang menjalankan perannya masing-masing yang berdasarkan nilai dan norma yang berlaku dalam batasan masyarakat. Yang mana secara lazimnya peran lakilaki dan perempuan sebagai sepasang suami dan istri ini sudah menjadi satu pemahaman umum. Akan tetapi lain ceritanya jika dalam sebuah keluarga tidak memiliki kelengkapan anggota keluarga sebagaimana mestinya. Dimana ketika dalam keluarga ada susunan keluarga yang tidak dapat terpenuhi dengan berbagai alasan, semisal tidak adanya sosok ibu atau tidak adanya sosok ayah. Hal ini akan mempengaruhi perkembangan anggota keluarga lainnya baik secara langsung maupun tidak langsung. Seorang ibu yang menjadi single parent tentu memiliki kebutuhan yang berbeda dalam mempertahankan ketahan keluarganya yang terdiri dari dirinya dan anak-anaknya. Dalam menjalankan perannya seringkali mengalami ketimpangan karena adanya beban ganda yang harus diemban. Begitu pula dengan peran ibu tunggal dalam menjaga ketahanan keluarganya. Ibu tunggal selain mendapat stigma negatif seorang janda juga seringkali mengalami stereotype yang tidak menyenangkan dari masyarakat.

Sebagaimana penelitian yang dilakukan oleh Sulistyarini dkk menjelaskan tentang kemandirian dan sikap tangguh ibu tunggal sangat dibutuhkan untuk menjalankan peran ganda baik di sektor domestik dan di sektor publik. Yang mana dalam kebutuhan domestik ibu tunggal berperan untuk mencari nafkah dan memenuhi kebutuhan hidup dirinya dan keluarganya, disamping itu 
juga kebutuhannya untuk tetap bersosialisasi dengan masyarakat. Kondisi ibu yang harus mencari nafkah, membuat fokus dalam mengasuh anak menjadi terpecah. Ketidakberadaan suami mengakibatkan banyak masalah yang dihadapi oleh ibu sehingga berpengaruh terhadap keseharian keluarga dan komunikasi antar pribadi yang dilakukan antara ibu dengan anak-anaknya. Dikarenakan persoalan tersebut tidak jarang ibu melakukan kekerasan baik fisik maupun verbal kepada anaknya (Sulistyarini, dkk, 2020).

Beban ini terasa semakin berat terjadi pada saat pandemi, terutama bagi ibu tunggal yang mengalami dampak negatif secara langsung karena diberhentikan dari pekerjaannya. Tidak adanya anggota keluarga lain yang menjadi tempat berbagi menjadikan beban psikologis juga semakin bertumpuk disamping beban finansial. Berdasarkan hasil wawancara dengan salah satu ibu tunggal yang ada di lingkungan penulis, adanya kebutuhan lebih menjadi orang tua tunggal khususnya menjadi ibu tunggal menjadikan mereka memilih untuk melakukan pengasuhan terbaik kepada anak-anak mereka dan menjadi penopang kebutuhan ekonomi keluarga. Beban kerja pada karyawan wanita menjadi lebih besar karena selain bekerja, harus berperan juga menjadi ibu yang mendampingi anak menggantikan guru selama anak-anaknya belajar dari rumah. Bagi ibu yang bekerja pada sektor formal akan menjadi tantangan yang berat untuk dijalaninya karena harus dilakukan pada waktu yang bersamaan. Peran ganda yang dijalankan oleh ibu yang bekerja menjadikan konflik tersendiri baginya. Sehingga dapat berdampak pada fisik dan psikis ibu yang bekerja (Kusumastuti, 2020: 134-138). 
Peran dalam ketahanan rumah tangga sudah diatur dalam RUU Ketahan Keluarga yang terdiri atas 15 bab dan 146 pasal. Sebagaimana dalam pasal 25 menjelaskan tenhtang keajiban suami dan istri. Suami berkewajiban sebagai kepala rumah tangga, melindungi keluarga dari diskriminasi, melindungi diri dari penyimpangan seksual serta melindungi diri dari pelbagai masalah perjudian, pornografi dan seks bebas. Sedangkan kewajiban istri dalam pasal itu yaitu mengatururusan rumah tangga, keutuhan keluarga dan memperlakuakn suami dan anak secara baik serta memenuhi hak-hak suami dan anak dengan baik (Mudassir, 2021). Meskipun dalam pelaksanaannya pasal ini memperoleh banyak perbedaan pendapat, akan tetapi menjadi satu wacana yang apik ketika disandingkan dengan peran anggota keluarga dalam mempertahankan ketahanan keluarga. Hal ini berbanding terbalik jika dalam keluarga tidak ada sosok laki-laki atau yang disebut Suami atau Ayah menjadi nahkoda dalam menjaga ketahan keluarga. Oleh karenanya ibu tunggal pun kemudian mengambil alih peran ini.

Suatu masyarakat dikatakan mengalami perubahan sosial jika sistem sosialnya juga mengalami perubahan. Sebagaimana menurut Weber dalam buku Rekayasa Sosial karangan Jalaluddin Rakhmat menjelaskan tentang semua perubahan sosial dimulai dari perubahan tingkah laku manusia, perubahan dari human actions, perubahan dari tindakan-tindakan manusia di masyarakat (Jalaluddin, 2005). Hal ini pulalah yang terjadi pada ibu tunggal yang mengalami perubahan peran dan fungsinya sebagai anggota keluarga menjadi kepala keluarga. Tentu mengalami banyak perubahan yang diluar kendali bahkan seringkali mengorbankan diri sendiri guna menjaga ketahan keluarga. 
Dari sini dapat kita simpulkan peran ganda yang diemban seorang ibu tunggal tidak mudah apalagi berada pada masa pandemic covid-19 dengan berbagai ketentuann dan pembatasan-pebatasan yang dilakukan pemerintah sebagai upaya pencegahan penularan virus covid-19.

\section{Daftar Pustaka}

Departemen Pendidikan dan Kebudayaan.1996. Kamus Besar Bahasa Indonesia Edisi Kedua. Jakarta: Balai Pustaka

Kusumastuti, A.N. 2020. Dampak Konflik Peran Ganda Dimasa Pandemi Covid-19 pada Ibu Yang Bekerja. Retrieved from http://astri.staff.gunadarma.ac.id/Downloads/files/8 0041/ Patel, Harsh., Alkhawam, Hassan., Madanieh, Raef., Shah, Niel., Kosmas, Constantine E., and Vittorio, Timothy J. 2017. Aerobic vs anaerobic exercise training effects on the cardiovascular system. World Journal Cardiol. 2017 Feb 26; 9(2): 134-138. Doi: $10.4330 /$ wjc.v9.i2.134

Mudassir, Rayful. 2021. Pasal-pasal Kontroversial di RUU Ketahanan Keluarga. Bisnis.com (https://kabar24.bisnis.com/read/20200306/79/121 0112/pasal-pasal-kontroversial-di-ruu-ketahanankeluarga). diakses tanggal 20 Agustus 2021

Putra,D.A. 2021. Dampak Ekonomi Dipertaruhkan Jika PPKM Diperpanjang. Merdeka.com (https://www.merdeka.com/uang/dampak-ekonomidipertaruhkan-jika-ppkm-diperpanjang.html). diakses tanggal 20 Agustus 2021

Rakhmat, Jalaluddin. 2005. Rekayasa Sosial. Bandung: PT Remaja Rosda Karya

Sulistyarini, Indahria Rr., dkk. 2020. Pemberdayaan Ibu Tunggal Melalui Pelatihan Psikologis dan Pelatihan 
Pengembangan Produk Kerjasama dengan Yayasan Rumpun Nurani Program Komunitas Ibu Pilihan. Prosiding Seminar Nasional Hasil Penelitian dan Pengabdian Masyarakat dengan tema "Kesehatan Modern dan Tradisional". ISBN: 978-623-6572-15-3 


\title{
MEMBUMIKAN NALAR TEOLOGIS MASYARAKAT RELIGIUS DI ERA PANDEMI
}

\author{
Shinta Nurani, M.A ${ }^{19}$ \\ IAIN Pekalongan
}

"Ketentuan takdir memang sudah diatur oleh sang Pencipta, sebagai masyarakat religius dalam menghadapi masa pandemi hendaknya memiliki nalar teologis agar mampu memutus rantai penyebaran covid-19”

D unia internasional termasuk Indonesia saat ini tengah dilanda wabah penyakit yang disebut dengan pandemi Covid-19. Pada awalnya Covid-19 merupakan endemic virus yang muncul pada bulan Desember 2019 di Wuhan Cina. Virus ini tergolong sebagai virus yang berbahaya karena menyerang pernapasan dan penyebarannya begitu cepat, membuat keadaan dunia internasional melakukan perhatian penuh untuk menangani kasus ini, karena lambat laun kesehatan di seluruh penjuru dunia khususnya Indonesia semakin terpuruk akibat pandemic covid-19. Atas dasar itu, virus ini dikategorikan sebagai ancaman kesehatan dunia internasional. Hal ini didasarkan atas deklarasi WHO pada tanggal 30 Januari 2020 yang menyatakan bahwa pandemi

19Penulis lahir di Pekalongan, 1 Desember 1994. Penulis merupakan Dosen IAIN Pekalongan dalam bidang Ilmu Al-Qur'an dan Tafsir. Penulis menyelesaikan gelar Sarjana Ushuluddin pada Program Studi Tafsir Hadits di STAIN Pekalongan (2016), dan melanjutkan gelar Magister of Arts di UIN Sunan Kalijaga pada Program Studi Interdisciplinary Islamic Studies (2018). 
Covid-19 membuat kesehatan internasional berada dalam keadaan darurat (Wang, 2020: 2).

Berbicara dalam lingkup negara Indonesia yang sangat unik dengan berbagai keragaman di dalamnya baik agama, suku, bahasa, budaya, dan lainnya menjadikan negara Indonesia harus memiliki strategi yang berbeda dalam menghadapi era pandemi Covid-19. Salah satu fenomena yang menarik di Indonesia adalah kompleksitas masyarakat religius yang seringkali mempertentangkan dan membenturkan agama dengan negara. Pertentangan ini dilakukan oleh sebagian kelompok splinter Islam yang mengatasnamakan agama di atas segala-galanya dengan tendensi teologis yang menyatakan bahwa segala nasib, peristiwa dan kematian, sudah menjadi bagian takdir dari Allah SWT untuk makhluknya dan oknum splinter meyakini bahwa yang harus ditakuti hanyalah Allah SWT (Azra, 2020). Pernyataan seperti ini merupakan cara pandang yang simplitis dalam memandang agama yang justru tidak memahami esensi dari agama itu sendiri.

Islam sebagai sebuah agama mayoritas yang dianut oleh masyarakat religius di Indonesia menghadirkan versi agama yang rahmatan lil alamain untuk membawa misi nilai-nilai kemanusiaan yang lebih menentramkan bagi umatnya (Yuliyanto, 2008: 204), sebagaimana tawaran terbaik kepada umatnya dalam menghadapi wabah pandemi Covid-19. Dalam konteks Islam, agama telah menurunkan al-Quran dan hadits sebagai pedoman umat manusia dan sejarah Islam masa lalu sebagai pelajaran. Melalui al-Quran, hadits dan sejarah Islam itulah manusia diberi tugas untuk menggali bagaimana sikap yang diajarkan agama secara kontekstual dalam menghadapi wabah Covid-19 agar nalar teologis masyarakat religius di 
era pandemi dapat diimplementasikan dalam kehidupan sehari-hari.

Allah SWT telah mengajarkan kepada manusia agar selalu meminta perlindungan kepada-Nya dengan tetap tenang (QS. Yusuf[12]: 64). Selain itu juga ikhtiar sesuai dengan kebutuhannya (QS. Ar-Ra'd[13]: 11). Allah memberikan musibah kepada hamba-Nya agar selalu memperbaharui keimanannya (QS. At-Thaghabun[64]: 11). Ayat-ayat tersebut secara kontekstual memberikan pedoman bagi manusia agar tidak overpanic menghadapi pandemi dan tetap tenang dengan melakukan ikhtiar semaksimal mungkin yang kita bisa.

Dalam sebuah kisah juga dijelaskan, pada zaman Khalifah Umar ibnu Khattab, umat Islam dilanda dengan wabah Thaun yang menyebabkan sekitar 25.000 jiwa manusia meninggal di Syam akibat wabah tersebut. Bahkan seorang sahabat Nabi SAW yang bertugas sebagai gubernur Syam yakni Abu Ubaydah bin Jarrah juga meninggal dunia akibat wabah Thaun, sehingga kemudian digantikan oleh sahabat Muadz bin Jabal. Sepeninggal kepemimpinan Muadz bin Jabal dilanjutkan oleh sahabat Amr bin Ash. Kepemimpinan Amr bin Ash memunculkan aturan baru kepada umat Islam di Syam ketika itu. Amr bin Ash berkata kepada umatnya, "wabah itu seperti api dan kayu bakarnya ialah manusia, jika manusia tetap berkerumun, maka api akan terus menyala dan jika kayu terpisah, maka api akan meredam dengan sendirinya".

Pernyataan Amr bin Ash di atas kemudian menjadikan Amru bin Ash mengeluarkan kebijakan kepada masyarakat Syam agar melakukan uzlah di bukit-bukit. Selanjutnya, Negara memberi jaminan kepada siapapun yang tidak punya bekal atas uzlahnya tersebut, dengan tujuan untuk 
mendekatkan diri kepada Allah SWT. Setelah sekian bulan berlalu kemudian wabah Thaun tersebut menghilang di kota Syam dengan sendirinya (An-Nuwairi, 1997).

Penyataan di atas merupakan bukti bahwa Islam sejak dulu telah menjelaskan konsep physical distancing (lockdown) melalui sejarah peristiwa pada masa Umar bin Khattab dan Amr bin Ash di Syam (Nasution, 2020). Maka, sudah selayaknya langkah tersebut dijadikan sebagai pedoman oleh masyarakat terlebih umat Islam. Oleh karena itu, masyarakat religius di Indonesia dapat melakukan karantina mandiri (self isolation) dengan berdiam diri di rumah. Jikapun terpaksa harus keluar rumah, maka masyarakat harus menggunakan alat perlindungan mandiri, seperti masker, sarung tangan dan hand sanitizer atau sabun, serta selalu berdoa kepada Allah SWT agar terhindar dari wabah penyakit dan bala, selalu melakukan sedekah diniatkan untuk menangkal bala dan selalu berdzikir kepada Allah SWT pada setiap waktu, serta selalu menjaga kebersihan baik langsung cuci tangan sehabis bepergian, dan melakukan kebersihan-kebersihan diri lainnya.

Di sisi yang lain, dalam masalah teologi, agama juga sebenarnya tidak terlalu mempersulit umatnya. Hal ini sebagaimana penjelasan mufassir kontemporer Indonesia (Shihab, 2020), yang menjelaskan bahwa pandemi covid-19 merupakan sebuah peringatan dari Allah SWT agar umat manusia selalu taat dan patuh terhadap tuntunan agama. Salah satu tuntunan agama Islam ialah memelihara jiwa dan kesehatan. Ini karena hakikatnya Agama Islam mendahulukan kemanusiaan atas keberagamaan. Oleh karena itu tidak heran terdapat fatwa ulama yang memberikan keringanan (rukhsah) berkaitan dengan ibadah demi menjaga keselamatan jiwa manusia. Kita diuji untuk 
mengikuti tuntunan agama itu. Apabila terdapat perbedaan pendapat atas tuntunan agama itu, maka ikutilah tuntunan pemerintah (ulil amri) sebagai jalan yang menyelesaikan perbedaan pendapat. Islam mendahulukan kemanusiaan atas keberagamaan. Sehingga saat ini yang diperlukan adalah memelihara jiwa dan kesehatan kita dengan mengikuti tuntunan dari para medis dan ulil amri (pemerintah) serta berikhtiar, berdoa juga bertawakal kepada Allah.

Tuntutan pemerintah dalam konteks ini ialah anjuran untuk tetap di rumah dengan menjaga kesehatan dan menahan diri untuk keluar rumah dan mengunjungi keramaian selama 14 hari. Hal tersebut bertujuan untuk menghentikan penyebaran virus Covid-19. Secara ekplisit sebenarnya juga telah dijelaskan oleh Nabi SAW:

"Apabila kalian mendengar tentangnya (wabah penyakit) di sebuah tempat, maka janganlah kalian masuk ke dalamnya, dan bila kalian berada di dalamnya, maka janganlah kalian keluar daripadanya sebagai bentuk lari daripadanya". (HR. Bukhari)

Hadits ini menegaskan, bahwa pernyataan serta kebijakan yang dilakukan pemerintah dan para ulama di Indonesia merupakan bagian dari kontekstualisasi penjelasan Nabi SAW pada masa lampau yang hendak diterapkan untuk masyarakat pada masa kini guna menghadapi wabah pandemi Covid-19. Selain itu, upaya yang bisa dilakukan adalah dengan tetap tenang dan menyibukkan diri pada hal-hal yang positif seperti meningkatkan digital skill karena sekarang ini kita hidup di era 4.0 yang menggunakan dunia digital dan mengandalkan informasi serta teknologi untuk membantu manusia dalam menjalankan aktivitas sehari-hari. Diantara hal yang dapat 
dilakukan adalah dengan technopreneurship, yaitu mengkreasikan dan melakukan inovasi melalui teknologi yang telah kita punya untuk pengembangan usaha, misalnya aktif berjualan di platform bisnis online, membuat platform elektronik tertentu sesuai bidangnya yang dapat diakses oleh semua orang di berbagai penjuru dunia, dan lainnya

Diharapkan dengan adanya penjelasan-penjelasan dari sudut pandang teologi dan tokoh agamawan sebagai bagian dari penegasan bahwa agama telah menegaskan berbagai permasalahan yang dihadapi umatnya. Penjelasan tersebut baik melalui pernyataan perintah maupun beragam peristiwa masa lalu yang hendaknya dijadikan sebagai pelajaran untuk menghadapi peristiwa saat ini, dengan melihat kembali sumber ajaran Islam. Sikap-sikap yang dilakukan oleh kalangan splinter Islam tidak terlalu menjadi euforia di tengah-tengah kondisi yang masih belum stabil. Hal tersebut karena moral panic dari kalangan splinter Islam justru lahir dari kurangnya pengetahuan tentang ideal moral ayat al-Qur'an, hadits, maqasid al-syariah Islam dan sejarah ajaran Islam itu sendiri. Dengan demikian, masyarakat religius di era pandemi ini harus mendahulukan kemanusiaan atas keberagamaan dengan tetap menjauhi hal yang menyebabkan terinfeksi wabah, mematuhi protokol kesehatan, mengikuti kebijakan pemerintah selaku ulil amri, menjaga kesehatan, meningkatkan imunitas, menjauhkan pikiran dan perasaan buruk, positive thinking serta menguasai digital skill dan technopreneurship agar kehidupan di era pandemi sekaligus peradaban 4.0 menjadi harmonis menuju Sumber Daya Manusia yang unggul dan berkualitas. 


\section{Daftar Pustaka}

An-Nuwairi, Shihabudin Ahmad Abdul Wahab. 1997.

Nihayah al-Arab fil Funun al-Adab, (Beirut: Daarul Kutub).

Azra, Azyunardi. "Virus Corona, Splinter Agama", Republika, Kamis 26 Maret 2020.

Nasution, Khoiruddin "Saintifik-Spiritual Hadapi Covid-19", Kedaulatan Rakyat, Jumat, 3 April 2020.

Shihab, M. Quraish. "Virus Corona Melanda Dunia", lihat, http://youtu.be/RI8U9obwFlw, 2020.

Wang, Cuiyan, Riyu Pan, Xiaoyang Wan, Yilin Tan, Linkang $\mathrm{Xu}$, Cyrus S. Ho, and Roger C. H. "Immediate Psychological Responses and Associated Factors During the Initial Stage of the 2019 Coronavirus Disease (Covid-19) Epidemic among the General Population in China", International Journal of Environmental Research and Public Health, 2020, 17, 2.

Yuliyanto, Muchamad. "Peran Agama Serta Implementasi Komunikasi dan Manajemen Konflik dalam Kerusuhan Sosial di Losari Brebes Jawa Tengah". Komunika, 2, (2) (2008), 204-218. 


\title{
URGENSI KEAKTIFAN SISWA DALAM MEWUJUDKAN GENERASI YANG UNGGUL DI TENGAH PANDEMI COVID-19
}

\author{
Isatul Hasanah ${ }^{20}$ \\ Universitas Islam Negeri Sayyid Ali Rahmatullah \\ Tulungagung
}

"Keaktifan siswa merupakan hal penting yang perlu untuk ditekankan oleh setiap guru dalam mewujudkan generasi yang mampu bersaing dan mengimbangi segala bentuk perubahan"

W abah atau pandemi covid-19 yang disebabkan oleh virus corona sangat mengguncangkan isi dunia. Kesiagapan cepat yang diterapkan oleh pemerintah menjadi suatu keputusan yang sangat tepat. Menteri Pendidikan dan Kebudayaan Republik Indonesia mengeluarkan surat edaran tentang beralihnya sistem pembelajaran. Hal ini disebabkan Indonesia termasuk dalam masa darurat penyebaran covid-19. Dalam surat edaran tersebut mengamanatkan bahwa sistem pembelajaran sementara ini dilakukan dengan sistem online atau jarak jauh (Sri

20Penulis bernama Isatul Hasanah, lahir di Madura Bangkalan, 15 Juli 1997. Saat ini penulis tinggal di kabupaten tulungagung tepatnya didaerah Boyolangu. Penulis menempuh pendidikan pada jenjang perguruan tinggi di IAIN Tulungagung (2015-2019), mengambil jurusan pendidikan guru madrasah ibtidaiyah fakultas tarbiyah dan ilmu keguruan. Pada tahun ajaran 2019/2020 penulis melanjutkan pendidikan pascasarjana (S2) di IAIN Tulungagung dengan mengambil jurusan yang sama yaitu pendidikan guru madrasah ibtidaiyah (PGMI) hingga saat ini. 
Herwanto Dwi Hatmo, 2021). Adapun tujuan tersebut untuk memperkecil skala angka penyebaran virus covid-19. Dalam menerapkan sistem pembelajaran secara daring tentu diperlukan beberapa hal untuk mendukung pembelajaran tersebut. Salah satunya yaitu koneksi internet yang memadai serta kesiapan seorang guru dan siswa. Koneksi internet yang kurang memadai tentu akan berdampak pada kegiatan proses pembelajaran. Terutama kondisi saat ini, koneksi internet sangat dibutuhkan guna dalam memaksimalkan proses pembelajaran secara daring (Qoriawati, 2021). Tidak semua sekolah memiliki kemampuan serta kesiapan dalam melaksanakan pembelajaran secara daring. Sehingga diperlukan perencanaaan yang matang agar pembelajaran tetap efektif dan memperoleh hasil yang maksimal.

Guru dalam melaksanakan kegiatan proses belajar mengajar menerapkan 5 konsep dasar atau perencanaan dalam pembelajaran. Yaitu meliputi pendekatan, strategi, metode, teknik dan taktik (Stender, Brückmann, \& Neumann, 2017). Penggunaan konsep dasar tersebut betujuan untuk menyusun pembelajaran agar lebih terstruktur dan sesuai dengan konsep pembelajaran. Salah satu konsep dasar yang diterapkan oleh guru yaitu adanya penerapan model pembelajaran. Di mana pemilihan model pembelajaran yang tepat tentu akan berpengaruh terhadap motivasi belajar siswa. Namun di sisi lain faktor yang terpenting dalam pembelajaran yaitu seorang guru. Hal ini disebabkan adanya pemilihan model tentu didukung dengan adanya kreativitas seorang guru dalam mengkemas pembelajaran agar lebih menarik. Mengurangi rasa kejenuhan yang dialami oleh siswa merupakan faktor yang dapat menunjang proses pembelajaran agar lebih efektif. 
Terlebih kondisi saat ini sangat diperlukan pembelajaran yang mampu mengaktifkan siswa. Salah satunya yaitu dengan mengkonsep pembelajaran yang menarik.

Peningkatan mutu pendidikan merupakan suatu hal yang berkembang di era globalisasi ini. Sumber daya manusia memiliki peranan penting dalam proses peningkatan tersebut. Hal ini dapat dilihat dari adanya peningkatan yang dilakukan oleh setiap sekolah. Salah satu contohnya yaitu mencetak lulusan yang unggul dan mampu bersaing dengan sekolah lain. Tentu dari hal tersebut menjadi sebuah pertimbangan bagi pelaku pendidikan terutama bagi seorang guru. Yang hampir setiap hari berbaur dengan siswanya. Kenyamanan dalam mengikuti proses pembelajaran tentu akan berdampak pada semangat yang ditumbuhkan oleh siswa (Afifatu Rohmawati, 2015). Terlebih pandangan masyarakat saat ini beranggapan bahwa pembelajaran yang dilakukan secara daring kurang efektif. Siswapun merasakan kejenuhan saat mengikuti proses pembelajaran. Perlu kita ketahui tidak semua pembelajaran yang dilakukan secara daring menjenuhkan. Hal ini dapat kita lihat dengan tumbuhnya motivasi siswa dalam mengikuti proses pembelajaran. Secara tidak langsung meningkatnya kualitas pembelajaran salah satunya yaitu dipengaruhi dengan adanya ketertarikan siswa. Hal tersebut dapat menunjukkan bahwa konsep pembelajaran yang digunakan oleh seorang guru sesuai dengan apa yang dibutuhkan oleh siswa.

Kualitas pembelajaran yang efektif diperlukan untuk mendukung terciptanya pembelajaran yang aktif. Yang mana konsep pembelajaran saat ini lebih mengutamakan pada keaktifan siswa. Hal tersebut bertujuan agar pembelajaran tidak menjenuhkan serta ilmu yang didapat 
oleh siswa dapat diperoleh secara maksimal. Dalam kegiatan proses belajar mengajar tentu seorang guru terus berupaya mendesain pembelajaran agar lebih menarik. Baik dengan memanfaatkan teknologi maupun sarana dan prasana yang dimiliki oleh sekolah. Namun kebanyakan seorang guru lebih memanfaatkan sebuah media pembelajaran dalam mengaktifkan pembelajaran di kelas maupun di luar kelas. Seorang guru mengetahui bahwa pemanfaatan media dalam proses pembelajaran sangat memberikan dampak terhadap siswa. Terlebih pembelajaran yang dilakukan saat ini membutuhkan media sebagai alat yang dapat mengantarkan ilmu pengetahuan kepada siswa. Mengingat pentingnya ilmu pengetahuan bagi siswa, sehingga sekolah menjadi salah satu tempat dalam memperoleh ilmu serta mengembangkan ilmu pengetahuan.

Perencanaan pembelajaran yang disusun oleh guru tidak lain bertujuan untuk mengaktifkan siswa dalam proses pembelajaran (Kjell Rubenson, 2011). Meskipun pembelajaran yang dilakukan tidak semaksimal pembelajaran yang dilakukan secara tatap muka langsung. Namun seorang guru berupaya untuk terus menyusun strategi agar pembelajaran tetap efektif. Tercapainya tujuan pembelajaran yang maksimal salah satunya yaitu dapat menghidupkan suasana kelas menjadi aktif. Hal tersebut dapat dipengaruhi oleh beberapa faktor yang meliputi, adanya pemberian kuis dalam kegiatan pembelajaran, adanya umpan balik dari guru maupun siswa serta penggunaan metode yang tepat. Dalam hal ini pembelajaran akan lebih bermakna. Meskipun siswa hanya bertemu dengan guru dan temannya melalui media virtual. Namun di sisi lain siswa dapat menemukan hal yang baru. Kegiatan proses belajar yang dilakukan oleh siswapun tidak hanya 
berpacu pada penjelasan yang diberikan oleh guru. Melainkan seorang guru juga memberikan tugas kelompok secara virtual. Yaitu dengan melakukan kerja sama dalam menyelesaikan tugas. Misalnya membuat kesenian dan ketrampilan. Hal tersebut akan menumbuhkan rasa semangat siswa dalam mengikuti proses pembelajaran secara daring.

Pendidikan yang dilakukan di Indonesia saat ini memiliki tujuan yang pasti. Yaitu harus mampu meningkatkan ilmu pengetahuan serta menghasilkan generasi yang unggul. Sebutan generasi yang unggul artinya mampu menyesuaikan tuntutan yang ada di dunia dan apa yang dibutuhkan oleh masyarakat. Apalagi zaman saat ini dikenal dengan zaman modern. Artinya perkembangan ilmu teknologi dan komunikasi berkembang sangat pesat. Perkembangan tersebut dapat dimanfaatkan oleh seluruh masyarakat dalam mewujudkan tujuan yang hendak dicapai. Proses pembelajaran yang dilakukan di dalam kelas maupun di luar kelas tidak pernah terlepas dengan adanya seorang guru. Peran seorang guru sangat dibutuhkan. Meskipun pembelajaran saat ini dilakukan dengan sistem daring. Seorang guru berperan untuk bertanggung jawab dalam melaksanakan kegiatan pembelajaran. Hal ini disebabkan guru mempunyai pengaruh terhadap tujuan yang hendak dicapai oleh siswa. Misalnya adanya umpan balik yang diberikan oleh guru terhadap siswa. begitupun sebaliknya. Adanya partisipasi siswa dalam mengikuti proses pembelajaran dapat membantu seorang guru dalam mencapai tujuan yang telah ditetapkan. Sehingga lebih mudah bagi guru dalam mengembangkan ilmu pengetahuan yang dimiliki oleh siswa sebelumnya. 
Partisipasi aktif yang ditumbuhkan oleh siswa sangat berpengaruh terhadap proses perkembangan. Yaitu meliputi cara berfikir, mengontrol emosi, serta berperilaku dalam lingkup sosial. Seorang guru harus mampu mengembangkan keaktifan siswa dalam proses belajar. Meskipun pembelajaran saat ini tidak seperti pembelajaran yang dilakukan sebelumnya. Namun adanya perubahan sistem pembelajaran harus mampu memberikan kesan positif terhadap siswa. Ada beberapa hal yang perlu diperhatikan oleh seorang guru dalam menghidupkan suasana pembelajaran. Salah satunya yaitu meningkatkan daya minat siswa dengan cara memperbanyak melakukan interaksi dengan siswa. Diantara ciri pengajaran yang berhasil salah satunya yaitu dengan dilihat dari kadar kegiatan belajar mengajar. Semakin tinggi kegiatan belajar siswa semakin tinggi pula peluang berhasilnya sistem pengajaran. Berhubungan dengan keaktifan siswa tentu akan berdampak pada setiap generasi. Hal ini disebabkan pengaruh dari sistem pembelajaran cukup tertanam di benak siswa. Sehingga dalam hal ini seorang guru harus mampu menanamkan nilai-nilai yang positif. Keaktifan dalam proses pembelajaran tentu banyak ragamnya.mulai dari tumbuhnya minat, meningkatnya motivasi serta kemauan yang tinggi akan suatu hal yang baru. Namun di sisi lain adanya keaktifan yang dimunculkan siswa dapat melatih siswa dalam menghadapi perubahan zaman.

Mewujudkan generasi yang unggul pada era pandemi covid-19 menjadi proiritas yang utama. Terutama bagi peserta didik. Hal ini disebabkan dapat menjadi sebuah bekal bagi peserta didik dalam menghadapi perubahan yang ada. Perubahan yang terjadi saat ini tentu tidak dilihat dari kemampuan sumber daya manusia. Melainkan perubahan 
dapat terjadi kapan saja. Keaktifan belajar siswa merupakan unsur penting dalam proses pembelajaran. Siswa perlu terlibat aktif dalam aktivitas yang dirancang sebagai bentuk usaha belajar. Siswa bukan hanya sebagai pendengar saja melainkan juga harus ikut pertisipasi dalam menciptakan pembelajaran yang aktif. Salah satu faktor yang dapat mempengaruhi siswa menjadi aktif yaitu dengan adanya kenyamanan dalam proses pembelajaran. Secara tidak langsung cara mewujudkan generasi yang unggul salah satunya yaitu melalui pembelajaran. Hal tersebut disebabkan dalam proses pembelajaran terdapat banyak hal yang ditemui oleh siswa. Mulai dari menemukan ide baru serta mampu menerapkan dalam kehidupan sehari hari. Tanpa adanya suatu penerapan terhadap ilmu yang telah kita peroleh maka ilmu tersebut tidak akan memberikan manfaat bagi diri maupun orang lain. Sehingga diperlukan adanya suatu perubahan melalui ilmu yang telah di dapat dan dikembangkan. Bukan suatu hal yang sulit dalam mewujudkan generasi yang unggul di era revolusi industri saat ini. Akan tetapi merupakan suatu hal yang sangat mudah apabila seseorang benar-benar menginginkannya. Begitu pula sebaliknya. Sehingga banyaknya ilmu pengetahuan yang diperoleh menjadi sebuah solusi dalam mewujudkan generasi yang unggul.

\section{Daftar Pustaka}

Rohmawati, Afifatu. (2015). Efektivitas Pembelajaran. Jurnal Pendidikan Usia Dini, 9(1), 2015. https://doi.org/https://doi.org/10.21009/JPUD.09 1

Rubenson, Kjell. (2011). Adult Learning and Education. Unity States Of America: Academic Press. 
Qoriawati, U. (2021). Upaya Peningkatan Kualitas

Pembelajaran Daring bagi Peserta Didik MI/SD pada Masa Pandemi Covid-19. JEMARI (Jurnal Edukasi Madrasah Ibtidaiyah), 11(2), 115-122. https://doi.org/10.30599/jemari.v3i1.769

Hatmo, Dwi Hermanto Sri. (2021). Dampak Pandemi Covid19 Terhadap Efektivitas Pembelajaran Jarak Jauh Secara Daring. Scholaria: Jurnal Pendidikan Dan Kebudayaan, 11(2), 115-122.

Stender, A., Brückmann, M., \& Neumann, K. (2017). Transformation of topic-specific professional knowledge into personal pedagogical content knowledge through lesson planning. International Journal of Science Education. https://doi.org/10.1080/09500693.2017.1351645 


\section{BAB III \\ KEBIJAKAN DAN REGULASI SAAT PANDEMI}

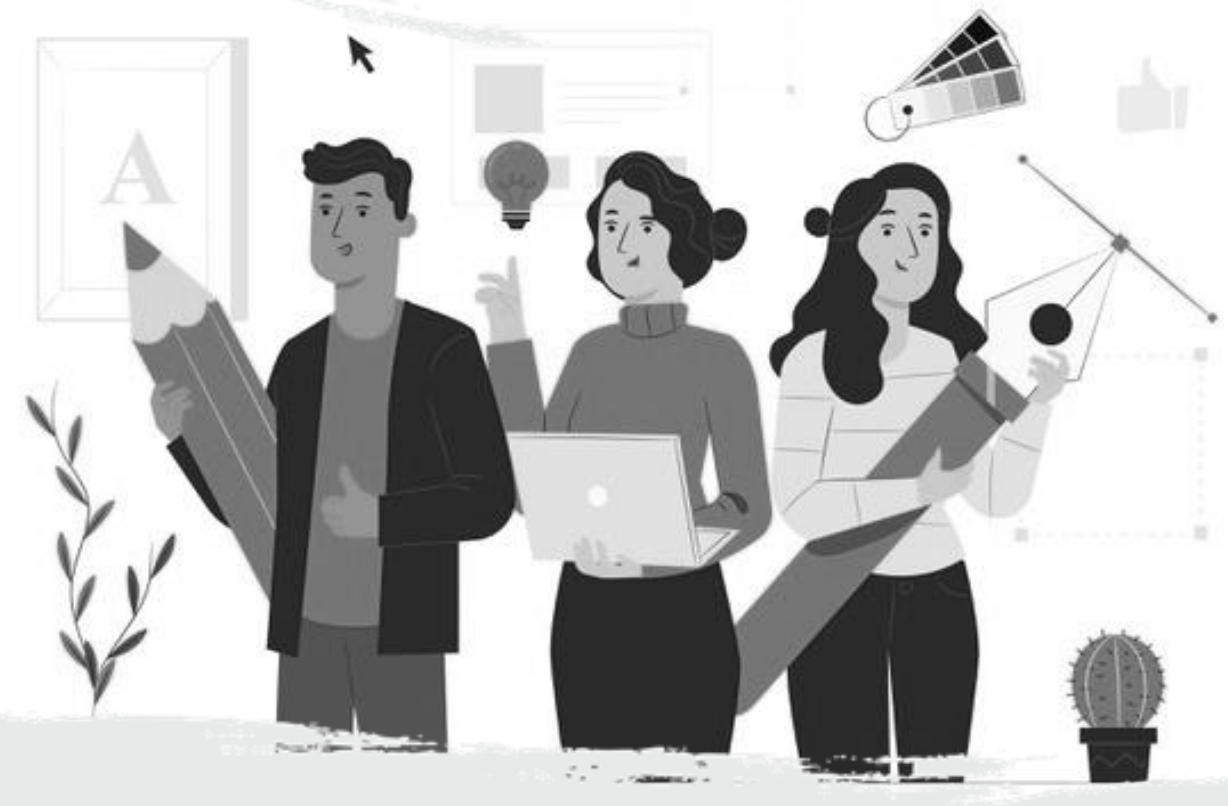




\title{
IMPLEMENTASI PERAN PEMERINTAH KOTA TEGAL TERHADAP KEBIJAKAN PERCEPATAN VAKSIN COVID-19
}

\author{
Citra Resmi Nanda Putri Pratiwi, S.H, M.H21 \\ Sekretariat Derah Kabupaten Brebes
}

"Mempercepat vaksin kepada seluruh masyarakat Kota Tegal merupakan bentuk peran pemerintah daerah dalam upaya penanggulangan Corona Virus Disease 2019”

Pemerintah Indonesia sedang memaksimalkan upaya percepatan vaksinasi covid-19 yang dilaksanakan di seluruh Kabupaten/Kota. Kebijakan berupa Peraturan Presiden Nomor 14 Tahun 2021 tentang Perubahan atas Peraturan Presiden Nomor 99 Tahun 2020 tentang Pengadaan Vaksin dan Pelaksanaan Vaksinasi Dalam Rangka Penanggulangan Pandemi Corona Virus Disease 2019 (Covid-19) menjadi dasar hukum pelaksanaan vaksinasi. Peraturan tersebut berisi tentang tanggung jawab pemerintah dalam melindungi masyarakatnya, pembagian tugas khususnya Kementerian Kesehatan dalam hal mendata dan menetapkan sasaran penerima vaksin covid19 di masing-masing wilayah serta pemberian saksi

21Penulis lahir di Tegal, 04 Desember 1995, penulis merupakan staf Subbag Bagian Hukum di Sekretariat Daerah Kabupaten Bebes, penulis mendapatkan gelar Sarjana Hukum Program Studi Hukum Keluarga Fakultas Syari'ah dan Hukum di UIN Walisongo Semarang pada tahun 2017 dan mendapatkan gelar Magister Hukum Program Studi Hukum Kenegaraan Fakultas Hukum di Universitas Jenderal Soedirman Purwokerto pada Tahun 2021. 
terhadap masyarakat yang menolak untuk divaksinasi. Seiring berjalannya waktu, Peraturan Presiden yang ada kemudian diubah kembali dengan Peraturan Presiden Nomor 50 Tahun 2021 tentang Perubahan Kedua atas Peraturan Presiden Nomor 99 Tahun 2020 tentang Pengadaan Vaksin dan Pelaksanaan Vaksinasi Dalam Rangka Penanggulangan Pandemi Corona Virus Disease 2019 (Covid-19).

Perubahannya terdapat pada pasal 11 A yaitu pengadaan vaksin dilakukan dengan memberikan tugas kepada badan usaha milik negara, baik penunjukan secara langsung pada badan usaha penyedia, atau kerjasama lembaga/badan internasional yang penyedianya mempersyaratkan adanya pengambilalih tanggung jawab hukum, Pemerintah bertanggung jawab untuk mengambilalih tanggung jawab hukum dalam menyediakan vaksin covid- 19 seperti keamanan (safety), mutu (quality), dan pengambilalihan tanggung jawab hukum oleh Pemerintah terhadap penyedia vaksin covid-19 sebagaimana dimaksud pada ayat (1) dilakukan selama waktu penyediaan, kemudian produsen telah melakukan sertifikasi berupa pembuatan obat yang baik dari lembaga yang berwenang di negara asalnya dan vaksin covid-19 yang telah disetujui penggunaannya oleh Badan Pengawas Obat dan Makanan. Kota Tegal termasuk salah satu kota yang sangat tanggap dalam pelaksanaan peraturan percepatan vaksinasi covid-19 dengan memberikan pelayanan khusus kepada masyarakat yang akan melakukan vaksinasi. Apabila ada masyarakat yang tidak mau disuntik vaksin maka akan mendapatkan sanksi administratif sesuai dengan Pasal 13 A Peraturan Presiden Nomor 14 Tahun 2021 berupa penundaan atau penghentian pemberian jaminan sosial atau 
bantuan sosial; penundaan atau penghentian layanan administrasi pemerintahan; dan/atau denda. Penerapannya sudah diberlakukan di beberapa kantor pemerintahan, swasta maupun tempat hiburan seperti Kecamatan, Kelurahan, Bank dan Pusat perbelanjaan.

Kebijakan tersebut diterapkan sebagai bentuk tanggung jawab dan peran aktif pemerintah Kota Tegal dalam melaksanakan program vaksinasi dan mengurangi penyebaran covid-19. Setiap satu minggu sekali Kecamatan dan Kelurahan mengadakan rapat evaluasi di Balaikota Tegal bersama dengan Walikota Tegal. Selama pencapaiannya belum maksimal maka pemerintah daerah akan terus mengawasi dan mendorong tenaga medis dan Kecamatan beserta Kelurahan untuk melakukan pendataan dan sosialisasi kepada setiap rukun tetangga maupun rukun warga untuk ikut berpartisipasi dalam program 1000 gerai vaksin covid-19 di Kota Tegal. Lokasi vaksinasi terletak di Rumah Sakit, Puskesmas, Klinik, Kantor Kecamatan, Kantor Kelurahan, Sekolah Dasar Negeri dan Swasta, Sekolah Menengah Pertama Negeri dan Swasta, Sekolah Menengah Kejuruan Negeri dan Swasta, Perguruan Tinggi, Mall, Pasar dan Gedung Lawang Satus Taman Pancasila. Sejak pelaksanaannya pada awal bulan agustus sampai dengan satu pekan, pencapaian vaksinasi yang semula 47 persen meningkat sekitar 57,10 persen. Jumlah masyarakat yang sudah divaksin sebanyak 121.648 orang. Akan tetapi Kota Tegal sempat kehabisan stok vaksin jenis Sinovac untuk pemberian dosis kedua. Sehingga untuk sementara masyarakat yang akan melakukan vaksinasi pada dosis pertama menggunakan jenis Astrazeneca (Fajar Bahruddin Achmad, 2021). 
Meskipun pencapaiannya tetap belum maksimal tetapi pelaksanaan program tersebut masih berjalan sampai dengan bulan Oktober 2021. Pemberian vaksin tidak hanya untuk masyarakat Kota Tegal, tetapi juga untuk masyarakat Kabupaten Brebes, Kabupaten Tegal dan Kabupaten Pemalang yang bekerja di Kota Tegal dengan ketentuan yang berlaku. Pada minggu terakhir bulan Agustus 2021 Kota Tegal mulai kehabisan stok untuk vaksin dosis pertama dan kedua sehingga untuk sementara waktu masyarakat yang belum melaksanakan vaksinasi tahap pertama bisa menggunakan vaksin jenis Astrazeneca dan menunggu untuk melaksanakan vaksin tahap ke dua jenis Sinovac. Permintaan penambahan vaksin terus diupayakan agar masyarakat dapat vaksin tanpa khawatir kehabisan stok vaksin yang semakin terbatas. Tenaga medis dan penyuluh vaksin juga disebar dan ditugaskan secara khusus ke tingkat Kecamatan/ Kelurahan untuk mengajak masyarakat yang menolak vaksin agar mau untuk divaksin.

Peran pemerintah Kota Tegal merupakan wujud dari tanggung jawab terhadap kesejahteraan masyarakatnya. Pemerintah ikut serta dalam kehidupan ekonomi dan sosial masyarakat termasuk yang berkaitan dengan keselamatan nyawa masyarakat akibat penyebaran wabah penyakit. Menurut Jeremy Bentham, pemerintah memiliki tanggung jawab untuk menjamin kebahagiaan yang sebesar-besarnya untuk masyarakat (Oman Sukmana, 2018). Pengaruh dari welfare state untuk mempermudah pemerintah dalam membangun kesejahteraan sosial yang terencana, melembaga, berkesinambungan dan menjamin masyarakat agar mendapatkan standar hidup yang layak termasuk jaminan kesehatan. Perwujudan kesejahteraan sosial masuk dalam konsep otonomi daerah dalam melaksanakan 
Pemerintahan Negara Kesatuan dalam menjalankan tugas dari pemerintah pusat. Menurut Joeniarto dalam Negara kesatuan seluruh urusan Negara sepenuhnya menjadi kewenangan dari pemerintah pusat dan apabila Negara tersebut menggunakan asas desentralisasi di daerah yang dibentuk oleh pemerintah lokal dengan hak mengatur dan mengurus rumah tangganya sendiri (Titik Tri Wulantutik, 2006: 1). Sehingga Walikota Tegal mengambil langkah yang tepat dalam membantu pemerintah pusat menekan jumlah penyebaran dan kematian akibat pandemi covid-19. Pada Pasal 12 Undang-Undang Nomor 23 Tahun 2014 tentang Pemerintahan Daerah bahwa kewenangan pemerintah yang bersifat wajib yaitu berkaitan dengan pelayanan dasar seperti pendidikan, kesehatan, sosial dan lain-lain. Tindakan pemerintah terkait vaksinasi merupakan konsekuensi logis dari kedudukan pemerintah sebagai suatu subyek hukum sehingga menimbulkan akibat hukum yang bersifat mengikat untuk seluruh masyarakat tanpa terkecuali termasuk masyarakat Kota Tegal untuk mengakses pelayanan publik.

Menurut Bruce J. Cohen, Peran atau role salah satunya yaitu peran nyata (Anacted Role) yang merupakan cara yang benar-benar dijalankan oleh seseorang dalam melakukan perannya (Supriyatna, Bambang Ali Kusumo, 2016). Kepala daerah berperan dalam menentukan keberhasilan suatu pemerintahan karena berkaitan dengan perannya dalam melaksanakan hak dan kewajibannya sesuai dengan kedudukan dan wewenang yang dimilikinya. Sedangkan menurut Hasan Shadhily, wewenang (authority) yaitu hak atau kekuasaan dalam memberikan perintah ataupun tindakan untuk mempengaruhi orang lain agar sesuai dengan tindakan yang diingunkan (Tim Penyusun Kamus, 
2012: 117). Walikota Tegal sesuai dengan wewenangnya memfasilitasi masyarakat Kota Tegal untuk menjalankan kewajibannya sebagai warga Negara untuk tunduk pada hukum yang berlaku untuk kepentingan dan keselamatan bersama. Masih banyaknya masyarakat yang belum sadar hukum untuk melaksanakan vaksin covid-19 membutuhkan perhatian khusus dari pemerintah Kota Tegal. Perlu adanya pendekatan persuasif untuk menarik minat masyarakat agar mau divaksin sehingga proses administrasi publik dan penyaluran bantuan khusus masyarakat yang kurang mampu dapat berjalan maksimal. Jika Pemerintah tidak segera bertindak cepat dapat menghambat pelaksanaan pemberian bantuan dan pelayanan yang membutuhkan tindakan cepat seperti pembuatan akta lahir, pengurusan KTP, SIM, Perbankan maupun bantuan PKH.

\section{Daftar Pustaka}

Ali Kusumo, Supriyatna dan Bambang. 2016. Pendayagunaan Peran Penasihat Hukum Dalam Penyelesaian Perkara Pidana. Jurnal EKSPLORASI. Volume XXIX Nomor 1.

Sukmana, Oman. 2016. Konsep dan Desain Negara Kesejahteraan (Welfare State), Jurnal Sospol, Volume 2, Nomor 1, Juli-Desember 2016.

Tim Penyusun Kamus-Pusat Pembinaan dan Pengembangan Bahasa. 2012. Kamus Besar Bahasa Indonesia. Jakarta, Balai Pustaka.

Wulantutik, Titik Tri. 2006. Pokok-Pokok Hukum Tata Negara. Cetakan Satu, Jakarta: Prestasi Pustaka.

Achmad, Fajar Bahruddin. Capaian Vaksinasi di Kota Tegal dalam Seminggu Terakhir Naik 10 Persen. https://pantura.tribunnews.com/2021/08/09/capa ian-vaksinasi-di-kota-tegal-dalam-seminggu- 
terakhir-naik-10-persen. Diakses pada tanggal 29 Agustus 2021, Pukul 20.00 WIB.

Undang-Undang Nomor 23 Tahun 2014 tentang Pemerintahan Daerah.

Peraturan Presiden Nomor 14 Tahun 2021 tentang

Perubahan atas Peraturan Presiden Nomor 99

Tahun 2020 tentang Pengadaan Vaksin dan Pelaksanaan Vaksinasi Dalam Rangka

Penanggulangan Pandemi Corona Virus Disease 2019 (Covid-19).

Peraturan Presiden Nomor 50 Tahun 2021 tentang Perubahan Kedua atas Peraturan Presiden Nomor 99 Tahun 2020 tentang Pengadaan Vaksin dan Pelaksanaan Vaksinasi Dalam Rangka Penanggulangan Pandemi Corona Virus Disease 2019 (Covid-19). 


\title{
POLITICAL WILL UNTUK MEMBANGUN MANUSIA UNGGUL MELALUI UU CIPTA KERJA SAAT PANDEMI
}

\author{
Ahmad Said, S.H ${ }^{22}$ \\ Bawaslu Kab. Demak
}

"Adanya kemauan politik dari pemerintah atau pengambil kebijakan melalui undang-undang cipta kerja untuk membangun sumber daya manusia unggul, berintegritas, dan berdaya saing di masa pandemi"

$\mathrm{M}$ asih teringat dibenak penulis saat Presiden Joko Widodo menyampaikan pidato atas Rancangan Undang-Undang Anggaran Pendapatan Belanja Negara (RUU APBN) Tahun Anggaran 2022 beserta Nota Keuangan di rapat paripurna DPR RI pada Rabu, 16 Agustus 2021. Presiden menyinggung telah menerbitkan UU Cipta Kerja dan akan fokus disalah satu poin yaitu memperkuat agenda SDM yang unggul, berintegritas dan berdaya saing, selain aspek lainnya yakni melanjutkan upaya pengendalian Covid-19, menjaga program perlindungan sosial, melanjutkan infrastruktur, memperkuat desentralisasi fiskal, reformasi anggaran agar belanja lebih efisien.

22Penulis lahir di Demak, 30 Agustus 1993, penulis dari sekretariat Badan Pengawas Pemilihan Umum (Bawaslu) Kabupaten Demak, Provinsi Jawa Tengah membidangi Divisi Hukum, Humas, Data dan Informasi, penulis menyelesaikan sarjana Ilmu Hukum di Fakultas Hukum Universitas Negeri Semarang. 
Terbesit pertanyaan, bagaimana kebijakan pemerintah dalam mambangun manusia unggul melalui UU Cipta kerja? Berkali-kali penulis mendengar dan melihat pada platform media sosial, koran dan televisi, pemerintah menyatakan setelah menata infrastruktur akan melakukan pengembangan dibidang sumber daya manusia (SDM).

Pemerintah dalam mengambil peran memiliki kemauan politik (political will) yang kuat, terlihat dari sisi politik hukum saat pandemi Covid-19 melanda Indonesia tepatnya pada pertengahan Maret 2020 lalu, sejumlah regulasi sedang digodok untuk menjawab tantangan Indonesia ke depan. Kebijakan itu tidak lepas dari tindakan pemerintah yang salah satunya mengeluarkan peraturan (regeling) kemudian mengusulkan kepada DPR dalam prolegnas untuk membahas RUU Cipta kerja. Setelah melalui berbagai proses termasuk pembahasan, persetujuan dan pengesahan antara Pemerintah dan DPR, telah lahir pada 2 November 2020 UU No. 11/2020 Tentang Ciptaker. Dalam kajian ilmu politik, UU/hukum merupakan produk dari politik, sehingga pemerintah mengambil kebijakan dengan menggunakan instrumen politik hukum dalam merencanakan kebijakan. Dengan demikian adanya payung hukum tersebut berfungsi sebagai rekayasa dan kontrol sosial. Pertama, kebijakan negara tentang hukum yang akan diberlakukan dan tidak diberlakukan. Kedua, historis dari kemauan politik baik secara ekonomi, sosial dan budaya atas realitas gejolak di masyarakat. Ketiga, penegakan hukum dalam implemantasi di lapangan, (Mahfud MD, 2014:4).

Pemerintah dan DPR sebagai pejabat administrasi negara, maka segala kewenangan untuk mengatur warga dan negara harus menggunakan hukum, karena segala tindakan organ pemerintah berdasarkan hukum, bukan 
berdasarkan kekuasaan atau penyalahgunaan kewenangan. Melalui Pemilu, masyarakat luas telah menitipkan kepada konstituennya di lembaga eksekutif dan legislatif untuk menjalankan roda penyelenggaraan negara agar mampu mewujudkan negara kesejahteraan (walfare state) sebagaimana teori hukum administrasi negara. Sehingga melalui progam-program pemerintah diharapkan dapat membangun sumber daya manusia, misalnya disektor pengembangan ilmu pendidikan, perlindungan dan kesejahteraan buruh, pemberdayaan, perlindungan UMKM dan Koperasi, kemudahan berusaha serta mendorong pertumbuhan investasi.

Sejalan hal tersebut, meski pro dan kontra tentang adanya UU Ciptaker, Pemerintah dan DPR akhirnya mengesahkan menjadi UU. Berdasarkan sumber dari temuan Survei Indometer menunjukkan 90,1\% setuju atas adanya Omnibus Law Ciptaker. Namun terdapat 8,6\% menolak dan sisanya tidak tahu/tidak menjawab sebasar 1,3\%. Diketahui Omnibus Law UU Ciptaker ini untuk menyederhanakan regulasi agar mempermudah perizinan dan memulihkan perekonomian nasional, kemudian mendorong iklim investasi sehingga mampu mengembangkan SDM unngul. Dalam konteks itu, tentunya akan berimplikasi pada sisi sumber daya manusia.

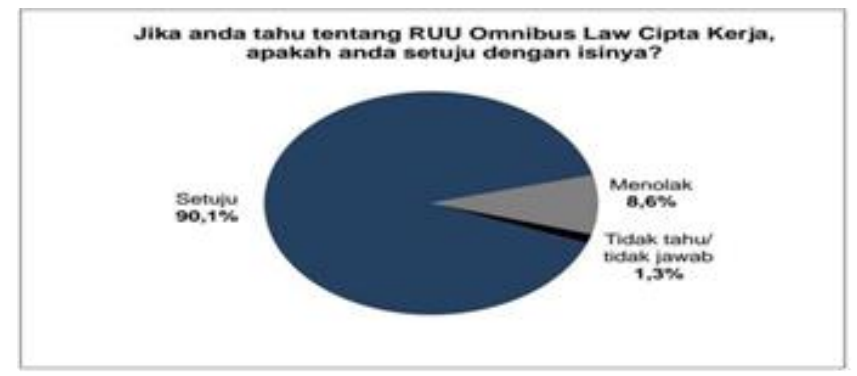

Gambar 1. Diagram lingkaran tentang adanya RUU Cipta Kerja 
Namun sisi lain, Indonesia masih dilanda pandemi Covid-19, sehingga adanya instrument politik hukum melalui UU Cipta Kerja akan memperbanyak lapangan kerja untuk menjamin perlindungan dan kepastian hukum diberbagai bidang. Selain itu, saat ini masyarakat dituntut untuk menyesuaikan diri hingga menjadi manusia yang adaptif menghadapi gelombang yang semakin kompetitif ditengah tuntutan globalisasi ekonomi. Kajian atas bidangbidang untuk membangun SDM unggul sebagai berikut:

\section{Bidang Ketenagakerjaan}

Bidang ketenagakerjaan teletak di Bab IV. Pasal 13 ayat (1) menyatakan pelatihan bagi tenaga kerja diselenggarakan oleh lembaga pelatihan dari pemerintah, swasta, perusahaan dan di tempat pelatihan atau tempat kerja. Secara normatif menegaskan bahwa upaya meningkatkan kompetensi melalui berbagai palatihan di dunia kerja yang semakin kompetitif tentunya tenaga kerja harus dibekali tentang pelatihan oleh pemerintah atau pemberi kerja. Sebagai contoh, sekarang banyak disiplin ilmu bekerja yang tidak sesuai rumpun ilmunya. Seseorang harus mampu disegala bidang, termasuk memanfaatkan teknologi sebagai menambah penghasilan. Dalam konteks SDM unggul, kebijakan pembentuk UU bermaksud memberikan dampak positif untuk memberikan keterampilan soft skill/hard skill bagi tenaga kerja. Lebih dari itu, dalam Pasal 42 ayat (2) melarang tenaga kerja asing untuk menduduki jabatan personalia. Artinya, bahwa WNA yang memiliki kompetensi tidak mungkin akan bisa menduduki jabatan tersebut, kecuali orang Indonesia asli. Dari sisi ini norma yang mengatur itu telah memberikan ruang sebanyak-banyaknya untuk 
memperluas tenaga kerja bagi warga Indonesia. Sementara setiap lembaga pelatihan harus memiliki ijin, hal ini pun memberikan kemudahan dalam perizinan siapa saja yang akan membentuk lembaga pelatihan, sehingga muncul wirausaha baru saat pandemi Covid19.

\section{Bidang pemberdayaan UMKM dan Koperasi}

Sejumlah pasal dalam UU Ciptaker merubah pasal yang ada dalam UU Koperasi. Pasal ini terletak pada Bab $\mathrm{V}$, tentang kemudahan UMKM dan Koperasi. Misalnya sebelum dirubah dalam pendirian koperasi berjumlah 20 orang. Namun pasca adanya UU Ciptaker menjadi 3 orang. Hal ini memberikan angin segar yang ingin mendirikan koperasi karena dipermudah syarat anggota. Harapannya melahirkan koperasi-koperasi yang bisa mendorong ekomoni rakyat, sehingga mampu menciptakan lapangan kerja baru.

Sementara, ijin UMKM juga dipermudah dengan perizinan terintegrasi melalui oss (Online Single Submission) secara elektronik. Misalnya, pedagang krupuk, home industry, pelayanan jasa, dosen dan guru les privat pun bisa membuat Nomor Induk Berusaha (NIB). Dengan adanya NIB bisa digunakan untuk kepentingan administrasi dalam pemerintahan. Berdasarkan data dari menteri Koperasi dan UKM menunjukkan tenaga kerja enam puluh dua juta atau sembilan puluh sembilan persen usaha di Indonesia adalah UMKM, sedangkan Koperasi sebesar sembilan puluh tujuh persen, (NA UU Ciptker, 2020:210). Dari materi muatan klaster dalam UU Ciptaker di atas, sejatinya political will dari pemerintah ingin mendorong UMKM melalui kesempatan membuka usaha baru dan 
mengembangan pelatihan bagi tenaga kerja baik sesudah ataupun saat pandemi Covid-19. Dengan demikian, dapat disimpulkan bahwa UU Ciptaker ini disahkan untuk mempermudah aspek legalitas izin usaha guna memperoleh penghasilan dan UU Ciptaker ini diharapkan juga akan mampu mengembangkan kualitas sumber daya manuasia (ketenagakerjaan) unggul di Indonesia.

\section{Daftar Pustaka}

MD, Mahfud, Moh. 2014. Politik Hukum di Indonesia, Jakarta: Rajawali Pers

Naskah Akademik RUU Nomor 11 Tahun 2020 tentang Cipta Kerja

https://www.beritasatu.com/nasional/687947/surveiindometer-901-persen-setuju-ruu-omnibus-law di akses 22 Agustus 2021 


\title{
ANALISIS FENOMENA PEMBELAJARAN DARING MELALUI KEBIJAKAN PENDIDIKAN PADA MASA DARURAT PENYEBARAN CORONA VIRUS DISEASE (COVID 19)
}

\author{
Apriya Maharani Rustandi, S.Pd 23 \\ Universitas Pendidikan Indonesia
}

"Penyebaran corona virus disease (covid 19) menimbulkan banyak perubahan di berbagai aspek, salah satunya adalah pendidikan. Kebijakan untuk melakukan pembelajaran jarak jauh perlu adanya analisis untuk mempertahankan nilai-nilai pendidikan"

\section{Pendahuluan}

A manat dari konstitusi pada alenia ke empat yakni mencerdaskan kehidupan bangsa, dengan adanya amanat konstitusi yang seperti itu sudah selayaknya pemerintah menjalankan tujuan dari Negara Kesatuan Republik Indonesia. Pada bidang pendidikan, tujuan dari pendidikan nasional tercantum pada Undang-undang Nomor 20 Tahun 2003 "Berkembangnya potensi peserta didik agar menjadi manusia yang beriman dan bertakwa kepada Tuhan Yang Maha Esa, berakhlak mulia, sehat, berilmu, cakap, kreatif, mandiri, dan menjadi warga negara

23Penulis lahir di Batam, 28 April 1998, penulis merupakan Mahasiswa Pasca di Universitas Pendidikan Indonesia dalam bidang Pendidikan Kewarganegaraan, penulis menyelesaikan gelar Sarjana Pendidikan di Universitas Pendidikan Indonesia (2021). 
yang demokratis serta bertanggung jawab". Salah satu cara yang dapat dilakukan oleh pemerintah dalam mewujudkan tujuan dari mencerdaskan kehidupan bangsa ialah adanya tri pusat pendidikan yang diusung oleh Ki Hajar Dewantara.

Perwujudan dari tri pusat pendidikan dapat dilaksanakan melalui kebijakan pendidikan nasional, namun sudah dua tahun terakhir kita semua mengalami pandemi yang belum kunjung selesai sehingga pemerintah mengeluarkan kebijakan mengenai pendidikan, salah satunya ialah dengan penghapusan Ujian Nasional pada masa pandemic, belajar dan mengajar di rumah melalui daring, program belajar via TVRI dan pemberian dana untuk internet. Kebijakan tersebut dikeluarkan seiring dengan mewabahnya virus covid-19. Namun tidak semua kebijakan dapat memuaskan semua pihak dan tidak semua kebijakan dapat menjawab problematika secara keseluruhan (Supardi, 2012).

\section{Pembahasan}

\section{Problematika Pendidikan di Masa Pandemi Covid-19}

Perwujudan suatu pendidikan yang dapat mewujudukan kualitas dan keadilan tentu tidak mudah karena fakta dilapangan dapat kita temui beberapa persoalan pendidikan yakni dengan kondisi geografis Indonesia dan bentuk wilayah kepulauan, disatu sisi merupakan sebuah anugrah bagi Indonesia, disisi lain menjadi sebuah hambatan dan kesenjangan antara kota dan wilayah pedesaan, perkotaan memiliki fasilitas lengkap dan akses yang cukup untuk mengenyam bangku pendidikan sedangkan daerah terpencil akses 
dari pendidikan yang sangat memprihatinkan karena peserta didik yang tinggal di desa lahir dari keterbatasan dan terisolasi dengan akses informasi dan komunikasi (Santosa, 2020; Vito \& Krisnani, 2015).

Sebuah kegiatan pembelajaran sering kali membuat para peserta didik jenuh dikarenakan pembelajaran yang cenderung satu arah, sehingga pada sistem pembelajaran online ini orang tua siswa harus mempunyai perhatian ekstra dalam membuat sebuah formula yang tepat untuk pendampingan bimbingan akademik pada masa pembelajaran online. Tidak hadirnya sosok guru secara nyata pada keadaan nonvirtual membuat peserta didik merasa jenuh dengan proses pembelajaran. Menurut (Pawicara \& Conilie, 2020) mengemukakan bahwa kebosanan tersebut dapat muncul selain karena minimnya peranan dari orang tua juga ketidakmampuan peserta didik dalam mencerna sebuah informasi dari guru dan tidak ada tempat untuk bertanya.

Suasana dalam rumah juga sangat mempengaruhi kondisi psikis seorang anak sehingga dengan itu keluarga harus mampu menciptakan kondisi yang nyaman bagi peserta didik, karena keluarga mempunyai peran sebagai faktor pertama dan utama dalam mempengaruhi perilaku anak dan remaja, salah satu cara yang dapat dilakukan yakni dengan merubah suasana rumah menjadi suasana sekolah. Menurut (Benyamin, 2020) keluarga memiliki fungsi Edukatif (Pendidikan) yakni keluarga merupakan lingkungan pendidikan pertama dan utama bagi anak.

Pemanfataan buku teks yang menjadi sumber bahan belajar peserta didik menjadi suatu hal yang mutlak 
ketika pembelajaraan secara online. Menurut (Setyawan \& Wijayanti, 2020) buku ajar selama ini dimanfaatkan sebagai sumber utama dalam kegiatan belajar mengajar. Ketika pembelajaran menjadi online, maka akses untuk peserta didik memperoleh buku menjadi lebih terbatas dan mengandalkan media internet saja, berbeda halnya ketika peserta didik melaksanakan pembelajaran secara offline maka buku-buku dalam bentuk cetak dapat dengan mudah ditemukan di perpustakaan sekolah.

\section{Analisis Kelebihan dan Kekurangan dari Pendidikan Jarak Jauh}

Kelebihan pada sistem pembelajaran jarak jauh dapat dilihat dengan adanya kegiatan belajar mengajar yang lebih santai, karena kegiatan tersebut dilaksanakan secara online. Suasana yang tercipta pada saat pembelajaran daring menjadi lebih fleksibel menggunakan media yang ada seperti alat untuk conference meeting. Kelebihan dari pembelajaran online dapat melatih peserta didik untuk memahami teknologi dalam pembelajaran digital. Pengurangan penggunaan kertas, menjadi salah satu kelebihan dari pembelajaran online, karena tugas yang sudah dibuat tidak perlu diprint cukup dikirimkan dalam bentuk softfile kepada guru yang bersangkutan pada mata pelajaran tersebut, hal ini dapat mendukung gerakan dari paperless. Kebiasaan baru yang timbul setelah adanya kegiatan menonton film dan menganalisis atau saran untuk berolahraga membuat peserta didik mempunyai sering melakukannya yang nantinya akan menjadi sebuah bentuk atau pola kebiasaan baru.

Kekurangan dari sistem Pembelajaran Jarak Jauh yakni tidak jauh berbeda dengan adanya problematika 
yang ada pada pembelajaran online, mulai dari kurangnya motivasi belajar dikarenakan tidak adanya sosok guru yang nyata hadir dihadapan para peserta didik dan akibatnya berdasarkan penelitian yang dilakukan oleh (Dewi, 2020) peserta didik kebanyakan hanya mencari aman dalam mengerjakan tugas saja. Peserta didik yang tidak mempunyai adaptasi yang cepat dengan adanya kondisi ini, akan merasa kebingungan dengan perubahan pola pembelajaran, sebagai contoh dengan keterkaitan teknologi maka akan ada kendala yang dihadapi diantaranya aplikasi yang error, device yang belum mendukung, disamping itu masih ada kendala kurangnya kuota, pendidik dan fasilitas lainnya.

\section{Solusi Kebijakan Pendidikan Pascapandemi Covid-19}

Kaitannya dengan Kondisi Pandemi saat ini, yang menjadi salah satu bagian dari distrupsinya pendidikan, maka pemerintah harus cerdas, cepat dan tepat dalam merubah paradigma yang ada dengan kebijakan yang breakthrough sehingga dapat merancang alternative kebijakan pendidikan, yakni dengan (a) Penyesuaian kurikulum, dengan adanya kondisi yang darurat seperti saat ini sangat memungkinkan bagi pemerintah membuat sebuah kurikulum yang baru dengan menyesuaikan keadaan pandemi seperti sekarang. Dengan adanya kurikulum baru dan pemberian kuota belajar dapat meningkatkan kualitas dari pembelajaran online beserta peran orang tua sebagai mitra dalam belajar anak. (b) Mendorong Kemendikbudristek RI memastikan kedisplinan dalam pelaksanaan protokol kesehatan dengan benar di setiap satuan pendidikan 
yang melaksanakan PTM Terbatas, termasuk jaminan setiap peserta didik, pendidik dan tenaga kependidikan mendapatkan screening test. (c) Mendukung upaya pemerintah untuk segera menuntaskan vaksinasi kepada PTK guna menunjang rencana sekolah menyenggarakan PTM terbatas. (d) Menjaga kualitas penyelenggaraan pembelajaran jarak jauh dengan tetap memperhatikan kondisi geografis wilayah Indonesia terutama yang berada di wilayah blank spot internet baik diperkotaan, pedesaan dan daerah 3T.

\section{Kesimpulan}

Banyak hal yang terjadi pada fenomena pembelajaran online di saat pandemi ini, mulai dari problematika daring, adanya kelebihan dan kekurangan dari sistem pembelajaran jarak jauh dan solusinya. Kesiapan sekolah dalam menghadapi situasi mendadak seperti ini sangat diuji dan menjadi tugas keseluran elemen pendidikan. Transformasi pembelajaran tentunya menjadi sebuah bentuk perbuahan pembelajaran bukan lagi karena situasi yang mendesak. Strategi transformasi pembelajaran yang cepat dan tepat sangat dibutuhkan, dengan adanya kebijakan yang mendukung dan memberdayakan (memerdekakan) guru serta mendorong pembelajaran digital, menguatkan proses belajar guru dan dukungan institusi pendidikan serta masyarakat.

\section{Daftar Pustaka}

Benyamin, P. I. (2020). Peran Keluarga dalam Pendidikan Anak pada Masa Pandemi Covid-19. Kharismata: Jurnal Teologi Pantekosta, 3(1). https://doi.org/10.47167/kharis.v3i1.43 
Dewi, E. U. (2020). Pengaruh Kecemasan Saat Pembelajaran Daring Masa Pandemi Covid-19 Terhadap Prestasi Belajar Mahasiswa Stikes William Surabaya. Jurnal Keperawatan, https://doi.org/10.47560/kep.v9i1.210

$9(1)$.

Pawicara, R., \& Conilie, M. (2020). Analisis Pembelajaran Daring Terhadap Kejenuhan Belajar Mahasiswa Tadris Biologi. Alveoli: Jurnal Pendidikan Biologi, $1(1)$.

Santosa, A. B. (2020). Potret Pendidikan di Tahun Pandemi : Dampak COVID-19 Terhadap Disparitas Pendidikan di Indonesia. CSIS Commentaries.

Setyawan, D. N., \& Wijayanti, A. (2020). Analisis Kebutuhan Buku Ajar Pendamping IPA Terpadu Berbasis Tri Nga (Ngerti, Ngrasa, Nglakoni) untuk Siswa SMP di Masa Pandemi Covid-19. Wacana Akademika: Majalah Ilmiah Kependidikan, 4(2). https://doi.org/10.30738/wa.v4i2.8714

Supardi. (2012). Arah Pendidikan Di Indonesia. Arah Pendidikan Di Indonesia Dalam Tataran Kebijakan Dan Implementasi, 121(4).

Undang-undang Nomor 20 tahun 2003 tentang Sistem Pendidikan Nasional

Vito, B., \& Krisnani, H. (2015). Kesenjangan Pendidikan Desa Dan Kota. Prosiding Penelitian Dan Pengabdian Kepada Masyarakat, $2(2)$. https://doi.org/10.24198/jppm.v2i2.13533 


\section{SOLUSI MENGATASI \\ BADAI PENGANGGURAN \\ DI MASA PANDEMI COVID 19}

\section{Khalish Khairina, M.Si ${ }^{24}$ \\ Institut Agama Islam Negeri Lhokseumawe}

"Meningkatnya jumlah nilai pengangguran di masa covid 19 menjadi prioritas pemerintah mengupayakan beberapa solusi untuk mengatasinya"

Pandemi Covid 19 yang melanda Indonesia pada Maret 2020 telah menyebabkan banyak perubahan sosial masyarakat, dimulai dari adanya peraturan Work From Home (WFH) dari pemerintah, pembelajaran daring yang harus dijalani siswa dan mahasiswa, hingga ritual ibadah yang dianjurkan dilaksanakan di rumah saja. Pandemi yang sudah lebih dari satu tahun ini melanda negeri ini, begitu banyak membuat perubahan pada kondisi masyarakat, tidak hanya tentang kesehatan tapi juga perekonomian masyarakat Indonesia, mulai dari menurunnya konsumsi masyarakat, melambatnya perekonomian, serta badai pengangguran akibat banyaknya masyarakat yang kehilangan mata pencaharian karena di PHK oleh

24Penulis lahir di Deli Serdang, 31 Desember 1988, penulis merupakan Dosen IAIN Lhokseumawe dalam bidang Ekonomi Mikro dan Makro Islam, Ekonomi Regional, dan Investasi Syariah. Penulis menyelesaikan gelar Sarjana Pendidikan Ekonomi di Universitas Negeri Medan (2011), dan gelar Magister di Universitas Negeri Medan prodi Ilmu Ekonomi (2017). 
perusahaan yang tidak mampu untuk membayar upah mereka.

Meningkatnya jumlah pasien covid 19 pada tahun 2021 memaksa pemerintah untuk menerapkan peraturan PPKM (Pemberlakuan Pembatasan Kegiatan Masyarakat) hingga level 4 untuk menekan angka lonjakan pasien covid 19. Peraturan yang membatasi pergerakan masyarakat ini sedikit banyaknya berdampak kepada jumlah pengangguran yang ada di Indonesia. Sektor yang terdampak akibat peraturan ini terutama adalah sektor pariwisata, perdagangan, manufaktur, konstruksi, jasa, dan sektor transportasi.

Tenaga kerja merupakan salah satu dari faktor - faktor produksi. Sehingga apabila terjadi pengangguran dalam sebuah perekonomian, maka akan terjadi hambatan produksi barang dan jasa. Hal ini seterusnya akan menyebabkan perlambatan ekonomi (deflasi) dan tidak dapat memenuhi permintaan masyarakat terhadap barang hasil produksi. Peraturan yang dikeluarkan pemerintah terkait PSBB dan PPKM, menyebabkan banyak perusahaan yang terpaksa harus menutup usahanya, perusahaan perusahaan ritel besar di Indonesia, seperti Giant, Matahari, Centro, dan Gramedia terpaksa menutup beberapa gerai gerainya. Giant sendiri sudah menutup seluruh gerai pada akhir Juli 2021 kemarin.

Alasan perusahaan - perusahaan ritel ini menutup gerainya lantaran tak mampu untuk menutupi biaya operasional, seperti membayar upah karyawan, ditambah lagi sedikitnya pelanggan yang berkunjung ke gerai karena adanya peraturan yang mengatur tentang pembatasan mobilitas masyarakat. Dampak dari tutupnya perusahaan ini, tentu akan menambah jumlah pengangguran mengingat 
perusahaan ritel ini banyak menyerap tenaga kerja, dan karyawan yang terdampak akibat penutupan gerai mereka tentu akan menambah jumlah pengangguran di Indonesia.

Berdasarkan data yang dipublikasi oleh Badan Pusat Statistik (BPS) Indonesia, jumlah pengangguran terbuka di Indonesia sejak Februari 2020 mengalami peningkatan. Pada Agustus 2020 terjadi peningkatan tingkat pengangguran di Indonesia, yang semula pada bulan Februari sebanyak 4,94\% meningkat menjadi 7,07 persen per Agustus 2020. Pada Februari 2021, tingkat pengangguran mengalami penurunan dibandingkan Agustus 2020 menjadi 6,26\%. Meskipun mengalami penurunan, tetapi tingkat pengangguran ini masih tinggi dibandingkan dengan bulan Februari 2020.

Masih berdasarkan data yang dirilis BPS, pada Februari 2021 penduduk usia kerja yang terdampak covid 19 per Februari 2021 sebanyak 19,10 juta penduduk, terdiri dari penggangguran karena covid 19 sebanyak 1,62 juta orang, Bukan Angkatan Kerja (BAK) karena Covid 19 sebanyak 0,65 juta orang, sementara tidak bekerja karena covid 19 sebanyak 1,11 juta orang, pekerja yang mengalami pengurangan jam kerja karena covid 19 sebanyak 15,72 juta orang.

Pengangguran merupakan sekelompok angkatan kerja yang belum melakukan kegiatan menghasilkan uang [7]. Pengangguran adalah suatu keadaan dimana seorang yang sudah tergolong angkatan kerja ingin mendapatkan pekerjaan tapi belum mendapatkannya [8]. Sedangkan menurut BPS, berdasarkan konsepnya, pengangguran terbuka terdiri dari, mereka yang tak punya pekerjaan dan mencari pekerjaan, mereka yang tak punya pekerjaan dan mempersiapkan usaha, mereka yang tak punya pekerjaan 
dan tidak mencari pekerjaan, karena merasa tidak mungkin mendapatkan pekerjaan, serta mereka yang sudah punya pekerjaan, tetapi belum mulai bekerja.

Penggangguran merupakan masalah makroekonomi yang mempengaruhi manusia secara langsung dan merupakan masalah yang paling berat [9]. Menjadi pengangguranmenyebabkan dampak psikologis dan beban bagi yang mengalami, dikarenakan dihubungkan dengan ketidakmampuan untuk menghasilkan pendapatan bagi keluarganya. Dalam proses produksi sendiri, tenaga kerja merupakan faktor dan fungsi produksi. Sehingga, jika tenaga kerja berkurang, maka proses produksi juga akan terhambat. Hal ini akan berdampak terhadap perekonomian secara umum, terjadinya deflasi dan perlambatan ekonomi.

Para karyawan yang diberhentikan sementara waktu karena adanya pandemi covid 19, pasti akan membutuhkan waktu untuk mencari pekerjaan yang sesuai dengan keahlian dan keinginan mereka. Mereka juga tentu tidak mempunyai pendapatan untuk menafkahi keluarganya. Tidak adanya pendapatan ini, menyebabkan daya beli dan konsumsi masyarakat menurun. Seperti yang diketahui, bahwa konsumsi masyarakat merupakan faktor yang mempengaruhi pendapatan nasional. Sehingga, badai pengangguran yang terjadi akibat covid 19 ini merupakan masalah serius yang mesti diatasi dan dicarikan solusinya.

Pemerintah Indonesia melalui Kementerian Tenaga Kerja (kemnaker) telah mengeluarkan beberapa langkah kebijakan untuk mengurangi tingkat pengangguran. Kebijakan tersebut adalah pertama, memberikan stimulus dana kepada pelaku usaha. Dengan memberikan bantuan dana kepada pelaku usaha, maka diharapkan, pelaku usaha yg menerima stimulus, tetap mampu menjalankan 
usahanya. Sehingga karyawan - karyawan tidak di PHK dan dapat menekan angka pengangguran.

Kedua, Pemerintah menyediakan banyak program yg bertujuan untuk memberikan insentif pajak penghasilan, keringanan pembayaran kredit, dan keringanan iuran jaminan sosial ketenagakerjaan. Hal ini dilakukan untuk meringankan beban para pekerja sektor formal.

Ketiga, pemerintah telah menyediakan jaring pengaman sosial bagi pekerja sektor informal. Bagi pekerja sektor informal, maka pemerintah Indonesia telah memberikan bantuan sosial kepada pekerja di sektor informal yang masuk kategori rentan terhadap PHK dan miskin.

Keempat, Melalui Program Kartu Prakerja, maka pemerintah Indonesia, memprioritaskan pemberian insentif pelatihan bagi pekerja yg telah kena PHK. Target yg ingin dicapai oleh Pemerintah sebanyak 3,5 s.d 5,6 juta penerima manfaat. Sedangkan yg masih terealisasi sampai kini, lebih dari 680 ribu penerima manfaat, serta didominasi oleh pekerja korban PHK. Pada masa pandemi seperti ini, maka pelatihan akan dilakukan dengan metode blended (online dan offline). Pemilihan metode online ataupun offline menyesuaikan dengan kondisi penyebaran covid 19 di setiap daerah. Jika daerah zona hijau maka akan diterapkan metode offline, sedangkan jika daerah merupakan zona merah, maka akan dilakukan metode online (daring).

Kelima, Pemerintah menyediakan informasi mengenai lapangan kerja. Informasi ini terintegrasi dengan Sisnaker (Sistema Informasi Ketenagakerjaan). Meskipun dalam keadaan pandemi, masih ada perusahaan yang membutuhkan tenaga kerja. terdapat kurang lebih 11 ribu lowongan kerja yang tersedia di pusat informasi ini. 
Keenam, Pemerintah juga sudah menyediakan panduan bagi perusahaan dan pekerja. Panduan ini mengatur tentang perlindungan pekerja/buruh dan keberlangsungan kegiatan usaha, serta panduann tentang perlindungan pekerja pada kasus penyakit akibat kerja karena Covid-19.

Langkah langkah yang diambil pemerintah tersebut dapat menjadi solusi untuk mengatasi badai pengangguran. Selain kebijakan pemerintah di atas, maka ada beberapa hal yang bisa menjadi solusi untuk mengatasi badai pengangguran selama pandemi ini, yaitu, pertama, urban farming, merupakan salah satu metode bercocok tanam di daerah perkotaan.. Memanfaatkan pekarangan halaman dengan menanam sayuran dan buah-buahan, dengan sistem hidroponik ataupun aquaponik. Adanya peraturan WFH, PSBB, serta PPKM, menyebabkan masyarakat mempunyai waktu luang untuk bercocok tanam. Bagi pekerja yang mengalami PHK oleh perusahaan, bercocok tanam dapat dilakukan untuk memenuhi kebutuhan makanan bagi keluarga. Selain itu, urban farming juga dapat dimanfaatkan sebagai penghasilan tambahan bagi pekerja yang sedang mencari/menunggu pekerjaan.

Kedua, menjual barang secara digital di marketplace, pembatasan mobilitas masyarakat serta pembatasan jam operasional pusat perbelanjaan menyebabkan perubahan pola belanja masyarakat, dari offline menjadi online. Berdasarkan survey terhadap hasil penjualan di marketplace seperti shopee, tokopedia, lazada, dan lain lain. Maka terjadi peningkatan jumlah pembelian di toko online. Di tokopedi, terjadi peningkatan jumlah volume penjualan. Setidaknya peningkatan penjualan ini dirasakan oleh 7 dari 10 pedagang di Tokopedia. Selama pandemi Covid-19, tercatat volume penjualan tersebut meningkat 
hingga 133 persen. Pelaku usaha mikro kecil menengah dapat mempertimbangkan untuk menjual produk mereka di platform marketplace. Pelaku usaha dapat tetap duduk di took sambil juga menjual barang secara online. Sehingga hal ini dapat membantu untuk meningkatkan omzet penjualan.

Badai pengangguran ini belum dapat ditentukan kapan akan segera berakhir, tapi paling tidak, pemerintah telah membuat dan menjalankan kebijakan untuk mengatasi hal ini. Selama menunggu dan mencari pekerjaan, urban farming dan menjual barang di marketplace secara digital dapat menjadi solusi untuk mengatasi masalah pengangguran ini.

\section{Daftar Pustaka}

Alil, Abdul., Fahri., Kasnelly, Sri. (2020). Meningkatnya Angka Pengangguran di Tengah Pandemi (Covid19). Almizan: Jurnal Ekonomi Syariah, Volume 2, Edisi 2 (Desember 2019). e-ISSN:2656-968X,p-ISSN: 26584228.

Mankiw, N. Gregory. 2007. Makroekonomi. Jakarta: Erlangga

Sukirno, Sadono. 2006. Makroekonomi: Teori Pengantar. Jakarta: Raja Grafindo Persada 


\section{JURNALISME KEMANUSIAAN PADA \\ MASA PANDEMI COVID-19}

\section{Supriadi, MM 25 \\ STAI Bumi Silampari Lubuklinggau, Sumatera Selatan}

"Sumber informasi dapat diperoleh dari berbagai sumber, kegiatan jurnalisme hendaknya menjunjung tinggi pada nilai-nilai kemanusiaan"

Pada kondisi pandemi covid-19 saat ini, kegiatan jurnalistik yang juga dikenal dengan jurnalisme memiliki peranan yang sangat penting. Penting karena menjadi sumber informasi yang memberitakan perkembangan/kejadian atau semua hal yang menyangkut dengan pendemi covid-19. Pemberitaan mulai dari masyarakat yang terjangkit virus covid-19, masyarakat yang diisolasi baik dengan terpaksa atau dengan mandiri, adanya vaksinasi ke masyarakat, bantuan sosial, bahkan juga berita yang menyangkut penyelewengan dana covid atau vaksin yang dipalsukan oleh oknum dan masih banyak lagi berita terkait covid lainnya.

25Penulis lahir di Palembang, 13 September 1980, penulis merupakan Dosen di STAI Bumi Silampari dalam bidang ilmu Kewirausahaan dan Jurnalistik, penulis menyelesaikan gelar Sarjana di Universitas Sriwijaya (2005), sedangkan gelar Magister Manajemen diselesaikan di Universitas Bina Insan Lubuklinggau sebelumnya Pascasarjana STIE Mura Lubuklinggau (2017), dan sekarang sedang menempuh program Doktoral di Universitas Islam Negeri Suultah Thaha Saifuddin (2021) sesuai pengumuman Hasil Seleksi Mahasiswa Baru program doktoral 2021. 
Berita yang ada saat ini sangat banyak tersebar terutama sejak adanya berita online dan media sosial yang juga berkembang banyak menjadi fenomena tersendiri dalam jurnalisme. Jurnalisme sendiri sebenarnya memiliki kekhususan / kekhasan nya tersendiri dalam pemberitaan. Hanya saja, saat ini begitu banyak jurnalis (sebutan orang / praktisi dalam jurnalistik) yang masih belum menggunakan kaidah penulisan jurnalistik mulai dari cara penulisan yang mengandung unsur $5 \mathrm{~W}+1 \mathrm{H}$ atau bahkan jauh dari kode etik jurnalistik sebagaimana telah dibuat oleh Dewan Pers Republik Indonesia.

Dalam konteks jurnalisme saat pandemi ini, penulis ingin mengajak insan pers maupun masyarakat secara umum untuk juga melihat segala sesuatu dalam perspektif kemanusiaa (humanisme). Perspektif kemanusiaan yang dimaksud adalah melihat pemeberitaan yang ditampilkan atau dipublikasikan dari sisi maslahah, yaitu apakah lebih banyak mencapai manfaat dengan pemberitaan yang ada dan menolak mudharatnya [10].

\section{Humanisme Sebuah Pilihan}

Saat ini, kita sedang menghadapi banyak persoalan yang beraneka ragam dan membingungkan mulai dari awal berkembangannya pandemi sampai dengan proses mengatasi pandemi. Selain wabah pandemi yang ada, terdapat pihak masyarakat menjadi kian kompleks dengan pluralisme nilai-nilai didalamnya yang seringkali membawa konsekuensi relativisme nilai-nilai tersendiri. Sistem nilai universal atau apa yang oleh Jean Francois lyotard disebut Grand narrative mulai kehilangan kredibilitasnya, dan humanisme termasuk di dalamnya. Di lain pihak masyarakat sedang mengalami kebangkitan agama, padahal agama juga termasuk dalam sistem nilai yang menawarkan kebenaran 
universal dan terkadang siap bersaing dan kerap dengan keras kepala untuk merebut kursi tafsir atas kebenaran yang relatif (Hardiman, 2012). Dengan kata lain humanisme yang ada sekarang hampir tergerus manakala akal sehat kalah dengan nafsu yang ada.

Kondisi covid ini membuat kita memilih karena memilih adalah bagian dari hak asasi manusia itu sendiri. Seyogya nya sikap keras kita yang juga bagian dari hak yang kita miliki harus melihat dampak positif yang paling banyak dibandingkan dampak negatifnya. Hal ini dikarenakan setiap yang kita lakukan memiliki potensi positif dan potensi negatif.

\section{Jurnalisme Masa Pandemi}

Kegiatan jurnalisme pada pasa pandemi ini harus benar-benar memperhatikan aspek kemanusiaan. Pemberitaan yang berlebih-lebihan tanpa memandang aspek kebermanfaatan yang banyak, maka akan menghasilkan ketakutan di tengah-tengan masyarakat. Benar adanya jika kita harus membuat berita yang sesuai dengan fakta yang diperoleh lapangan, tetapi kita juga harus berpedoman dengan kode etik jurnalistik yang ada.

Sebagai contoh misalnya di awal pandemi terjadi ada seorang anak berusia 16 tahun yang meninggal dengan kondisi sakit dan diduga penyebabnya covid-19. Dalam hal pemberitaan yang dibuat oleh seorang jurnalis harus lah sesuai fakta tetapi harus berpedoman dengan mengunakan kode etik. Misalnya, nama anak tersebut disamarkan, kemudian alamat tinggal hanya dibuat sampai dengan kecamatan, tidak perlu ditulis alamat lengkap sampai dengan RT berapa RW berapa bahkan nomor rumah dan tetangga kiri kanan bernama kepala keluarga siapa, terlebih 
foto anak dan keluarga yang tidak terkena covid ditampilkan di bagian headline.

Dari contoh ini, perspektif kemanusiaan harus digunakan dalam penulisan jurnalistik bukan hanya sekedar berita tetapi juga ada unsur perlindungan untuk objek berita juga untuk keluarganya. Bersyukur saat ini, kondisi covid sudah mengalami penurunan, kegiatan pendidikan, sosial, budaya sudah mulai dilaksanakan kembali di beberapa daerah meski harus menggunakan protokol kesehatan covid-19 dengan menggunakan masker, mencuci tangan, dan menjaga jarak dan tentunya dengan menjaga imun tubuh masing-masing.

Jurnalisme yang membangun kesadaran pentingnya protokol kesehatan saat ini jauh lebih banyak manfaatnya dibandingkan jurnalisme yang hanya membuat rasa takut di masyarakat. Jurnalisme yang mengedukasi masyarakat dalam banyak hal yang berhubungan dengan bagaimana cara hidup sehat, makanan apa saja yang bisa dikonsumsi untuk menambah imun atau untuk penyembuhan bagi masyarakat yang melakukan isolasi mandiri akan jauh lebih bermakna dan bermartabat.

Meskipun begitu, fungsi untuk lain dari jurnalistik juga harus dilaksanakan sebagai upaya penyeimbang dalam konteks media saat ini.

\section{Kode Etik, Dewan Pers dalam Jurnalisme Kemanusiaan}

Setiap jurnalis harus memiliki kode etik yang terangkum dalam Kode Etik Jurnalistik (KEJ), yang memuat himpunan etika profesi kewartawanan. Dalam Konteks kemanusiaan, KEJ sudah memuat seluruh hal yang diperlukan dalam rangkaian kegiatan kewartawanan. 
Keberadaan Dewan Pers sebagaimana dalam UU nomor 40 tahun 1999 tentang Pers memiliki peranan yang sangat penting terutama untuk mengatasi persoalan-persoalan pers yang tidak profesional. Sebagaimana disebutkan dalam Undang-undang tersebut pada pasal 15 menyebut bahwa pembentukan Dewan Pers sebagai upaya mengembangkan kemerdekaan pers dan meningkatkan kehidupan pers nasional. Terdapat tujuh fungsi Dewan Pers sebagaimana amanat Undang Undang Pers antara lain; melindungi kemerdekaan pers dari campur tangan pihak lain, melakukan pengkajian untuk pengembangan pers, pelaksanaan kode etik jurnalistik, penyelesaian pengaduan kasus pers, penyusunan peraturan di bidang pers, dan pendataan pers (Dewanpers, 2013).

Sebagai amanah UU Pers, Dewan Pers dapat memberikan kepastian hukum sebagai akibat pelanggaran kode etik jurnalistik yang dilakukan oleh jurnalis atau media yang menerbitkan semua produk pers yang ada. Dewan Pers seyogyanya dapat mengusulkan penutupan perusahaan pers yang membandel dalam hal penerbitan berita yang melanggar aturan perundang-undangan pers maupun kode etik jurnalistik begitu juga denga jurnalis yang tidak mematuhi kEJ.

\section{Masyarakat, Jurnalis, Kemanusiaan pada Masa Pandemi}

Masyarakat diharapkan juga dapat mengkritisi produk pers yang ada secara bijak. Jika dalam melakukan pemberitaan, sebuah media pers dapat diminta hak jawab atau dengan kata lain masyarakat dapat menggunakan Hak Jawab. Hak jawab ini sangat berguna bagi masyarakat yang nama baiknya dicemarkan karena penerbitan berita yang tidak sesuai dengan fakta. Sebagai contoh pemberitaan yang memberitakan berita dengan judul "Pak A, Seorang Kepala 
Dinas Kabupaten terkena Covid-19 dan Membuat Cluster Baru", padahal faktanya tidak benar atau faktanya belum lengkap karena masih dalam proses pemeriksaan pcr atau swab pihak rumah sakit/tim kesehatan. Nah, dengan berita yang tidak sesuai fakta ini, kita sebagai masyarakat bisa menggunakan hak jawab di media tersebut, dan pihak media wajib untuk mempublikasikan hak jawab tersebut.

Sesuai dengan Undang-undang Pers, pers berkewajiban memberikan peristiwa dan opini dengan menghormati norma-norma agama dan rasa kesusilaan masyarakat serta asas praduga tak bersalah, pers juga wajib melayani Hak Jawab dan bagi perusahaan pers yang melanggar dipidana dengan pidana denda paling banyak Rp. 500.000.000,- (lima ratus juta rupiah).

\section{Daftar Pustaka}

DewanPers. 2013. Pers Berkualitas, Masyarakat Cerdas. Jakarta DewanPers

Fauzi. 2017. Hak Asasi Manusia dalam Fikih Kontemporer. Jakarta. Prenada Media Group.

Hardiman, F Bud. 2012. Humanisme dan Sesudahnya. Jakarta. KPG (Kepustakaan Populer Gramedia)

Undang-Undang Republik Indonesia Nomor 40 Tahun 1999 Tentang Pers. 


\title{
MELAWAN STIGMA SOSIAL AKIBAT PANDEMI COVID-19
}

\author{
Marianus Yufrinalis ${ }^{26}$ \\ Universitas Nusa Nipa Indonesia
}

“Covid-19 adalah penyakit yang dapat disembuhkan dan bukan aib bagi penderitanya, kerap masyarakat menolak keberadaan seseorang karena terjangkit penyakit tersebut,

marilah bersama-sama melawan stigma sosial dengan proaktif untuk membangun nalar positif"

Pandemi Covid-19 yang melanda dunia kini memasuki tahun kedua di Indonesia semenjak kemunculannya secara masif pada bulan Maret 2020 lalu. Selama dua tahun ini pemerintah dan rakyat telah berperang melawan dampak pandemi yang telah merugikan berbagai sendisendi kebutuhan masyarakat. Semua orang tidak bisa bergerak bebas dalam upaya pemenuhan kebutuhan hidupnya dan aktualisasi diri lainnya karena dibatasi oleh dampak pandemi yang mematikan. Pandemi telah merenggut segala hal, bahkan karakter manusia pun turut berubah seiring kemunculannya yang kian hari kian memburuk dampaknya.

26Penulis lahir di Maumere pada tanggal 18 Februari 1987, penulis merupakan Dosen Ilmu Sosial Dasar dan Filsafat Pendidikan pada Program Studi PGSD Universitas Nusa Nipa Indonesia di Maumere, Flores, NTT. Penulis menyelesaikan gelar sarjana Ilmu Filsafat di STFK Ledalero, Maumere, Flores, NTT (2010). Kemudian penulis melanjutkan pendidikan magister Ilmu Sosiologi di Pascasarjana FISIPOL Universitas Gadjah Mada Yogyakarta (2013). 
Seiring dengan kemunculannya sebagai penyakit infeksi yang membunuh jutaan umat manusia hingga saat ini, dampak keberadaanya telah menciptakan asumsi baru yang mempengaruhi cara pandang setiap orang yang mengalaminya. Asumsi baru yang disematkan kepada penderita Covid-19 dalam pengalaman kehidupan bermasyarakat kemudian muncul sebagai stigma sosial; suatu cara pandang yang mendiskreditkan para pengidap wabah ini sebagai individu yang patut dijauhi, ditinggalkan dan diabaikan dalam kesehariannya. Stigma sosial kepada para pengidap wabah Covid-19 menitikberatkan pada anggapan bahwa mereka (para penderita) sedang memikul penyakit jahat dan mematikan, yang mendapat kutukan, dan harus diabaikan agar tidak memberi dampak luas bagi komunitas masyarakat tertentu. Stigma sosial terhadap para penderita wabah Covid-19 ini lalu muncul sebagai cara pandang yang dibiasakan dan diterima pada kelompok masyarakat itu.

\section{Apa Itu Stigma Sosial?}

Stigma sosial adalah tidak diterimanya seseorang pada suatu kelompok karena kepercayaan bahwa orang tersebut melawan norma yang ada. Stigma sosial sering menyebabkan pengucilan seseorang ataupun kelompok (2021). Menurut Kamus Besar Bahasa Indonesia, stigma adalah ciri negatif yang menempel pada diri seseorang karena pengaruh lingkungannya (2021). Goffman (1963: 127) mendefinisikan stigma sebagai kepemilikan beberapa atribut yang menyebabkan individu diklasifikasikan dalam (dan ditanggapi sebagai anggota) kategori sosial yang "didiskreditkan". Pada sisi lain, orang yang tidak mendapatkan stigma disebut sebagai orang normal. Orang yang normal dapat saja mendiskriminasi dan sebaliknya 
mereka yang terstigmatisasi bereaksi dengan cara yang tidak menyenangkan terhadap stigma, dan membenci perlakuan yang diterimanya. Definisi ini memiliki asumsi bahwa orang yang distigmatisasi memiliki (atau diyakini memiliki) atribut yang menandai mereka berbeda dan membuat mereka direndahkan di mata orang lain (Major dan O’Brien dalam Heatherton, et.al., 2000 : 395).

Berdasarkan beberapa pendapat di atas, maka disimpulkan bahwa stigma sosial adalah predikat yang diberikan pada kondisi tertentu dari seorang individu sebagai sesuatu yang tidak dapat diterima, diakui, dan mendapat perhatian dari orang lain. Stigma sosial terhadap individu tertentu menitikberatkan pada adanya batasanbatasan sosial tertentu yang membuat individu tersebut tidak mendapatkan akses pada pengakuan dan penghargaan dari orang lain.

\section{Melawan Stigma Sosial Pandemi Covid-19}

Kita sering mendengar pemberitaan di berbagai media massa dan sosial media terkait stigma sosial yang disematkan pada pasien atau penderita wabah Covid-19. Berbagai penolakan warga masyarakat terhadap keberadaan pasien Covid-19 ataupun yang menjadi korban keganasan wabah ini sering mengisi ruang informasi kita setiap hari. Berbagai alasan dapat diketahui, di antaranya adanya anggapan wabah Covid-19 sebagai suatu penyakit yang mematikan, sehingga mereka yang terdampak Covid19 sepatutnya dijauhi dan ditinggalkan. Selain itu, penderita Covid-19 dan anggota keluarganya sering mendapat pengucilan dari anggota masyarakat di sekitarnya, termasuk terisolasi dari upaya pemenuhan kebutuhan sehari-hari. Stigmatisasi dirasakan juga oleh ODP (Orang Dalam Pengawasan), PDP (Pasien dalam Pengawasan), eks pasien 
Covid-19 bahkan tenaga kesehatan yang menangani pasien Covid-19 (Novita dan Elon, 2021: 29). Kurangnya perhatian dan pendampingan terhadap penderita Covid-19 juga menyebabkan mereka semakin terisolir dan diabaikan oleh masyarakat sekitar.

Sebagai penyakit baru yang belum ditemukan obatnya, wabah Covid-19 dalam tatanan sosial masyarakat telah memunculkan terjadinya stigmatisasi terhadap orang atau kelompok tertentu. Menurut World Health Organization (2020), dari perspektif kesehatan stigma sosial adalah hubungan negatif antara seseorang, sekelompok orang yang berbagi karakteristik dan penyakit tertentu. Adanya stigma ini mendorong orang yang terjangkit Covid-19 beusaha menyembunyikan penyakitnya agar terhindar dari diskriminasi secara sosial, mencegah orang atau pribadi tertentu yang terjangkit untuk mendapatkan perawatan sesegara mungkin, dan mencegah orang untuk berperilaku pola hidup bersih dan sehat. Kondisi ini tentu saja turut berpengaruh pada upaya pencegahan dan percepatan penangangan wabah Covid-19. BeritaSatu.com (2020) merilis bahwa justru pola pikir dan perilaku masyarakat yang mengucilkan dan menjauhi pasien positif Covid-19 mungkin terjadi akibat adanya rasa takut yang berlebihan. Stigma yang diberikan sangat melukai hati seseorang atau sekelompok orang bahkan lebih berdampak buruk daripada virus corona itu sendiri (Herdiana, 2020).

Stigma sosial terkait Covid-19 dapat merusak kohesi sosial dan mendorong terjadinya isolasi sosial terhadap kelompok, yang dapat berkontribusi pada situasi yang justru lebih memungkinkan, bukan mencegah penyebaran virus dan upaya pengendaliannya. Stigma dan ketakutan seputar penyakit menular ini menghambat respons banyak 
pihak untuk bergerak cepat melakukan penanganan. Sedangkan pada sisi lain, tindakan yang membantu adalah membangun kepercayaan pada layanan dan sarana kesehatan yang terpercaya, menunjukkan empati pada mereka yang terdampak, dan mengambil langkah praktis dan efektif untuk membantu menjaga diri sendiri dan orang-orang yang dicintai agar tetap aman.

Adapun cara kita berkomunikasi seputar Covid-19 sangat penting dalam mendukung orang-orang untuk mengambil tindakan efektif guna membantu melawan penyakit tersebut beserta dampak yang ditimbulkannya. Akan sangat bermanfaat apabila lingkungan yang kondusif dan memberi ruang empati pada banyak orang, terutama kepada mereka yang terdampak Covid-19.

Menurut WHO (2020), ada beberapa cara atau kiat untuk menghadapi stigma sosial akibat dampak Covid-19 serta upaya untuk melawannya. Beberapa kiat sederhana yang dapat dilakukan adalah sebagai berikut :

1. Memberi dukungan positif melalui ujaran dan pola pikir serta pola sikap yang toleran. Saat kita berbicara tentang penyakit Covid-19, kata-kata tertentu seperti kasus suspek, isolasi dan pemilihan kata tertentu mungkin memiliki arti negatif bagi orang-orang dan memicu terjadinya stigmatisasi secara sosial. Pemilihan kata yang bernuansa negatif dapat menguatkan stereotip atau asumsi negatif yang ada, memperkuat anggapan pada konsep penyakit yang mematikan, menciptakan ketakutan yang meluas, dan merendahkan martabat orang yang mengidap penyakit tersebut. Hal ini justru dapat membuat orang menghindari adanya pemerikaan, tracing, dan karantina. Maka dari itu, 
perlu direkomendasikan untuk menggunakan bahasa dan pemilihan kata-kata yang mengutamakan nilai-nilai kemanusiaan dan rasa solider satu terhadap yang lain.

2. Membangkitkan inisiatif pribadi untuk memberi pengaruh dari lingkup kecil ke lingkup yang lebih luas. Dalam hal ini, kiat-kiat yang perlu dilakukan dimulai dengan hal-hal sederhana, seperti menyebarkan fakta bukan hoaks seputar penyeberan wabah Covid-19; mengajak para influencer dan pemberi pengaruh sosial lainnya untuk memberikan pemahaman tentang bahaya stigmatisasi Covid-19; melakukan propanga positif untuk mendukung kinerja petugas kesehatan yang menangani pasien Covid-19; bijak menggunakan media sosial untuk mewartakan kebenaran; serta mendorong terjadinya kesetiakawanan sosial dengan turut berempati dan memberi dukungan moril bagi mereka yang terdampak wabah Covid-19.

3. Memberi pesan positif dan komunikasi yang membangun. Hal-hal yang dapat dilakukan untuk mendukung terwujudnya percepatan penanganan wabah Covid-19 antara lain: menghindari terjadinya kesalahpamahan, rumor, dan informasi yang salah yang dapat berkontribusi menimbulkan stigma dan diskriminasi yang menghambat upaya pemulihan; perbaiki kekeliruan dan promosikan upaya pencegahan; menebarkan rasa solidaritas kolektif dan kesetiakawanan sosial melalui narasi yang simpatik dan memberi dukungan positif bagi para penyintas wabah Covid-19; serta mengajak semua orang untuk menghindari rasa takut terhadap 
wabah Covid-19 dan bekerja sama mengatasi dampak pandemi.

Demikian beberapa kiat yang bisa dimulai dalam upaya melawan bahaya stigmatisasi sosial terhadap orang-orang terdampak pandemi Covid-19 ataupun mereka yang turut mengalami stigma sosial dan diskriminasi dari orang orang sekitar yang merasa takut berlebihan akan wabah Covid-19. Karena bisa jadi ketakutan dan kekhawatiran yang berlebihan yang menjadi penyebab imunitas tubuh menjadi turun dan gampang diserang oleh wabah Covid-19. Maka dukungan positif dan perilaku yang mencerminkan rasa solider dan kesetiakawanan sosial dapat membantu semua orang terdampak wabah Covid-19 bisa kembali pulih dan memenangkan perlawanan terhadap penyakit tersebut.

\section{Daftar Pustaka}

Berita Satu. 2020. Hilangkan Stigma Negatif Buruh Terdampak Covid-19. dalam https://www.beritasatu.com/nasional/628871/hila ngkan-stigma-negatif-bagi-buruh-terdampak$\underline{\text { covid19 }}$, diakses pada tanggal 13 Agustus 2021

Goffman, Erving. 1963. Stigma : Notes on the Management of Spoiled Indentity. Englewood Cliffs, New Jersey : Prentice-Hall.

Heatherton, T. F., Kleck, R. E., Hebl, M. R., \& Hull, J. G. (Eds.). 2000. The Social Psychology of Stigma, New York City: Guilford Press

Herdiana, Ike. 2020. Stigma Saat Pandemi Covid-19 dan Tindakan Melawannya. Surabaya: Fakultas Psikologi Unair, dalam https://psikologi.unair.ac.id/wpcontent/uploads/2020/05/04-Stigma-SaatPandemi-COVID-19-dan-Tindakan-Melawannya.pdf, diakses pada tanggal 14 Agustus 2021 
Kamus Besar Bahasa Indonesia. 2021. Stigma. dalam https://kbbi.web.id/stigma, diakes pada 13 Agustus 2021

Novita, Syntha dan Yunus Elon. 2021. Stigma Masyarakat Terhadap Penderita Covid-19. Jurnal Kesehatan Politeknik Kesehatan Kemenkes Tanjung Karang, Vol. 12, No. 1, April 2021, hal. 25-33, dalam https://ejurnal.poltekkes-

tjk.ac.id/index.php/IK/article/view/2451, diakses tanggal 14 Agustus 2021

Wikipedia. 2021. Stigma Sosial, dalam

https://id.wikipedia.org/wiki/Stigma sosial, diakses pada 13 Agustus 2021

World Health Organization. 2020. Panduan Untuk Mencegah dan Mengatasi Stigma Sosial. dalam https://www.who.int/docs/ default source/searo/ indonesia/covid19/panduan-untuk-mencegah-danmengatasi-stigma-sosial.pdf? sfvrsn=4f8bc734_2 , diakses pada tanggal 13 Agustus 2021 


\title{
KEBIJAKAN TETAP BEKERJA DARI RUMAH (WORK FROM HOME) DI MASA COVID- 19 DI KANTOR WILAYAH KEMENTERIAN AGAMA PROVINSI ACEH
}

(Implementasi Surat Edaran Kementerian Agama Nomor SE.14 Tahun 2021 Tentang Sistem Kerja Aparatur Sipil Negara (ASN) Pada masa Pandemi Covid 19 Tahun kedua)

\author{
Bahagia, S. Psi. M.Si ${ }^{27}$ \\ Universitas Teuku Umar Aceh Barat
}

"Kebijakan pemerintah mengenai work from home berdasarkan SE.14 Tahun 2021 menekankan kepada para pegawai Kantor Wilayah Kementerian Agama Provinsi Aceh untuk memberikan tauladan mematuhi protokol kesehatan

dan meningkatkan kemampuan ilmu teknologi sebagai prioritas utama dalam mengemban tanggung jawabnya"

\section{Latar Belakang}

Kantor wilayah Kementerian agama Provinsi Aceh adalah

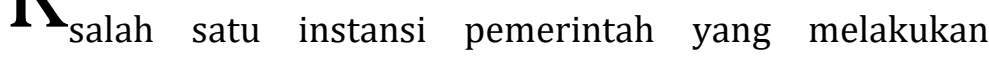
kebijakan tetap bekerja dengan menerapkan bekerja secara tetap bekerja di rumah (word From Home) yaitu tetap

${ }^{27}$ Bahagia S. Psi. M.Si, lahir di Pondok Baru 14 Maret 1988, penulis merupakan dosen tidak tetap di Universitas Teuku Umar Aceh Barat. Penulis menyelesaikan gelar sarjana Psikologi di Harapan Bangsa dan gelar magister di Universitas Iskandarmuda Banda Aceh. 
bekerja dari rumah sebagaimana di ketahui Aceh adalah suatu Provinsi di Indonesia yang juga sedang melakukan proses dalam penyebaran secara luas di lingkungan para pegawai yang bekerja di Kantor Wilayah Kementerian agama Provinsi Aceh, dimasa corona atau di kenal dengan nama lain covid 9 membuat pemerintah memberikan otonomi kepada instansi,provinsi, kota maupun Kabupaten untuk melihat secara luas proses penyebaran covid -19 sehingga instansi-intansi pemerintah tetap dapat memberikan pelayanan kepada Publik khususnya dalam pendidikan, kesehatan, agama dan pastinya ekonomi

Kebijakan ini dilakukan berdasarkan Surat Edaran Nomor SE. 14 Tentang Sistem kerja Aparatur Sipil Negara (ASN) di kementerian agama pada masa pandemi Covid -19 tahun kedua (Surat Edaran Menteri Agama), Namun demikian mekanisme shift juga di terapkan dalam sistem kerja, sehingga pelayanan tetap dapat di berikan kepada masyarakat.sebagai suatu instansi pemerintah di bawah kementerian agama Kantor kementerian agama Provinsi Aceh tidak mau mengambil resiko yang besar sehingga dapat berimbas kepada Aparatur Sipil Negara dan masyarakat dengan penyebaran virus Corona.

Secara kondisi dari 23 Kabupaten dan kota yang ada di provinsi Aceh, banda Aceh adalah sala satu daerah yang memiliki pengaruh besar dalam penyebaran Covid -19 karena adalah salah satu kota terbanyak instansi pemerintah selain memiliki instansi pemerintah kota juga memiliki instansi Provinsi dan juga pusat karena merupakan ibu kota provinsi Aceh.

Dengan kebiasaan kerja di masa pandemi maka seluruh pegawai harus membiasakan memberikan pelayanan secara online dalam memberikan pelayanan 
kepada masyarakat secara online dengan tetap bekerja di rumah ( Hord From Home), dimana semua pekerjaan yang dilakukan oleh para abdi negara baik itu aparatur Sipil Negara,non pegawai, honorer dan tenaga kontrak di wajibkan tetap bekerja namun dilakukan secara online dengan cara berkerja dari rumah sehingga pelayanan publik dan administrasi publik lainya dapat terlaksana dengan baik

\section{Peraturan Undang-undang}

Dalam memberikan keputusan dalam Surat Edaran Nomor SE.14 Tahun 2021 Tentang Sistem Kerja Aparatur Sipil Negara (ASN) Kementerian Agama Pada masa Pandemi Covid -19 Tahun kedua, maka pemerintah menerapkan ketentuan peraturan untuk di laksanakan oleh aparatur Sipil Negara dalam melakukan prilaku hidup sehat sebagaimana di jelaskan oleh Surat Edaran Nomor SE.14 Tahun 2021 Tentang Sistem Kerja Aparatur Sipil Negara (ASN) Kementerian Agama Pada masa Pandemi Covid -19 Tahun kedua yang di keluarkan oleh kementerian agama di dalam huruf E Ketentuan Angkat 2 dan 3 dimana menjelaskan

1. Pengaturan jumlah pegawai sebagaimana di maksud pada ketentuan 1 sebagai berikut :

a. Satuan kerja/Unit kerja kementerian agama yang berada pada zona Kabupaten/Kota berkategori tidak terdampak / Tidak ada kasus ,pimpinan satuan kerja / Unit kerja dapat Mengatur Jumlah Aparatur sipil negara yang melaksanakan tugas kedinasan di kantor (Word From Office) paling banyak $100 \%$ (Seratus Persen); 
b. Satuan Unit kerja /Unit kerja Kementerian agama yang berada pada zona Kabupaten/Kota Berkategori resiko rendah,Pimpinan satuan kerja /Unit kerja dapat mengatur Jumlah Aparatur Sipil negara yang melaksanakan tugas kedinasan di kantor ( Word From Office ) paling banyakl 75 \%( Tujuh Puluh Lima persen)

c. Satuan Unit kerja/Unit kerja Kementerian agama yang berada pada zona Kabupaten/Kota Berkategori resiko sedang, Pimpinan satuan kerja /Unit kerja dapat mengatur Jumlah Aparatur Sipil negara yang melaksanakan tugas kedinasan di kantor ( Word From Office ) paling banyakl 50 \%( Lima Puluh Lima persen);

d. Satuan Unit kerja /Unit kerja Kementerian agama yang berada pada zona Kabupaten/Kota Berkategori resiko Tinggi ,Pimpinan satuan kerja /Unit kerja dapat mengatur Jumlah Aparatur Sipil negara yang melaksanakan tugas kedinasan di kantor ( Word From Office ) paling banyakl $25 \%$ (dua puluh Lima persen);

2. Aparatur Sipil negara Kementerian agama wajib melaksanakan prilaku hidup bersih dan sehat serta menjadi pelopor dan contoh dalam penerapkan 5M dam 3T yaitu adalah sebagai berikut :

a. Menggunakan Masker dengan benar ketika berada atau berkegiatan di luar rumah tanpa kecuali;

b. Mencuci tangan dengan sabuh dan air Mengalir; 
c. Menjaga jarak dengan orang lain ketika melakukan Komunikasi antar Individu ( Psysical Distancing)

d. Menjauhi kerumunan;

e. Membatasi Mobilitas dan Interaksi;

f. Testing atau pemerikasaan dini pada seseorang;

g. Tracing atau pelacakan pada kontak terdekat pasien Coivid -19 dan

h. Treatment atau perawatan yang dilakukan apabila seseorang terkomfirmasi Positif Covid 19.

Dengan demikian menerapkan implementasi Surat Edaran Nomor: SE.14 Tahun 2021 Tentang Sistem Kerja Aparatur Sipil Negara (ASN) Kementerian Agama Pada masa Pandemi Covid -19 Tahun kedua akan menjadi pendoman bagi Aparatur Sipil Negara pda khususnya agar dapat menjadi contoh dan dapat mengajak keluarga serta masyarakat di lingkungan tempat tinggalnya.

\section{Sumber Daya Manusia}

Sumber daya manusia yang Unggul di masa pandemi Covid-19 ini, maka sumber daya manusia yang memiliki pengetahuan lebih dalam bidang Informasi dan teknologi akan memberikan nilai bagus dalam menjalankan roda pemerintahan khsususnya dalam bidang pelayanan, pendidikan,kesehatan dan yang paling utama terhadap pelayanan publik dan administrasi publik karena adalah bagian yang selalu di butuhkan oleh masyarakat, dengan adanya kebijakan-kebijakan yang berbeda dalam bekerja dengan menggunakan teknologi maka Aparatur Sipil Negara sebagai abdi negara akan menjadi tugas baru untuk 
mengembangan sumber daya manusia yang dapat berkerja dengan baik di masa pandemi ini.

Sebagaimana Menurut Sedarmanyanti (2016: 95) menyatakan " komputer telah menyederhanakan tugas menganalisis data dalam jumlah sangat besar, dan dapat menjadi bantuan yang tak ternilai dalam manajemen sumber daya manusia, dengan Piranti keras,piranti lunak, dan basis data Komputer,organisasi tidak hanya dapat menyimpang catatan dan informasikan dengan baik, tetapi juga dapat mengambilnya dengan sangat mudah sistem Informasi sumber daya manusia adalah terintegrasi yang menyediakan informasi yang di gunakan dalam, pembuatan keputusan sumber daya manusia.

Dengan demikian dukungan-dukungan dalam pengembangan sumber daya manusia yang unggul dan baik harus di dukung oleh setiap instansi seperti dalam pelatihan dan pengembangan, peralatan dan teknologi, standar kerja dan pastinya manajemen dan rekan kerja, pola di masa covid -19 kebutuhan sumber daya manusia yang memiliki keterampilan dalam bidang teknologi semakin terasa sangat di butuhkan di hampir semua instansi pemerintah dan swasta, maka perubahan model kerja dalam dunia kerja yang sekarang ini di butuhkan sumber daya manusia dalam membentuk sistem,Prosedur, dan pastinya teknologi baru sebagai dalam bekerja dari rumah (Word From Home).

Ini adalah bagian sistem tantangan yang harus di hadapi dalam kehidupan yang harus memberikan pelayanan secara cepat dan baik tatap harus melakukan secara tatap muka, dengan mengedepanan sumber daya manusia maka instansi akan siap dalam memberikan pelayanan dalam bentuk apapun, maka untuk menciptakan Sumber daya manusia yang demikian di perlukan peran semua 
stakeholder. Semua ini dapat dilakukan dengan adanya pelatihan yang di berikan kepada Aparatur Sipil Negara, sebagaimana sedarmayanti (2016: 174) menjelaskan spesifikasi pekerjaan menunjukkan siapa yang melakukan pekerjaan dan faktor manusia yang disyaratkan, antara lain:

1. Pendidikan

2. Pelatihan

3. Pengalaman

4. Persyaratan Fisif dan mental,

Secara umum jika ini dapat di terapkan maka pelayanan dalam bentuk apapun sumber daya manusia akan siap memberikan pelayanan publik yang memuaskan, khususnya dalam pelayanan yang selalu di butuhkan oleh masyarakat, seperti syarat-syarat dalam adminsitasi dan lain-lain tidak akan menjadi kendala lagi ke depanya walaupun sekelas pandemi covid -19 yang lainnya datang ke depannya maka sumber daya manusia akan siap memberikan yang terbaik bagi negara dengan terciptanya sumber daya manusia yang unggul dan bermutu.

Dengan demikian pemerintah yang Kompetitif akan terbentuk dengan baik, sebagaimana menurut Anggara (2014:218) prinsi layanan dapat dilakukan sebagai berikut :

1. Pemberian jasa/layanan harus bersaing dalam usaha berdasarkan kinerja dan harga

2. Persaingan adalah kekuatan fundemental yang tidak memberikan pilihan lain yang harus dilakukan oleh organisasi public

3. Pelayanan publik dilaksanakan oleh pemerintah tidak bersifat Monopoli tetapi harus bersaing. 
4. Masyarakat dapat memilih playanan yang di sukainya, oleh sebab itu, pelayanan sebaiknya mempunyai alternatil, kompentensi merupakan satu-satunya cara untuk menghermat biaya sekaligus meningkatkan kualitas layanan, dengan kompetesi, banyak pelayanan publik yang dapat di tingkatklan kualitasnya tanpa harus mempebesar biaya.

\section{Daftar Pustaka}

Sedarmayanti. (2016). Manajemen sumber daya manusia reformasi birokrasi dan manajemen pegawai Negeri Sipil. Bandung: PT Refika Aditama.

Sahya Angggara.( 2014). Kebijakan Publik. Bandung : Pustaka Indah.

Surat Edaran Menteri agama Republik Indonesia Nomor: SE. 14 Tahun 2021 Tentang Sistem Kerja Aparatur Sipil Negara (ASN) kementerian agama pada masa pandemi Covid -19 Tahun kedua. 


\title{
KEMANDIRIAN PENYELENGGARA PEMILIHAN PADA MASA PANDEMI COVID-19
}

\author{
Ngimadudin, $\mathrm{MH}^{28}$ \\ STAI Bumi Silampari Lubuklinggau
}

"Indonesia merupakan Negara demokrasi dimana kekuasaan

dari dan untuk rakyat, dalam penyelenggaraan pemilu membutuhkan penyelenggara yang memiliki jiwa mandiri dengan prinsip keterbukaan, partisipatif, objektif, dan akuntabel"

Filosofi tentang tujuan berbangsa dan bernegara di Republik Indonesia tertuang dalam Pembukaan UndangUndang Dasar (UUD) Negara Republik Indonesia (RI) Tahun 1945, pada alinea ke empat yang menyatakan bahwa negara berdiri dengan satu tekad yaitu mensejahterakan kehidupan berbangsa dan bernegara, mencerdaskan kehidupan berbangsa, mencerdaskan kehidupan bernegara serta ikut memelihara ketertiban dunia, yang berdasarkan perdamaian abadi dan keadilan sosial. Oleh karena itu, dengan maksud mencapai tujuan bernegara, negara tersebut dibingkai atas dasar ketuhanan yang maha esa,

28Penulis lahir di Kalasan Yogyakarta, 08 Desember 1972, penulis merupakan Dosen STAI Bumi Silampari Lubuklinggau dalam bidang ilmu Pendidikan Kewarganegaraan, penulis menyelesaikan gelar Sarjana Syariah di IAIN STS Jambi (1997), sedangkan gelar Magister Hukum Tata Negara diselesaikan di Universitas Sriwijaya (2013), dan saat ini sedang menyelesaikan program Doktoral Ilmu Hukum di Universitas Sriwijaya. 
kemanusiaan yang adil dan beradab, persatuan indonesia, kerakyatan yang dipimpin oleh hikmah dalam permusyawaratan perwakilan, dan keadilan sosial bagi semua rakyat Indonesia.

Dalam tahapan pembangunan negara dengan maksud mewujudkan kemakmuran, kecerdasan, keadilan, dan ketertiban, diperlukan cetak biru yang jelas guna mengatur jalannya pembangunan. Perlunya regulasi yang jelas memberikan arah pembangunan yang terukur dan mampu secara tepat mencapai target yang ingin dicapai. Begitu pula dengan masalah pemilu yang belakangan ini terdistorsi oleh kepentingan sementara yang memberikan citra buruk bagi proses pemilu dan penyelenggaranya.

Hingga tahun 2021, Indonesia telah menyelenggarakan pemilu sebanyak dua belas kali, sehingga sudah sepantasnya kita katakan bahwa kegiatan demokrasi kita sudah memasuki usia dewasa. Pada tahun 1955 merupakan Pemilu pertama di mana pemilihan diadakan dengan maksud memilih anggota Dewan Perwakilan Rakyat dan anggota majelis konstituante. Aparatur Sipil Negara (ASN RI), Tentara Nasional Indonesia (TNI) / Kepolisian Republik Indonesia (Polri) diperbolehkan memanfaatkan hak pilihnya tanpa peraturan yang mengikat guna bertabiat netral pada tahun 1955. Bersumber pada Undang-Undang No 7 Tahun 1953 seluruh rakyat dapat menjadi pemilih. Sementara itu, Pemilu yang diadakan pada tahun 1955 dinilai masyarakat sebagai Pemilu yang demokratis serta bermakna. Hal ini didasarkan beberapa hal antara lain; tidak adanya tuduhan rakyat adanya keberpihakan pemerintah; tidak adanya laporan partisipan pemilu yang dituduh bermain mata dengan penyelenggara; tidak terdapat tudingan terhadap penyelenggara pemungutan 
suara (KPPS) ataupun kecurangan yang lain (Kemandirian Penyelenggara Pemilu, n.d.).

Pada Pemilihan umum, pemilihan kepala daerah yang adil dan kredibel, dapat terwujud jika diselenggarakan oleh lembaga khusus yang independen dan diawasi oleh badan yang independen pula. Konstitusi menyatakan bahwa pemilihan dilakukan oleh badan pemerintahan yang independen.

\section{Penyelenggara Pemilihan}

Pemerintah Republik Indonesia (RI), dibawah kepemimpinan Presiden Republik Indonesia, B.J. Habibie memulai pembenahan penerapan pemilu pada tanggal 7 Juni 1999. Salah satu langkah revisi tersebut yakni Komisi Pemilihan Umum memiliki jumlah anggota sebanyak 48 orang perwakilan partai politik serta 5 orang perwakilan pemerintah. Asas pemilu pun ditambahkan selaku wujud revisi serta penyesuaian terhadap tuntutan yang berkembang sehingga menjadi Pemilihan yang langsung, umum, bebas, rahasia, jujur, serta adil. Akumulasi prinsip jujur serta adil diharapkan jadi semangat baru penyelenggara pemilu. Pengawasan pemilu masih diaktifkan dengan nomenklatur diganti jadi Badan Pengawas Pemilu (Bawaslu). Dikala ini jumlah anggota KPU RI yakni tujuh (7) orang serta Bawaslu RI sebanyak lima (5) orang ditambah dengan penyelenggara di tingkat propinsi, kabupaten/kota, tingkat kecamatan sampai tingkat desa.

Amandemen Undang-undang pada tahun 2002, MPR menetapkan asas-asas pemilu serta lembaga penyelenggara pemilu sebagaimana syarat dalam UUD 1945, dimana pada saat sebelum amandemen. Pasal 22 E ayat satu UUD 1945 hasil pergantian berbunyi "Pemilihan umum diselenggarakan secara langsung, umum, bebas, rahasia, 
jujur, serta adil tiap lima tahun sekali", serta Pasal dua puluh dua huruf 'E' ayat lima berbunyi "Pemilihan umum diselenggarakan oleh komisi pemilihan umum yang bersifat nasional, tetap, serta mandiri".

Dengan syarat tersebut, ada kepastian hukum yang jelas serta kokoh terhadap penyelenggara pemilu yang independen dari pemerintah serta tidak bisa diintervensi oleh kekuasaan baik yudikatif, eksekutif maupun legislatif.

Saat ini penyelenggara pemilu di Indonesia terdiri dari Komisi Pemilihan Umum (KPU RI), Badan Pengawas Pemilu (BAWASLU RI) dan didukung oleh Dewan Kehormatan Penyelenggara Pemilu (DKPP RI) sebagai penyelenggara pemilu tunggal [12]. Penyelenggara pemilu, baik KPU, Bawaslu, maupun DKPP dipilih melalui seleksi yang dilakukan oleh Tim Seleksi (Timsel) sesuai dengan tingkat pelaksanaannya. Dalam proses seleksi, diperlukan Timsel yang berintegritas dan memahami seluk beluk pemilu bukan hanya sekedar perpanjangan tangan dari 'orang/partai' tertentu.

Setelah terpilih menjadi anggota KPU. Bawaslu, dan DKPP, dibutuhkan pelatihan sumber daya manusia (SDM) secara berkesinambungan mulai dari pelatihan teknis dan non teknis, bahkan pelatihan etika juga sangat diperlukan mengingat tingkat kebutuhan SDM yang ada. Pelatihan dimaksud bukan hanya sekedar pelatihan berkenaan undang undang pemilu dan aturan yang menyertainya, tetapi juga aspek etika dan tanggungjawab sebagai bagian penyelenggara pemilu.

Persyaratan pengelola pemilu sudah jelas secara administratif. Salah satunya adalah penyelenggara pemilu bukan anggota partai politik minimal lima tahun, mulai dari tingkat pusat (KPU RI), tingkat provinsi (KPU Propinsi), 
tingkat Kabupaten/Kota (KPU Kab/Kota), Panitia Pemungutan Kecamatan (PPK), dan Panitia di tingkat Desa/Kelurahan (PPS) sampai dengan Panitia yang berada di Tempat Pemungutan Suara (TPS). Hanya saja soal independensi semakin sulit untuk diterapkan, misalnya dalam proses pembuatan kebijakan seperti PKPU. Saat ini KPU wajib (terpaksa) menampung 2 komisi DPR tersebut dan harus ditindaklanjuti dan proses antar paripurna membutuhkan waktu yang relatif lama. Dulu hanya wajib berkonsultasi dengan DPR RI. Penyelenggaraan pemilu ke depan sangat kompleks sesuai dengan kondisi dan tingkatannya, apalagi pemilu akan dilaksanakan secara sekaligus mulai dari Pemilihan anggota DPR, anggota DPRD Propinsi, anggota DPRD Kabupaten/Kota, anggota Dewan Perwakilan Daerah (DPD), bahkan pemilihan kepala daerah. Sehingga sangat diperlukan penyelenggara yang independen dan berintegritas sesuai dengan keinginan dan amanah Undang Undang.

Selain tugas melaksanakan pemilu, ada beberapa hal yang harus menjadi perioritas penyelenggara pemilu yakni bagaimana meningkatkan partisipasi pemilu dengan memastikan kehadiran pemilih di TPS (Tempat Pemungutan Suara), menghindari politik uang, meningkat melek politik masyarakat dengan memilih orang yang memang sesuai aspirasi masyarakat.

\section{Kemandirian, Integritas, Good Governance, Clean Governance}

Masyarakat Indonesia digemparkan suatu berita adanya seorang anggota KPU RI, diputuskan bersalah dan diberhentikan sebagai karena melakukan menerima suap dari salah satu calon anggota DPR RI pada Pemilu 2019 yang lalu. 
Bagaimana

menggunakan

sistem

pengendalian/pengawasan internal KPU. mandiri, tidak boleh ada intervensi dari pihak manapun. Semua hal menyangkut penyelenggara pemilu seharusnya diatur secara spesifik jika diperlukan dengan maksud menjaga integritas dan kemandiriannya. Misalnya jika ada pertemuan dengan orang partai tidak boleh hanya satu anggota KPU saja yang ketemu orang partai politik sehingga tidak berujung dengan kemufakatan yang "jahat”.

Kemandirian penyelenggara pemilihan umum dalam perihal seleksi Anggota mulai dari pusat sampai dengan Kabupaten/Kota, dilatarbelakangi oleh terdapatnya ketentuan penyelenggara pemilihan umum yang membuka kesempatan untuk masuknya kader partai politik serta pemerintah dalam keberadaannya selaku penyelenggara pemilu yang bertabiat mandiri, sebagaimana yang telah diatur dalam Undang- Undang No 7 Tahun 2017 tentang Pemilihan Umum (Inilah Undang-Undang Nomor 7 Tahun 2017 Tentang Pemilihan Umum (1), n.d.). Namun, dalam pelaksanaan pemilihan, pemerintah dan partai politik tetap terlibat dalam seleksi pengelola pemilihan umum. Sebenarnya, ketentuan/ketetapan mengenai independensi penyelenggara pemilihan umum telah termaktub dalam Undang-Undang Dasar Negara Republik Indonesia Tahun 1945, sehingga seleksi penyelenggara pemilihan tersebut hendaknya juga pada akhirnya akan memperkuat independensi penyelenggara pemilihan umum itu sendiri.

Prinsip keterbukaan, partisipatif, objektif, dan akuntabel menjadi dasar dengan maksud menjaga tetap terpeliharanya nilai independensi ini. Selanjutnya, syarat calon penyelenggara pemilihan umum adalah tanpa membuka peluang masuknya partai politik dan pemerintah 
dalam keanggotaannya. Sudah saatnya kita semua mendukung terwujudnya pemerintahan yang baik dan bersih dengan menjadi penyelenggara / pengelola pemilu yang mandiri dan berintegritas atau mendapatkan penyelenggara yang berintegritas pada semua tingkatan yang ada.

\section{Daftar Pustaka}

Inilah Undang-Undang Nomor 7 Tahun 2017 tentang Pemilihan Umum (1). (n.d.). Retrieved August 21, 2021, from https://setkab.go.id/inilah-undangundang-nomor-7-tahun-2017-tentang-pemilihanumum-1/

Institusi-DKPP RI. (n.d.). Retrieved August 21, 2021, from https://dkpp.go.id/institusi/

Kemandirian Penyelenggara Pemilu. (n.d.). Retrieved August 18, 2021, from https://news.detik.com/kolom/d4142377/kemandirian-penyelenggara-pemilu 


\section{VAKSINASI DIBUTUHKAN \& AMAN UNTUK KELUARGA}

\section{Filka Khairu Pratama, S.Sos 29 \\ Analis Bina Ketahanan Remaja Perwakilan BKKBN}

"Menumbuhkan kesadaran pentingnya vaksinasi untuk mempertebal imun dan keamanan keluarga"

Sejak kemunculan kasus pertamanya di Provinsi Wuhan
sekitar awal tahun 2020 lalu, virus covid 19 telah banyak memakan korban jiwa diberbagai negara. Sehingga, menyebarnya virus covid 19 serentak diseluruh dunia sudah menaikkan level status virus tersebut menjadi pandemi. Kalau kita lihat informasi dari dw.com, PBB pada Kamis 7 Oktober 2020 lalu menjelaskan, sekitar dua juta bayi yang baru lahir meninggal tiap tahunnya. Dalam kategori yang lain, setidaknya satu bayi wafat tiap 16 detik di seluruh dunia. Sehingga, PBB pun memperingatkan bahwa pandemi COVID-19 berpotensi menambah $200 \mathrm{ribu}$ kematian yang terjadi pada bayi.

Laporan UNICEF bersama Organisasi Kesehatan Dunia (WHO), dan Grup Bank Dunia (World Bank Group) menyebutkan sekitar 84 persen kematian bayi baru lahir terjadi pada negara-negara yang memiliki penghasilan rendah dan menengah. Menurut mereka, besarnya kasus

${ }^{29}$ Penulis lahir di Sikakap, 19 Agustus 1995. Penulis merupakan analis bina ketahanan remaja perwakilan BKKBN Sumatera Barat. Penulis menyelesaikan gelar sarjana sosiologi di Universitas Andalas (2013). 
kematian bayi yang dilaporkan disebabkan karena kualitas layanan kesehatan yang buruk, hingga minimnya investasi dalam peralatan dan pelatihan bidan guna menghasilkan infrastruktur kesehatan yang berkualitas. Nampaknya, pandemi pun kembali akan menjadi ancaman serius bagi bayi baru lahir diseluruh dunia.

Sementara itu, Kompas.com memberitakan bahwa, Kepala BKKBN Hasto Wardoyo mengatakan, angka kematian ibu hamil selama musim pandemi Covid-19 selama awal 2021 di dalam negeri sangat tinggi dan mengkhawatirkan. Hal ini dipertegas juga berdasarkan data yang dikutip dari Perkumpulan Obstetri dan Ginekologi Indonesia (POGI) yang tercatat hingga April 2021 hasilnya menunjukkan, sejumlah 536 ibu hamil di seluruh Indonesia terpapar Covid-19, dengan pembagian 16 orang meninggal atau diperkirakan setiap 1.000 ibu hamil, 32 diantaranya meninggal.

Lebih lanjut Kepala BKKBN menambahkan, dalam kondisi normal tidak ada pandemi, rata-rata angka kematian ibu adalah setiap 1.000 orang ibu hamil kira-kira ada 3 yang meninggal. Jadi jumlah kematian ibu hamil saat pandemi ini sangat tinggi (mencapai) 10 kali lipatnya.

Hal ini juga didukung oleh pernyataan Wakil Ketua Umum Pengurus Besar Ikatan Dokter Indonesia (PB IDI), Slamet Budiarto di Jakarta, Sabtu (21/8/2021) yang dikutip melalui Kompas.com, juga menyampaikan risiko kematian pada ibu hamil akibat Covid-19 amat besar. Upaya untuk menekan angka kematian ibu hamil dirasa sangat mendesak. Untuk itu, sangat diperlukan program vaksinasi yang terus diperluas hingga keseluruh lapisan masyarakat.

Melihat situasi tersebut, saat ini pemerintah telah mengeluarkan ajakan untuk kita semua agar berkenan 
melakukan vaksinasi. Menurut banyak praktisi kesehatan, vaksinasi bisa dilakukan dan aman untuk ibu hamil yang usia kehamilannya lebih dari tiga bulan dan kurang dari tujuh bulan. Selanjutnya kepada anak usia diatas 12 tahun, boleh divaksin. Begitupun orang dewasa dan lansia yang semua kategorinya harus memenuhi standar kesehatan. Pemerintah telah menyatakan program vaksinasi sebagai upaya bersama dalam meminimalisir dampak pandemi bagi tubuh seseorang, sehingga tercipta kekebalan kelompok. Untuk itu dalam hal ini, pemerintah melalui Kementrian Kesehatan dan banyak pakar meyakini bahwa :

Pertama, program vaksinasi Covid-19 turut mengurangi dampak yang ditimbulkan, seandainya kita tertular Covid-19. Awalnya, vaksinasi diadakan bukan hanya bertujuan untuk memutus rantai penularan penyakit dan menghentikan wabah, namun juga dalam jangka panjang meminimalisir atau bahkan memusnahkan penyakit itu sendiri. Tujuan vaksinasi ini kiranya juga digunakan untuk penyakit Covid-19 akibat virus corona. Dengan mengajak orang terdekat untuk ikut vaksin, setidaknya kita mencegah dampak yang lebih parah seandainya orang tersebut terkena covid -19 kedepannya.

Kedua, ikut vaksin turut melindungi orang lain. Jika jangkauan vaksinasi tinggi dan merata di suatu daerah, maka akan terbentuk kekebalan kelompok (herd immunity) juga meningkat. Setelah kekebalan kelompok meningkat, maka kondusifitas kegiatan dimasyarakat bisa lebih cepat pulih seperti sedia kala. Masyarakat bisa beraktifitas, tanpa perlu terlalu risau dengan virus covid-19. Mengikuti vaksinasi juga berarti membuktikan tingkat solidaritas terhadap sesama. Jadi dengan ikut vaksinasi, kita setidaknya sudah berupaya melindungi anggota kelompok dengan 
meminimalisir penularan virus dari tubuh kita ke orang lain. Maupun meminimalisir penularan virus dari orang lain dan lingkungan yang akan menyerang sistem kekebalan tubuh kita. Jadi setidaknya sama-sama melindungi.

Ketiga, ikut vaksin adalah upaya bersama menghentikan penyebaran Covid-19. Pada dasarnya, program vaksinasi diselenggarakan bukan hanya bertujuan untuk memutus mata rantai penularan penyakit dan menghentikan wabah, tetapi juga dampak jangka panjangnya mengeliminasi dan bahkan memusnahkan penyakit tersebut.

Keempat, ikut vaksin akan membantu melindungi generasi selanjutnya. Mengutip Mayo Clinic dalam Kompas.com, manfaat vaksin Covid-19 salah satunya adalah mencegah virus corona tambah meluas dan bereplikasi menjadi jenis baru yang mungkin lebih berbahaya. Sejak dahulu ada banyak penyakit yang disebabkan oleh virus bisa menyebabkan banyak angka kematian. Setidaknya dengan adanya upaya vaksinasi penyakit dapat dikendalikan secara bersama. Setidaknya kita adalah generasi yang hidup dari perjuangan vaksinasi generasi yang sebelumnya.

Ajakan untuk mengikuti vaksinasi saat ini telah gencar dilakukan oleh pemerintah dan berbagai pihak. Vaksin yang tersedia ada Sinovac, AstraZeneca, Sinopharm, Moderna, dan Pfizer. Selain itu, urgensi mengikuti vaksin juga untuk mengikuti anjuran dari pemerintah sebagai pemimpin yang diamanahkan rakyat. Agama pun menginstruksikan agar kita semua mengikuti anjuran pemerintah, selama itu tidak bertentangan dengan agama dan mendatangkan manfaat. Kita sebagai masyarakat dinilai wajib hukumnya mematuhi 
dan melaksanakan anjuran pemerintah yang notabene sebagai pemimpin kita.

Saat ini, agar semua anggota keluarga dapat menerima layanan vaksin, sudah tersedia vaksin untuk ibu hamil diatas 3 bulan dan kurang dari 7 bulan kehamilan, anak diatas 7 tahun dan lansia yang memenuhi persyaratan dari tenaga kesehatan. Upaya vaksinasi juga akan meningkatkan ketahanan anggota keluarga pada era pandemi. Vaksin yang telah diuji banyak pakar, dan diakui pemerintah serta Majelis Ulama Indonesia hendaknya, tidak diragukan lagi sebagai sebuah wadah untuk meminimalisir dampak buruk dari pandemi. Mari ikut vaksin, vaksin aman untuk keluarga dan lingkungan kita.

\section{Daftar Pustaka}

https://www.dw.com/id/pbb-akibat-covid19-lebih-dari-2juta-bayi-meninggal/a-55196850 diunggah 25 Agustus 2021

https://www.kompas.id/baca/ilmu-pengetahuan-

teknologi/2021/08/22/angka-kematian-covid-19masih-tinggi/ diunggah 25 Agustus 2021

https://www.kompas.com/tren/read/2021/02/25/11350

0165/apa-saja-syarat-lansia-yang-bisa-

mendapatkan-vaksin-covid-19- diunggah 25

Agustus 2021

https://covid19.go.id/edukasi/masyarakat-umum/vaksincovid-19-aman-untuk-ibu-hamil diunggah 25 Agustus 2021

https://health.detik.com/berita-detikhealth/d-

5635311/usia-berapa-bisa-vaksin-covid-simak-disini diunggah 25 Agustus 2021

https://www.kompas.id/baca/metro/2021/08/19/dalamtiga-bulan-36-juta-ibu-hamil-mendapat-vaksin/ 


\title{
CYBERSPACE DALAM KOMUNIKASI KESEHATAN DI ERA PANDEMI
}

\author{
Welda Yulia, S.Tr.Keb ${ }^{30}$ \\ BKKBN Provinsi Sumatera Barat
}

"Promosi kesehatan pada era digital dikembangkan dengan metode nonkonvensional sangat dibutuhkan dalam menghadapi pandemi covid 19 yang dapat menjangkau berbagai khalayak masyarakat"

Komunikasi kesehatan dapat diartikan sebagai upaya penggunaan prinsip dan metode komunikasi secara sistemastis untuk memengaruhi secara positif perilaku kesehatan khalayak. Komunikasi dimaksud dilakukan secara interpersonal, kelompok maupun massa (Notoatmodjo 2007). Komunikasi kesehatan memiliki tujuan dalam hal memicu berubahnya prilaku kesehatan masyarakat ke arah yang lebih baik, kemudian berdampak pada peningkatan derajat kesehatan masyarakat. Pemanfaatan komunikasi kesehatan memang harus selalu ditingkatkan demi menyukseskan kesehatan masyarakat,. Ilmu komunikasi memiliki peranan yang penting pada

\footnotetext{
30 Penulis lahir di Lubuk Tarok, 15 Juli 1989. Penulis menyelesaikan pendidikan D3 Kebidanan pada Poltekkes Kemenkes RI Padang tahun 2010, D4 Kebidanan pada STIKes Fort De Kock Bukittinggi. Saat ini penulis sedang mengikuti Tugas Belajar S2 Ilmu Komunikasi pada Universitas Andalas Padang dengan beasiswa KOMINFO RI Tahun 2020. Penulis bekerja sebagai fungsional Penyuluh Keluarga Berencana pada Perwakilan BKKBN Provinsi Sumatera Barat.
} 
semua analisis mengenai upaya meningkatkan kualitas hidup manusia, terutama strategi komunikasi dalam penyebarluasan informasi-informasi kesehatan (Notoatmodjo 2007).

Bahasan dalam komunikasi kesehatan mencakup tentang preventif, promosi kesehatan, kebijaksanaan pemeliharaan. kesehatan, aturan usaha pada sektor kesehatan kesehatan. Pada hal ini komunikasi kesehatan selalu mempertimbangkan ilmu pengetahuan dan etika (Liliweri 2007). Komunikasi. kesehatan mencakup pemanfaatan teknik komunikasi yang digunakan dalam menyampaikkan serta mengubah kognitif, afektif dan psikomotor masyarakat terkait kesehatan individunya. Perihal ini dapat terlihat melalui promosi kesehatan yang berupaya untuk mengubah dan mendorong perilaku. sehat, menumbuhkan kesadaran, dan perubahan prilaku ke arah yang positif.

Dalam situasi pandemi sangat penting penyampaian informasi dalam mengedukasi kesehatan melalui. promosi kesehatan. Ada beberapa hal yang menjadi pembahasan promosi kesehatan pada masa pandemi diantaranya meliputi Germas masa pandemi, PHBS, trik pemeliharaan kesehatan, serta kuratif. Pemanfaatan media komunikasi/teknologi digital pada masa pandemi akan memudahkan kita dalam promosi kesehatan dalam hal menjangkau khalayak sebagai sasaran program kesehatan. Contohnya banyaknya pemanfaatan baliho, iklan, kampanye berisikan pesan mematuhi protokol kesehatan era pandemi.

Penyuluh kesehatan dan jajaran memiliki peranan penting dalam mengedukasi keluarga dan masyarakat saat ini. Sistem penyuluhan kesehatan/promosi ksehatan dapat dilakukan dengan menggunakan media konvensional 
seperti tatap muka lansung, melalui.radio,.media. cetak dan lain- lain. Selain itu promosi kesehatan ini dapat dilakukan dengan cara non konvensional sperti melalui dunia maya (cyberspace). Promosi kesehatan dengan cara non konvensional melalui dunia maya ini dianggap cocok dengan situasi industri komunikasi 4.0 dan salah satunya mampu meminimalkan resiko penularan Covid 19 sesuai situasi saat ini. Dengan meminimalkan promosi/penyuluhan tatap muka dapat mengurangi resiko penyebaran Covid - 19.

Pada dasarnya promosi kesehatan merupakan penerapan komunikasi massa. Komunikasi massa dapat diartikan sebagai upaya penyebaran informasi dan pesan pesan melalui media massa (media cetak dan elektronik). Sementara massa sendiri lebih diartikan sebagai receiver (Purwoastuti 2015). Hal ini dapat diasumsikan bahwa pembentukan sikap dan prilaku receiver dipengaruhi oleh media massa (Nurudin 2004).

Pada zaman sekarang, peradaban manusia sudah melalui berbagai macam era, salah satunya yaitu era komunikasi. Era komunikasi adalah sebuah era di mana aktivitas informasi mendominasi kegiatan ekonomi dan kehidupan masyarakat. Perubahan ini menunjukan bahwa perekonomian di berbagai Negara, yang tadinya berlandaskan pada sektor industri, kini bergeser ke sektor informasi. Masyarakat sudah mendapatkan informasi dan mampu mencari informasi sendiri melalui yang namanya cyberspace (Elvinaro 2004)

McLuhan berpendapat bahwa teknologi media telah melahirkan resolusi dalam masyarakat karena efek ketergantungan teknologi tersebut. Pendapat McLuhan ini menjelaskan bahwa terdapat hubungan yang erat antara 
teknologi, media dan masyarakat. Eksistensi kehidupan manuasia saat ini ditentukan juga oleh peranan teknologi dan media. Cara berpikir dan berprilaku manusia ditentukan oleh perkembangan teknologi. Bahkan teknologi akhirnya mampu menggiring manusia menyesuaikan diri dengan setiap perkembangan teknologi, termasuk teknologi informasi melalui cyberspace (Nurudin 2007).

Pada web resmi Kementrian Kesehatan Republik Indonesi dapat dilihat pada tanggal 3 Maret 2020 terjadi peningkatan kunjungan website sebanyak $300 \%$ dari sebelumnya dengan rata - rata pengunjung $3.500-4.500$ per hari. Sementara pada tayangan meningkat $400 \%$, dengan rata - rata 9.000 tayangan per hari. Kunjungan dan tayangan tersebut melalui Instagram, Facebook dan Twitter (Kemenkes RI 2020). Hal inilah yang menjadi peluang bagi penyuluh kesehatan serta memanfaatkan dalam melakukan promosi kesehatan dengan menggunakan cyberspace. Selain itu juga berpeluang dalam memutus penularan Covid-19.

\section{Defenisi Komunikasi Kesehatan}

Notoatmodjo (2007) berpendapat bahwa komunikasi kesehatan dianggap sebagai upaya dalam mempengaruhi prilaku kehatan masyarakat ke arah yang lebih baik secara sistematis. Upaya tersebut dilakukan dengan berbagai bentuk dan metode komunikasi diantaranya komunikasi antar pribadi, kelompok dan massa. Informasi yang termasuk dalam komunikasi kesehatan yaitu tentang preventif, promosi kesehatan, kebijakan pemeliharaan.kesehatan, ketentuan dalam usaha bidang kesehatan, yang sejauh mungkin mampu memberikan perubahan pada kualitas individu dalam masyarakat dengan pertimbangan aspek keilmuan dan dan kode etik. 


\section{Penggunaan Cyberspace dalam Komunikasi Kesehatan (Promosi Kesehatan)}

Perubahan terbesar pada bidang komunikasi yaitu aplikasi teori komunikasi pada media baru dengan mengembangkan komunikasi dunia maya (Severin and James W. Tankard 2009). Seluruh tatanan komunikasi memanfaatkan dunia maya dalam aplikasi komunikasinya, tidak terkecuali komunikasi kesehatan. Dunia.maya adalah istilah komprhensif untuk website, internet, forum diskusi/ ngobrol, multi-player interaktif, bahkan email (Severin and James W. Tankard 2009). Menurut Kaplan \& Haenlein (2010), arti kata dunia maya yaitu bentuk kelompok aplikasi menggunakan jaringan internet yang mengkontruksi pandangan serta terjadinya pertukaran pesan dan informasi. Dunia maya yang dimanfaatkan manusia saat ini disebut juga dengan media sosial (social media).

Berdasarkan riset yang dilakukan oleh Kemankes RI Tahun 2018 dinyatakan penyebaran informasi kesehatan akhir-akhir ini sangat tepat sasaran jika menggunakan menggunakan. Karena khalayak media sosial berasal dari berbagai kelas. Begitu juga halnya dengan informasi yang kontra juga cepat tersebar melalui media ini. Kelebihan dari media sosial ini adalah dari segi jangkauannya yang luas dan cepat sehingga banyak digandrungi oleh para penyuluh kesehatan. Namun keberadaan media sosial juga menjadi bumerang bagi khalayak dan dapat diibaratkan sebagai pisau yang bermata dua. Baik buruk informasi dapat disebar melalui media sosial ini. Jika sudah diluncurkan ke media sosial dan dibaca khalayak maka tidak mudah untuk ditarik atau diralat. (Laksono 2018). 


\section{Urgensi pemanfaatan cyberspace dalam promosi kesehatan}

Dari literartur yang didapatkan ada beberapa dasar sehingga dianggap urgensinya pemanfaatn cyberspace ini dalam promosi kesehatan yaitu sebagai berikut : menurut $\mathrm{C}$. Ortega dan Navas (2017) pemanfaatan teknologi berupa media sosial dapat memicu peningkatan pengetahuan masyarakat tentang preventif penyakit, pemanfaatan akses kesehatan, prilaku patuh terhadap pengobatan dan partisipasi dalam menentukan keputusan kesehatannya (Ortega and Navas 2017). Kemudian dengan penggunaan media dunia maya mampu meningkatkan social suppport serta berbagi dukungan dengan orang lain sehingga masyarakat dengan sadar secara spontan berbagi hal yang baik sekaitan dengan perubahan prilaku untuk menjadi sehat yang dialaminya (Linda J. Bergsma 2004).

Berikutnya pemanfaatan cyberspace sebagai media promosi kesehatan mampu menwujudkan peningkatan akses masyarakat terhadap pesan kesehatan dan $\mathrm{m}$ pengalaman positifnya (Bacigalupe 2011), dengan arti kata melalui dunia maya atau media sosial ini mampu saling melengkapi promosi kesehatan metode konvensional yang telah dilakukan selama ini.

Lalu dari segi komponen dunia maya atau media sosial ini lebih unggul dalam hal jangkauan dan interaktivitasnya yang luas (Korda and Itani 2013). Selain itu menurut Melzner (2014), promosi kesehatan menggunakan cyberspace ini dapat diakses di tempat kerja terutama tentang kesehatan kerja karyawan (Melzner and Al 2014).

Berdasarkan hasil riset dijelaskan juga bahwa ditemukan hal menarik dalam penggunaan social media dalam upaya dalam mencegah penyakit seperti upaya 
berhenti merokok melalui situs kesehatan dan twitter (Skinner and Et.al 2006). Kemudian peningkatan pengetahuan remaja tentang kesehatan reproduksi melalui penggunaan media sosial sebagai sumber informasi (Rider and Et.al 2016). Lalu pada penelitian Surya Wibowo tahun 2017 mendapatkan hasil penelitian memang ada pengaruh promosi kesehatan dengan cara mengunggah video pada media sosial terhadap pengetahuan pengguna MSG pada ibu rumah tangga (Wibowo and Suryani 2017).

Selanjutnya berdasarkan riset juga dikatakan bahwa situs jejaring sosial lainnya yang banyak dikunjungi adalah web kesehatan, facebook sebagai tempat pencarian informasi kesehatan bagi masyarakat (A. Andrizal and A.Arif 2017).

Berikutnya melalui media online kesehatan komunitas klinik rumah sakit berhasil meningkatkan citra rumah sakit dengan cara ini (Kristopher and Reicher 2016). Selain itu sesuai penelitian yang dilakukan Firman Tahun 2016 dijelaskan juga bahwa PRO RS Advent Bandung juga sudah menggunakan aktivitas Cyber ini dalam membentuk opini dan sikap publik terhadap RS (Irwansyah and Yuliati 2016).

Dari seluruh literatur yang ditemukan bahwa dengan menggunakan cyberspace dalam melakukan promosi kesehatan dapat berkontribusi positif terhadap tujuan dari promosi kesehatan itu dilakukan. Selain itu penggunaan cyberspace ini dapat melengkapi dan menyempurnakan promosi kesehatan konvensional yang sudah dilakukan sebelumnnya. Oleh karena itu sebagai tenaga profesional bidang kesehatan diharapkan mampu juga mengkolaborasikan metode promosi kesehatan konvensional dan non konvensional, dengan cara mengitegrasikan promosi kesehatan dengan cyberspace. 


\section{Jenis Cyberspace yang Digunakan Selama Ini.}

Era digital saat ini yang dikenal dengan era 4.0 menjadikan masyarakat semakin peka terhadap perkembangan teknologi komunikasi. Termasuk dalam hal pencarian informasi kesehatan bagi masyarakat sudah menggunakan dunia maya sebagai sumber informasinya. Situs web pada saat ini dianggap ampuh dalam menyebarkan informasi dan mendukung promosi kesahatan. Semua itu dapat diakses secara online seperti youtube, facebook, twitter, blog dan lain - lain. Penjabaran mengenai media tersebut terlihat pada tabel 1 sebagai berikut

Tabel 1. Karakteristik Jenis Cyberspace yang Digunakan dalam Promosi Kesehatan.

\begin{tabular}{|c|c|c|}
\hline $\begin{array}{c}\text { Jenis } \\
\text { Cyberspace }\end{array}$ & Karakteristik & Ket \\
\hline Youtube & $\begin{array}{l}\text { 1. Dilihat oleh banyak orang ( lebih dari } 100 \\
\text { juta video dilihat/ hari) } \\
\text { 2. Youtube mempuyai kekuatan dalam } \\
\text { mempengaruhi pribadi dalam masyarakat } \\
\text { dalam mengambil keputusan sekaitan } \\
\text { dengan kesehatan (Vance and Et.al 2008). }\end{array}$ & \\
\hline Facebook & $\begin{array}{l}\text { 1. Digunakan jutaan orang per hari untuk } \\
\text { terlibat dan saling berinteraksi satu sama } \\
\text { lainnya. } \\
\text { 2. } \begin{array}{l}\text { Media ini menyediakan cara lansung dan } \\
\text { privacy dqalam menyampaikan informasi - }\end{array} \\
\text { informasi. } \\
\text { 3. Facebook banyak digunakan oleh khalayak } \\
\text { saat ini sehingga menjadi media sosial yang } \\
\text { paling populer diantara yang lainnya. } \\
\text { 4. Pada facebook terjadi hubungan positif dan } \\
\text { timbal balik antara sesama pencari } \\
\text { informasi (Oh and et.al 2013). }\end{array}$ & \\
\hline
\end{tabular}




\begin{tabular}{|c|c|}
\hline Twitter & $\begin{array}{ll}\text { 1. } & \text { Twitter merupakan situs mikroblog paling } \\
\text { populer di Amerika Serikat. } \\
\text { 2. Jangkauan sangat tinggi di kalangan } \\
\text { generasi muda. } \\
\text { 3. Pengiriman pesan singkat dibatasi } 140 \\
\text { karakter sehingga memudahkan pengguna } \\
\text { merespon secara cepat dan mudah. } \\
\text { 4. Keaktifan pengguna twitter lebih dominan } \\
\text { dalam hal menerima, mengirim maupun } \\
\text { mengirim ulang pesan atau informasi (CDC } \\
\text { 2011). } \\
\text { 5asaran pengguna adalah pelajar, } \\
\text { mahasiswa, guru/ dosen kesehatan, para } \\
\text { profesional kesehatan (Fettrow 2016). }\end{array}$ \\
\hline Blog & $\begin{array}{l}\text { 1. Blog dapat diartikan sebagai wujud tulisan } \\
\text { yang ada pada aplikasi web. } \\
\text { 2. web ini dapat digunakan dan ditelusuri oleh } \\
\text { semua orang yang mengakses berdasarkan } \\
\text { keperluan dan kebutuhan serta tujuan dari } \\
\text { para blogger (CDC 2011). }\end{array}$ \\
\hline
\end{tabular}

Dari beberapa karakteristik jenis cyberspace yang digunakan dalam promosi kesehatan di atas dapat kita pilah jenis yang sesuai dengan kondisi dan situasi yang kita alami. Setiap tenaga profesional kesehatan sebaiknya mampu mengkolaborasikan promosi kesehatan dengan salah satu jenis cyberspace yang mempunyai ciri khas/ karakteristik yang unik masing-masing jenis tersebut.

\section{Kelemahan Penggunaan Cyberspace dalam Promosi Kesehatan}

Berikutnya ada beberapa kelemahan dari penggunaan cyberspace dalam promosi kesehatan berdasarkan literatur yang telaah. Kelemahan - kelemahan tersebut adalah sebagai berikut: 
Pasif nya pencari informasi pada negara berkembang, hal ini menyebabkan informasi yang dipublish tidak diakses oleh masyarakat, termasuk kurangnya akses mayarakat terkait dengan blankspot (Benigeri and Pluye 2010)

Informasi yang disebarkan pada web beresiko tidak akurat dan informasi tidak berimbang. Hal ini disebabkan semua orang yang bisa mengakses internet mempunyai hak untuk menyebarkan informasi. Terkadang orang yang tidak kompeten pada bidang kesehatan juga menyebarkan informasi (Jacobs and Et.al 2017). Dalam hal ini sangat perlu literasi media bagi masyarakat.

Informasi pada dunia maya terdapat beberapa yang teridentifikasi berita palsu. Sehingga ini berdampak negatif terhadap perilaku masyarakat termasuk juga akan berdampak terhadap hasil kesehatan yang buruk (Benigeri and Pluye 2010). Menyikapi hal ini diperlukan penjelasan dari pihak berwenang terhadap konten medianya sehingga masyarakat dapat berita yang benar - benar bermanfaat.

Minimnya kemampuan dari tenaga profesional kesehatan dalam mengoperasikan dunia maya ( media sosial) sebagai penyebar informasi (Hason and Et.al 2011). Selain itu sesuai dengan penelitian Firman tahun 2016, rendahnya kualitas SDM tenaga PRO RS Advent Bandung juga merupakan kelemahan penggunaan cyberspace dalam dunia kesehatan (Irwansyah and Yuliati 2016)

Rendahnya interaktif antara tenaga profesional dan pencari informasi, masyarakat tidak tertarik mengakses situs tersebut, sehingga promosi kesehatan menggunakan dunia maya tidak berlanjut dan berkesinambungan (Boyington and Et.al 2003). 
Dari beberapa kelemahan penggunaan cyberspace dalam promosi kesehatan di atas, peneliti dapat menyimpulkan bahwa kelemahan yang terkait dengan SDM tenaga profesional kesehatan perlu peningkatan SDMnya melalui upaya pelatihan, TOT dan lain sebagainya. Selanjutnya untuk mengcounter isu palsu dan tidak akurat sangat diperlukan penanaman literasi media bagi masyarakat saat melakukan promosi kesehatan konvensional. Selain itu untuk menumbuhkan ketertarikan masyarakat untuk mengakses informasi kesehatan tersebut diperlukan pendekatan khalayak masing - masing dengan menyajikan konten menarik bagi masyarakat. Dalam hal ini sangat dituntut keahlian dan kecakapan tenaga profesional kesehatan dalam mengkolaborasikan promosi kesehatan konvensional dan mengintegrasikan media sosial (dunia maya) dalam promosi kesehatan. 


\title{
HUKUM DAN KEMANUSIAAN DI MASA PANDEMI COVID-19
}

\author{
Syaiful Anwar, S.Ag., MH ${ }^{31}$ \\ STAI Bumi Silampari Lubuklinggau
}

"Setiap warga negara berhak untuk mendapatkan kesehatan, pemerintahpun mengupayakan dengan diberlakukannya vaksinasi gratis kepada seluruh lapisan masyarakat, apakah masih ada ketimpangan antara hukum dan kemanusiaan?"

$\mathrm{M}$ asa pandemi saat ini, sudah mengobrak-abrik tatanan kehidupan berbangsa dan bernegara kita saat itu. Tentu saja membuat kondisi bangsa kita, bangsa Indonesia, mengalami musibah besar dalam dekade 10 tahun terakhir. Secara aspek legal, saat ini kita sedang darurat bencana pandemi, setiap kurang dari 10 menit terdapat orang meninggal karena Covid-19 (Guritno, 2021). Secara ekonomi dan sosial banyak yang mengalami penurunan pendapatan, peluang kerja juga menjadi sedikit sebagai akibat terbatasnya ruang gerak beraktivitas sehingga meningkatkan jumlah pengangguran. Tak kurang,

\footnotetext{
31Penulis lahir di desa lubuk ngin kecamatan selangit kab Musi Rawas provinsi Sumatera Selatan, 20 September 1977, penulis merupakan Dosen di STAI Bumi Silampari Lubuklinggau dalam bidang ilmu hukum Islam, perbandingan ilmu hukum madzhab, penulis menyelesaikan gelar sarjana di IAIN Curup (2000), sedangkan gelar Megister Hukum Keluarga Islam diselesaikan di IAIN Curup (2020), dan saat ini sedang menyelesaikan program Doktor Ilmu Syariah di Universitas Islam Negeri Sultan Thaha Saifuddin Jambi.
} 
penderitaan terjadi hampir pada semua sektor swasta yang memang menghidupi dirinya sendiri.

Sebenarnya, vaksin adalah instrumen utama dan penting dalam melindungi warga negara, hal ini berdasarkan pada ilmu pengetahuan dan tehnologi yang ada. Tindakan pemerintah melalui kepemimpinan Presiden Jokowi dalam hal pemberian vaksin gratis bagi masyarakat saat ini dipandang sangat tepat. Presiden telah menyerukan kepada masyarakat melalui Peraturan Menteri Kesehatan (Permenkes RI) Nomor 10 Tahun 2021 bahwa vaksin diberikan tanpa biaya/gratis bagi seluruh masyarakat Indonesia (Peraturan Menteri Kesehatan Republik Indonesia Nomor 10 Tahun 2021 - Regulasi / Covid19.Go.Id, n.d.).

Hanya saja, ditengah kondisi tata kelola penanganan pandemi yang masih terus diperbaiki dalam menghadapi pandemi, sangat disayangkan Menteri Kesehatan Republik Indonesia (Menkes) RI sebagai pembantu Presiden telah mengeluarkan Peraturan Menteri Kesehatan Republik Indonesia (Permenkes RI) Nomor Sembilan belas tahun 2021 yang menjadikan vaksin sebagai komoditi jual beli dan privilese. Kebijakan ini bertentangan dengan semangat Peraturan Menteri Kesehatan Republik Indonesia (Permenkes RI) Nomor Sepuluh tahun 2021 yang sebelumnya menyatakan bahwa vaksinasi tidak akan dibebankan ke pengguna melainkan dibebankan kepada perusahaan sebagaimana lazimnya jaminan kesehatan lainnya.

Peraturan Menteri Kesehatan Republik Indonesia (Permenkes RI) Nomor Delapan Belas tahun 2021 juncto Peraturan Menteri Kesehatan Nomor 19 Tahun 2021 berlawanan dengan hak warga negara Indonesia atas pemenuhan kesehatan di masa pandemi. 
Warga negara Indonesia saat ini mengalami beban sosial dan ekonomi yang berat, sehingga jika pembiayaan vaksin dibuat menjadi mandiri oleh masing-masing warga negara, maka dapat dipastikan akan memberatkan masyarakat secara umum. Sehingga sudah sangat tepat pemerintah mengratiskan vaksinasi untuk semua lapisan masyarakat.

\section{Dasar Hukum}

Secara konstitusional, salah satu yang menjadi hak asasi manusia (HAM) yaitu hak atas kesehatan, dan hal ini merupakan kewajiban pemerintah dalam hal pemenuhannya. Undang-Undang Dasar (UUD) Negara Republik Indonesia menegaskan bahwa hak atas kesehatan merupakan hak asasi manusia (UNDANG UNDANG REPUBLIK INDONESIA, n.d.) sebagaimana terdapat dalam Pasal Dua Puluh Delapan huruf ' $\mathrm{H}$ ' ayat satu menyatakan "Setiap orang berhak hidup sejahtera lahir dan batin, bertempat tinggal, dan mendapatkan lingkungan hidup yang baik dan sehat serta berhak memperoleh pelayanan kesehatan".

Dalam Pasal Dua Puluh Lima Deklarasi Universal (HAM) Hak Asasi Manusia berbunyi "Setiap orang berhak atas taraf kehidupan yang memadai untuk kesehatan dan kesejahteraan dirinya sendiri dan keluarganya, termasuk hak atas pangan, sandang, papan, dan pelayanan kesehatan, pelayanan sosial yang diperlukan, serta hak atas keamanan pada saat menganggur, sakit, cacat, ditinggalkan oleh pasangannya, lanjut usia, atau keadaan-keadaan lain yang mengakibatkan merosotnya taraf kehidupan yang terjadi diluar kekuasaannya".

Pada pasal Dua Belas konvensi Internasional tentang Hak Sosial, Ekonomi, dan Budaya, telah diratifikasi oleh 
Pemerintah Indonesia dengan Undang-Undang (UU) Republik Indonesia Nomor sebelas 2005, pada pasal satu berbunyi "Negara-negara Peserta Perjanjian ini mengakui hak setiap orang untuk menikmati standar tertinggi yang dapat dicapai untuk kesehatan jasmani dan rohani". Pasal dua "Langkah-langkah yang diambil oleh Negara-negara Peserta Perjanjian ini untuk mencapai pelaksanaan sepenuhnya atas hak ini termasuk Pencegahan, perawatan dan pengawasan terhadap penyakit epidemik, endemik, penyakit karena pekerjaan dan penyakit lainnya".

Undang-Undang (UU) Republik Indonesia (RI) Nomor tiga puluh enam 2009 tentang Kesehatan menegaskan pada pasal empat berbunyi “Setiap orang berhak atas kesehatan'. Pada Pasal lima ayat satu berbunyi " Setiap orang mempunyai hak yang sama dalam memperoleh akses atas sumber daya di bidang kesehatan", pada pasal dua "Setiap orang mempunyai hak dalam memperoleh pelayanan kesehatan yang aman, bermutu, dan terjangkau', pada pasal tiga "Setiap orang berhak secara mandiri dan bertanggung jawab menentukan sendiri pelayanan kesehatan yang diperlukan bagi dirinya", Pasal lima belas berbunyi "Pemerintah bertanggung jawab atas ketersediaan lingkungan, tatanan, fasilitas kesehatan baik fisik maupun sosial bagi masyarakat untuk mencapai derajat kesehatan yang setinggi-tingginya", pada Pasal enam belas berbunyi "Pemerintah bertanggung jawab atas ketersediaan sumber daya di bidang kesehatan yang adil dan merata bagi seluruh masyarakat untuk memperoleh derajat kesehatan yang setinggi-tingginya".

Undang-Undang (UU) Republik Indonesia (RI) Nomor Tiga Puluh Sembilan 1999 tentang HAM (Hak Asasi Manusia), pada pasal sembilan berbunyi "Setiap orang 
berhak untuk hidup, mempertahankan hidup dan meningkatkan taraf kehidupannya"; pasal delapan berbunyi "Perlindungan, pemajuan, penegakan, dan pemenuhan hak asasi manusia terutama menjadi tanggung jawab Pemerintah"

Dengan demikian, seluruh acuan diatas menegaskan bahwa kesehatan adalah hak masyarakat selaku warga negara. Kewajiban dalam pemenuhan layanan kesehatan demi tercapainya derajat tertinggi kesehatan adalah wewenang Pemerintah Republik Indonesia yang secara teknis pelaksanaan dibawah Kementrian Kesehatan Republik Indonesia sebagai penyelenggara negara.

Majelis Ulama Indonesia (MUI) sebagai lembaga resmi ummat islam pun telah mengeluarkan beberapa fatwa terkait dengan pandemi covid 19 I ini beserta fatwa boleh atau tidaknya vaksinasi. Saat ini, terpenting adalah bagaimana memberikan pengertian/pemahaman kepada masyarakat agar senatiasa untuk mematuhi protokol kesehatan serta menyadari pentingnya untuk melaksanakan anjuran pemerintah dengan mengikuti vaksinasi.

\section{Kesimpulan}

Mendapatkan vaksin pada masa pandemi covid 19 saat ini adalah merupakan hak warga negara, dan menjadi kewajiban negara untuk memenuhinya. Hanya saja masyarakat memerlukan edukasi akan pentingnya pemberian vaksin ini, mengingat belum semua masyarakat kita mengetahui dan memahami bahwa vaksin ini adalah sebagai upaya untuk menurunkan angka kematian akibat covid 19.

Tentu saja, pemerintah melalui kementrian kesehatan republik indonesia berkewajiban menjamin bahwa vaksin 
yang diberikan sesuai dengan standar mutu dan kualitas kesehatan, sehingga pemberian vaksin bukan hanya formalitas tetapi upaya maksimal pemerintah untuk rakyatnya. Sebagaimana telah disampaikan oleh Presiden Jokowi, yang menugaskan Menteri Kesehatan (Menkes) Republik Indonesia agar mencabut, Peraturan Menteri (Permen) Kesehatan Republik Indonesia Nomor Sembilan Belas tahun 2021 dan menyatakan kepada semua warga negara Republik Indonesia bahwa Vaksin Covid-19 adalah gratis.

Sebagai penutup tulisan ini, seyogyanya Negara atas nama pemerintah pusat untuk melakukan optimalisasi kinerja terbaik memberikan layanan kesehatan kepada masyarakat dimana saja, termasuk vaksinasi covid 19, dengan adil, terukur dan tidak diskriminatif melalui Pemerintah Propinsi / Kabupaten / Kota serta Satgas (Satuan Tugas Penanganan) pandemi Covid-19 yang ada.

\section{Daftar Pustaka}

Guritno, T. (2021). UPDATE: Total 3,4 Juta Kasus Covid-19 di Indonesia, Angka Kematian Masih Tinggi Halaman all Kompas.com. https://nasional.kompas.com/read/2021/08/01/0 7015931/update-total-34-juta-kasus-covid-19-diindonesia-angka-kematian-masih-tinggi?page $=$ all

Hak Cipta dan Hak Penerbitan dilindungi Undang-undang. (n.d.).

Peraturan Menteri Kesehatan Republik Indonesia Nomor 10 Tahun 2021 - Regulasi / Covid19.go.id. (n.d.). Retrieved August 21, 2021, from https://covid19.go.id/p/regulasi/peraturanmenteri-kesehatan-republik-indonesia-nomor-10tahun-2021 
UNDANG UNDANG REPUBLIK INDONESIA. 


\section{Transformasi Dunia \\ Pendjalikan dalam Upaya \\ PERिCEPGTAR

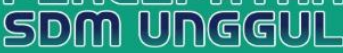

T

idak dapat dipungkiri bahwa COVID-19 membawa kita ke dalam era VUCA (volatility, uncertainty, complexity, ambiguity). VUCA adalah sebuah kondisi dimana terjadi perubahan cepat (Volatile) yang penuh ketidakpastian (Uncertainty), dengan segala permasalahan yang kompleks (Complexity), hingga pada akhirnya membuat semua pihak ragu mengambil keputusan (Ambiguity). Banyak riset menunjukkan bahwa kunci bertahan hidup dalam era VUCA ini adalah memiliki sikap adaptif dan kolaboratif. Setiap lapisan sosial, mulai dari individu hingga negara, harus dapat menyesuaikan diri terhadap perubahan serta mampu melibatkan kolaborasi berbagai sektor untuk mendapatkan solusi yang pendekatan berpusat pada manusia. Salah satu kolaborasi yang memegang peranan penting dalam penanganan COVID-19 adalah antara pemerintah dengan para peneliti dan akademisi.

Kehadiran buku bunga rampai ini dapat menjadi salah satu inspirasi bagi akademisi dan peneliti lainnya untuk terus menyoroti dampak COVID-19 dan dinamika yang terjadi di lapangan. Semoga karya tulis ini dapat menjadi pemantik bagi para akademisi dan peneliti untuk menerbitkan publikasi yang sangat bermanfaat bagi masyarakat luas.

\section{Akademia Pustaka}

Perum. BMW Madani Kavling 16, Tulungagung

https://akademiapustaka.com/

@ redaksi.akademia.pustaka@gmail.com

f) @redaksi.akademia.pustaka

0]@akademiapustaka

081216178398

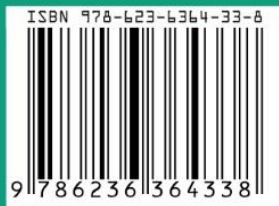

